Programa de Pós-Graduação em Antropologia Social

Faculdade de Filosofia, Letras e Ciências Humanas

Universidade de São Paulo

Tese para obtenção do título de Doutor

\title{
Controlando o poder de matar uma leitura antropológica do Tribunal do Júri - ritual lúdico e teatralizado -
}

Ana Lúcia Pastore Schritzmeyer

Profa . Orientadora Dra . Paula Montero

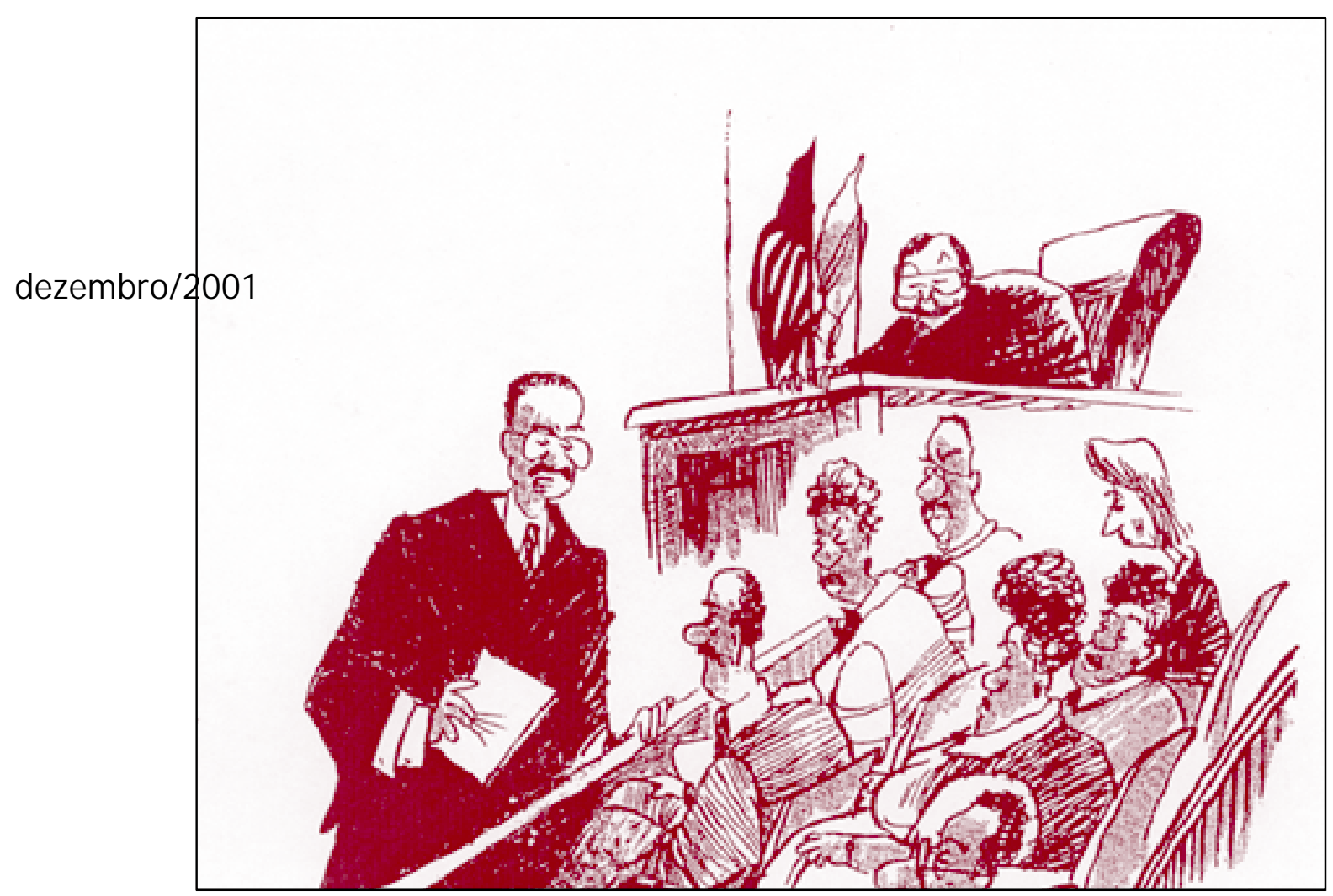


RESUMO

Esta tese apresenta uma etnografia de sessões de julgamentos de homicídio realizadas entre 1997 e 2001, nos cinco Tribunais do Júri da cidade de São Paulo, sendo quatro os conceitoschave que a orientam: jogo, ritual, drama e texto.

A principal conclusão é a de que esses julgamentos baseiam-se na manipulação de imagens relativas a dois poderes fundamentais em todo e qualquer grupo social: o de um indivíduo matar outro e o de instituições sociais controlarem tal faculdade individual. O que está em jogo e em cena, no Júri, mais do que a vida e a morte de indivíduos, é a própria sobrevivência do grupo. Dependendo de como as mortes são textualizadas e contextualizadas, transformadas em imagens e encenadas, o poder individual de matar é considerado socialmente legítimo ou ilegítimo.

Um dos principais objetivos do trabalho foi, portanto, captar quais valores estruturam essa "imaginação social das mortes" e, consequentemente, como o próprio grupo regula a convivência de seus membros e a sua sobrevivência.

Os participantes do Júri, ao darem expressão às imagens desses poderes, através de discursos, expressões e decisões, criam e recriam o mundo da cultura sobre o da natureza. Regras morais, sociais e econômicas arrancam a morte de sua esfera meramente natural e transformam na em metáfora de dramas da vida: vizinhança, parentesco, amor, traição, trabalho, desemprego, tensões do tráfico de drogas e de armas. Cada sessão de Júri é um teste desse mundo das regras, ao qual a cultura é submetida e através do qual ela submete os envolvidos.

O Júri tem um caráter lúdico porque as principais características de qualquer jogo estão nele presentes. Trata-se de uma atividade consciente, exterior à vida habitual e que, enquanto ocorre, absorve os jogadores de maneira intensa. É praticada dentro de limites espaciais e temporais próprios, segundo certas regras. Geralmente, promove a formação de grupos que tendem a rodear-se de segredo e a sublinhar sua diferença em relação ao resto do mundo. Além disso, há uma transformação da realidade em imagens. Personagens e dramas são criados e apresentados aos jurados, em duas versões básicas - a da acusação e a da defesa -, com vistas a que, no silêncio imposto a cada um, eles se identifiquem com a versão que lhes parecer mais verossímil e dêem seu veredicto. É um jogo de persuasão.

O caráter ritual e cerimonial do Júri reside nas ações ordenadas - falas, gestos, expressões -, de natureza predominantemente simbólica, que se desenvolvem em momentos apropriados das sessões e inspiram atitudes de lealdade, respeito e reverência a valores que se materializam nos votos dos jurados. Tais ações transcendem o acontecimento narrado nos autos e alcançam dramas básicos da existência humana.

Por serem o sistema de justiça criminal e, em seu interior, o Júri, sistemas de poder, eles produzem efeitos que se comparam às ilusões criadas pelo teatro, uma vez que a arte de governar e a arte cênica são inseparáveis. Durante os julgamentos, juiz, promotor, defensor e jurados dividem a posição de "príncipes". Enquanto o primeiro reina soberano e aparentemente neutro, o segundo acusa veementemente, o terceiro protege e os demais decidem, em silêncio meditativo. Como um deus que se quadriparte e com isso se fortalece, a encenação de julgar dramas de vida e morte tem como um de seus resultados mais marcantes sacralizar a instituição "Justiça" e revigorar a etiqueta e a estética sociais.

Podendo ser lidas como um texto literário, cujas palavras e expressões principais advêm de um vocabulário de sentimento, as sessões relatam, metaforicamente, a violência de viver e morrer e as tentativas de se lidar com esse drama. 


\section{RÉSUMÉ}

Cette thèse présente une ethnographie de plusieurs séances de jugement de meurtre auxquelles on a assisté, entre 1997 et 2001, dans les cinq Cours d'Assises (Tribunais do Júri) de la Ville de São Paulo, Brésil. Elle est orientée par quatre concepts-clé: jeu, rituel, drame et texte.

La principale conclusion à laquelle on arrive est que ces jugements se fondent sur la manipulation d'images relatives à deux pouvoirs fondementaux dans n'importe quel groupe social: celui qui permet à un individu d'en tuer un autre et celui qui autorise les institutions sociales à contrôler cette faculte individuelle. Par là est mise en jeu et en scène, dans le Jury, la survie ellemême du groupe, bien davantage que la vie et la mort des individus. Le pouvoir individuel de tuer sera considéré légitime ou illégitime selon le mode par lequel les morts deviennent texte et acquièrent un contexte, selon la manière par laquelle ils sont convertis en images et mis en scène.

L'un des principaux buts du travail a donc été de saisir les valeurs qui structurent cette "imagination sociale des morts" et, par conséquent, de comprendre comment le groupe lui -même règle la coexistence de ses membres aussi bien que sa survie en tant que collectif.

Lorsqu'ils rendent les images de ces pouvoirs, par leurs discours, expressions et décisions, les hommes et les femmes qui prennent part au Jury créent et recréent le monde de la culture audessus de celui de la nature. Des règles morales, sociales et économiques arrachent la mort à sa sphère seulement naturelle et en font la métaphore de certains drames de la vie: le voisinage, la parenté, l'amour, la trahison, le travail, le chômage, les tensions du trafic de drogues et d'armes. Chaque séance des assises met à l'épreuve ce monde des règles, auquel la culture se soumet et par le biais duquel elle soumet les personnes concernées.

Le Jury a un caractère ludique parce qu'il rassemble les principaux traits de n'importe quel jeu. II s'agit d'une activité consciente, extérieure à la vie de tous les jours et qui, tant qu'elle a lieu, absorbe intensément les joueurs. Elle est pratiquée, d'après certaines règles, à l'intérieur de certaines limites spaciales et temporelles tout à fait siennes. D'ordinaire le Jury mène à la formation de groupes qui tendent à s'entourer d'un certain secret et à souligner leur différence vis-à-vis du reste du monde. Le Jury est également l'occasion d'une conversion de la réalité en images. Des personnages et des drames sont créés et présentés aux jurés, en deux versions de base - celle de l'accusation et celle de la défense - dans le but que, dans le silence imposé aux jurés, ils s'identifieront à la version qui leur paraîtra la plus vraisemblable et que par là ils donnent leur verdict. C'est un jeu de.persuasion.

Le caractère rituel et cérémoniel du Jury se tient dans des actes ordonnés - des discours, des gestes, des expressions en général - de nature surtout symbolique, qui se produisent à certains moments des séances et qui inspirent des attitudes de loyauté, de respect et de révérence à des valeurs qui se matérialisent dans le vote des jurés. De tels actes transcendent l'événement rapporté dans les actes du procès et touchent des drames fondementaux de l'existence humaine.

Du fait que le système de la justice criminel - et à son intérieur le Jury - constituent des systèmes de pouvoir, et qu'on ne peut séparer l'art de gouverner et l'art scénique, ils produisent des effets qui se comparent aux illusions créées par le théâtre. Lors des jugements, le juge, le procureur, l'avocat de défense et les jurés se partagent le rôle du prince. Le premier règne en tant que souverain et dans une apparence de neutralité, le deuxième accuse avec véhémence, le troisième protège l'accusé et les derniers décident, dans un silence méditatif. Comme un dieu qui se scinde en quatre et par là se renforce, la mise en scène des jugements de vie et de mort a pour un de ses effets les plus frappants de sacraliser l'institution "Justice" et de redonner vigueur à l'étiquette et à l'esthétique sociales.

Les séances - qui peuvent aussi être lues comme un texte littéraire, dont les paroles et les expressions principales proviennent d'un vocabulaire de sentiment - rapportent, métaphoriquement, la violence de vivre et de tuer de même que certains moyens par lesquels on essaie de travailler ce drame.

\footnotetext{
* - versão de Renato Janine Ribeiro
} 


\section{ABSTRACT}

This Ph.D. dissertation presents an ethnography of homicide-judgement sessions which took place between 1997 and 2001 in five jury courts existing in the city of São Paulo, Brazil, between 1997 and 2001. The ethnography will be oriented by four key concepts: game, ritual, drama and text.

The major conclusion is that the judgments are based on a manipulation of images referred to two powers which are fundamental in each and every social group: the power of one individual to kill another, and the power of social institutions to control that individual faculty. More than the individuals' lives and deaths, what really matters in the jury is the group's own survival. Depending on how deaths are textualized and contextualized, transformed into images and staged, the individual power of killing is considered socially legitimate or illegitimate.

One of the main aims of this work is, thus, to apprehend which values structure that "social imagination of the deaths" and, consequently, how the group itself regulates sociability between its members and its survival as a group.

By expressing the images of these powers through speech, expressions and decisions, those who take part in the jury create and recreate the world of culture in the world of nature. Moral, social and economic rules dislocate death from its merely natural sphere and turn it into a metaphor of life dramas: neighborhood, kinship, love, treachery, labor, unemployment, the tensions of drug and weapon dealing. Each jury session is a test for this world of rules to which culture is submitted and through which culture submits the involved individuals.

The jury has a ludic character because it contains the main characteristics of any game. It is a conscious activity, exterior to habitual life, and which, as long as it lasts, intensely absorbs the players. It is practiced inside its own spatial and temporal limits, following definite rules. In general it promotes the formation of groups which tend to involve themselves with secrets and to emphasize their difference from the rest of the world. Moreover there is a transformation of reality into images. Amidst the silence imposed to each juror at a jury session, characters and dramas are created and presented to them in two basic versions - of accusation and of defense - in order that they can identify themselves with the version that seems more creditable and then give their verdict. It is a game of persuasion.

The ritual and ceremonial character of the jury lays in the ordered actions - speech, gestures, expressions - of predominantly symbolic nature which take place in proper moments during the sessions and inspire attitudes of loyalty, respect and reverence towards values that materialize themselves in the vote of the jury members. These actions transcend the happening narrated in the judicial acts, encompassing basic dramas of human existence.

Since both the system of criminal justice and, inside this system, the jury are systems of power, they produce effects comparable to the illusions created by theater. The arts of governing and of staging are inseparable. During the judgments the judge, the district attorney, the defense lawyer and the jurors share the position of "princes". While the judge reigns as a sovereign and in an apparent neutrality, the D.A. vehemently accuses, the lawyer protects and the jurors decide, immersed in a meditative silence. One of the most impressive results of staging the judgment of dramas related to life and deathis that, like a god which splits -himself into four and thus strengthens himself, the institution "Justice" is sacralized, and social etiquette and aesthetics are reinvigorated.

The jury sessions can be read as a literary text whose main words and expressions derive from a vocabulary of feeling. In a methaphorical way they narrate the violence of living and dying, and men's efforts to deal with this drama.

\footnotetext{
* - versão de Fraya Frehse
} 
Para Rafael, com gratidão por ter vindo, e com um amor que cabe no colo, embora maior que o mundo.

Em memória de Santana - Antonia Maria de Sousa Silva (1955-2001) babá de Rafael, que, com imensa generosidade, cuidou de nós dois, até seu último minuto. 


\section{AGRADECIMENTOS}

Graças a vários fatores e apesar de muitos outros, esta tese foi concebida, gerada e, finalmente, desprende-se de mim. A partir de agora, como num passe de mágica, ela perde as dimensões gigantescas que ganhou em minha vida e passa a integrar o imenso conjunto de esforços voltados para o conhecimento do ser humano. Se como componente desse conjunto, ela tiver algum brilho, isto se deve, em grande parte, às pessoas que passo a nomear e, se não o tiver, é porque fui egoísta e só absorvi a luz com que elas iluminaram meu caminho.

Em primeiro lugar, um agradecimento especial a meu pai, Mário Adolpho Schritzmeyer que, do alto de seus 83 anos, além de contemplar o tempo e a vida, acompanha minha trajetória e não mede esforços para ajudar-me.

Em ordem alfabética - pois sobrepor os nomes tornaria-os ilegíveis - , alguns Amigos, de todas as horas e, especialmente, de algumas: Adriana Ostermayer, Alba Cantanhede França, Ana Maria Ferraz Negreiros, Annie Dyetmann, Celso Fernandes Campilongo, Cláudia Márcia Costa, Cléa Morgado Dias Lopes, Cristina Eiko Sakai, Céci Gikovate, Eliana Ramalho Campilongo, Eneida Haddad, Fernando Herren Aguillar, Fernando Proença de Gouveia, Fraya Frehse e família, Guiomar Schritzmeyer Sampaio, Iris Regina Fernandes Poffo, Júnia de Moraes Nogueira Ramalho, Jacqueline Sinhoretto, Lígia Maria Daher Gonçalves, Luci Gatti Pietrocolla, Marialice Nogueira Emboava, Marianna Correia, Mônica da Silva Stella, Mônica Duarte Dantas, Paula Morgado Dias Lopes, Renato Sérgio de Lima, Rita de Cássia Barros Dias, Sílvia Pimentel, Therezinha Janine Ribeiro, Valéria Pandjiarjian e Wânia Pasinato.

Ana Laura Prates, com seu saber psicanalítico, propiciou-me a descoberta de caminhos internos que permitiram-me, com mais tranqüilidade, prazer e esperança percorrer os meses finais de redação desta tese.

Não fossem os comentários redirecionadores e estimulantes dos professores componentes da banca de qualificação - Maria Lúcia Montes e Sérgio Adorno -, assim como a orientação potencializadora de Paula Montero, provavelmente, eu não teria distinguido o caule principal deste trabalho e feito com que ele crescesse. As obliqüidades que restaram revelam limites e limitações que, hoje, são meus e, amanhã, quem sabe não mais serão.

Renato Janine Ribeiro contribuiu com importantes sugestões bibliográficas e, com gentil companheirismo, imprimiu, leu e revisou várias das versões de cada capítulo. 
Meus colegas de militância na luta cotidiana pela defesa e disseminação dos Direitos Humanos estimularam -me e compreenderam porque, durante estes últimos anos, vivi com a cabeça "no mundo do Júri". Agradeço-lhes, nomeando nossos pontos de encontro: NEV-USP - Núcleo de Estudos da Violência da Universidade de São Paulo-, FSEADE - Fundação Sistema Estadual de Análise de Dados -, IBCCRIM — Instituto Brasileiro de Ciências Criminais -, CEPEDISA - Centro de Estudos de Direito Sanitário da Faculdade de Saúde Pública da Universidade de São Paulo —, Secretaria da Segurança Pública do Estado de São Paulo e CLADEM-BRASIL - Comitê LatinoAmericano e do Caribe para a Defesa dos Direitos da Mulher.

Vários alunos e colegas professores acompanharam o desenvolvimento deste trabalho, através de debates nos quais eu apresentava-Ihes meus problemas de pesquisa e com a pesquisa. Na impossibilidade de nomeá-los, todos, seguem menções aos dois principais cursos e instituições em que estivemos juntos: Curso de Especialização em Direito Sanitário da Faculdade de Saúde Pública da Universidade de São Paulo e Curso de Graduação em Direito da Faculdade de Direito da Universidade São Judas Tadeu.

Através do Juiz Sérgio Mazina Martins, do Promotor Carlos Roberto Marangoni Talarico, do defensor Ricardo Constante Soares e da oficial de justiça Suzana Elizabeth Grassi Medeiros, todos do $1^{\circ}$ Tribunal do Júri de São Paulo, gostaria de agradecer aos demais juízes, promotores, advogados e funcionários desse e dos outros quatro Tribunais, pela maneira respeitosa e prestativa com que, ao saberem de meu trabalho, auxiliaram-me e incentivaram-me.

Agradeço, ainda, ao CNPq - Conselho Nacional de Apoio à Pesquisa - pela bolsa de estudos que me concedeu durante os quatro primeiros anos de doutorado.

Por fim, embora eu já tenha dedicado esta tese a meu filho, Rafael, gostaria de incluí-lo nestes agradecimentos, pois todas as muitas vezes em que ele interrompeu meu trabalho, pude, depois, retomá-lo com a doce sensação de que aquilo que produzimos com amor jamais é em vão. 
"É possível negar (...) quase todas as abstrações: a justiça, a beleza, a verdade, o bem, Deus (...). mas não o jogo. Mas reconhecer o jogo é forçosamente, reconhecer o espírito, pois o jogo (...) não é material. (...). A própria existência do jogo é uma confirmação permanente da natureza supralógica da situação humana. Se os animais são capazes de brincar, é porque são alguma coisa mais do que simples seres mecânicos. Se brincamos e jogamos, e temos consciência disso, é porque somos mais do que simples seres racionais (...)."

(Huizinga, 1980: 6)

"Os grandes julgamentos (...) levam a dramatização a seu mais alto grau de intensidade. Eles impõem uma encenação, um cenário, papéis, instâncias secretas e violências, revelações e efeitos de surpresa que levam geralmente à confissão do acusado. Recorrem ao extraordinário, inclusive no arranjo do cerimonial judiciário. São calcados em uma lógica implacável, mas seu funcionamento provoca emoções - desde a reprovação até a cólera e o ódio populares. (...) a meta do drama é a morte física ou moral daqueles que o poder acusa em nome da salvaguarda da forma e dos valores supremos da sociedade."

(Balandier, 1982:10) 


\section{SUMÁRIO}

Considerações Iniciais

1. Júri-jogo

Introdução

Caráter lúdico da cultura e do Júri

Algumas características dos jogos, em geral, dos jogos sociais, em particular, e do Júri, em especial Jogos voluntários e "obrigatórios"

Difícil interrupção

Tempo e espaço artificiais: "círculo mágico" Arrebatamento, tensão, competição, futilidade e êxtase Acordos de "bastidores" Cria ordem e é ordem

Belo

Comunidade de jogadores X "outros"

Festa

Sistema de crenças

2. Jogo Veredicto

Introdução

Apresentação do jogo: ilustração e dizeres da caixa

1) instruções preliminares

2) objetivos

59

3) número de jogadores 60

4) componentes do jogo: tabuleiro-plenário, cartas, peças e outras variáveis 63

5) preparação do jogo 6) como jogar 66 71

7) vencedor do jogo 76

8) observações

Introdução

Onde a vida social se substantiva e se materializa

O tempo do e no Júri: rito de passagem 
Uma "sociologia dramatizada" ou uma "dramatização sociologizada"

Poder e drama

Retórica do poder

Uma faceta burlesca: a desordem garantindo a ordem

Drama, melodrama ou tragédia? 139

Etiqueta do e no Júri 141

Palco e platéia ou atores e público 146

5. Uma leitura antropológica do Tribunal do Júri

6. Tese: ritual lúdico e teatralizado

Introdução

"Antecedentes acadêmicos"

Um processo de lapidação

Trabalho de campo e reflexões teórico-metodológicas: recíprocas influências

\section{Anexos}




\section{CONSIDERAÇÕES INICIAIS}

Dentre as várias pessoas que entrevistei, no decorrer deste trabalho, poucas dirigiram-me perguntas, seja antes, durante ou depois das entrevistas. Mas, certa vez, uma jurada formulou-me a seguinte: "Desculpe minha ignorância, filha, mas o que, exatamente, é uma tese de doutorado em Antropologia sobre o Júri?" ${ }^{1}$

Essa mulher de 66 anos, negra, funcionária pública aposentada, chamada Matilde, que mais parecia saída da ala das baianas de uma escola de samba, tamanha era sua presença alegre e forte, fez-me pensar, de imediato, que eu estava longe de uma Antropologia compartilhada, pois, na maioria das entrevistas que eu até então realizara, inclusive e principalmente com profissionais do Direito, eu abordara os entrevistados apresentando-me, rapidamente, e logo partindo para uma conversa aparentemente dialogada, mas não a ponto de eles sentirem-se à vontade para me devolver perguntas.

Aquela jurada, contudo, era diferente: combinava um ar altivo com uma expressão labial sorridente. Não aparentava estar preocupada em mostrar-se "sábia como uma juíza", mas creio que era assim que se sentia, tanto que começou sua pergunta com um "Desculpe minha ignorância", para, em seguida, chamar-me de "filha" e colocar-me, simbolicamente, em seu grande colo.

A resposta completa à pergunta que ela me formulou, em última análise, são as mais de 200 páginas deste trabalho, as quais, em meus sonhos, vejo lidas, além de pelos examinadores e amigos, também por meus entrevistados. Lembro-me de, na ocasião da entrevista com Dona Matilde, ter dito a ela, meio em tom de brincadeira, que era impossível definir exatamente o que é uma tese de doutorado em Antropologia sobre o Júri, pois tese, doutorado, Antropologia e Júri são termos por demais complicados para caberem em definições exatas. Tentei, todavia, explicar-Ihe que eu analisava o Júri enquanto um jogo, um ritual, um teatro, uma espécie de texto literário através do qual são relatados modos legítimos e ilegítimos de matar e viver nesta cidade. Lembro-me de ela dizer, depois dessa explicação, balançando a cabeça com expressão compenetrada: "É... A gente finge que a vida é mais simples do que é, mas é só fingimento, filha. Todo mundo, na verdade, sabe que isso aqui [apontou para o espaço do fórum], o que tá lá fora [na rua] e,

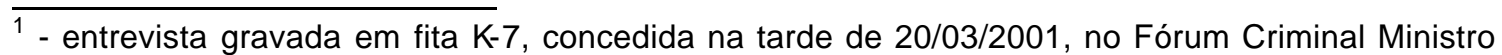
Mário Guimarães, Barra Funda. 
principalmente, o que tá aqui dentro [apontou para o seu e o meu coração] é complicado. Ainda bem, né! Assim vocês têm o que estudar [rimos, nós duas]."

É, Dona Matilde, a senhora mesma respondeu a sua pergunta. Esta tese é "exatamente" isso: meu modo de recortar o que já foi recortado por outros, tanto do "mundo de fora" quanto do "mundo dos corações", e acabou chegando aos plenários do Júri. Antropólogos recortam recortes e, com isso, de certa forma, também simplificam o que não tem limites definidos. Mas se não fosse assim, não existiria Antropologia, nem ciência, nem teses de doutorado.

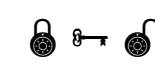

Noutra ocasião, antes do início de um julgamento, fui apresentada da seguinte forma pelo juiz ao promotor, ao defensor e à escrevente que atuariam naquela sessão²: "Esta é a $\mathrm{Dr}^{2}$ Ana Lúcia que, além de ser nossa colega, advogada, também é socióloga, ou melhor, antropóloga. Enfim, ela está escrevendo sua tese de doutorado sobre o Júri e por isso tem vindo aqui acompanhar várias sessões. Provavelmente, perceberá coisas que fazemos e que nós mesmos nem imaginamos...".

Todos me olharam com uma simpatia desconfiada.

"E o que a Sr. ${ }^{a}$ já está percebendo, Dr. ${ }^{\text {a }}$ ? Pode nos contar ou é segredo?", perguntou-me o promotor. Respondi-Ihe: "Há várias maneiras de perceber uma situação, Dr.: de dentro, de fora. Vocês estão dentro do Júri e eu fora. Interessa-me tanto o que vocês percebem, o que os jurados percebem, os funcionários, quanto os assistentes e eu mesma. Por enquanto, estou só observando, entrevistando pessoas..."

E o juiz tornou a falar: "Ela está sendo humilde, para não nos intimidar. Um antropólogo é uma espécie de psicólogo. Quando observa já está interpretando e percebendo algo mais, não é mesmo?"

Foi então a minha vez de ficar meio desconcertada, e a conversa interrompeu-se, pois o julgamento começaria.

Essa maneira de eu ser apresentada, de me ser conferida uma identidade que, simultaneamente, igualava-me aos operadores técnicos - advogada - e diferenciava-me deles - socióloga, ou melhor, antropóloga - e mesmo o modo como respondi ao promotor não saíram de minha lembrança, bem como a pergunta formulada por Dona Matilde.

Nos dois casos, registrei, em meu diário de campo, reflexões sobre a relação sujeito-objeto, especificamente sobre minha postura que, certamente, causava interferências nas situações observadas, sem contar o peso que as hipóteses e 
pressupostos dos quais eu partia estavam tendo na condução do trabalho. Contudo, o que mais me inquietou foi a comparação que o juiz fez entre antropólogos e psicólogos.

Ele distinguiu a Antropologia da Sociologia e aproximou a primeira da Psicologia. Penso que mais próxima ainda ela está da Psicanálise e da Filosofia, pois essas três áreas do conhecimento voltam-se para a busca de significações. Nelas, o que mais importa é, a partir de episódios, até isolados, refletir sobre seus sentidos freqüentemente múltiplos, construídos, atribuídos e distribuídos em interações complexas.

Noutra oportunidade em que reencontrei o mesmo juiz, ele me pediu que the explicasse a diferença entre sociólogos e antropólogos. Fui meio simplista e comentei que sociólogos, provavelmente, não considerariam o "último dos moicanos" um objeto de estudo tão relevante quanto antropólogos, pois por ser o último, não haveria mais uma sociedade a observar e a oferecer parâmetros de valores e comportamentos. Já antropólogos estudariam detidamente esse indivíduo, por acreditarem que ele carregaria consigo experiências significativas da extinta tribo, mesmo que fosse um "último moicano desviante". O juiz, sorrindo, contra-argumentou: "Seja como for, acho que tanto antropólogos quanto sociólogos têm um modo interessante de abordar o mundo. Nós, do Direito, seremos sempre seus moicanos, jamais o contrário".

Esse diálogo levou-me a refletir bastante a respeito de para quem e para que escrevo esta tese. Para antropólogos? Sociólogos? Profissionais do Direito? Também para leigos interessados em Júri? Para todos esses? Que contribuição ela pode dar para esses possíveis leitores?

Para interessar a antropólogos, sei que não basta uma tese que demonstre, genericamente, com base na literatura predominante da área e com exemplos retirados do material empírico, que o Júri é um jogo, um ritual, uma dramatização e um texto cuja lógica e significados podem ser lidos e interpretados. Qualquer antropólogo, provavelmente, concorde com isso sem necessitar de uma tese para convencer-se. Contudo, é de se esperar que a maioria dos profissionais do Direito demande subsídios teóricos e empíricos para averiguar essas afirmações. Sociólogos, por sua vez, possivelmente, perguntem-se que pontes podem ser feitas entre análises qualitativas e conclusões mais amplas a respeito do papel desempenhado pelo Júri na administração dos conflitos sociais e na socialização de indivíduos, ou quais os perfis e trajetórias

2 - 15/08/2001, 12h, sala secreta do Plenário 7, do $1^{0}$ Tribunal do Júri (Barra Funda). 
socioculturais de jurados e operadores técnicos do Júri, bem como suas conseqüências quanto ao acesso e à distribuição da justiça.

Enfim, uma primeira constatação a que cheguei foi a de que, ao menos para fazer do texto final desta tese uma Antropologia a ser compartilhada com outros antropólogos, sociólogos, profissionais do Direito e leigos interessados pelo tema, eu teria de enfrentar um desafio: manter um certo "didatismo antropológico" — familiarizando colegas do Direito e leigos em Antropologia com certos conceitos e análises relativos a jogos, rituais e dramas - e, ao mesmo tempo, um certo "didatismo jurídico" - familiarizando colegas antropólogos e leigos em Direito com alguns detalhes técnicos e doutrinários do Júri. Busquei fazer isso e ainda justificar a Antropologia como a via mais adequada para pensar o sistema de valores que dá vida e é alimentado pelo jogo, pelo ritual, pelo drama e pelo texto dos julgamentos do Júri.

Tendo esse conjunto de desafios em mente, nos capítulos 1 e 2, está em questão que tipo de jogo é o do Júri: sua lógica, seus elementos, características do espaço e tempo em que se desenvolve e de interações entre jogadores. Ao contrário do que se costuma comentar, a pesquisa realizada demonstrou que não somente promotores e defensores jogam para persuadir jurados. Esses últimos, juízes, assistentes e o próprio réu também se valem de uma linguagem persuasiva, não apenas verbal, caracterizando, assim, o jogo do Júri como um sistema de persuasões.

No capítulo 3, está em discussão o caráter ritual do Júri: os plenários enquanto espaços simbólicos privilegiados para a percepção, produção e reprodução de valores em torno da legitimidade ou ilegitimidade de se matar na cidade de São Paulo. Tais valores, normalmente inconscientes, reelaboram-se e emergem articulados nas situações de julgamento.

O debate em torno da teatralidade do e no Júri é objeto do capítulo 4 . Nele está apontada a estreita relação entre a arte do governo e a da cena. Mas, assim como nos capítulos anteriores, a retomada genérica de conceitos como teatrocracia, poder e drama, serve apenas de base para a interpretação de passagens de julgamentos em que os vários "atores" evidenciam uma luta pela conquista e/ou manutenção do uso legítimo do poder de matar.

No capítulo 5, o Júri é reapresentado como um texto imaginativo — pleno de imagens baseadas em sentimentos -, construído a partir de "materiais sociais". A pesquisa de campo permitiu acessar algumas dessas imagens, pensar como e por quem 
são construídas, de quais "materiais sociais" seus construtores se servem e para que finalidades cognitivas são utilizadas. Um "caso para pensar" também está descrito, nesse capítulo. Relatado, do começo ao fim, ele é apresentado enquanto situação, ao mesmo tempo, particular - caracterizada por pessoas, espaços, tempos e ritmos compostos de forma única - e universal - elaborada a partir de algo que vai além de especificidades, pois pertence a um sistema de valores que, em alguma dimensão, é compartilhado. Embora esse julgamento não retrate "a" maneira de "a sociedade paulistana" lidar com o uso legítimo do poder de matar — até porque não há uma só maneira e porque é muito difícil falar dessa "sociedade" —, ele permite uma reflexão sobre a construção legallegítima desse poder.

No $6^{\circ}$ e último capítulo, que tradicionalmente poderia ser chamado de "metodológico", a própria elaboração, execução e apresentação desta tese são analisadas também a partir dos conceitos de jogo, ritual e drama. As principais alterações pelas quais passou o projeto original até a entrega da tese - especialmente antes e depois do exame de qualificação - embasam reflexões sobre o caráter lúdico-ritualístico do exercício intelectual-acadêmico. Emoções envolvidas na construção do texto e a possibilidade de também lê-lo como uma "estrutura simbólica", cujos limites transcendem o tema e a problemática óbvios, permitem pensar a dramaticidade envolvida na elaboração deste tipo de trabalho.

Nas “Considerações finais", tento responder à pergunta que vários interlocutores, especialmente da área jurídica — fizeram-me ao longo do doutorado: "Afinal, depois de tanta análise, você acha que o Júri deve ou não continuar existindo no Brasil? Elaboro uma resposta antropológica para uma pergunta não antropológica e, portanto, posso causar frustrações.

$$
\text { 우요 }
$$

Enfim, voltando à pergunta de Dona Matilde e lembrando Lévi-Strauss, esta tese de doutorado em Antropologia sobre o Júri resultou de escolhas cujas motivações não são apenas científicas. "Inicialmente, escolhemos por acaso, porque as circunstâncias de nossa carreira levaram-nos em tal ou tal dreção, e depois também por razões que dizem respeito a afinidades ou antipatias pessoais. (...) Já se disse muitas vezes - não sei se é geralmente exato, mas certamente é verdade para muitos de nós - que o motivo que nos levou à etnologia é uma dificuldade de nos adaptarmos ao meio social no qual nascemos." (Charbonnier, 1989: 13, 1415). 
Para mim, esta tese é "exatamente" isso: o resultado de circunstâncias profissionais, de razões pessoais e, especialmente, do fato de que encontro na Antropologia a posição mais confortável para atuar na área jurídica.

$$
\text { (3) \& } 8
$$


capítulo 1

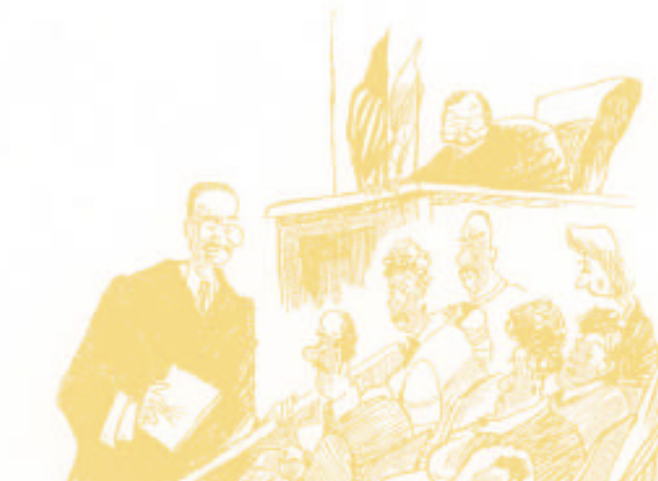




\section{JÚRI-JOGO}

\section{- Introdução}

Há mais de 60 anos - exatamente em 15 de junho de 1938 —, o historiador holandês Johan Huizinga ${ }^{1}$ concluía o prefácio de seu livro Homo ludens: o jogo como elemento da cultura. Nessas páginas introdutórias, explica que, desde 1903, quando começou a desenvolver a tese "(...) de que é no jogo e pelo jogo que a civilização surge e se desenvolve", seus interlocutores equivocavam-se achando que sua proposta apresentava o jogo como elemento na cultura e não como elemento da cultura. Para explicar por que se tratava da segunda expressão e não da primeira, ou seja, por que o conceito de jogo integra o de cultura e não é apenas uma manifestação dela, o livro Homo ludens foi escrito. ${ }^{2}$

Ainda no prefácio, Huizinga comenta: "Se eu quisesse resumir meus argumentos sob a forma de teses, uma destas seria que a antropologia e as ciências a ela ligadas têm, até hoje, prestado muito pouca atenção ao conceito de jogo e à importância fundamental do fator lúdico para a civilização."(Huizinga, 1980: Prefácio, penúltimo §).

De lá para cá, alguns cientistas sociais - talvez não tantos antropólogos quanto Huizinga gostaria - vêm abordando, de diversas maneiras, o conceito de jogo e a importância do fator lúdico na constituição da cultura. Na maioria desses trabalhos, todavia, predominam afirmações de que onde há jogos há dominação, uma vez que eles envolvem poder e constituem arenas de lutas. Em outras palavras, prevalece uma abordagem dos espaços lúdicos, especialmente dos tribunais, enquanto lugares de sujeição.

Neste capítulo, não só apresentaremos o Júri como um jogo que transcende essa sujeição, pois permite a construção de subjetividades e a redefinição de experiências sociais, como argumentaremos porque as sessões de Júri são um ritual de caráter lúdico e agonístico.

\footnotetext{
1 - (1872 - 1945), professor e reitor da Universidade de Leyden (Holanda) e, por ter resistido aos desmandos nazistas, morreu num campo de concentração.

2 - Agradeço ao amigo Osvaldo Humberto Leonardi Ceschin, Professor Doutor do Departamento de Letras Clássicas e Vernáculas da USP, por, há aproximadamente 15 anos, ter me apresentado o livro O Declínio da Idade Média, de Huizinga, e por ter mencionado, naquela ocasião, que, algum dia, eu deveria ler Homo ludens. Ele tinha toda a razão.
} 


\section{- Caráter lúdico da cultura e do Júri}

Segundo Huizinga (1980: cap. 1), várias e divergentes teorias psicológicas e fisiológicas levantam hipóteses, não necessariamente excludentes, porém parciais, ao tentarem definir as funções do jogo. As principais delas apontam -no como:

a) descarga de energia vital superabundante;

b) satisfação de um certo "instinto de imitação";

c) "necessidade" de distensão, após esforço;

d) preparação do jovem para exigências da vida adulta;

e) exercício de autocontrole indispensável ao indivíduo;

f) impulso inato para exercer uma certa faculdade; desejo de dominar e competir;

g) escape para impulsos prejudiciais e/ou compensação de desejos insatisfeitos.

Embora o pressuposto comum a todas essas hipóteses seja importante - o de que "No jogo existe alguma coisa "em jogo" que transcende as necessidades imediatas da vida e confere um sentido à ação. Todo jogo significa alguma coisa." (Huizinga, 1980:3-4) — Huizinga as considera reveladoras de preocupações superficiais, uma vez que elas apontam somente o que o jogo é, em si mesmo, ou o que ele significa para os jogadores. Em sua opinião, é preciso ir além e analisar o caráter "profundamente estético" do jogo, ou seja, o fato de que é em sua intensidade, poder de fascinação e capacidade de excitar "(...) que reside a própria essência e a característica primordial do jogo" (op. cit: 5).

Em outras palavras, onde esgotam-se as abordagens psicológica e biológica dos impulsos e hábitos que condicionam o jogo, começa a teoria de Huizinga, para quem o jogo é fator cultural "significante": "Se (...) o jogo se baseia na manipulação de certas imagens, numa certa "imaginação" da realidade (ou seja, na transformação desta em imagens), nossa preocupação fundamental será, então, captar o valor e o significado dessas imagens e dessa "imaginação." (op. cit: 7).

Partindo desse pressuposto e estendendo-o às sessões de Júri, podemos percebê-las como baseadas na manipulação de imagens relativas à regulamentação do poder de um indivíduo matar outro. Não é esse poder de matar, enquanto ação, que está em jogo, pois ele já foi exercido por alguém sobre alguém. O caráter estético do Júri, sua intensidade, fascínio e excitação residem na construção de julgamentos a respeito das circunstâncias que tornam o uso desse poder legítimo ou ilegítimo. Dependendo de como as mortes s̃o contadas e imaginadas - transformadas em imagens a serem julgadas —, possíveis usos do poder de matar são socialmente 
legitimados ou não. Portanto, captar quais valores e motivações estruturam a legitimação desses usos é perceber como os participantes do Júri regulam não as mortes ocorridas, mas o andamento de suas próprias vidas.

O fundamental, portanto, é entender o valor e o significado das imagens que manipulam as mortes, pois esses pertencem à esfera da cultura e transcendem as necessidades imediatas da vida.

Admitindo, assim, que tais imagens referem-se a um jogo de atribuição de significados ao poder de matar, cabe-nos acrescentar que os atores do Júri, ao expressarem essas imagens, através de seus discursos, gestualidades e decisões, reafirmam o mundo da cultura sobre o da natureza. Um mundo de regras - morais, sociais, econômicas - arranca as mortes de sua esfera meramente natural e transforma-as em metáforas de dramas da vida - vizinhança, parentesco, amor, trabalho, ócio, tráfico de drogas e de armas. Cada sessão de Júri, nesse sentido, é um teste desse "mundo das regras", ao qual a cultura é submetida e através do qual submete os participantes - juízes, promotores, advogados, réus, testemunhas, funcionários e assistentes.

Se quisermos explorar, um pouco mais, essa explicitação de regras culturais durante as sessões de Júri, podemos dizer que seus participantes só são capazes de formulá-las, percebê-las e utilizálas porque já as têm, socialmente, internalizadas. Dãose conta delas e as materializam nos plenários dos Júris porque ali, diante de casos concretos, expõem-se à necessidade de julgar e decidir a vida de acusados de homicídio. Portanto, o que aparentemente criam, na verdade, já existe, pois as regras do jogo do Júri são regras da vida social. O que o Júri permite é uma leitura dessas regras através de argumentações sobre quando e como se pode ou não matar.

\section{- Algumas características dos jogos, em geral, dos jogos sociais, em particular, e do Júri, em especial}

\section{- Jogos voluntários e "obrigatórios"}

Certas características gerais dos jogos (1980: cap. 1) são "boas para pensarmos" a dinâmica de algumas regras sociais que emergem nos plenários do Júri. Uma delas características é o fato de a maioria dos jogos serem atividades voluntárias que, especialmente quando realizadas entre adultos, podem ser adiadas ou suspensas. Contudo, quando ligam-se a noções de obrigação e dever, passando a ter uma função 
culturalmente reconhecida, seja sob a forma de cultos ou de rituais, tornam-se atividades lúdicas necessárias.

As sessões de Júri, por terem a função, culturalmente reconhecida, de fazerem parte de uma instituição de controle da criminalidade, sendo elas, inclusive, legalmente ritualizadas, ligam-se a noções de obrigação e dever. Consequentemente, tornam-se necessárias, não ocorrendo somente quando interessa a seus participantes, tampouco, podendo ser "facilmente" adiadas ou suspensas. Esse caráter obrigatório das sessões, todavia, não significa que juízes, promotores, advogados e até jurados lá estejam apenas para cumprir uma obrigação.

Seguir carreira no Júri e ser jurado voluntário implica, ao menos de início, escolhas baseadas em algum tipo de prazer, tanto que são corriqueiras declarações como as de um promotor: "Quando eu era estudante, acompanhava as sessões e me imaginava nelas. Adoro isto aqui. Não saberia fazer outra coisa. (...). Aqui ocorre algo que me completa."

Outro promotor, ao finalizar a Introdução de seu livro, escreve: “(...) o trabalho apresentado, como não poderia deixar de ser, tem o cacoete do Promotor de Justiça. E talvez tenha mais do que isso (e só compreenderão aqueles que são ou que foram protagonistas do Júri). Possivelmente ele inclua, subjacente, uma declaração de amor."(Trein, 1996: 15).

Vários advogados que dissertam sobre o Júri fazem "declarações de amor" semelhantes: “(...) este livro se faz imprescindível a todos que atuam no Tribunal Popular (Magistrados, Promotores de Justiça, Advogados), bem como estudantes que já sintam paixão por essa maravilhosa instituição." (Prefácio de Roberto Delmanto Júnior ao livro de Almeida, 2001: 14).

Quanto aos jurados, embora os voluntários sejam minoria frente aos compulsoriamente convocados ${ }^{4}$ e apesar de muitos dos mais antigos confidenciarem, em entrevistas, insatisfações e frustrações - por exemplo, com o número de vezes em

\footnotetext{
3 - 15/08/2001, das $12 \mathrm{~h}$ às $16 \mathrm{~h} 45^{\prime}$, Plenário 7 do $1^{\circ}$ Tribunal do Júri (Barra Funda)

4 - Desconheço a existência de algum estudo brasileiro que mensure percentuais recentes de jurados voluntários e dos compulsoriamente convocados, comparando eventuais diferenças entre seus comportamentos e opiniões a respeito do Júri. O trabalho empírico que mais se aproxima dessa questão é uma pesquisa de opinião, realizada nos meses de junho e julho de 1997 , no $3^{\circ}$ Tribunal do Júri de São Paulo, com 574 jurados. Ela apurou que, desse total, 23,17\% estariam dispostos a ser jurados voluntários, $59,76 \%$ não estariam e 14,81\% eram indiferentes. Quanto à remuneração - inexistente - , 48,78\% declararam que ela deveria existir, $34,32 \%$ que não deveria e 15,16\% são-Ihe indiferentes (Nucci, 1999: $330-331$ ). En passant, em alguns textos, há menções ao fato de que a compulsoriedade e a participação não remunerada dos jurados podem ser responsáveis pela má vontade de alguns e, consequentemente, prejudicar os julgamentos. Algumas regras básicas de organização do Júri, inclusive as relativas à escolha de jurados, encontram-se mencionadas e analisadas no próximo capítulo.
} 
que comparecem mas não há sessão ou com o fato de nem sempre serem sorteados para compor o Conselho - , nas falas de quase todos percebe-se um certo orgulho por terem sido escolhidos dentre cidadãos de "notória idoneidade". Aliás, essa expressão do Código de Processo Penal (art. 436) é reiterada, com essas ou palavras análogas, durante as sessões, geralmente quando juízes, promotores e advogados dirigem-se aos jurados para lembrar-Ihes quem são e porque estão ali: "Vossas Excelências estão diante de uma tarefa nada fácil que é a de determinar o destino do réu. Trata-se de um trabalho que lida com dois bens muito preciosos: a liberdade e, principalmente a vida. (...). O que julgarão é se $o$ acusado tirou a vida de outro homem e se, por isso, merece perder a sua liberdade. Mas como Vossas Excelências são cidadãos de notória idoneidade, dignos representantes da sociedade, tenho certeza de que desempenharão bem essa difícil tarefa. ${ }^{5}$.

Enfim, apesar de o Júri, enquanto jogo, ter um caráter predominantemente obrigatório para seus participantes, os principais jogadores - aqui, excluindo-se o réu - sentem alguns prazeres por estarem ali, dentre os quais o de serem considerados e considerarem-se idôneos para julgar e decidir. Portanto, o jogo, em si mesmo, propicia a esses jogadores o prazer de compartilharem uma identidade socialmente reconhecida como "digna", o que, por conseqüência, confere-lhes status.

Disso, decorrem outros prazeres, dentre os quais o de operadores técnicos e jurados ocuparem posições de poder das quais deliberam sobre o uso de outro poder, pois o que decidem é se o réu terá seu poder de matar - aliás, comum a todas as pessoas - controlado por ele mesmo - caso em que será absolvido e, teoricamente, recuperará o status de cidadão "idôneo" - ou se terá esse poder controlado, de perto, pelo sistema de justiça criminal - caso em que será privado de sua liberdade e do status de idôneo. ${ }^{6}$

\footnotetext{
5 - 18/03/1999, das 13h40' às 16h30', Plenário II do $3^{\circ}$ Tribunal do Júri (Santo Amaro). O conceito de notória idoneidade está analisado no próximo capítulo.

6 - No campo das grandes questões éticas, destacase a do controle das paixões pela razão. A literatura filosófico-política, todavia, tem fartamente demonstrado que, sozinha, a razão não efetiva esse controle. Daí os projetos de poder extrapolarem estratégias racionais na tentativa de alcançarem "o espírito", pois esse é um rígido fiscalizador dos "apetites", paixões e desejos humanos (Ribeiro, 1984: cap. 5). Os jurados leigos, talvez, sejam exatamente esses fiscalizadores, não meramente técnico-racionais, do "apetite" de matar. Nessa mesma linha de raciocínio, talvez se possa entender porque réus e prisioneiros "convertidos" a religiões evangélicas são vistos como menos "perigosos" à sociedade: Deus os está controlando. (Essas e outras idéias correlatas estão melhor desenvolvidas nos próximos capítulos).
} 


\section{- Difícil interrupção}

Enquanto os jogos voluntários, especialmente entre adultos, podem ser facilmente adiados ou suspensos, conforme já apontamos, os de caráter obrigatório são de difícil interrupção, exigindo fortes motivos para que não cheguem ao desfecho esperado.

Em relação às sessões de Júri, é sempre muito delicado interrompê-las ou mesmo suspendê-las e impugná-las, antes do anúncio da sentença. Quando isso ocorre, normalmente o juiz respalda-se nas próprias regras formais do jogo - do Código de Processo Penal - para justificar a interrupção e, assim, não desacreditar o jogo e os jogadores.

Para ilustrar essa afirmação, segue uma análise do que determinou a difícil impugnação de uma sessão, quase dez horas depois de iniciada.

Ela começara por volta das 9 horas da manhã. Tratava-se do julgamento de um jovem negro, magro, de apelido "Nenê". Ele teria sido vítima de roubo (um walkman), depois do que, matara o assaltante, auxiliado por outro homem, também apelidado de Nenê. No Júri, durante seu interrogatório, o réu negou a autoria do delito. Várias testemunhas foram chamadas a depor, três das quais delegados de polícia e dois investigadores, pois pairavam dúvidas se o réu teria confessado, na delegacia, mediante tortura. Foram longos e tensos esses depoimentos. As testemunhas caíram em contradição, várias vezes, especialmente confundindo o réu-Nenê, com o co-réuNenê e com um terceiro Nenê — também do "pedaço" e "da pesada" —, já assassinado. Em outras palavras, a uma certa altura, falava-se em três "Nenês-neguinhos" e ninguém mais compreendia quem era quem.

Depois do primeiro intervalo, para almoço, houve um segundo, para um cafezinho, durante o qual todas as testemunhas, mesmo as que já haviam prestado depoimento, ficaram numa sala contígua à do plenário. Quando da retomada da sessão, um dos dois advogados do réu comunicou ao juiz que, nessa tal sala, havia, sobre a mesa, cópias de várias peças acusatórias do processo, às quais, portanto, as testemunhas tiveram acesso, inclusive as que ainda não haviam deposto. Nesse momento, instaurou-se uma confusão generalizada.

Por decisão do juiz, todas as testemunhas depuseram, novamente, para declarar se haviam ou não lido as peças acusatórias e indicar o nome de quem as deixara sobre a mesa (ninguém apontou "o culpado"). O mesmo ocorreu com todos os funcionários que serviam no Júri, os quais, portanto, passaram a correr o risco de perder o emprego. 
Os jurados, por sua vez, tornaram-se testemunhas dessa possível irregularidade. Advogado de defesa e promotor alteraram-se e acabaram declarando, em altos brados, quais medidas tomariam, um contra o outro.

Finalmente, o juiz, não suportando mais a perda de seu papel soberano, desabafou: "Senhores! São três os que estão agindo aqui como juízes! Eu mesmo e suas excelências! Assim não dá!”’ E, reafirmando sua posição, declarou, com base na lei, dissolvido o Conselho de Sentença, com o que demonstrou domínio técnico-jurídico da situação e domínio político no conflito de soberanias. Eis parte da justificativa que deu aos presentes no plenário para ter interrompido o jogo: "Faltam estrutura física e de pessoal neste Tribunal. Faltam acomodações para que testemunhas de acusação e de defesa permaneçam incomunicáveis. (...). Foi ferido o princípio da ampla defesa (...). Quase dez horas de trabalho foram lançadas ao vento por não ser cumprida a determinação de incomunicabilidade entre testemunhas, a qual não é só verbal, mas de contato com o mundo exterior: telefones, bips, documentos."

Eis, portanto, um exemplo de jogo que não chegou ao fim devido a, pelo menos, dois fatores "lúdico-sociais" que merecem análise: houve uma confusão de posições entre os jogadores (inclusive entre os "Nenês") e acirraram -se tensões entre instituições por eles representadas - Polícia Civil, Militar, Ministério Público, OAB e Judiciário. Foi tão difícil manter o jogo, durante quase dez horas, quanto interrompê-lo, depois desse tempo, o que deixou a todos visivelmente frustrados.

No elevador do Tribunal, um policial militar, que trabalhava na sessão, disse à ascensorista (que já sabia de tudo):

$\Rightarrow$ PM: Dez horas de trabalho perdido, jogado no lixo!

$\Rightarrow$ A: Trabalho e dinheiro!

$\Rightarrow$ PM: Nosso dinheiro!

$\Rightarrow \mathbf{A}:$ Quanta gente aí trabalhou à toa.

$\Rightarrow$ PM: É...Isso é a Justiça...

$\Rightarrow \mathbf{A}: \dot{E} \ldots$

$\Rightarrow$ PM: Parece final de campeonato, quando ninguém marca gol, os jogadores são expulsos e, prá finalizar, o juiz suspende a partida. Não há torcida que agüente! Eu quero meu ingresso de volta! (os dois riram).

Portanto, o Júri, enquanto jogo, possui a característica de ser uma atividade lúdica necessária, não só porque é um ritual reconhecidamente instituído, mas porque reafirma e publiciza status conferidos a jurados - cidadãos idôneos - e a operadores técnicos - cidadãos aplicadores da lei.

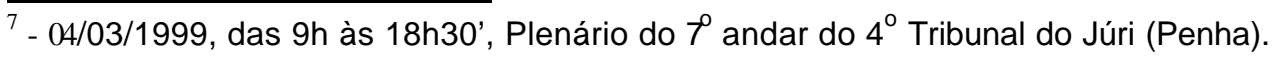


E quanto à dificuldade de uma "partida" ser interrompida, passemos a aprofundá-la analisando outra característica dos jogos também presente no Júri: o fato de toda atividade lúdica representar um "intervalo" na vida cotidiana.

\section{- Tempo e espaço artificiais: "círculo mágico"}

Sessões de Júri, para todos os que delas participam, têm um caráter extraordinário, pois assim como ocorre em jogos e rituais, nelas o tempo e o espaço cotidianos ficam suspensos. Durante seu transcorrer, embora os participantes refiramse a fatos que aconteceram e acontecem em seus cotidianos, eles o fazem em um tempo e um espaço artificialmente criados pelos limites físicos dos plenários, durante os quais experiências difusas e acumuladas "lá fora" são condensadas e reorganizadas no interior das salas de julgamento.

Esses tempos e espaços artificiais são tão marcantes no Júri, que todos os "jogadores" ficam, de algum modo, impedidos de se ausentar das sessões, sob o risco de impugná-las.

Juiz, promotor e defensor, por exemplo, podem transitar entre "os dois mundos", mas de forma restrita e por curtos intervalos de tempo, pois regras tácitas e escritas prendem-nos aos plenários e determinam os momentos em que devem atuar seqüência das sustentações orais, duração das mesmas, possibilidade de apartes etc.

Especialmente a regra da incomunicabilidade, rigidamente aplicada às testemunhas e aos jurados, deixa claro serem os plenários "esferas temporárias de atividade", onde os acontecimentos devem seguir uma orientação própria, que não está em discussão. Essa orientação determina o que "vale" dentro do mundo circunscrito do Júri e desobedecê-la significa pôr fim a ele: “(...) o apito do árbitro quebra o feitiço e a vida 'real' recomeça" (Huizinga, 1980: 14).

Contudo, um jogador que desrespeita regras não é, necessariamente, desonesto, podendo tratar-se apenas de um "desmancha-prazeres" que desilude os demais por inépcia, cansaço, desinteresse ou porque ele próprio está desiludido ${ }^{8}$, ao passo que o desonesto finge jogar seriamente - finge reconhecer o "círculo mágico" mas, na verdade, dele descrê. Geralmente, os desmancha-prazeres contumazes são expulsos da comunidade de jogadores e tendem a associar-se numa nova comunidade, com regras próprias (Huizinga, 1980: 14-15).

8 - Com muita propriedade, Huizinga registra o significado literal do substantivo ilusão: inlusio = illudere $=$ in ludere $=$ em jogo (op. cit: 14). 
Exemplo dessa situação ocorreu no $2^{\circ}$ Tribunal do Júri, durante uma sessão que não terminou devido ao advogado de defesa não conseguir defender o réu ${ }^{9}$. Sua atuação deixou claro, a todos, como um defensor não deve jogar.

Tratava-se de um advogado jovem, realizando seu primeiro Júri. Estava tão nervoso e despreparado que, durante a sustentação oral, mal articulou as palavras. Sem fazer as saudações iniciais de costume e em voz quase inaudível, começou lendo fichas, que ele próprio não entendia. Em momento algum, olhou nos olhos dos demais presentes, muito menos nos dos jurados. Fazendo longas pausas, folheou códigos dos quais nada extraiu, ocasiões em que, sem disfarçar, jurados, juiz e promotor demonstraram impaciência e ar desiludido. As poucas vezes em que alçou a voz, fez colocações que mais pareciam dúvidas do que convicções e, das duas horas de que dispunha para falar, ocupou somente 20 minutos. Ao final desses, o juiz e o promotor estavam visivelmente estupefatos, tanto que o magistrado logo se levantou e pediu aos jurados que se retirassem para a "sala de lanche". Em seguida, chamou o advogado e o promotor para que o acompanhassem até a sua sala. O réu - mulato-escuro, jovem, magro, baixo, que permanecera inquieto durante todo o tempo, balançando as pernas e levando as mãos algemadas ao rosto - virou-se para o policial que o acompanhava e perguntou: "Já acabô, é? Fui condenado?" O policial, meio assustado, meio rindo, respondeu-Ihe: "Não! Ainda não! É só um intervalo." E conduziu o réu para o corredor, onde havia uma cela.

Na "platéia", eu, imediatamente, interpelei um senhor de meia-idade, que assistia à sessão ao meu lado:

$\Rightarrow$ Eu: O senhor é advogado?

$\Rightarrow$ Ele: Sou. Você também? (sorriso cúmplice)

$\Rightarrow$ Eu: Também. O que o senhor acha que vai acontecer?

$\Rightarrow$ Ele: Sem dúvida, o réu tem que ser considerado indefeso! Um advogado que faz Júri tem que aprender vendo outros Júris. Sem contar que só devem atuar no Júri aqueles que têm o dom da palavra, têm postura, são ousados, gostam desse tipo de trabalho. Esse nosso jovem colega, 'data venia', tem muito o que aprender. E digo mais: esses cursinhos preparatórios, que existem por aí, simulam sessões, mas não simulam o principal, que é o ritual hostil do Júri, as muitas pressões que existem lá na frente. Não se aprende "de brincadeira"! Só se aprende jogando prá valer!

Quando o promotor saiu da sala do juiz e passou por nós eu lhe perguntei:

$\Rightarrow$ Eu: O réu será considerado indefeso?

$\Rightarrow$ Promotor: É claro!

$\Rightarrow O$ advogado de meia-idade: $E$ o que 0 juiz declarará aos jurados em relação ao defensor?

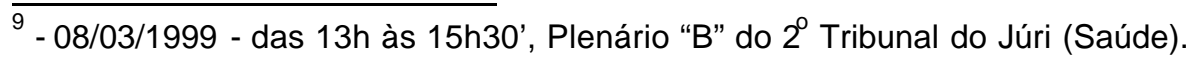


$\Rightarrow$ Promotor: Dirá que ele se sentiu mal e precisou se ausentar. Vamos e venhamos... É o primeiro Júri do moço. Não convém prejudicá-lo!

Um conjunto de regras implícitas e explícitas do Júri foi testado nessa sessão, como a necessidade de narrar, com segurança, no tempo e no espaço, especialmente destinados para isso, duas versões: uma que inocente ou redima o réu do ato criminoso e outra que o condene. A fraca atuação do defensor mostrou que o descumprimento dessa regra inviabiliza o jogo, logo a narração segura de versões contraditórias é um aspecto fundamental do jogo.

É opinião corrente entre "mestres" do Júri, bem como uma das lições que eles mais enfatizam junto aos novatos, que nesse jogo imaginativo e persuasivo de construção de narrativas, quem não jogar bem é um perdedor, e aquilo que perderá será, nada menos, que sua própria honra: "Não é possível errar, (...). O advogado põe em jogo todo o seu cabedal de conhecimentos, todo o seu fervor profissional, a sincera compenetração de seu convencimento pessoal, seu talento e sua glória." (Silva, 1991: 17).

No caso em questão, o réu era ex-amásio da vítima, mãe de quatro filhos, e ela foi espancada, até morrer, na frente de seu barraco - a favela, por sinal, deixou de existir entre a data do crime e a do Júri. Enquanto o promotor foi incisivo e apresentou, com clareza, provas contra o réu, as quais declarou "indiscutíveis", pedindo aos jurados que o condenassem por homicídio duplamente qualificado (motivo torpe e por ter o réu infringido à vítima "sofrimento cruel e desnecessário"), o defensor balbuciou, com frases redundantes, que fora o réu perseguido pela vítima e por isso revidou seus golpes de faca.

$\Rightarrow$ Promotor (apartando o defensor): Mas a vítima, mulher franzina, foi encontrada vestindo apenas uma camiseta regata, senhores jurados!

$\Rightarrow$ Defensor (desconcertado): É, de fato, mas...

$\Rightarrow$ Promotor (com a foto do cadáver da vítima na mão, aproximando-se de uma jurada - a única mulher do Conselho): Hoje, Dia Internacional da Mulher, olhem para este cadáver e me digam: essa mulher poderia representar uma ameaça a este homem? Mesmo que empunhasse uma faca? Bastaria um soco para desarmála! Mas ela foi espancada por ele até morrer!

Aquela fala do réu, após o término da sustentação oral de seu defensor - "Já acabô, é? Fui condenado?" -, aparentemente reveladora de profunda incompreensão do que se passava, demonstrou, na verdade, estar ele percebendo muito bem a grave situação em que seu defensor "desmancha-prazeres" o colocara, pois, de fato, a sessão estava acabada e, se aquela defesa valesse, ele seria condenado. O defensor, por sua vez, apesar da frustração que causou a todos, foi protegido pelos "jogadores mais 
experientes", afinal, ele não era um desonesto e não merecia ser, tão precocemente, expulso da comunidade.

Os jurados, por sua vez, ao saírem da "sala de lanche", estavam com expressões semelhantes às do PM e da ascensorista do Tribunal da Penha, quando daquela outra sessão impugnada - Caso "Nenês". E os poucos assistentes que me rodeavam, incluindo o advogado de meia-idade, não entenderam por que eu fizera tantas anotações e estava tão animada ao partir.

Vários outros casos poderiam exemplificar como a desobediência a certas regras - implícitas ou explícitas - leva à "quebra" do caráter extraordinário do Júri, desmantelando-o, pois cumpri-las é garantia da retirada dos jogadores da "vida real" e seu transporte para a "vida narrada". Se as narrativas forem mal elaboradas, mesmo que os jogadores permaneçam confinados num plenário que os isole do mundo externo, eles não alcançarão o que está para além desse mundo e que, em última instância, é uma das principais razões de ser do Júri. Eles não chegarão ao fundamento de suas próprias ações, espelhadas nas ações atribuídas ao réu, e não construirão, concederão ou negarão legitimidade às ações do réu e às suas próprias; consequentemente, não julgarão e o jogo fracassará.

Eis um exemplo de operador técnico que desistiu do jogo, por justamente desacreditar de sua validade, declarando-se "desiludido" com o Júri, após anos de atuação: "Eu não tinha mais o que fazer lá, pois não conseguia mais acreditar no sentido daquilo. De que adianta condenar aqueles pobres coitados a penas de 10, 20 ou 30 anos de reclusão? Me diga?! De que isso adianta? Além do mais, se considerarmos a maneira incorreta como a imensa maioria das provas é coletada e periciada e como são realizados os inquéritos na polícia, aí então é que não se consegue julgar mais ninguém. (...). Não! Não! Ou eu abandonava a área criminal e especialmente o Júri ou eu acabaria morrendo de gastrite, de câncer no pulmão, de tanto fumar, e de depressão“. ${ }^{10}$

Enfim, retirar as pessoas de seus cotidianos, repletos de experiências, geralmente não sistematizadas, e levá-las para a dimensão de um mundo de narrativas que requalificam e reorganizam esses cotidianos, segundo determinadas regras e valores, implica desconectá-las do conjunto formado por suas necessidades, hábitos e formas triviais de pensar e de agir para conectá-las a esse próprio conjunto, porém em uma outra dimensão. Por isso, jurados ficam incomunicáveis durante as sessões, desconectados de suas famílias, trabalhos e demais afazeres do dia-a-dia, embora seja,

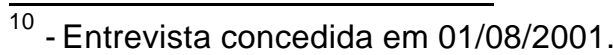


com base em vivências familiares, profissionais e cotidianas que julguem os réus. Pela mesma razão, durante as horas de Júri, operadores técnicos permanecem presos ao ritmo dos procedimentos judiciais e réus aguardam, como estátuas-vivas, o que será dos próximos anos de suas vidas.

Esse isolamento artificial que delimita um lugar de jogo comum a quase todos os rituais de consagração e de iniciação, assemelhando delimitações espaciais para fins sagrados e para fins lúdicos (Huizinga, 1980: 13, 23). Tais delimitações são muito nítidas nos plenários do Júri. Neles há locais proibidos, isolados, fechados e secretos, bem como outros por onde transitam os que não fazem parte do jogo. O mundo das sessões é temporário, regrado e, quem quer que o observe, percebe isso.

O espaço dos tribunais, portanto, confirma a qualidade lúdica do direito e, especialmente, do moderno processo jurídico, pois ele é “(...) um círculo mágico, um recinto de jogo no interior do qual as habituais diferenças de categoria entre os homens são temporariamente abolidas" (Huizinga, 1980: 88). O próprio uso da toga, por juízes, promotores e advogados, ao mesmo tempo assemelhando-os entre si e distingindo-os dos demais, marca sua transformação, pois, ao vestirem-na, registram a passagem de seres "comuns" a seres "especiais".

Em todos os plenários, o espaço onde juiz, jurados, promotor, defensor e réu permanecem, durante o julgamento - o "palco" ou o "círculo sagrado" —, é separado do local profano, reservado aos "assistentes" (estagiários, familiares de réus e vítimas, outros profissionais, curiosos etc). 


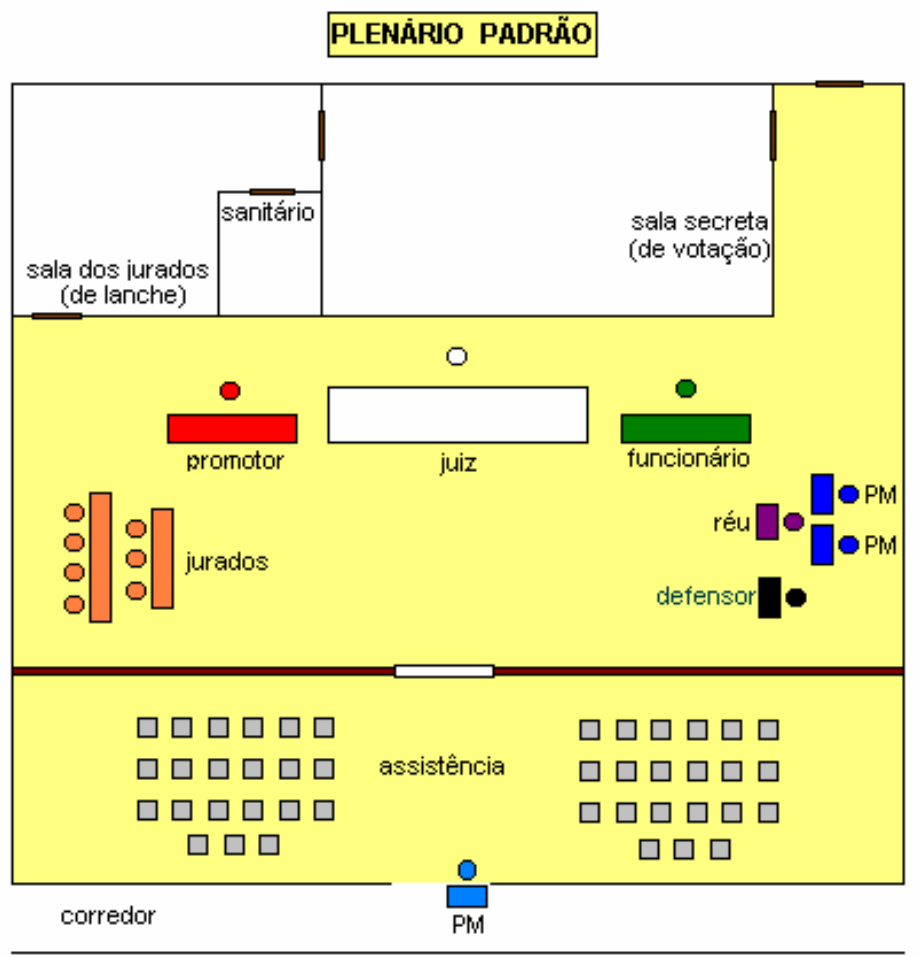

Atualmente, na maioria dos plenários paulistanos, o que separa, fisicamente o "lugar de jogo" do restante do espaço é uma divisória de aproximadamente $60 \mathrm{~cm}$ de altura que se estende, de parede a parede. Mesmo sentados, os assistentes podem ver o que se passa "do lado de lá", mas, como nos antigos altares de igrejas católicas, neles entrar tem gosto de pecado, pois sabe-se que é proibido, apesar de nenhuma placa alertar para isso.

Embora, em alguns plenários, os jurados fiquem à frente e à direita do juiz, com réu, defensor e PMs à esquerda e, em outros, essas posições se invertam - jurados à esquerda; réu, PMs e defensor à direita —, a distribuição dos protagonistas é basicamente sempre a mesma, invariando o fato de juiz e promotor posicionarem-se lado a lado, de frente para a assistência.

"O fato de promotor e juiz ficarem próximos, no espaço do plenário, passa aos jurados a impressão de que o jogo tem, de um lado, promotor e juiz, como autoridades e, de outro, advogado e réu, como comuns mortais; o advogado com um pouco mais de status do que o réu. (...) Os jurados como autoridades temporárias."

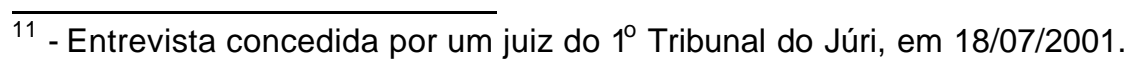


Opinião idêntica expressou um Procurador de Justiça aposentado, ao proferir uma palestra sobre "A Evolução Histórica do Júri" :"(...) a autoridade do juiz e a do promotor se confundem como sendo as verdadeiramente imparciais e corretas, ficando o advogado como suspeito, alguém parcial. Desqualifica-se, assim, seu papel necessário de garantir o direito de defesa.",12

Vale lembrar que as posições de promotor e juiz nem sempre foram essas, conforme se pode observar na "Grande Sala do Júri do Palácio de Justiça"13, hoje "Museu do Júri". Até meados do século passado, promotor e advogado sentavam-se junto ao juiz: um de cada lado, ocupando a mesma mesa ${ }^{14}$.

Em todos os plenários, mesmo nos mais novos, a mesa do juiz situa-se num plano um pouco superior ao do restante da sala. Geralmente, um grande relógio, semelhante aos das estações de metrô da cidade (com marcações bem visíveis de horas e minutos), fica sobre a porta do corredor, do lado de dentro - às costas, portanto, dos assistentes -, e é por ele que o juiz controla o tempo dos depoimentos, sustentações orais, apartes e intervalos.

No espaço vazio do palco, pode ser colocada uma cadeira, com uma pequena mesa, para que testemunhas e réus deponham, o que sempre fazem de frente para o juiz e, portanto, de costas para a audiência.

Os plenários, portanto, seja por sua estrutura física, seja pelas regras processuais penais que conduzem as sessões, constituem um campo onde as posições dos ocupantes estão bem definidas e têm significados que nos cabem ler e interpretar. Existe ali uma "gramática espacial" a ser decifrada.

Os próprios jurados, que representam o elo entre o mundo "de fora" e o "de dentro", entre ser leigo e possuir um saber técnico, ao chegarem, costumam ser

\footnotetext{
12 - Palestra proferida em 10/05/1999, das 9h às 10h30', pelo Dr. Hermínio Alberto Marques Porto, no curso "O futuro do Júri no Brasil". O programa completo desse curso, promovido pelo Centro de Estudos e Aperfeiçoamento Funcional da Escola Superior do Ministério Público de São Paulo - CEAF/ESMP —, com os títulos das demais palestras e nomes de seus respectivos palestrantes, encontra-se no Anexo 1. Agradeço a seu coordenador, Dr. Herberto Magalhães da Silveira Júnior, por ter autorizado minha excepcional inscrição junto a 59 promotores e 60 estagiários do MP que participaram do evento.

13 - Situada no centro da cidade de São Paulo, à Praça Dr. João Mendes.

14 - Numa pesquisa, já mencionada (Nucci, 1999: 160, 346-347), uma amostra de jurados do $3^{\circ}$ Tribunal do Júri de São Paulo respondeu às seguintes perguntas: "Acha correto o promotor sentar-se ao lado do juiz no plenário?" - 26,55\% responderam que sim; $20,58 \%$ que não e $52,88 \%$ declararam-se indiferentes - "O promotor deveria sentar-se ao lado do defensor no plenário?" - 15,71\% responderam que sim; $28,98 \%$ que não e 53,32\% declararam-se indiferentes. Essas respostas, segundo Nucci, não revelam se os jurados confiam mais no promotor do que no defensor, devido à disposição dos mesmos, em plenário, mas ele acredita que "O cidadão leigo, menos avisado ou prudente" deixa-se influenciar.
} 
orientados, por cartazes e/ou por funcionários, a sentar-se do lado esquerdo da assistência, devendo os demais - "Srs. estagiários, familiares de réus e vítimas e assistentes de um modo geral" - ocupar os lugares da direita. Outro cartaz lembra: "Durante as sessões de julgamento, deverá ser mantido absoluto silêncio!!! Aparelhos celulares, bips e afins deverão ser mantidos desligados!!!"

No interior dos plenários, portanto, os espaços destinados à atuação de cada participante não só estão delimitados como delimitam a sala enquanto um lugar especial; um lugar de jogo. Mesmo vazios, esses lugares parecem manter uma aura não profana, como ocorre com templos desocupados.

A sala dos jurados - para onde retiram-se nos intervalos das sessões, de modo a permanecerem sem contato com o "mundo externo" - e a sala secreta — local onde proferem seus sigilosos votos definidores do desfecho dos julgamentos - , talvez sejam os exemplos máximos dessa circunscrição que especializa, sacraliza e separa o mundo do ritual do mundo cotidiano. Essas salas são espaços circunscritos para e pela cerimônia, o que confirma que "A noção de jogo associa-se naturalmente à de sagrado." (Huizinga, 1980: 30).

\section{SALA SECRETA PADRÄO}

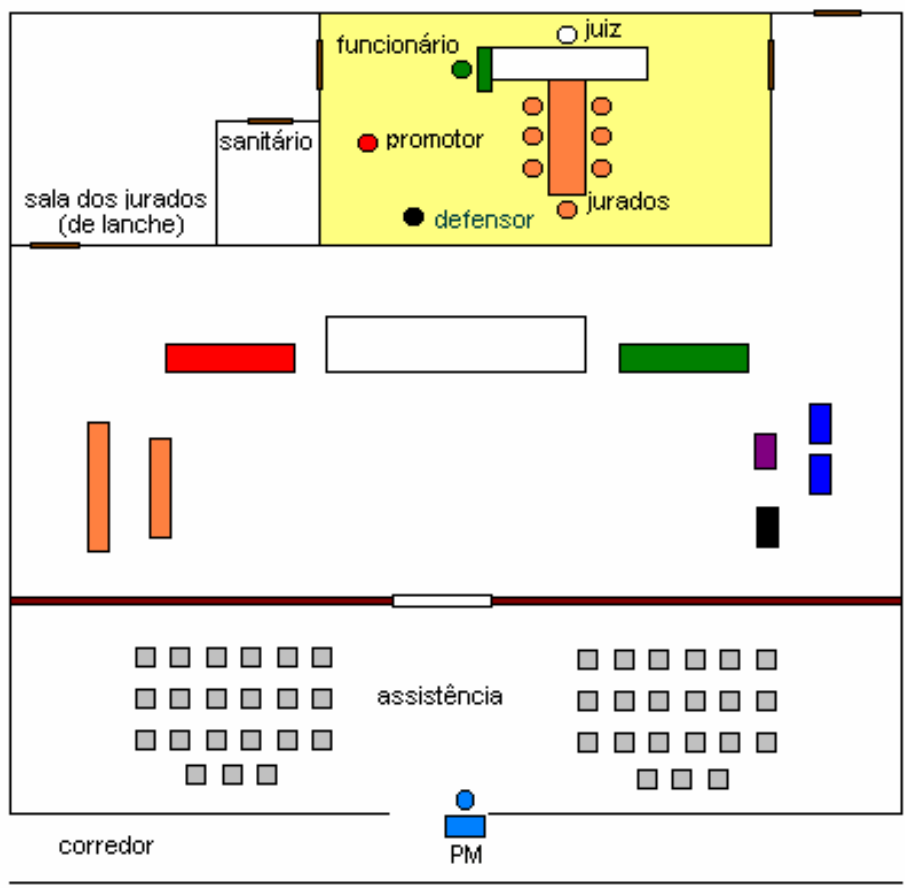

Se observarmos, atentamente, os dois croquis que representam os plenários padrão, perceberemos que o espaço total é dividido em outros três: O "dos fundos", 
reservado somente para jurados, operadores técnicos e funcionários do tribunal vetado a outras pessoas -; o "do meio" que, durante as sessões, abriga, além desses, também réus e PMs - também vetado a outras pessoas; e o "da frente", aberto a todos e ocupado por assistentes que podem entrar e sair, a qualquer momento. A única entrada é sempre guardada por um PM.

Uma decodificação possível dessa gramática espacial é a identificação de dois eixos imaginários: um horizontal $(区)$ ligando o espaço ocupado pelos jurados ao ocupado pelo réu e seu defensor, e outro vertical $(\varangle)$, perpendicular ao anterior, ligando juiz ao centro da assistência.

Em torno do primeiro eixo $(\bigotimes)$, constroem-se os sentidos das narrativas que têm como objetivo persuadir os jurados - é o eixo pelo qual fluem as palavras, a gestualidade e todos os demais sinais dessa linguagem persuasiva. No outro eixo $(<)$, em posições homólogas e opostas, estão o juiz e a assistência, o representante máximo da lei e uma mínima representação da sociedade. Uns e outros formam uma espécie de corredor pelo qual flui a linguagem persuasiva. As imagens dessa linguagem têm de escoar pelas margens, limites e referências desse "corredor", impregnando-se das regras e procedimentos legais, de um lado e, de outro, de normas e valores sociais. Esses elementos são a matéria prima das narrativas. O orador que melhor elaborá-la, no sentido de melhor sintonizar-se com os enigmáticos e silenciosos jurados para, de fato, convencê-los e atingi-los, com seus argumentos, será o vencedor do jogo.

Outra leitura possível, menos profana, é a de que sacralizase, no "círculo mágico" desse ritual lúdico do Júri, especialmente no espaço aparentemente vazio e central do plenário, algo que está no limiar entre o divino e o humano: o exercício e o poder de julgar vidas e mortes, tanto que o réu, no momento de ouvir a sentença, ocupará esse espaço central, postando-se em pé, de frente para o juiz.

Tanto uma leitura quanto outra sugerem semelhanças entre a gramática espacial dos plenários e a de uma tradicional igreja católica apostólica romana. Nessa também temos as três divisões: o fundo do altar, ocupado pelo sacrário - secreto, fechado, só acessível ao padre - , o meio do altar, com a mesa do sacerdote ao centro e cadeiras laterais para demais participantes seletos da missa - coroinhas, fiéis que lerão passagens da Bíblia, outros sacerdotes etc - e, separados por uma divisória de degraus e/ou de uma grade baixa, à frente do altar, ficam os bancos para os fiéis. $A$ maior diferença entre o que se passa nos espaços do plenário e da igreja católica, talvez, seja que, nela, o eixo imaginário pelo qual flui a linguagem persuasiva é, 
principalmente, o vertical $(\mathfrak{I})$, que liga sacerdote a fiéis. Inclusive, antigamente, no momento do sermão, da "conversa" mais direta e informal entre sacerdote e fiéis, ele saía do altar e ocupava o púlpito, situado num ponto alto, dentro do espaço reservado aos fiéis.

Mas, tanto nas igrejas como nos plenários, temos atos de culto a valores morais. No caso da igreja, esses são metaforizados por Deus, seus santos e interpretações de textos bíblicos, no caso dos plenários, a lei e interpretações de peças processuais permitem a metáfora.

\section{- Arrebatamento, tensão, competição, futilidade e êxtase}

Relacionada a esse caráter extraordinário do tempo e do espaço dos jogos e dos cultos, há algumas outras características que também podem ser observadas nas sessões de Júri e que o famoso advogado Evandro Lins e Silva assim condensou: "Ninguém ouviu grande defesa sem a vibração, o calor, o entusiasmo, o arrebatamento do advogado. Defesa sem vigor, sem dedicação, sem sentimento, é defesa sem vida, fria, fadada ao insucesso, defesa de perdedor de causas. Os processos do júri fazem tremer o advogado." (Silva, 1991: 18)

Esse é apenas um exemplo das muitas "orientações" que advogados e promotores famosos do Júri brasileiro transmitem em livros, aulas e palestras aos futuros "tribunos". É opinião corrente entre eles que, além do domínio técnico das "regras do jogo", há que se ter o domínio estratégico de como usálas bem. Tal domínio implica conhecimentos de oratória, o uso de uma gestualidade estudada, enfim, daquilo que o criminalista Thales Nilo Trein chama de linguagens do plenário (Trein, 1996), as quais, em diferentes momentos deste capítulo e desta tese, tentamos "decodificar".

Em palestra ministrada num curso sobre $O$ futuro do Júri no Brasil, esse criminalista enfatizou o quanto a comunicação em plenário vai além das palavras, chegando a mensurar que a linguagem verbal utilizada por advogados e promotores representa não mais do que $7 \%$ do impacto que causam nos jurados. Já a sonoridade de suas vozes - ênfases e inflexão, além do ritmo das falas - são mais impactantes $(38 \%)$, perdendo somente para suas performances corporais - gestos e fisionomias $(55 \%) .^{15}$

\footnotetext{
$\overline{15}$ - 21 de junho de 1999, das $9 \mathrm{~h}$ às $12 \mathrm{~h}$; palestra intitulada Neurolinguística em Plenário. (Anexo $1)$.
} 
Desse mesmo ciclo de palestras, participou um famoso promotor que, ao se referir ao "clima" do Júri, mencionou o quanto ele exige "gana", ou seja, "um estado de espírito de quem está arrebatado pela causa". ${ }^{16}$

O ponto em questão é que a consciência de, no jogo, haver um "faz-de-conta", ou de se estar vivendo um tempo e um espaço artificiais, não impede que ali se aja com seriedade, enlevo e entusiasmo, a ponto de fazer com que os jogadores sintam-se arrebatados pelo jogo e distantes de suas vidas e preocupações cotidianas.

"A alegria que está indissoluvelmente ligada ao jogo pode transformar-se, não só em tensão, mas também em arrebatamento. A frivolidade e o êxtase são os dois pólos que limitam o âmbito do jogo." (Huizinga, 1980: 24)

Tratemos dessas emoções, inicialmente, em relação aos réus. É, normalmente, de mãos entrelaçadas e repousadas sobre as pernas, de cabeça baixa e absortos naquilo que "só eles sabem", que a maioria dos réus permanece ao longo das sessões de julgamento pelo Júri. Quando muito, há momentos em que deixam certa tensão transbordar pelo olhar, por expressões faciais e por um balanço compulsivo de pés e pernas. Mas a maior parte deles permanece como permaneceu o "Sr. S" durante uma entrevista que me concedeu. Ele assistia ao julgamento e fora co-autor, já julgado e inocentado, do crime pelo qual sua companheira também estava sendo julgada. Imagino que, durante seu próprio julgamento, tenha permanecido tal como se portou durante o julgamento da companheira: ar resignado diante do longo ritual e para com o desempenho de seus participantes, como se o fato de estar ali fosse, em si mesmo, o cumprimento de uma pena, independentemente do resultado.

Já a tensão que promotor e defensor vivenciam, durante as sessões, é de outra natureza. Está intrinsecamente relacionada aos desempenhos que cada um conseguirá ter. Esse tipo de tensão, como diria Huizinga, significa incerteza, acaso. (...), o jogador quer (...) conseguir alguma coisa difícil, ganhar (...) e quanto mais estiver presente o elemento competitivo mais apaixonante se torna o jogo.(...) o elemento de tensão the confere um certo valor ético, na medida em que são postas à prova as qualidades do jogador: sua força $e$ tenacidade, sua habilidade e coragem (...). Apesar de seu ardente desejo de ganhar, deve sempre obedecer às regras do jogo" (Huizinga, 1980: 14).

Não se pode afirmar que promotor e defensor abstraiam por completo a pessoa do réu, a ponto de esquecerem que se trata de um ser humano que está ali, presente, sentado, aguardando uma sentença que decidirá os próximos anos de sua vida e,

16 - Palestra ministrada pelo Dr. Octávio Borba de Vasconcelos Filho, em 31 de maio de 1999, das $9 \mathrm{~h}$ às $12 \mathrm{~h}$ e intitulada $A$ postura do Promotor de Justiça em plenário. 
provavelmente, todo o restante dela. Mas, enquanto jogadores, é quase isso que acontece: "O réu e sua versão praticamente se tornam secundários em cena. É como a bola no futebol. Ela é essencial para que o jogo aconteça, mas o que de fato importa são os dois times e o que eles fazem. Há faltas fora das jogadas, sem bola. E o juiz é esquecido, em muitos lances..." 17

Embora, desde a Grécia antiga, o litígio judiciário tenha um caráter "agonístico", pois era uma competição de caráter divino submetida a regras fixas, dentre as quais uma das principais determinava que os adversários invocassem a decisão de um árbitro (Huizinga, 1980: cap. 4), as atenções, de fato, costumavam se concentrar nos "contendores", ficando o árbitro como uma espécie de guardião das regras do jogo.

Os dois "times" do Júri , acusação e defesa, representados, respectivamente, pelo promotor e pelo advogado do réu, como já vimos, normalmente jogam em lados aparentemente opostos, mas também podem jogar do mesmo lado, defendendo uma tese comum e, ainda assim, mantendo o jogo interessante e tenso. Da mesma forma, nada garante que, estando em "lados" opostos, promotor e advogado do réu façam uma bela "partida". É a tensão, enfim, que determina o quanto o jogo pode ou não arrebatar seus participantes e assistentes e essa dependerá do quanto os argumentos de um e de outro jogador alcançarem a sensibilidade dos jurados.

Como ao votar, os jurados não podem se abster e suas alternativas são apenas SIM ou NÃO, forçosamente, na sala secreta, a tensão encontra seu apogeu e seu fim.

Certa vez, um antigo juiz comentou com Huizinga: "O estilo e o conteúdo das intervenções nos tribunais revelam o ardor esportivo com que nossos advogados se atacam, uns aos outros, por meio de argumentos e contra-argumentos (alguns dos quais são razoavelmente sofisticados). Sua mentalidade, por mais de uma vez, me fez pensar naqueles oradores dos processos adat - direito aplicável aos indígenas nas Índias Holandesas - que, a cada argumento, espetam na terra uma vara, sendo considerado vencedor aquele que no final puder apresentar o maior número de varas." (Huizinga, 1980: 89)

No jogo do Júri, as varas adat são os argumentos que, ao longo de suas sustentações orais, promotor e defensor reiteram, insistentemente, tentando acertar a sensibilidade dos jurados. Ao arremessarem-nas, seus olhares, gestos, expressões faciais, corporais e vocais acompanham-nas. Fotos escabrosas dos corpos da(s) vítima(s) e laudos complicados, depoimentos testemunhais e provas materiais também ajudam na precisão do arremesso. Tudo é "espetado na terra", nos corações e mentes

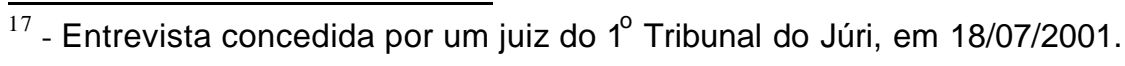


dos jurados e, ao final, esses revelam, através de seus votos aos quesitos, quantas "varas" ficaram "bem espetadas". Assim, chega-se á sentença e é indicado o vencedor.

O desejo de ganhar, típico de qualquer jogo, portanto, está muito presente no Direito e inserido numa dinâmica em que, mais do que pólos definidos e fixos, há atores relacionando-se de modo complexo, em função de um processo que, ao mesmo tempo, eles próprios constróem, mas ao qual também submetem-se.

$\mathrm{Na}$ comparação ampla que Huizinga faz entre o que chama de "nosso pensamento" e de "pensamento primitivo", ou na comparação, mais específica, entre um processo judicial moderno e julgamentos realizados por "sociedades primitivas", reconhece a existência de três formas lúdicas comuns: o jogo de azar, a competição e a batalha verbal. Mas ao desenvolver essa comparação, ele afima que sociedades, culturas ou espíritos "primitivos" experimentam, mais do que "nós", o problema concreto de ganhar ou perder, sem que predominem abstrações como a disputa entre bem e mal. As "culturas primitivas" fundiriam, num só complexo pensamento, as idéias de decisão por oráculos, por juízo divino, por sorte, por sortilégio e por sentença judicial, de tal modo que, em tais culturas, ganhar levaria à posse da verdade e do direito e não o contrário, ou seja, não são a verdade e o direito que levam a ganhar (Huizinga, 1980: 93).

"Só numa fase mais avançada da experiência religiosa, a fórmula será a seguinte: a competição (ou ordálio) é uma revelação da verdade e da justiça porque há uma divindade que dirige a queda dos dados ou o resultado da batalha. (...) A luta pela vitória é sagrada em si mesma, mas, uma vez animada por concepções nítidas acerca do bem e do mal, a luta passa a pertencer à esfera do direito; (...). Todavia, o fenômeno fundamental em todos estes casos é o jogo" (op. cit: 94).

Se considerarmos que o livro em questão foi publicado em 1938, tornam-se mais compreensíveis as constantes oposições entre "pensamento primitivo" e o "nosso pensamento", as quais Huizinga elabora sem praticamente relativizar os dois "tipos". Tal relativização, especialmente para se pensar o Brasil atual, é de fundamental importância, conforme já apontaram antropólogos como Roberto Da Matta e Roberto Kant de Lima, segundo os quais, ambigüidade e sincretismo são claramente perceptíveis nas relações entre as chamadas "ordem pública" e "tradição jurídica" brasileiras, uma vez que elas tanto são modernas - baseadas na igualdade e no individualismo - quanto tradicionais - baseadas em privilégios e "jeitinhos" (DaMatta, 1983, Kant de Lima, 1991 e 1993). 
Enfim, essa digressão, com base nas idéias de Huizinga sobre as relações entre Direito, processos judiciais e jogo, chegando-se a antropólogos que pensam tais relações no Brasil atual, podem auxiliar-nos numa análise sobre o Júri enquanto esfera de luta na qual, nos julgamentos, enquanto batalhas verbais, tanto predominam "primitivas" formas invectivas, insultuosas e veementes, quanto "civilizados" argumentos jurídicos, meticulosos e deliberados. Foram vários as sessões em que presenciei promotor e advogado trocando "farpas", de natureza pessoal, ao mesmo tempo em que mediam seus conhecimentos técnicos.

O próprio Huizinga cita um caso de julgamento, ocorrido na Abissínia, que, se não estivesse remetido à fonte, poderíamos atribuir a um julgamento atual, realizado nos tribunais paulistanos do Júri: "Numa oratória cuidadosamente estudada e extremamente hábil, o acusador desenvolve sua argumentação. O humor, a sátira, alusões sutis, provérbios apropriados à circunstância, o escárnio e o frio desprezo, acompanhados de vez em quando pela mais viva gesticulação e por tremendos berros, tudo isso tende a reforçar a acusação e a confundir o acusado" (Huizinga, 1980: 100).

Abordar o Júri como um ritual lúdico, portanto, é perceber não só os manipuladores técnicos, especialmente promotor e advogado, como contendores numa batalha verbal, mas observar em função de que estratégias essa batalha é desenvolvida: quem mais participa, como o faz e por que o faz (temas dos próximos capítulos).

O que, por enquanto, queremos registrar é que o caráter sacralizado e sério do Direito não exclui suas qualidades lúdicas, assim como o caráter competitivo e lúdico de práticas processuais não exclui posturas sérias e arrebatamento dos praticantes. Nos dois casos - faces de uma mesma moeda - o jogo submete-se a um sistema de regras restritivas que colocam seus participantes no interior de um domínio ordenado e antitético.

\section{- Acordos de "bastidores"}

Mesmo quando, nos "bastidores" do Júri, antes do início de uma sessão, promotor e defensor, na presença do juiz, fazem um acordo para condenar ou absolver o réu - tema dos mais controversos - isso não significa que essa sessão se tornará um "faz de conta" desinteressante, pois as sustentações orais, de qualquer modo, deverão persuadir os jurados a votar e, para tanto, elas deverão ser bem desenvolvidas ao longo de todo o julgamento. 
Segundo alguns juristas, esses acordos ofendem a soberania dos veredictos proferidos pelo Júri, inclusive porque o processo penal brasileiro, salvo exceções relativas a infrações consideradas de pequeno potencial ofensivo, não prevê a possibilidade de transação entre Estado-acusador e réu, ou seja, não prevê acordos entre o representante do Ministério Público e o defensor do réu. Contudo, são relativamente comuns situações em que o juiz presidente do Júri presencia tais acordos.

Promotor e defensor, por exemplo, podem concordar com a culpa do réu, pedindo aos jurados que o condenem pela prática de homicídio privilegiado, caso em que a pena diminuirá de 1/6 a 1/3 (art. 121, $\S 1^{\circ}$ do Código Penal). Nessa hipótese, o promotor abre mão de sustentar eventuais qualificadoras do homicídio e o defensor não pede a absolvição por negativa de autoria ou pela ocorrência de excludentes de ilicitude ou de culpabilidade, como a alegação de legítima defesa, por exemplo. Também há situações em que o acordo é pela absolvição do réu, caso em que somente o promotor abre mão de sustentar a acusação e concorda com o defensor (Nucci, 1999: 124-129).

De um ponto de vista éico-jurídico, há quem aponte como sendo o maior problema de tais acordos o fato de o Ministério Público e a defesa, ao apresentarem uma tese comum, deixarem de informar os aspectos contraditórios da causa aos jurados, como versões divergentes a respeito das intenções do acusado ou de seu envolvimento com a vítima, o que pode induzi-los a acatar a única tese apresentada (Nucci, 1999: 125) ${ }^{18}$. Outros profissionais do Júri não se opõem à ocorrência de acordos, desde que denotem um encontro de opiniões a ser devidamente exposto aos jurados para que o avaliem ${ }^{19}$.

É unânime, todavia, que acordos não devem ocorrer quando se prestam apenas a tornar as sessões mais fáceis, rápidas, mecânicas e consequentemente, "não arrebatadoras" para promotores, advogados e juízes que, em poucas horas poderão se desincumbir de suas tarefas. Quando isso acontece e os jurados percebem "o jogo de cartas marcadas", duas são as decorrências mais comuns: ou eles contribuem para que

\footnotetext{
18 - Quase a totalidade de uma amostra de jurados do $3^{\circ}$ Tribunal do Júri de São Paulo (87,83\%) declarou saber ter autonomia para decidir casos em que promotor e defensor sustentam a mesma tese. Todavia, ao responderem se, nessas situações, sentiam -se compelidos a acatar tal tese, $39,16 \%$ declararam que sim; $15,49 \%$ que às vezes e somente $38,27 \%$ que não. Lembra ainda o juiz que desenvolveu essa pesquisa de opinião, que de um total de 1.524 julgamentos realizados, nos últimos 18 anos, naquele tribunal, houve somente um caso em que Ministério Público e defesa pediram a absolvição do réu e o Conselho de Sentença o condenou (Nucci, 1999: 128, 353 e 354).

19 - Essa é a opinião que o Promotor Dr. Octávio Borba de Vasconcelos expressou ao final da já mencionada palestra ministrada no curso sobre $O$ futuro do Júri no Brasil, em 31 de maio de 1999.
} 
o julgamento termine o mais cedo possível, para todos irem logo embora, ou formulam perguntas que demandam maiores explicações e até votam contrariamente à tese comum apresentada ${ }^{20}$.

De um ponto de vista lúdico, pensando a sessão enquanto um jogo, cabe, antes de mais nada, questionar para quem ela normalmente é - ou pode ser — absorvente e arrebatadora. Para promotor e defensor? Para esses e também para os jurados? Para todos os presentes, inclusive juiz, réu e assistência? Comecemos a responder pela negativa.

Os julgamentos costumam não arrebatar ninguém quando promotor e advogado estão desinteressados pelo seu transcorrer, o que pode se dar independentemente de ter ou não havido "acordos de bastidores". Presenciei tanto julgamentos em que promotor e defensor defenderam, com ardor, uma tese comum, tornando o jogo absorvente, quanto julgamentos em que as teses eram conflitantes, porém apresentadas sem "brilho" ou, como diria Thales Nilo Trein, sem o domínio da linguagem devida: discursos excessivamente técnicos, redundantes e longos; voz monocórdia ou inaudível; mau uso de expressões corporais e de recursos performáticos. Portanto, são os dois — promotor público e advogado de defesa — os maiores responsáveis pelo potencial arrebatador do jogo do Júri. Eles são os principais jogadores.

Acompanhei especialmente dois julgamentos em que promotor e defensor atuaram como parceiros, defendendo, com empenho, teses semelhantes, de modo que as sessões não se tornaram enfadonhas. $O$ eixo desses julgamentos deixou de ser 0 embate entre versões conflitantes e passou a girar em torno da habilidade dos jogadores harmonizarem seus argumentos.

\footnotetext{
$\overline{20}$ - Considerando a totalidade das sessões a que assisti, do começo ao fim, ao longo dos 4 anos em que freqüentei os Tribunais do Júri de São Paulo, presenciei não mais do que $20 \%$ de situações de "jogo rápido". Talvez elas sejam bem mais freqüentes, mas não posso tirar conclusões a respeito, uma vez que não adotei um critério estritamente aleatório para selecionar as sessões a que assistia. Muitas das que acompanhei, escolhi por conhecer, de nome ou pessoalmente, juízes, promotores e advogados, e mesmo por supor que, estando os plenários com muitos assistentes, os julgamentos poderiam ter especial interesse. Os dois casos mais evidentes de "jogo rápido" que presenciei ocorreram em 1999: um se deu em 22 de fevereiro, no $1^{\circ}$ Tribunal (quando ainda localizava-se em Vila Mariana) - advogado e promotor defenderam a condenação do réu por homicídio privilegiado; ele recebeu pena de 2 anos, com direito a sursis - e outro, em 05 de março, no $3^{\circ}$ Tribunal (Saúde) — o réu foi absolvido por falta de provas, de acordo com o próprio promotor. No primeiro caso, a sessão durou uma hora e 15 minutos e, no segundo, uma hora e trinta. Em ambos, os jurados, visivelmente amuados, não criaram qualquer obstáculo para o rápido desfecho.
} 
Coincidentemente, nos dois casos, os réus estavam envolvidos com segurança. Num processo, o réu, à época do crime, fazia segurança privada numa padaria e, em outro, o réu era Policial Militar. No primeiro, não presenciei o acordo, pois, como desconhecia o juiz, o promotor e o advogado, não tive acesso aos "bastidores". No segundo, presenciei-o. Em ambos, as sustentações orais do promotor e da defesa mantiveram uma certa tensão, embora convergissem para uma tese comum.

No "caso Segurança" ${ }^{21}$, o promotor, durante uma sustentação relativamente longa (das 13h55' às 15h), bem articulada, baseada em argumentos claros e acompanhados de uma gestualidade congruente com seu discurso, enfatizou que a vítima, segundo a perícia, estava embriagada, mas que nenhuma testemunha confirmara ter sido o réu agredido por ela. Elevando seu tom de voz, gesticulando bastante e aproximando-se ao máximo dos jurados, assim concluiu sua argumentação: "O réu tinha outras alternativas. O que não tinha era preparo para usar uma arma de fogo e ser segurança. Aliás, nunca fez um curso, um treinamento. Todos os dias, nesta cidade, sabemos de pessoas que, usando indevidamente uma arma, saem por aí, matando (...). A vítima também contribuiu para o que aconteceu, pois estava embriagada, xingou. Mas pagou com a própria vida! E o réu, que não sofreu sequer um arranhão? Como pagou por ter tirado a vida da vítima? (...). Enfim, o réu não merece ser absolvido. Deve ser condenado por homicídio privilegiado e cumprir uma pena de 4 anos. Esse valor de pena, conforme prevê a lei, dá ao réu o benefício do sursis, ou seja, de cumpri-la em liberdade, não podendo portar armas. Mas poderá ter uma vida normal e é justo que a tenha, pois é primário e possui família. (...). Peço, portanto, que os senhores condenem esse homem por homicídio privilegiado, pois, se assim decidirem, estarão impedindo que o réu torne a matar." (enquanto pronunciava essas palavras finais, punha e tirava a arma de cima da mesinha, em frente aos jurados, fazendo barulho). "Peço a Deus que ilumine a mente de todos vocês para que saiamos daqui, nesta tarde, fazendo justiça!"

O defensor, inicialmente, inseguro - sem olhar para os jurados e mais fazendo um relato de sua carreira no Júri do que entrando no mérito da defesa -, impôs-se, aos poucos, e também desenvolveu uma sustentação oral articulada e relativamente longa (das 15h10' às 16h05'). Visivelmente, "ganhou" a atenção dos jurados quando, na metade final de seu discurso, disse: "Triste é o país que propicia a necessidade de se ter

\footnotetext{
$\overline{21}$ - 18/03/1999, das 13h40' às 16h30', Plenário II do $3^{\circ}$ Tribunal do Júri (Santo Amaro): o réu negro de 25 anos, grande e forte - foi preso em flagrante, portanto um arma de fogo, e confessou ter matado a vítima - de compleição física semelhante à sua. O réu "fazia segurança" na padaria em que a vítima apareceu para beber. Um amigo do réu também estava presente e, dias antes, recebera um carro como pagamento de uma dívida. A vítima conhecia o devedor e, ao sair embriagada da padaria, socou o tal carro, momento em que foi interceptada
} 
seguranças como o réu, seja porque não há segurança pública suficiente e eficiente, seja porque há desemprego em massa. (...). Quem é esse réu? É alguém que não teve a oportunidade de estudar como muitos dos que estão aqui (...). São pessoas como os senhores [apontou para os jurados e para a platéia] que precisam e requisitam seguranças como o réu. (...). Que país desgraçado é este, pois este homem deveria integrar os quadros da Polícia Militar ou da Polícia Civil. (...). Não tenham raiva de seguranças... É uma profissão que, embora contribua para $o$ aumento da criminalidade, atende aos anseios da própria sociedade que se sente desprotegida. Isto se chama miséria, desemprego, necessidade. (...) Os jurados que têm discernimento devem ter percebido que o réu não é um bandido, por isso a tese da defesa coincide com a do MP".

Após lembrar que a vítima “(...) não era nenhum santo" e de fazer uma breve dissertação sobre os efeitos depressivos ou excitantes da embriaguez, enfatizando que "todos somos agressivos, mas, normalmente, temos freios", reconheceu que o réu não agiu em legítima defesa, pois excedeu-se nos disparos. Finalmente, encerrou sua sustentação com argumentos contrários à impunidade: "Nós pagamos as contas dos que estão presos!! Uma pesquisa recente constatou que cada preso custa para o Estado mais ou menos 200 ou 300 dólares por mês. Se o réu ficar em regime aberto, nós não pagaremos suas contas!! E não pensem os jurados que o réu ficará impune, como se estivesse em férias. Uma condenação de 4 anos, neste país, não se confunde com impunidade, pois, se houver descumprimento das prescrições estabelecidas, o réu regredirá para o regime fechado. No 3 Tribunal do Júri de Santo Amaro, ninguém põe azeitona na empada do outro. Se o MP e a defesa, portanto, têm uma tese comum é porque é a mais justa. E há um jurado antigo aqui que sabe bem disso!"

Promotor e defensor, portanto, concordaram com o despreparo do réu para ser segurança e com o conseqüente excesso de sua reação perante a vítima. Também convergiram ao apontar "defeitos" na vítima que teriam contribuído para causar sua própria morte. O defensor, ainda, ao identificar os jurados classe-média com empregadores de seguranças como o réu, fê-los, ao mesmo tempo, cúmplices dessa situação e avessos a ela, pois colocou-os ao lado do réu, mas pediu que o condenassem. Por fim, promotor e defensor fizeram convergir novamente seus discursos ao afirmarem que o sursis não significava impunidade.

No jogo que se desenvolveu durante essa sessão, defesa e acusação saíramse vencedoras, pois conseguiram arrebatar os jurados ao construírem narrativas convincentes. Os fundamentos por eles utilizados criaram condições para que tais

pelo réu. Atracaram-se e o réu deu-lhe 4 tiros (3 no peito e um no abdômen), matando-a. Segundo o réu, ou fazia isso, ou poderia morrer. 
narrativas fizessem eco junto aos valores dos jurados ou, em outras palavras, para que fossem por eles percebidas como verossímeis.

\section{???}

No "Caso Ex-PM" ${ }^{22}$, promotor e defensor acordaram, na sala secreta, diante do juiz e de mim, minutos antes de iniciar-se a sessão, que retirariam tanto uma das qualificadoras do homicídio de que o réu era acusado como autor, quanto do homicídio em que ele era acusado como partícipe. "Retirada de qual delas?", perguntou o juiz. "Eu decido e o colega advogado me acompanha", respondeu o promotor. O advogado assentiu, com a cabeça, e o juiz comentou, com ar meio zombeteiro: "Prestem bastante atenção, então, no que um e outro vai dizer, hein!". Em seguida, num tom bastante informal, os três comentaram que a nova pena, portanto, seria de 14 anos, o que, na prática, significaria aproximadamente 2 anos e meio em regime fechado. Já a caminho do plenário, o promotor comentou comigo: "Na prática, mesmo, isso significa liberdade para o réu, porque se fosse eu, desapareceria. O homem que está sendo julgado hoje não é mais o mesmo de dezesseis anos atrás. É só ele comprar uma passagem da Itapemirim e sumir."

O acordo somado a esses comentários poderiam levar qualquer um que os presenciassem à conclusão de que aquela sessão seria um jogo desinteressante de cartas marcadas, contudo, não foi o que ocorreu.

A sustentação oral do promotor foi longa (das 13h36' às 15h20'), pois ele leu várias peças processuais e comentou-as, detalhadamente. Contou múltiplas microhistórias que entrecruzou, de forma nem sempre clara, tanto que os jurados, em certos momentos, expressaram incompreensão. Até as 15h05', havia somente reiterado o pedido de condenação. Apenas então, pediu aos jurados que negassem o motivo torpe — vingança - pois nada provava que as vítimas tinham assaltado o réu e de que esse, depois, as teria procurado para vingar-se. Um jurado, não satisfeito, perguntou se existia boletim de ocorrência - B.O - desse suposto assalto. Foi o defensor quem indicou as páginas em que o B.O encontrava-se no processo e o promotor as leu,

\footnotetext{
${ }^{22}-15 / 08 / 2001$, das $12 \mathrm{~h}$ às $16 \mathrm{~h} 45$, Plenário 7 do $1^{\circ}$ Tribunal do Júri (Barra Funda): tratava-se do $3^{0}$ julgamento do réu por autoria de um homicídio duplamente qualificado (motivo torpe + recurso que impossibilitou a defesa da vítima, incisos I e IV do art. 121 do CP) e por participação em outro homicídio, igualmente qualificado duas vezes. No $1^{\circ}$ julgamento, foi condenado a 35 anos, mas houve anulação por falha técnica no libelo acusatório. No $2^{0}$, foi novamente condenado, a 31 anos, e houve protesto por novo Júri (recurso sempre possível quando a pena excede 20 anos). Esteve detido por apenas 8 dias, em prisão disciplinar. O crime ocorreu em 23/08/1985. Consta que o réu, juntamente com seu enteado, matou dois homens que eram irmãos, no interior de um barraco, porque, tempos antes, eles o roubaram.
} 
enfatizando as vagas descrições dos assaltantes. Encerrou concluindo que "(...) o passar do tempo é quem mais tem ajudado o acusado."

A sustentação oral da defesa foi um pouco mais curta (das 15h50' às 16h12') e, logo de início, o advogado afirmou ter opinião semelhante à do MP, exceto num ponto. Defendeu a tese de que a vingança só é qualificadora de torpeza quando representa uma maldade exacerbada e uma absoluta falta de escrúpulos. Cita como "exemplo clássico", o pai que mata o estuprador da filha, caso em que sua vingança tem relevante valor moral, até justificando a diminuição de sua pena.

Confrontou sua argüição com a do promotor e concluiu que, por motivos diferentes, ambos pediam a condenação do réu sem a qualificadora da torpeza. Escreveu num quadro, próximo aos jurados:

\begin{tabular}{|l|l|}
\hline \multicolumn{1}{|c|}{ Promotor } & \multicolumn{2}{|c|}{ Defesa } \\
\hline $\begin{array}{l}\text { não existiu torpeza porque não existiu } \\
\text { vingança (inexistência de provas de que } \\
\text { as vítimas eram assaltantes) }\end{array}$ & $\begin{array}{l}\text { não existiu torpeza, apesar de ter } \\
\text { havido vingança, mas por motivo } \\
\text { relevante (existência de provas de que } \\
\text { as vítimas eram assaltantes) }\end{array}$ \\
\hline \multicolumn{2}{|c|}{ tese comum = não existiu torpeza } \\
\hline
\end{tabular}

Alguns jurados expressaram ter dúvidas, olhando desconfiados e com cenhos franzidos para o promotor e o defensor. Na sala secreta, o juiz reiterou que, por motivos diferentes, as partes pediam a mesma atitude dos jurados e disse que, ainda assim, eles não eram obrigados a acatar tal pedido. Contudo, acabou havendo uma votação única, para todos os quesitos, e a tese comum da defesa e da acusação foi acatada.

Este pareceu-me um jogo muito bem jogado pelo promotor e pela defesa, mas, ao mesmo tempo, bastante arriscado. Bem jogado porque, como a tese comum baseava-se numa dúvida - referente à existência ou não da vingança do réu sobre as vítimas - tanto os que o considerassem vingativo, quanto os que não o considerassem, poderiam chegar à mesma conclusão: exclusão da torpeza. O risco era o de algum jurado concluir ter havido vingança e considerar os homicídios duplamente qualificados. O juiz, sem dúvida, contribuiu para a efetivação do acordo, ao reiterar, com firmeza, a convergência das opiniões do promotor e do advogado quanto à inexistência de torpeza.

Outro fator que pesou no desfecho, segundo minha percepção, foi a própria figura do réu: homem branco, barba e cabelos grisalhos, meia idade, muitas rugas, estatura mediana, nem magro nem gordo, bem vestido, capanga pendurada num dos 
ombros, ar cansado e olhar triste. Durante seu interrogatório em plenário, relatou que, depois que foi expulso da PM, tornou-se balconista de padaria, motorista de táxi e, finalmente, caminhoneiro de uma empresa. Contou ter uma companheira, há 25 anos e seis filhos. Todos esses detalhes, provavelmente, entraram no jogo e tornaram-no absorvente, até o final, apesar do aparentemente cabal acordo feito nos bastidores.

Acordos, portanto, fazem-se presentes em muitos jogos e não necessariamente facilitam seu desenvolvimento e/ou abreviam seu término. Conforme vimos, especialmente em jogos de persuasão, não basta dois persuasores que, à princípio, deveriam estar em oposição, entrarem em acordo para que a persuasão comum se efetive. É preciso que cada um persuada bem, o que implica interagirem com os alvos da persuasão - jurados, no caso do Júri. Essa interação, nenhum acordo prévio garante, pois ela se faz "em cena" e está à mercê de múltiplos fatores a serem bem articulados $^{23}$.

\section{- Cria ordem e é ordem}

Desdobrando um pouco mais as características já apontadas, podemos afirmar que os julgamentos judiciais, em geral, e os processados pelo Júri, em particular, introduzem na confusão da vida e na imperfeição do mundo uma perfeição temporária e limitada.

Nos autos processuais e no transcorrer das audiências e sessões plenárias, a confusão dos acontecimentos - as famílias não nucleares e não monogâmicas, os trabalhos informais, a vida em favelas, a circulação de carros roubados e de armas de fogo, o analfabetismo, as gírias, as drogas, os bares e danceterias de bairros pobres não só é captada a partir de diversos olhares e apresentada em diferentes versões, como, temporária e limitadamente, é organizada, recortada e recortada numa elaboração tensa, regrada e linear, com base na qual desenvolvem-se argumentos e provas - de defesa e de acusação — os quais culminam numa sentença, também aparentemente perfeita, acabada e coerente ${ }^{24}$.

Conforme já apontou Castoriadis (1990: 125), as instituições sociais exercem uma tríplice função: estruturam as representações do mundo; designam as finalidades

\footnotetext{
$\overline{23}$ - A questão da importância do que se estabelece "em cena" é um dos principais pontos desenvolvidos no Capítulo 4.

24 - Nos próximos capítulos, será retomado o tema da percepção linear do tempo pelo Judiciário e a questão de, nos processos e procedimentos judiciais, os fatos da vida serem organizados e interpretados cronologicamente, a partir de nexos causais.
} 
das ações - o que deve e o que não deve ser feito - e estabelecem tipos de afetos característicos. Portanto, o Júri, enquanto uma das instituições de nossa sociedade, é alvo e ponto de partida de experiências sociais compartilhadas que, por sua vez, caracterizam a sociedade, permitindo a seus integrantes compreenderem -na, ordená-la, aceitarem-na como sua. Nesse mesmo processo, tais integrantes compreendem-se e aceitam-se (ou não) como participantes "da sociedade".

No Júri, representações de mundo são estruturadas por acusadores e defensores para, com elas, jurados aderirem a tais estruturas e, consequentemente, aos argumentos que as sustentam. Valores típicos das camadas sociais média e alta, por exemplo, surgem nos discursos de acusadores, defensores e até de testemunhas e dos próprios réus, como sinônimos de "vida boa" ou "correta" - ter família (nuclear, monogâmica, "unida"), trabalho (uma profissão formal que implique ser mão de obra qualificada), casa (de preferência própria, de alvenaria e não situada em favela), carro (também próprio, devidamente lacrado e licenciado e, de preferência, "da moda"), "cultura" (ser escolarizado, usar um português gramaticalmente correto) e "bons hábitos" (não usar drogas, não freqüentar bares e danceterias de bairros pobres etc). ${ }^{25}$ Essas percepções da vida numa grande metrópole, bem como outras relacionadas ao medo, à violência e às diferenças e proximidades sócio-econômicas aparecem como representações recorrentes, nos plenários.

Durante uma sustentação, disse um promotor: "Os Srs. já assistiram a documentários do Discovery Channel ou da National Geographic, em que predador e pesa andam lado a lado, antes do primeiro atacar a segunda? Nas favelas também é assim. Predador e presa andam juntos até o momento do bote." ${ }^{26}$ Jurados assinantes de TV a cabo, interessados em documentários de caráter científico e que entendem o nome em inglês do canal de TV mencionado, foram chamados a comparar o "mundo da criminalidade" com o "mundo animal".

Tipos de afetos característicos, portanto, são estabelecidos no Júri, como, por exemplo, considerar a vingança, por motivação "relevante", não definidora de torpeza

\footnotetext{
25 - Uma pesquisa da historiadora Martha de Abreu Esteves, com processos criminais de atentado ao pudor, estupro e rapto, ocorridos no Rio de Janeiro, entre 1900 e 1913, demonstra o quanto moças mães solteiras, de camadas populares, que viviam, portanto, uma realidade sócio moral diferente das de moças da elite - trabalhavam até tarde, andavam sozinhas nas ruas -, acabavam, por pressões de seus pais, patrões e fofoqueiras da vizinhança, abrindo processos judiciais contra os pais de seus filhos, nos quais, enquanto vítimas, reiteravam valores da elite, como a valorização dos trabalhos domésticos para as mulheres, em detrimento de outros trabalhos. Não fosse assim, sabiam que o Judiciário e "a" sociedade as transformariam em rés (Esteves, 1989).
} 
num assassinato, mas fator atenuante para o réu. Num caso em que se levanta esse tipo de discussão, o que mais importa são valores morais para que os jurados decidam o que socialmente legitima ou não uma pessoa matar outra.

Enfim, além de o Júri possuir regras que ordenam seu próprio funcionamento, as quais, uma vez desobedecidas, comprometem-no, ele também ordena aquilo com o que lida, ou seja, ele determina como, por quem e quando o poder de matar deve ser usado, de forma socialmente legítima.

\section{- Belo}

Assim como em qualquer jogo, também nos julgamentos pelo Júri, as regras que ordenam seu desenvolvimento estão previamente estabelecidas, mas o que imprime ritmo, harmonia e beleza única a cada "partida" é o modo como os jogadores fazem uso delas. Talvez, possamos comparar a distância existente entre as orientações do Código de Processo Penal ${ }^{27}$, esmiuçadas nos livros técnico-doutrinários, e o que ocorre em plenário, com a distância entre o registro de uma sinfonia, em uma partitura musical, e sua execução por uma orquestra.

Cada sessão é única, pois jamais repetem-se os mesmos elementos que a compõem. Até na hipótese impossível de um réu ir a Júri, uma segunda vez, pelo mesmo crime, e ser julgado no mesmo plenário, pelo mesmo Conselho do primeiro julgamento, diante dos mesmos juiz, promotor, defensor, testemunhas e assistentes, ainda assim, o tempo teria passado para todas essas pessoas e isso marcaria seus novos depoimentos, sua expressões e suas compreensões. O "colorido" da música seria outro.

Pelo que pude perceber das várias sessões às quais assisti, são múltiplos os fatores que determinam seu ritmo e sua harmonia e eles se fazem presentes desde os momentos iniciais, quando jurados chegam aos plenários e sentam-se para esperar o sorteio que determinará quais deles comporão o Conselho de Sentença e quais serão dispensados.

Numa dessas ocasiões ${ }^{28}$, estava eu, devidamente sentada à direita de quem entra, observando a chegada dos jurados, que sentavam-se à esquerda, quando entrou "no palco" uma funcionária. Primeiro ela observou, numa folha de papel que repousava sobre a mesa dos jurados, a "lista de presença" com os nomes dos 21 convocados. Ela

\footnotetext{
26 - 15/08/2001, das 12h às 16h45', Plenário 7 do $1^{\circ}$ Tribunal do Júri (Barra Funda).

27 - A seqüência completa desses "passos" encontrase no próximo capítulo.
} 
conferiu quantas assinaturas já havia — pois, à medida que chegavam, os jurados iam até essa mesa, assinar, sem que ninguém os orientasse. Então, com ar soberano, apesar de muito miúda, ela dirigiu-se a eles, postando-se de pé, exatamente diante da portinha divisória entre "palco" e "platéia". Com voz firme, de quem dá ordens indiscutíveis, explicou, objetivamente, quem deveria retornar para o próximo Júri, dali a um mês, e quem estava dispensado, por já ter cumprido a "quota". Jurados que estavam meio esparramados nas cadeiras foram se ajeitando, à medida que a funcionária prosseguia: "Eu não telefonarei para vocês, avisando-os do dia e da hora da próxima sessão, exceto se ela for cancelada, caso em que telefonarei na véspera. Portanto, anotem direitinho a data e a hora que estão escritas no quadro. Os faltosos, que não se justificarem, terão de pagar multa, conforme já sabem. E como não há dúvidas nem mais nada a dizer, isso é tudo."

Depois de sua retirada, a qual se deu com passos de marcha, havia um "clima" de maior atenção - e mesmo de tensão - entre os jurados. Suas posturas revelavam maior expectativa. A sessão não começara, oficialmente, mas já começara, oficiosamente, pois aquela funcionária, ao agir como uma autoridade, inaugurou o "tabuleiro" do jogo, ou a divisória entre "palco" e "platéia". Visivelmente, ela experimentou seu momento de glória, o qual, aliás, não foi o único naquela manhã, pois, no decorrer do julgamento, foi ela quem leu, para os jurados, trechos de algumas peças processuais, a pedido do promotor, o que fez como se fosse um arauto da justiça. A postura dessa funcionária influenciou o ritmo da sessão, bem como o modo de o juiz interrogar o réu — rajadas de perguntas secas - e de, depois, ler o relatório para os jurados - ar de quem já viu esse filme antes. O mesmo aplica-se às posturas do promotor - homem grande, com aparência impecável, um discurso retumbante e denso - e do defensor - mais franzino, porém firme e incisivo. O modo como cada um fez uso de seus tempos de fala e como foi esse uso imprimiu o ritmo e a harmonia do julgamento.

O equilíbrio tenso que pode se estabelecer entre argumentos e contraargumentos de réplicas e tréplicas; o silêncio e as intervenções do juiz para pontuar e esclarecer dúvidas; a expectativa crescente com que se chega ao desenlace secreto da votação dos quesitos são, todos, fatores que œmpõem o fascínio de boa parte dos julgamentos pelo Júri, ao menos para os que estão diretamente envolvidos na estratégia do jogo - especialmente promotor e defensor. Cabe registrar que isso não parece se

${ }^{28}$ - 16/08/2001, das 09h às 11 h35', Plenário 7 do $1^{\circ}$ Tribunal do Júri (Barra Funda) 
aplicar à maioria dos réus e de seus parentes. Suas participações tendem a ser mais a de objetos que estão em jogo do que a de jogadores. Eles sentem e expressam isso, conforme podemos perceber na entrevista a seguir.

$\Rightarrow \mathrm{Eu}^{29}$ : Quando foi julgado, o que o Sr sentiu ao entrar na sala e ficar sentado ali?

$\Rightarrow$ Réu: Vergonha. Pisar aqui é vergonhoso, sabe. É baixo. É ruim pisar aqui.

$\Rightarrow$ Eu: Por que é vergonhoso?

$\Rightarrow$ Réu: Porque a gente se sente um nada, entende? Um nada. A gente fica ali, prá ser mostrado.

$\Rightarrow(\ldots)$

$\Rightarrow$ Eu Quando o Sr. estava ali, o Sr. conseguiu acompanhar o que eles falavam?

$\Rightarrow$ Sr. S: Mais ou menos. O que eu sabia é que era a lei e que era certo o que estava acontecendo.

$\Rightarrow$ Eu: $E$ o que o Sr. achou de 7 pessoas serem chamadas para ouvir o que eles falavam e depois decidirem sobre sua vida?

$\Rightarrow$ Sr. S: Eu não achei nada. A lei manda assim, então é assim.

$\Rightarrow$ Eu: O Sr. acha que a lei mostra quem está sendo julgado de uma forma vergonhosa?

$\Rightarrow$ Sr. S: Eu não acho nada. [pausa longa, mãos entrelaçadas sobre as pernas e cabeça baixa]. Mas o que a gente sabe ninguém aqui sabe.

Por fim, os jurados são chamados a jogar segundo um duplo registro: o da sensibilidade e o da razão - "Os senhores são, neste momento, sete juízes e saibam que o juiz de direito também julga de acordo com ideologias. Ele primeiro lugar julga e depois, se necessário, busca razões para se justificar. Os jurados trazem para a Justiça a sua experiência e sensibilidade." ${ }^{30}$. Essa complexidade de fatores e de possibilidades de participação e interações confere ao Júri, enquanto jogo, características que, muitas vezes, atribuemse ao que é belo: “(...) tensão, equilíbrio, compensação, contraste, variação, solução, união e desunião. O jogo lança em nós um feitiço: é fascinante, cativante. Está cheio (...) de (...) ritmo e (...) harmonia." (Huizinga, 1980: 13).

\section{- Comunidade de jogadores X "outros"}

Outra característica comum a alguns tipos de jogos é o fato de eles propiciarem à comunidade de jogadores tornar-se permanente, mesmo terminado o jogo: “(...) a sensação de (...) partilhar algo importante, afastando-se do resto do mundo e recusando as normas habituais, conserva sua magia para além da duração de cada jogo. O clube pertence ao jogo tal como o chapéu pertence à cabeça" (op. cit: 15).

\footnotetext{
29 - 19/07/2001, 16h15', Plenário 8 do $\rho$ Tribunal do Júri (Barra Funda). Entrevista concedida pelo marido da ré, o qual havia sido julgado e absolvido, no mesmo plenário, um ano antes, como co-autor do mesmo crime pelo qual ela era julgada: homem negro, de 46 anos, embora aparentasse 60. Parecia um "caboclo velho". Permanecemos sentados, num canto da assistência, durante um intervalo de mais ou menos 10 minutos. A ré foi condenada a 12 anos de reclusão, do qual foram abatidos $2 / 3$, resultando 4 anos, dos quais diminuiu-se mais $1 / 3$, restando 2 anos e 8 meses em regime aberto.
} 
O refeitório exclusivo dos promotores do $1^{0}$ Tribunal do Júri; a sala em que se reúnem os procuradores; cursos e congressos específicos para juízes dessa instituição são apenas alguns exemplos do quanto o contato entre eles perpetua-se fora do espaço dos plenários, das salas de audiências e dos corredores dos tribunais. Esse tipo de comportamento comunitário, é muito comum entre jogadores que, por dominarem as regras de um mesmo jogo, acreditam também possuir outras afinidades.

Não bastasse o forte caráter corporativo dos profissionais da área jurídica, dentro dela multiplicam-se as associações de seguidores de uma mesma carreira magistrados, promotores, procuradores. No caso do Júri, tem-se, ainda, uma aproximação dos que nele atuam, em função da especificidade dos ritos e pelo fato de que são constantes os ataques ao caráter democrático da instituição, fazendo com que vários se unam em sua defesa, publicando artigos, organizando coletâneas, promovendo palestras e elaborando teses.

Nos próprios plenários do Júri, por tudo que já foi exposto, é bastante visível a separação entre "nós" - de dentro do jogo, com regras próprias, togas próprias, lugares demarcados, identidades e papéis definidos - e "outros" — de fora, anônimos, submissos às leis e costumes da vida cotidiana, meros observadores.

De modo amplo, compõem o grupo "nós", especialmente, os operadores técnicos - juízes, promotores, defensores, funcionários do tribunal e PMs - e, condicional e temporariamente, os jurados. Os "outros" são o réu, seus parentes e os assistentes das sessões.

Embora o réu seja, aparentemente, o centro das atenções, mais uma vez, percebe-se que ele não faz parte nem do grupo "nós" nem do grupo "outros". Ele é a razão de esses grupos estarem ali, mas não integra nenhum deles.

A separação "nós X outros" evidencia-se na hierarquia que promotor e defensor estabelecem, desde o momento inicial de suas falas, quando cumprimentam os presentes. Primeiro, prestam homenagens ao próprio grupo — "nós" —, a começar pelo juiz; depois, mencionam os "outros" e, geralmente, por fim, e já iniciando a argüição, saúdam os jurados. Eis uma saudação típica que, embora feita por um promotor, poderia, com as devidas adaptações, advir de um defensor: "Exmo Sr. Presidente deste Tribunal do Júri, Dr. (...). Pelo 2 dia consecutivo, tenho a honra de trabalhar com Vossa Excelência, cuja segurança, simpatia e cordialidade conheço e admiro de várias outras sessões que compartilhamos. Aos defensores, embora desconheçaos, com certeza devem estar

30 - idem. 
representando muito bem a $O A B$. O MP, portanto, saúda a $O A B$. Aos funcionários deste Tribunal, sem os quais as sessões não se processariam, aos PMs, bravos cidadãos que garantem a nossa segurança neste plenário e fora dele, a todos os presentes que nos brindam com sua atenção, os meus cumprimentos. Aos Senhores jurados, desde já, adianto que explicitarei os fatos da maneira mais simples e didática possível, pois coloco-me no lugar de Vossas Excelências e imagino como eu me sentiria sendo chamado a atuar, da noite para o dia, numa área profissional que não é a minha e da qual nada conheço. Sei que é difícil para leigos analisar um processo judicial e decidir. Respeito muito o que fazem. ${ }^{311}$

Outro bom exemplo, também advindo das saudações de um promotor: "Excelência, é com honra, respeito e prazer que me dirijo a um juiz tão competente, com tamanho conhecimento das ciências humanas e jurídicas, militante da justiça (...); homem de realização da justiça". Dirigindo-se ao defensor, disse: "Nobre colega da defesa, embora estejamos em lados opostos, temos um ponto em comum: a busca da justiça". Aos funcionários e PMs, agradeceu "a seriedade e dedicação com que executam suas tarefas". Aos assistentes do plenário: "Um dos modos de se examinar o desenvolvimento de uma nação é examinar como essa nação realiza justiça. E, no Júri, isso pode ser claramente observado." Finalmente, ao cumprimentar os jurados, qualificou-os como "(...) representantes da comunidade. E lembrou: Na origem secular do júri - leitura da pauta em praça pública - a comunidade julgava acusados de violar as leis. (...) É um serviço gratuito porque é uma relevante missão social. 32

Essas saudações de promotores e advogados identificam, posicionam, designam os papéis. No primeiro dos exemplos citados, o promotor afirma "compartilhar" as sessões com o juiz e, em seguida, evoca a instituição que ele representa - o Ministério Público - para, em seguida, saudar a instituição representada pelo advogado - a OAB —, compartilhando, assim, com esse, um papel institucional. Aos funcionários do Tribunal e aos PMs é atribuído um papel instrumental, de fazer a estrutura funcionar e, aos assistentes, confere-se a função de observadores. Certa ambigüidade está na saudação aos jurados, pois, ao mesmo tempo que o promotor diz respeitá-los, identifica-os como não mais que leigos esforçados. Esse mesmo promotor, no decorrer dessa sessão, voltaria a dizer: "Eu estudei horas e horas este processo, ao passo que os Srs. não o estudaram sequer um minuto, o que dificulta ainda mais o trabalho que devem desempenhar. Além do estudo, a prática também me faz concluir que a versão do réu é duvidosa".

31 - 05/09/2001, das 12h10' às 17 h22', Plenário 9 do $1^{\circ}$ Tribunal do Júri (Barra Funda).

32 - 19/07/2001, \pm 13 h30', Plenário 8 do $1^{\circ}$ Tribunal do Júri (Barra Funda). 
A maioria dos operadores técnicos costuma dizer aos jurados que eles desfrutam de um status transitório e especial e, por isso mesmo, devem se portar de modo também especial. Assim manifesta-se um juiz: "Os senhores devem manter uma posição semelhante à minha, de neutralidade. Não devem deixar transparecer emoções e opiniões.(...). A partir de agora, os senhores passam a integrar o Poder Judiciário, na função de juízes". 33

“ (...). O que se espera dos senhores é que utilizem aqui sua experiência de vida, sua sensibilidade, a visão real do que ocorre nos nossos dias, mas que o façam com introspecção, consultando suas consciências, em estado de meditação. Enfim, trata-se de um compromisso que, como cidadãos, Vossas Excelências têm com a realidade social (...).,"34

No segundo dos exemplos de saudação, o promotor identifica o juiz com um sábio e a "realização da justiça" com o exercício dessa sabedoria. O advogado é posicionado no mesmo patamar do promotor - colegas - pois ambos buscam a justiça. Novamente, funcionários e PMs são tidos como tarefeiros e a assistência aparece como observadora e aprendiz da justiça. Os jurados entram como "representantes-missionários" da comunidade. Todos, enfim, têm seu lugar e seu papel definidos ${ }^{35}$.

\section{- Festa}

Assim como o jogo, também a festa implica uma suspensão da vida cotidiana e cria um tempo e um espaço artificiais. Se ainda partirmos do pressuposto de que há uma relação, senão direta, ao menos indireta, entre festa da representação entendendo-se representação enquanto exibição de poder - e legitimação do poder, uma das deduções possíveis é a de que quanto mais pomposa for uma festa da representação de um Estado, mais ela convencerá de que seu soberano é poderoso (Geertz, 1991).

A representação, ao fazer com que os súditos, consensualmente, atribuam poder ao soberano, constrói sua legitimidade. E como o poder só se legitima quando é concedido, e não roubado ou usurpado, é no processo de representação festiva que se dá sua efetiva legitimação.

\footnotetext{
${ }_{33}$ - Fala do juiz aos jurados, no início da sessão ocorrida em 05/09/2001, das 12h10' às 17h22', no Plenário 9 do $1^{\circ}$ Tribunal do Júri (Barra Funda).

34 - Fala do promotor ao saudar os jurados, antes do início de sua sustentação oral: 15/08/2001, das $12 \mathrm{~h}$ às $16 \mathrm{~h} 45^{\prime}$, Plenário 7 do $1^{\circ}$ Tribunal do Júri (Barra Funda).

35 - A análise dessa hierarquia é retomada e aprofundada no próximo capítulo.
} 
Há festa no Júri: no uso das togas, na ocupação regrada do tempo e do espaço e no sorteio que determina quais dentre os jurados convocados serão juízes e, portanto, desfrutarão, durante algumas horas, da posição de soberanos. A eles, temporariamente, é concedido o poder de representarem o Estado e as normas sociais. Mesmo os jurados dispensados são brindados com o reconhecimento da "notória idoneidade".

O Estado, por sua vez, ao conceder o poder da "notória idoneidade" legitima-se. Cada vez que um cidadão participa do ritual do Júri, crendo-se notoriamente idôneo, e julga alguém acusado de não sê-lo, é o Estado que, soberano, está ditando quem é quem. Como já vimos e aprofundaremos nos próximos capítulos, nesse ritual de concessão de poderes, promotores e defensores exibem hierarquias e modos de viver e morrer, social e fisicamente. A "notória idoneidade" atribuída aos jurados é por eles aceita e praticada ao decidirem, com base nela, se o réu também a possui ou não.

Em outras palavras, nessa exibição da lei, da norma e de sua aplicação aos "casos concretos" há um jogo persuasivo em que operadores técnicos e leigos, mutuamente, legitimam os poderes que exercem no Júri e na sociedade. Enfim, o que está em espetáculo no Júri é, ao mesmo tempo, a exibição e a legitimação do Estado, da lei, de seus representantes e de certos padrões e valores sociais.

\section{- Sistema de crenças}

Encerrando o elenco de características dos jogos que também pode ser percebido no Júri, permitindo-nos entender melhor sua dinâmica, tratemos do Sistema de Justiça Criminal, do qual fazem parte os julgamentos processados pelos Tribunais do Júri.

É possível pensá-lo como um sistema de crenças e práticas em que, apesar de haver uma consciência - geralmente parcial - do caráter fictício de seus procedimentos, nem por isso trata-se de uma fraude inventada e mantida por "incrédulos" operadores técnicos com vistas a dominar "crédulos" jurados, réus e mesmo "a" sociedade. O Sistema de Justiça Criminal e o Júri só existem porque há uma credulidade generalizada e compartilhada, por todos, na validade de seus procedimentos e resultados ou, ao menos de que, por enquanto, não há como prescindir deles. ${ }^{36}$.

\footnotetext{
36 - A antropóloga Yvonne Maggie trabalhou esse tema, ao analisar casos criminais que envolviam feitiços e que ocorreram entre 1890 e 1940, mo Brasil, especialmente no Rio de Janeiro. Uma de suas conclusões é a de que juízes, acusados, testemunhas e peritos partilhavam premissas culturais, categorias e expressões, de que todos acreditavam, por um
} 
Façamos um parênteses para lembrar uma lição de Lévi-Strauss que pode nos auxiliar nessa abordagem do Sistema de Justiça Criminal enquanto sistema de crenças: “(...) um indivíduo, consciente de ser objeto de um malefício, é intimamente persuadido, pelas mais solenes tradições de seu grupo, de que está condenado; parentes e amigos partilham dessa certeza. Desde então a comunidade se retrai: (...), o corpo social sugere a morte à infeliz vítima, que não pretende mais escapar àquilo que ela considera como seu destino inelutável. (...). A integridade física não resiste à dissolução da personalidade social." (Lévi-Strauss, 1996: 193-194).

Embora essas passagens permitam ao autor introduzir a tese de "(...) que a eficácia da magia implica na crença da magia", não parece abusivo extrapolá-la para a reflexão de que a eficácia do Júri implica na crença do Júri. Réus, "as mais solenes tradições de seu grupo", parentes e amigos, a comunidade que julga — jurados —, todos são responsáveis, mais do que por sentenças condenatórias ou absolutórias, pela eficácia do próprio sistema de julgamento.

Segundo Lévi-Strauss, são três os aspectos complementares da crença: o feiticeiro crê na eficácia de suas próprias técnicas; os enfeitiçados crêem no feiticeiro e no feitiço; e a opinião coletiva forma "uma espécie de campo de gravitação" entre feiticeiros e enfeitiçados (idem : 194-195). Paralelamente, para que o sistema do Júri tenha alguma eficácia, os feiticeiros da lei — juiz, promotores, defensores e funcionários - acreditam em suas técnicas; os enfeitiçados pela lei — jurados, réu, seus parentes e amigos acreditam nela e em seus operadores; e a opinião coletiva relaciona, define e situa uns e outros. Portanto, assim como para Lévi-Strauss "a situação mágica é um fenômeno de consensus", podemos afirmar que a situação dos julgamentos pelo Júri também o é.

Lembra ainda, Lévi-Strauss, que certas experiências vividas pelos indivíduos, como a das doenças, são "(...) intelectualmente informes e afetivamente intoleráveis" e que elas tendem a assim prosseguir "a não ser que se incorporem a tal ou qual esquema presente na cultura do grupo e cuja assimilação é o único meio de objetivar os estados subjetivos, (...)" (ibidem: 198). Tal afirmação é válida para experiências vividas como violentas, pois a própria percepção individual do que é ou não violento depende de referenciais coletivos, relacionados à faixa etária, sexo, grau de escolaridade, religião, renda, local de moradia, etnia e outras variáveis sócio-econômicas (Cardia: 1999). Um sistema de crenças, portanto, orienta e constrói percepções e atitudes dos que dele participam, ao mesmo

lado, na existência de pessoas que usavam mal os preceitos do espiritismo e, por isso, deviam ser castigadas, e por outro, na validade, legitimidade e legalidade do bom uso desses preceitos. (Maggie, 1992). 
tempo que esses legitimam o sistema a cada nova percepção e atitude orientada, construída e julgada.

A cada sessão de Júri, em que se repetem determinados esquemas — sorteio de jurados; comportamento hierarquizado dos participantes em plenário; interrogatório do réu; debates entre promotor e defensor; incomunicabilidade entre os jurados; votação de quesitos e definição de uma sentença - um sistema de julgamento está orientando percepções e atitudes individuais dos participantes, permitindo-Ihes "objetivar estados subjetivos, formular impressões informuláveis, e integrar experiências inarticuladas" (Lévi-Strauss, 1996: 198). Simultaneamente, tais percepções e atitudes revigoram a existência do próprio Júri , atribuindo-lhe sentido.

A maioria dos interrogatórios de réus e das sustentações orais de promotores e defensores, que observei, pode ser caracterizada pelas seguintes palavras de LéviStrauss: “(..) antes que reprimir um crime, os juízes [promotores e defensores, eu acrescentaria] procuram (...) atestar a realidade do sistema que o tornou possível. (...). $O$ acusado, preservado como testemunha, traz ao grupo uma satisfação de verdade, infinitamente mais densa e mais rica do que a satisfação de justiça que teria proporcionado a sua execução. (...) o acusado participa com sinceridade e (...) fervor do jogo dramático que se organiza entre seus juízes e ele. (...). Para ele também, a coerência do sistema, e o papel que lhe é assinalado para estabelecê-la, (...) têm um valor (...) essencial."(idem: 1996: 201 - grifo meu)

Essas passagens fazem pensar em cada réu como uma verdadeira "encarnação da criminalidade", mesmo que o desfecho do julgamento seja absolutório. Sem seu corpo presente em plenário, sem o juiz a interrogá-lo e sem promotor e defensor a contextualizarem a criminalidade através das estórias narradas, ela nada mais seria que um conjunto difuso de sentimentos e de representações sem coerência. Seja quando o réu confessa sua culpa ou a nega, seja quando promotor e defensor fazem seus argumentos convergirem ou divergirem, o que está em jogo e que sustenta o jogo é o fato de esses personagens substantivarem o Sistema de Justiça Criminal e a noção de criminalidade.

Ao definir os três elementos indissociáveis do que denomina "complexo xamanístico", Lévi-Strauss afirma: "Esta fabulação de uma realidade em si mesma desconhecida, feita de procedimentos e de representações, é afiançada numa tripla experiência: a do próprio xamã (...); a do doente, (...); a do público, cujo arrebatamento sofrido, e a satisfação intelectual e afetiva que retira, determinam uma adesão coletiva que inaugura, ela própria, um novo ciclo." E completa: "As experiências do doente representam o aspecto menos importante do sistema." (op. cit: 207) 
Novamente, essas passagens sugerem a importância de um sistema de crenças para a compreensão de uma realidade que seria opaca sem personagens e histórias que lhe dessem sentido - fabulação. Por isso, mais do que saber se o réu cometeu ou não o crime de que é acusado, importa o modo como ele - através das versões do promotor, do defensor e de sua própria - permite ao grupo articular uma reflexão circunstanciada sobre a criminalidade e os valores que tornam certos atos socialmente legítimos ou ilegítimos.

Referindo-se, diretamente, à eficácia dos feiticeiros, a seus sucessos e fracassos ao curar doentes, Lévi-Strauss afirma: "Quesalid" ${ }^{37}$ não se tornou um grande feiticeiro porque curava seus doentes, ele curava seus doentes porque se tinha tornado um grande feiticeiro.(...). É, de fato, na atitude do grupo, bem mais que no ritmo dos reveses e dos sucessos, que é necessário procurar a verdadeira razão da derrocada dos rivais de Quesalid. (...). O fracasso é (...) função de um outro fenômeno: o desaparecimento do consensus social, (...). O problema fundamental é, pois, o da relação entre um indivíduo e o grupo, ou, ainda, mais exatamente, entre um certo tipo de indivíduos e certas exigências do grupo." (op. cit: 208)

Em relação ao Júri e, especialmente, à eficácia dos discursos de promotores e defensores em plenário, podemos afirmar que um promotor não se torna um grande acusador porque condena muitos réus e que um advogado não se torna um grande defensor porque absolve outros tantos. Eles condenam ou absolvem com eficácia porque já se tornaram grandes oradores do Júri e isso, por sua vez, decorre menos de "dons individuais" - conforme afirmam tantos doutrinadores - do que do fato de estarem sintonizados - "em consenso" — com as expectativas dos jurados.

Mergulhando, um pouco mais, na psicanálise, Lévi-Strauss trabalha com o conceito de $a b$-reação ${ }^{38}$, afirmando que o espetáculo oferecido por um grande xamã a seus doentes e a seu auditório é mais do que o de reproduzir ou representar certos acontecimentos perturbadores para esses. O xamã "(...) os revive efetivamente em toda sua vivacidade, originalidade e violência. $E$ (...), ao termo da sessão, ele retorna ao estado normal". (op. cit: 209).

Conforme veremos, nos próximos capítulos, não temos nas grandes performances de oradores do Júri, apenas reprodução e representação de crimes perturbadores ou, ainda, fiéis relatos da "verdade dos fatos". Tampouco temos uma

\footnotetext{
37 - Feiticeiro Kwakiutl, da região de Vancouver, Canadá, cuja autobiografia foi parcialmente recolhida e traduzida por Franz Boas.

38 - Descarga emocional experimentada por um indivíduo na qual ele revive um acontecimento traumático e, ao fazê-lo, liberase de uma repressão a que estava submetido, em decorrência de tal acontecimento.
} 
simples imposição de valores "burgueses", por parte de operadores técnicos e jurados, a réus de "classes trabalhadoras". As performances dos oradores do Júri só são grandiosas e arrebatam os jurados, os assistentes e o próprio orador quando elas desencadeiam uma ab-reação, ou seja, quando, ao término da fala do orador, predomina a sensação de que ele elaborou e organizou com tamanha intensidade e pertinência os acontecimentos relatados, que possibilitou a todos transportarem-se para a situação originária da perturbação criminosa, restando então superá-la e retomar a normalidade da vida, sentenciando o réu.

Ainda tratando dessa essencial relação entre xamã e grupo, Lévi-Strauss discorre sobre os pensamentos "normal" e "patológico", os quais considera presentes e complementares, em todas as sociedades: "Em presença de um universo de que está ávido de compreender, mas do qual não chega a dominar os mecanismos, o pensamento normal reclama sempre seu sentido às coisas, que o recusam; ao contrário, o pensamento dito patológico, extravasa de interpretações e de ressonâncias afetivas, com as quais está sempre pronto a sobrecarregar uma realidade, que seria de outro modo deficitária. (...) o pensamento normal sofre sempre de uma carência de significado, ao passo que o pensamento dito patológico (...) dispõe de uma pletora de significante. (...) é necessário que, por uma colaboração entre a tradição coletiva e a invenção individual, se elabore e se modifique continuamente uma estrutura, isto é, um sistema de oposições e de correlações que integre todos os elementos de uma situação total onde feiticeiro, doente e público, representações e processos, encontram cada qual o seu lugar. É necessário que, do mesmo modo que o doente e o feiticeiro, o público participe, ao menos em certa medida, da ab-reação, (...)". (op. cit: 210).

Nesses ensinamentos de Lévi-Strauss, outra questão pertinente ao Júri encontra caminho para uma análise mais profunda. É a da oposição entre os denominados conhecimento técnico, a princípio dominado pelos operadores do direito, e o conhecimento do senso comum, prevalecente no modo de os jurados leigos julgarem. Tanto os defensores quanto os detratores do Júri costumam, além de apresentar esses conhecimentos como opostos, compará-los para concluir qual o mais adequado. Os defensores do Júri afirmam que a riqueza da instituição repousa, justamente, na utilização, pelos jurados, de "(...)sua experiência de vida, sua sensibilidade, a visão real do que ocorre nos nossos dias." 39 Os detratores do Júri repudiam esse "amadorismo" e propugnam a exclusão de juízes leigos, por considerarem a precisão da análise técnica garantia de maior justiça. Poucos são os que percebem a complementaridade entre os

\footnotetext{
$\overline{39}$ - Palavras do promotor, durante sustentação oral em 15/08/2001, às $13 \mathrm{~h} 45^{\prime}$, Plenário 7 do $1^{\circ}$ do Júri.
} 
dois tipos de "conhecimento" e o quanto eles, em si, não são puros: "(..) saibam que o juiz de direito também julga de acordo com ideologias. Ele primeiro julga e depois, se necessário, busca razões para se justificar. Os jurados trazem para a Justiça a sua experiência e sensibilidade." 40

O mais importante, contudo, é perceber que apenas o "pensamento normal" mais típico dos operadores técnicos do direito - não domina os mecanismos da criminalidade, e "o pensamento patológico", por sua vez, com suas "interpretações e ressonâncias afetivas" não se sustenta num conjunto de procedimentos que se pretende objetivo e racional. "Diversamente da explicação científica, não se trata, pois, de ligar estados confusos e inorganizados, emoções e representações, a uma causa objetiva, mas de articulá-los sob a forma de totalidade ou sistema." (Lévi-Strauss, 1996: 211)

Se considerarmos operadores técnicos e réu como um par de opostos, assim como Lévi-Strauss considerou o par feiticeiro-doente, poderemos afirmar que esse par “(...) encarna para o grupo, de modo concreto e vigoroso, um antagonismo próprio a todo pensamento, mas cuja expressão normal permanece vaga e imprecisa"(idem). E, assim como a cura põe em relação feiticeiro e doente, reunindo-os numa experiência total, os julgamentos pelo Júri põem em relação operadores técnicos e réus, permitindo a esses, a jurados, funcionários, PMs e assistentes participar e acreditar no Sistema de Justiça Criminal e nos valores que sua dinâmica permite reiterar.

\section{?? ?}

Este capítulo teve por meta iniciar a discussão do Júri enquanto um jogo, demonstrando que esse conceito, mais do que um recurso metafórico é um instrumento analítico cujos elementos permitem levantar questões, as quais permeiam esta tese e encontram-se aprofundadas em todos os demais capítulos.

No próximo, continuaremos trabalhando o conceito de jogo, não mais através da análise de suas características, mas examinando um jogo destinado a adolescentes e adultos e disponível nas principais lojas de brinquedos do Brasil. Ele simula o ritual dos julgamentos pelo Tribunal do Júri e chama-se Veredicto. Sua descoberta foi-me de tal forma inspiradora que, não fosse por ela, o rumo teórico desta tese, provavelmente, seria outro.

\section{???}

40 - idem. 


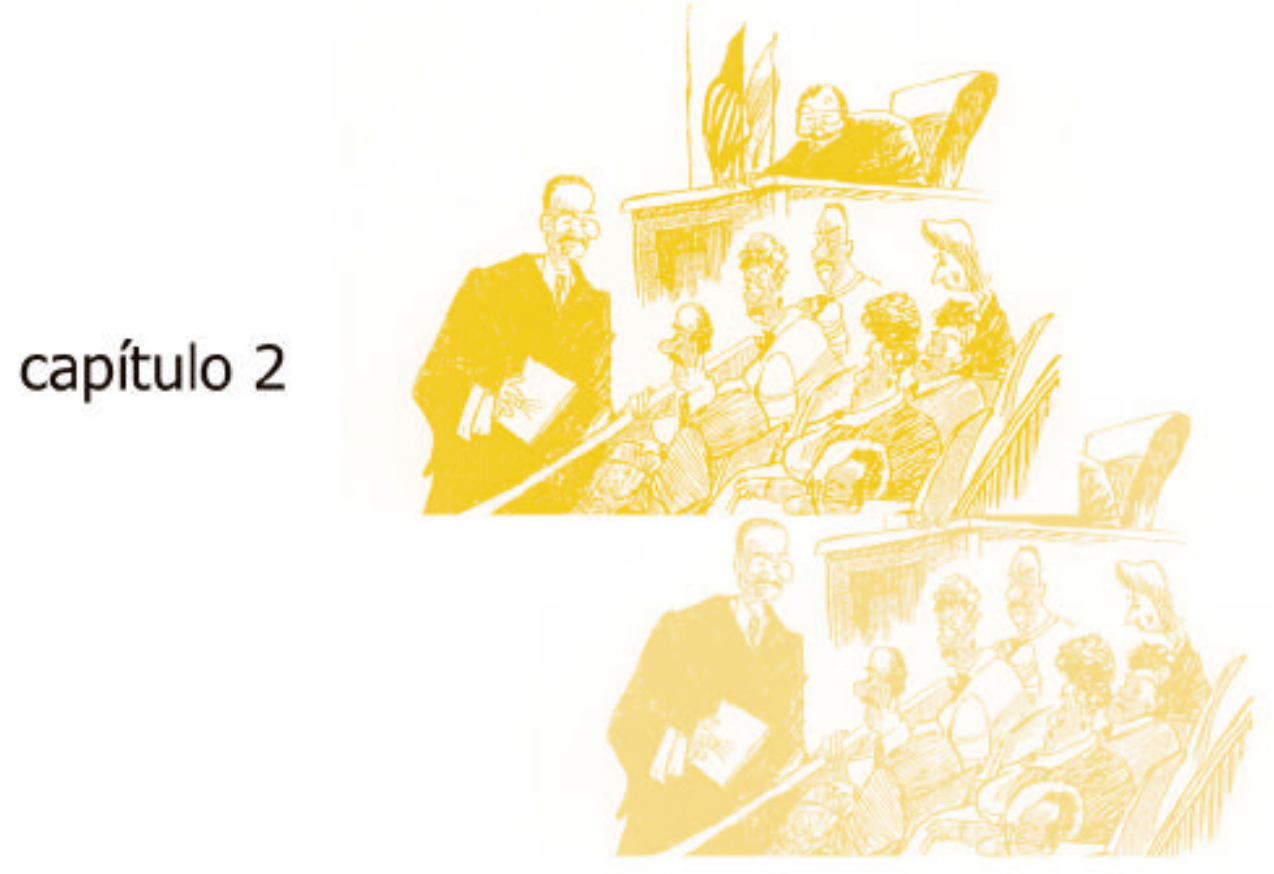




\section{JOGO VEREDICTO}

\section{- Introdução}

Descobrir o jogo Veredicto, por acaso, com a tese já em andamento, representoume a oportunidade de articular idéias até então dispersas e de perceber o próprio conceito de jogo, não como mero recurso de linguagem, mas enquanto instrumento de promissora rentabilidade analítica.

Devido a essa instigação intelectual, neste capítulo analisaremos alguns elementos da lógica do jogo Veredicto, bem como faremos comparações entre eles e aspectos do Júri "real". A intenção não é indicar em que pontos o primeiro "simula" mal o segundo, mas verificar como o primeiro interpreta o segundo e por que, ao fazê-lo, tanto omite quanto enfatiza procedimentos dos julgamentos "reais".

Especial atenção será dada ao ponto para o qual Veredicto e Júri parecem confluir: a construção de narrativas à respeito do crime e do suposto criminoso, mais para legitimar ou não o assassinato do que para constatar sua ocorrência.

Pretendemos, enfim, demonstrar que, de uma maneira peculiar, o jogo Veredicto "lê" o Júri, reiterando serem as sessões de julgamento um jogo de narrativas persuasivas que se faz "em ato" e na dependência da habilidade e sorte dos jogadores. 


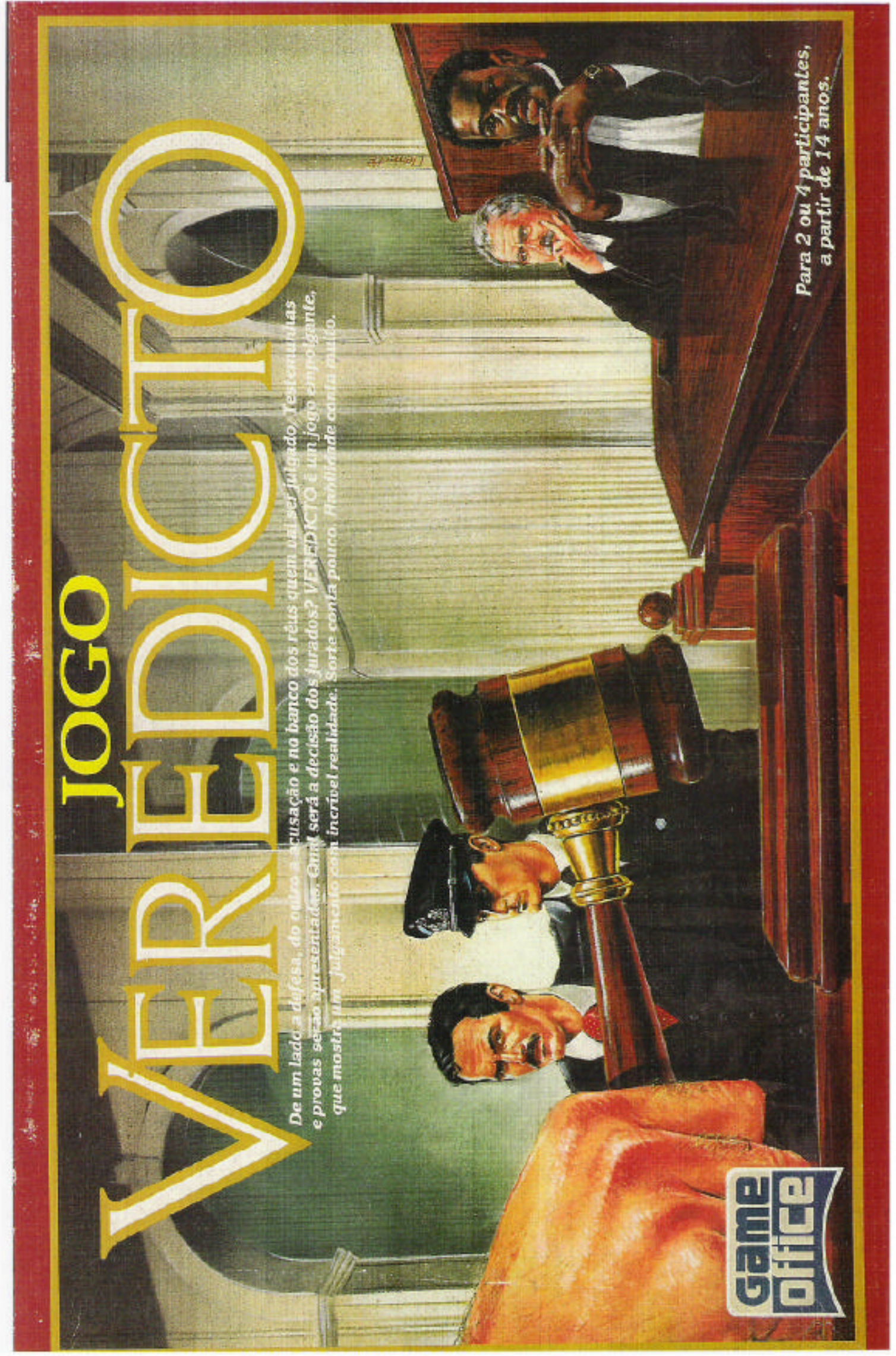




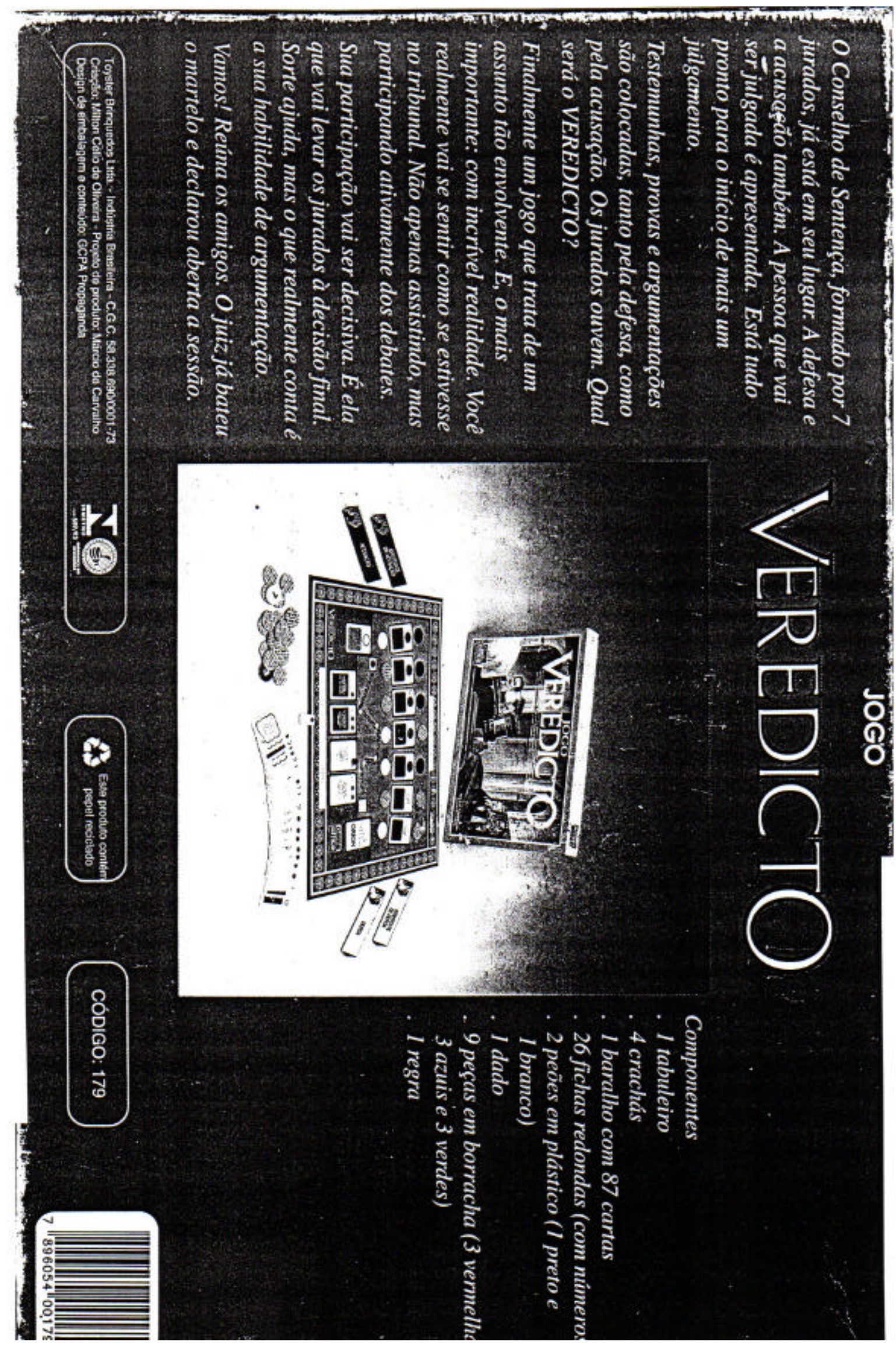




\section{- Apresentação do jogo: ilustração e dizeres da caixa}

O desenho que ilustra a tampa da caixa, pintado com cores sóbrias, sugere que o jogo trata de algo sério. Essa ilustração divide se em 4 planos.

No primeiro, que ocupa o canto inferior esquerdo, a mão de um juiz segura um martelo de madeira e metal, prestes a ser batido num apoio, também de madeira, anunciando algum momento importante do julgamento; provavelmente, o do Veredicto.

No segundo plano, à direita do martelo, dois homens togados estão sentados, compartilhando a mesma mesa. Um é negro, barbudo e jovem, e outro é branco, com bigode e cabelos grisalhos. Representam, provavelmente, o promotor de justiça e o advogado de defesa. Nada, porém, indica quem é quem. O negro olha em direção ao juiz, com expectativa, enquanto o branco olha para o réu, com preocupação. Tanto uma expressão quanto outra caberiam no rosto de um acusador ou de um defensor.

No terceiro plano, entre a mão do juiz e o martelo, estão o réu e um policial, em pé. O réu é branco, relativamente jovem, com cabelo e bigode escuros, veste um terno preto e uma gravata vermelha. Também olha em direção ao juiz, com certa desconfiança e expectativa - uma das sobrancelhas está levantada -, enquanto o policial, branco, de terno e quepe escuros, vigia o réu, bem de perto.

No quarto e último plano, que ocupa toda a metade superior da tampa, desenhos de colunas e arcos, em tons cinzentos, conferem ao ambiente a imponência que se espera encontrar num tribunal.

Jurados não estão representados, nem testemunhas, tampouco espectadores e funcionários. Uma conclusão possível é a de que o ponto de vista de quem olha essa ilustração tanto pode ser o do juiz quanto o dos jurados. Talvez, mais o dos jurados, pois a mão do juiz faz imaginá-lo à esquerda de quem observa a cena de frente. Seja como for, fazendo jus ao nome do jogo, a ilustração convida o observador a se identificar com quem dará o Veredicto.

Uma primeira e superficial observação dessa ilustração, faz lembrar que os prováveis promotor e advogado retratados estão sentados lado a lado, o que não ocorre, atualmente, nos plenários dos cinco Tribunais do Júri de São Paulo, conforme já apontamos, no capítulo anterior ${ }^{1}$. O réu — perfil de homem classe média, maduro, bem vestido, branco e de olhar altivo - também discrepa da maioria daqueles que se pode

\footnotetext{
1 - No Capitulo 4, em que é trabalhado o aspecto teatral do Júri, há outras reflexões sobre o plenário enquanto palco, no qual cada espaço ganha significado, seja pela composição dos
} 
observar nas atuais sessões paulistanas de Júri — homens de camadas populares, vestidos com simplicidade, jovens, mulatos, mais acabrunhados do que altivos.

Por fim, o policial do desenho também não é o típico policial militar que acompanha as sessões paulistanas do Júri, pois esse traja uniforme cinza e não usa quepe no plenário. Portanto, posições cênicas e figuras representadas na caixa não são um retrato fiel do que se observa nos Júris de São Paulo, mas importa menos tal fidelidade e mais a mensagem de que as sessões de julgamento são tão plenas de elementos lúdicos - oposição e competição, suspense, empolgação, acaso e habilidade - que, literalmente, inspiraram um jogo. Essa mensagem, por sinal, está grafada, em palavras, na tampa, abaixo do nome Veredicto: "De um lado a defesa, do outro a acusação e no banco dos réus quem vai ser julgado. Testemunhas e provas serão apresentados. Qual será a decisão dos jurados? VEREDICTO é um jogo empolgante que mostra um julgamento com incrível realidade. Sorte conta pouco. Habilidade conta muito."

As duas frases finais, ao mesmo tempo que apontam os fatores decisivos no jogo — habilidade e sorte - indicam qual deles prepondera - habilidade —, ou seja, mais do que contar com o acaso, cabe aos jogadores dominar uma estratégia argumentativa e agir em função dela.

A parte de baixo da caixa do jogo, em preto-e-branco, apresenta uma foto do tabuleiro aberto, com suas respectivas peças posicionadas e elencadas, juntamente com outros dizeres, dentre os quais: "O Conselho de Sentença, formado por 7 jurados, já está em seu lugar. A defesa e a acusação também. A pessoa que vai ser julgada é apresentada. Está tudo pronto para o início de mais um julgamento".

Conforme pontuou Huizinga, quando o "círculo mágico" se fecha, com todos seus elementos devidamente posicionados, o jogo tem início. O preenchimento dos "lugares de cada um" - de jurados, defesa, acusação e réu - demarca o início de um tempo e de um espaço artificiais que, por sua vez, existirão enquanto valerem e forem obedecidas regras especialmente elaboradas para orientá-los.

Outros dizeres do fundo da caixa são: "Finalmente um jogo que trata de um assunto tão envolvente. E, o mais importante: com incrível realidade. Você realmente vai se sentir como se estivesse no tribunal. Não apenas assistindo, mas participando dos debates. Sua participação vai ser decisiva. É ela que vai levar os jurados à decisão final. Sorte ajuda, mas o que realmente conta é a sua habilidade de argumentação. Vamos! Reuna os amigos. O juiz já bateu o martelo e declarou aberta a sessão"(grifos meus).

elementos cênicos — disposição e tipo do mobiliário, degraus, janelas, tamanho das salas, cores das paredes etc - seja pela ocupação e uso que os atores fazem desses elementos. 
Apesar, portanto, de a ilustração da tampa posicionar o observador como alguém que não é acusador, defensor, juiz ou réu, esses dizeres indicam tais posições como privilegiadas. A mensagem é a de que participar dos debates é participar decisivamente, levando os jurados à decisão final. Joga, portanto, quem argumenta e "brinca" de usar o poder de persuasão. Veremos, contudo, que, assim como ocorre nas sessões de Júri, a lógica do Veredicto demonstrará que tanto arguidores quanto alvos das argüições jurados - formam um par indissociável, pois é da interação entre eles que depende o Veredicto. 

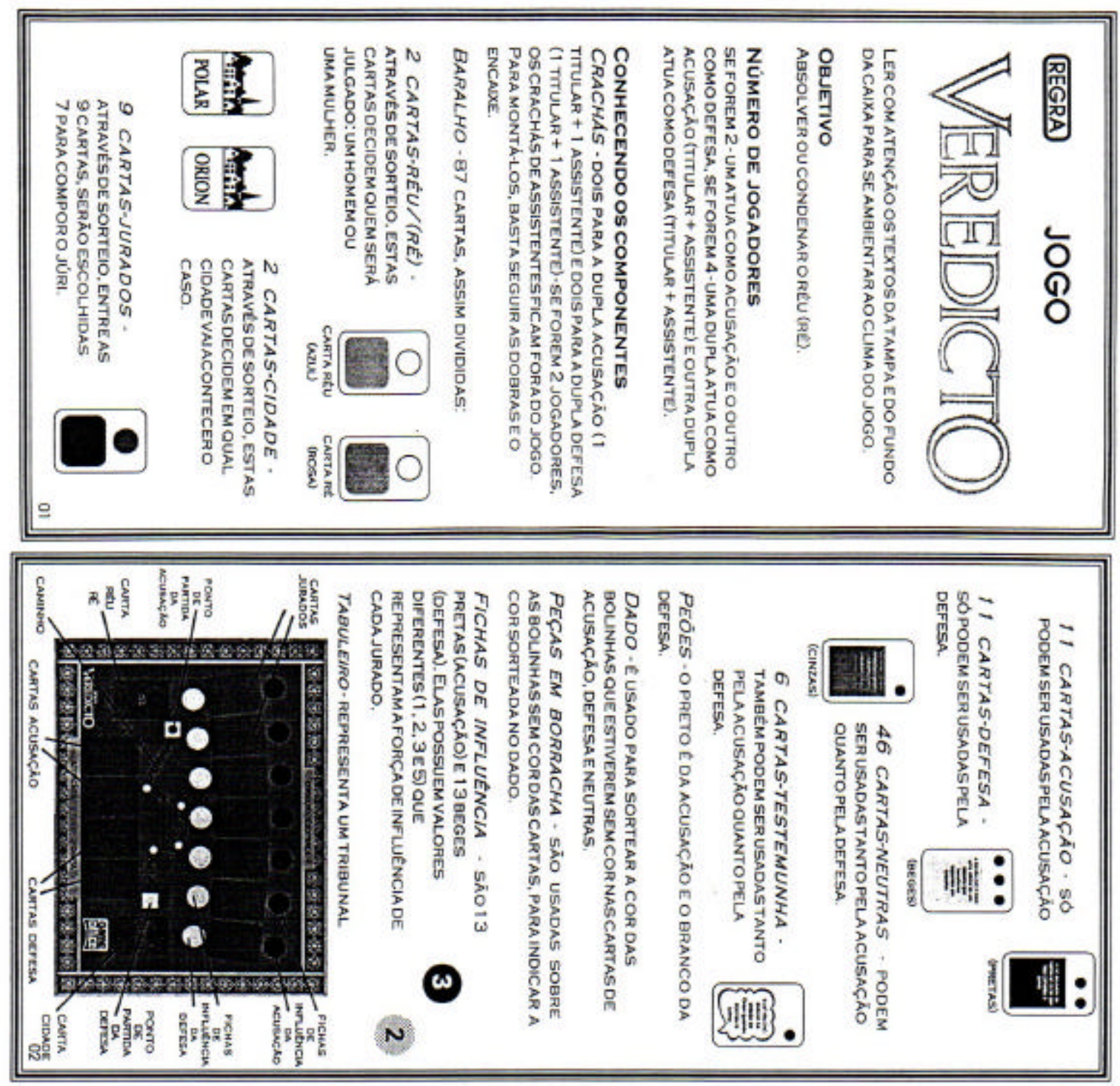

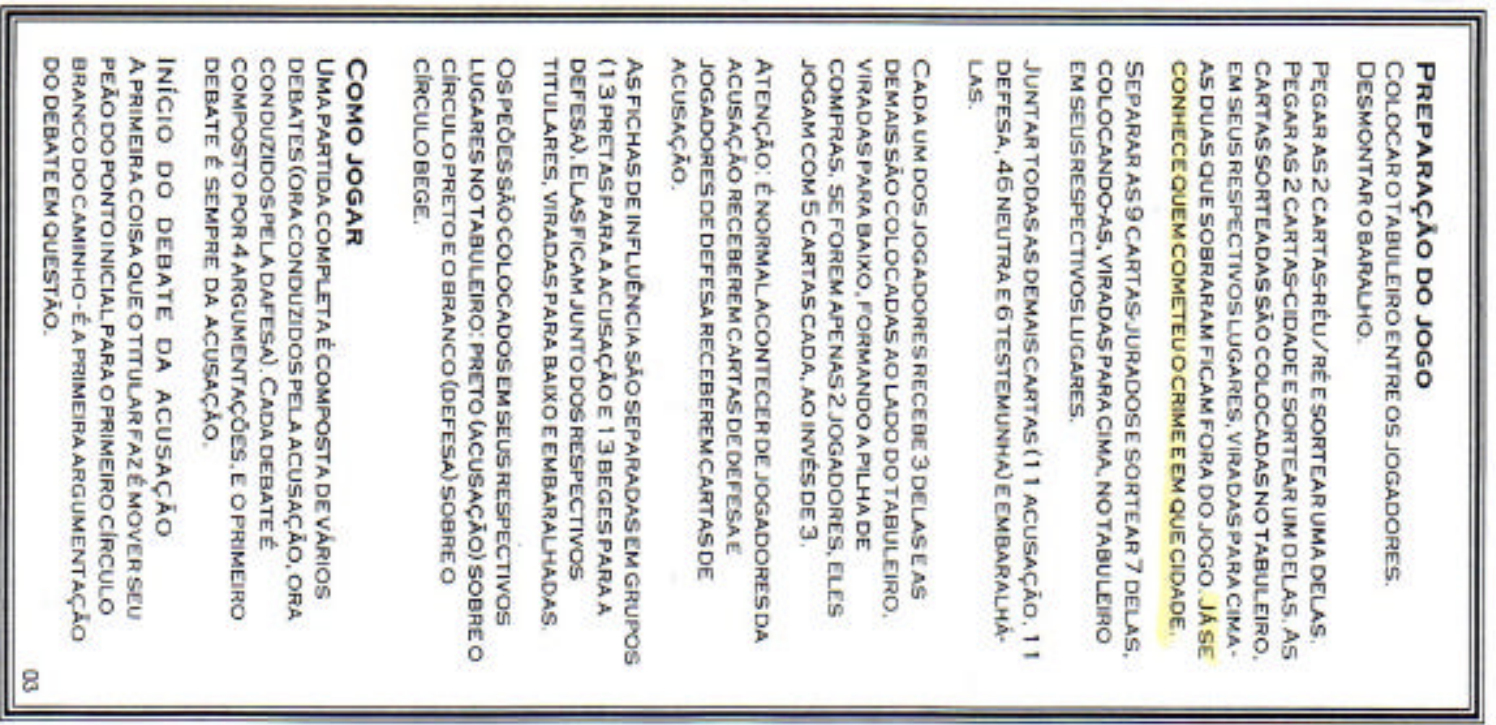



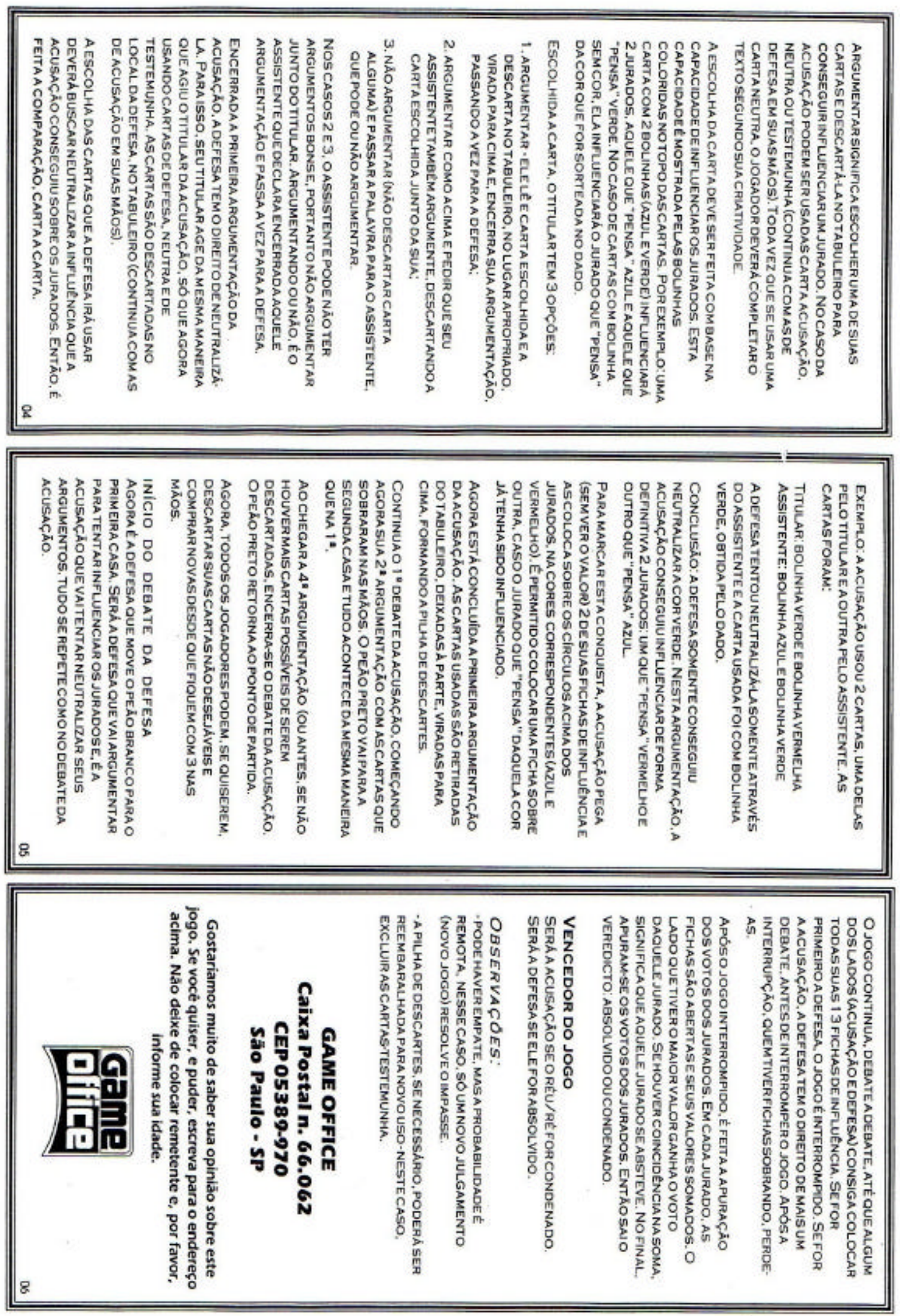


\section{- Regras}

Algumas comparações entre as regras do jogo Veredicto e as do Júri "real" permitem o detalhamento de certas questões e análises a respeito da lógica que estrutura o desenrolar das sessões de julgamento. Vale reafirmar que o primeiro, longe de falhar ao simular o segundo, interpreta-o e que, portanto, interpretaremos essa interpretação em busca de seus significados.

\begin{tabular}{|c|c|c|}
\hline & Veredicto & Júri "real"”2 \\
\hline $\begin{array}{l}\text { 1) instruções } \\
\text { preliminares }\end{array}$ & $\begin{array}{l}\text { o jogador deve "ler os textos da } \\
\text { tampa e do fundo da caixa para se } \\
\text { ambientar ao clima do jogo". }\end{array}$ & $\begin{array}{l}\text { os jogadores devem "ler" } \\
\text { (conhecer e dominar) a técnica } \\
\text { jurídica, a oratória, a dinâmica } \\
\text { do Júri e o perfil dos jurados. }\end{array}$ \\
\hline 2) objetivos & "absolver ou condenar o réu(ré)". & $\begin{array}{lcc}\text { debate sobre: } & \text { garantir } & \text { a } \\
\text { democracia X pô-la em risco. } & \end{array}$ \\
\hline 3) j( & $\begin{array}{l}\text { - } 2 \text { (acusador e defensor) ou } 4 \\
\text { (titular da acusação e seu } \\
\text { assistente, titular da defesa e } \\
\text { seu assistente) } \\
\text { - a partir de } 14 \text { anos. }\end{array}$ & $\begin{array}{l}\text { - promotor, defensor e jurados } \\
\text { (principais); } \\
\text { - juiz, réu, funcionários, PMs e } \\
\text { assistência (secundários). }\end{array}$ \\
\hline $\begin{array}{l}\text { 4) } \begin{array}{l}\text { con } \\
\text { do j }\end{array}\end{array}$ & $\begin{array}{llll}\text { um tabuleiro, } 87 & \text { cartas } & \mathrm{e} \\
\text { algumas peças. } & & & \end{array}$ & $\begin{array}{l}\text { espaços do plenário, jogadores } \\
\text { acima mencionados e as "peças" } \\
\text { processuais. }\end{array}$ \\
\hline $\begin{array}{l}\text { 5) preparação do } \\
\text { jogo }\end{array}$ & $\begin{array}{l}\text { - sorteio do sexo do réu, da } \\
\text { cidade do crime e dos } 7 \text { jurados. } \\
\text { - cartas-argumento e fichas de } \\
\text { influência são embaralhadas e } \\
\text { distribuídas. } \\
\text { - "peões-jogadores" são } \\
\text { posicionados no tabuleiro. }\end{array}$ & $\begin{array}{l}\text { - posicionamento inicial dos } \\
\text { participantes em plenário. } \\
\text { - sorteio dos jurados, pelo juiz, } \\
\text { com possibilidade de defensor e } \\
\text { promotor efetuarem recusas. } \\
\text { - posicionamento final dos } \\
\text { jurados sorteados. }\end{array}$ \\
\hline
\end{tabular}

$\overline{2}$ - No Anexo 2 estão reproduzidos os artigos do Código de Processo Penal Brasileiro (CPP) - 439 a 497 — referentes à "Organização do Júri". 


\begin{tabular}{|c|c|c|}
\hline & Veredicto & Júri "real" \\
\hline 6) $\mathrm{co}$ & $\begin{array}{l}\text { - o acusador elabora seu } 1^{\circ} \text { de } \\
4 \text { argumentos ou "passa". } \\
- \text { o defensor tenta neutralizar o } \\
1^{\circ} \text { argumento do acusador ou } \\
\text { elabora o seu } 1^{\circ} \text {. } \\
-\quad \text { marca-se qual dos dois } \\
\text { influenciou } 1 \text { ou mais jurados. } \\
- \text { o acusador elabora mais } 3 \\
\text { argumentos, intercalados pelas } \\
\text { tentativas de neutralização da } \\
\text { defesa e pela marcação das } \\
\text { influências. } \\
- \text { invertem-se as posições: a } \\
\text { defesa elabora } 4 \text { argumentos, } \\
\text { intercalados pelas tentativas da } \\
\text { acusação neutralizá-los e pela } \\
\text { marcação das influências. } \\
- \text { "O jogo continua (...) até que } \\
\text { algum dos lados (...) consiga colocar } \\
\text { todas suas } 13 \text { fichas de influência." } \\
\text { jupuração dos votos de cada } \\
\text { jerado e totalização dos mesmos. } \\
\text { Veredicto }\end{array}$ & $\begin{array}{l}\text { - jurados prestam compromisso } \\
\text { - interrogatório do réu. } \\
\text { - leitura do relatório pelo juiz. } \\
\text { - inquirição de testemunhas de } \\
\text { acusação e, depois, de defesa. } \\
\text { - sustentação oral do promotor } \\
\text { (até } 2 h) \text { e depois do defensor } \\
\text { (até } 2 h) \text {. } \\
\text { - possibilidade de réplica do } \\
\text { promotor ( } 1 / 2 \text { hora) e, depois, de } \\
\text { tréplica do defensor. } \\
\text { - possibilidade de os jurados } \\
\text { pedirem esclarecimentos. } \\
\text { - leitura e explicação, pelo juiz, } \\
\text { dos quesitos. } \\
\text { - retirada do juiz, promotor, } \\
\text { defensor e jurados para a sala } \\
\text { secreta. } \\
\text { - votação sigilosa dos quesitos, } \\
\text { pelos jurados, na sala secreta. } \\
\text { - apuração dos votos pelo juiz. } \\
\text { - cálculo da pena somente pelo } \\
\text { juiz. } \\
\text { - todos retornam ao plenário. } \\
\text { juiz. a sentença é proferida pelo }\end{array}$ \\
\hline $\begin{array}{l}\text { 7) vence } \\
\text { jogo }\end{array}$ & $\begin{array}{l}\text { "Será a acusação se o réu/ré for } \\
\text { condenado. Será a defesa se ele for } \\
\text { absolvido." }\end{array}$ & $\begin{array}{l}\text { seja o réu absolvido ou } \\
\text { condenado, é o ritual de exibição } \\
\text { da instituição social Júri e de } \\
\text { formas legítimas e ilegítimas de } \\
\text { matar que sempre "vencem". }\end{array}$ \\
\hline 8) o & $\begin{array}{l}\text { "Pode haver empate, (...), nesse } \\
\text { caso, só um novo julgamento, (novo } \\
\text { jogo) resolverá o impasse. }\end{array}$ & $\begin{array}{l}\text { não pode haver empate. Se a } \\
\text { sessão chegar ao fim, haverá } \\
\text { uma sentença ou absolutória ou } \\
\text { condenatória. }\end{array}$ \\
\hline
\end{tabular}

\section{1) instruções preliminares}

Nos dois "jogos", existe a idéia de que há um "clima" que envolve os jogadores e deve ser percebido, conhecido e dominado por eles.

No que diz respeito ao Júri, é opinião corrente, entre seus "mestres" — alguns juízes, promotores e defensores que fizeram carreira nessa instituição e publicaram textos a seu respeito - que um bom promotor e um bom advogado de Júri devem ter e aprimorar certas qualidades técnicas e pessoais. As técnicas - domínio dos procedimentos processuais específicos e de detalhes periciais dos crimes - , segundo 
esses "mestres", dependem de estudos aprofundados, enquanto as pessoais estabelecer empatia, falar com clareza e postura firme em plenário etc — dependem, em parte, de "dons" e, em parte, de aprendizado adquirido por "mimetismo" - assistir a muitos Júris até adaptar-se a sua dinâmica: “(...) clima de Júri é um estado de espírito que exige concentração técnica e emocional dos oradores." ${ }^{3}$. Também é consensual que “(...) ao se levantar para realizar seu trabalho profissional o orador deverá (...) sentir-se senhor do restrito auditório, conhecendo suas tendências, quer pessoais, quer coletivas."(Pimentel, 1988: 283).

\section{2) objetivos}

Uma leitura, mesmo que superficial, de vários textos doutrinário-jurídicos referentes aos objetivos ou à "razão de ser" do Tribunal do Júri no Brasil, revela que, mais do que absolver ou condenar réus, esse Tribunal representa um espaço de produção e exercício de valores sociais mais amplos.

Embora não seja objeto desta tese a análise de discursos sobre o Júri produzidos fora dos plenários —, uma vez que nos interessam os discursos produzidos no Júri, dentro dos plenários - tanto sobre a própria instituição quanto a respeito "da" sociedade - , quem quer que pontue os objetivos do Júri, extrapola o mero "absolver ou condenar o réu(ré)" e avança em debates de dimensão política.

Segundo alguns doutrinadores, o Tribunal do Júri, no Brasil, é "um direito ou garantia fundamental do indivíduo", tanto que se encontra previsto no título "Dos direitos e garantias fundamentais" da Constituição Federal ${ }^{4}$. Outros, por exemplo, afirmam que, “(...) principalmente no interior do país, o Júri perpetua a impunidade de criminosos que contam com a proteção de políticos de influência regional" (Acquaviva, 1991: 21 - nota de rodapé). O fato é que, quando se trata de discutir o Júri no Brasil, seja dentro e fora dos plenários, as opiniões, quase sempre, dividem-se entre seus defensores e detratores.

\footnotetext{
3 - Palestra proferida no curso O futuro do Júri no Brasil, promovido pelo Centro de Estudos e Aperfeiçoamento Funcional da Escola Superior do Ministério Público de São Paulo, pelo Dr. Octávio Borba de Vasconcelos Filho, em 31 de maio de 1999, das $9 \mathrm{~h}$ às $12 \mathrm{~h}$ e intitulada $A$ postura do Promotor de Justiça em plenário.

4 - "É reconhecida a instituição do júri, com a organização que Ihe der a lei, assegurados: a) a plenitude de defesa; b) o sigilo das votações; c) a soberania dos veredictos; d) a competência para o julgamento dos crimes dolosos contra a vida". (Constituição Federal, 1988, art. $5^{\circ}$, XXXVIII, d).
} 


\begin{tabular}{|c|c|}
\hline \multicolumn{2}{|c|}{ Principais argumentos relativos ao Tribunal do Júri no Brasil ${ }^{5}$} \\
\hline Favoráveis & Contrários \\
\hline $\begin{array}{l}\text { a) é um tribunal de conotação } \\
\text { democrática; }\end{array}$ & $\begin{array}{l}\text { a) em muitos países democráticos não há } \\
\text { mais Júri (França, Alemanha, Bélgica, } \\
\text { Itália, Grécia etc) e, mesmo nos Estados } \\
\text { Unidos, em várias situações, cabe ao réu } \\
\text { decidir se vai ou não a Júri. }\end{array}$ \\
\hline $\begin{array}{l}\text { b) jurados estão mais em contato com os } \\
\text { contextos em julgamento do que juízes } \\
\text { togados; }\end{array}$ & $\begin{array}{l}\text { b) juízes togados também são cidadãos e } \\
\text { participam da sociedade, além de terem } \\
\text { estudado para melhor compreendê-la; } \\
\text { jurados são susceptíveis a injunções; }\end{array}$ \\
\hline $\begin{array}{l}\text { c) se o jurado pode ser susceptível a } \\
\text { influências externas, o juiz togado pode } \\
\text { seguir ideologias e convicções próprias; }\end{array}$ & $\begin{array}{l}\text { c) juízes togados passam por longo período } \\
\text { de preparo profissional para que julguem } \\
\text { com imparcialidade; }\end{array}$ \\
\hline $\begin{array}{l}\text { d) Considerações não técnicas, mas } \\
\text { morais, éticas, psicológicas e e } \\
\text { econômicas orientam os jurados em } \\
\text { suas decisões, dosando eventuais } \\
\text { injustiças da aplicação "pura e fria" da } \\
\text { lei; }\end{array}$ & $\begin{array}{l}\text { d) nos debates do Júri prevalecem } \\
\text { argumentos emocionais e falsos que } \\
\text { iludem os jurados e os fazem perder de } \\
\text { vista a imparcialidade necessária a um } \\
\text { bom julgamento; }\end{array}$ \\
\hline $\begin{array}{l}\text { e) legisladores, assim como jurados, } \\
\text { podem ser leigos, pois o que importa é } \\
\text { o "bom senso". }\end{array}$ & $\begin{array}{l}\text { os geralmente não têm "bom senso } \\
\text { co", podendo desprezar provas } \\
\text { ttantes, por motivos emocionais; }\end{array}$ \\
\hline $\begin{array}{l}\text { f) o Júri contribui para a administração da } \\
\text { Justiça e garante o princípio da } \\
\text { publicidade dos atos ao exigir dos } \\
\text { profissionais um linguajar acessível aos } \\
\text { leigos; }\end{array}$ & $\begin{array}{l}\text { f) a complexidade dos crimes que vão à Júri } \\
\text { exige rigor técnico na exposição e } \\
\text { apreciação de provas; }\end{array}$ \\
\hline $\begin{array}{l}\text { g) o Júri tem um caráter educacional sobre } \\
\text { a população, pois as sessões são como } \\
\text { "(...) laboratórios onde se experimenta o } \\
\text { direito concreto e o próprio sentimento da } \\
\text { justiça (...)";, }\end{array}$ & $\begin{array}{l}\text { itos pelo Júri, por serem mais } \\
\text { e os que demais, aumentam a } \\
\text { ocial de impunidade e a de que } \\
\text { iciário não funciona; }\end{array}$ \\
\hline $\begin{array}{l}\text { h) pesquisas apontam que o Júri não } \\
\text { comete mais erros que tribunais não } \\
\text { populares; }\end{array}$ & $\begin{array}{l}\text { Ue o Júri comete mais } \\
\text { o populares; }\end{array}$ \\
\hline $\begin{array}{l}\text { i) o Júri atende, de modo eficaz, a vários } \\
\text { princípios processuais, como acusação, } \\
\text { audiência, contraditório, oralidade etc; }\end{array}$ & $\begin{array}{llcc}\text { i) soluções "extra-legais" de } & \text { muitos } \\
& \text { veredictos desprestigiam a Justiça; }\end{array}$ \\
\hline $\begin{array}{l}\text { j) presume-se que as decisões do Júri } \\
\text { coincidem com a opinião popular e por } \\
\text { ela podem ser melhor assimiladas. }\end{array}$ & $\begin{array}{l}\text { los não expressa a } \\
\text { interesses da classe } \\
\text { 1. }\end{array}$ \\
\hline
\end{tabular}

\footnotetext{
5 - Na elaboração deste quadro, argumentos recentes, provenientes de diversos textos, palestras e debates sobre o Júri brasileiro foram considerados e mesclados, de modo que as respectivas fontes serão citadas quando de menções mais específicas.

${ }^{6}$ - ALMEIDA, Dario Martins de - O livro do jurado. Coimbra: Livraria Almedina, 1977 (pg. 19).
} 
Como seria de se imaginar, são enfatizados, nos plenários, especialmente nos discursos que juízes, promotores e defensores dirigem aos jurados, argumentos favoráveis ao Júri. Nos corredores dos tribunais, todavia, esses mesmos profissionais, não raras vezes, reconhecem e discutem "problemas" da instituição, até concordando com alguns dos argumentos desfavoráveis a ela.

Muitos desses argumentos já propiciaram teses, livros, artigos, mesas redondas em congressos etc, razão pela qual retomálos, em todos os seus meandros, redundaria noutra tese ${ }^{7}$. Portanto, para o fim a que nos propomos - perceber significados subjacentes a esses debates - , cabem algumas reflexões de caráter mais amplo.

O que parece mais relevante entre os que consideram o Júri democrático e os que o consideram um risco para a democracia é, em primeiro lugar, identificar as diversas abordagens de democracia que estão "em jogo". Há juristas, por exemplo, que, mesmo sem dominarem e/ou denominarem o alcance do conceito de elitismo democrático (Dahl, 1989; Sartori, 1994; Schumpeter, 1971), dele estão tratando quando afirmam que jurados leigos não têm a devida expertise para julgar e que, portanto, compete a uma elite jurídica - autocrática, capaz e controladora - , conduzir racionalmente tal tarefa.

Os que defendem a validade e mesmo necessidade da participação de jurados leigos para "oxigenar" o Poder Judiciário, geralmente, desenvolvem, também nas entrelinhas, argumentos típicos do conceito de democracia participativa, pois afirmam que as pessoas, em geral, e os jurados, em particular, por sua notória idoneidade, são racionais e sabem o que querem, sendo possível participarem ativa e eficazmente do processo decisório (Macpherson, 1978; Martins, 1994).

No limite, a própria abordagem do sistema de Justiça, como detentor legal e legítimo do monopólio da coerção não violenta da criminalidade, respalda-se na tese de que as leis constituem condição sine qua non para a sobrevivência da sociedade civil, a qual é um dos pilares do conceito de democracia representativa ou do governo das leis (Bobbio, 1986).

E não faltam juristas que, ao conceberem o Júri como verdadeiro exercício de cidadania, exaltando seu caráter plural e pedagógico — - devido a nele profissionais relativizarem o jargão técnico e jurados experimentarem, "concretamente", o "sentimento de justiça" - aproximam -se do conceito de democracia emancipatória. São vários os defensores do Júri, no Brasil, que o apontam como um dos espaços políticos que, além

\footnotetext{
7 - Foi uma proposta semelhante a essa que deu origem a esta tese, conforme exponho no Capítulo 6.
} 
de ter resistido ao regime autoritário, persiste enquanto canal para a recuperação do "homem político virtuoso", participativo na esfera pública e capaz de perceber essa participação não como tendo um mero valor instrumental, mas como sendo valiosa, em si mesma (Arendt, 1989). Não exatamente com essas palavras, mas com esse sentido, vários profissionais fazem uma elegia do Júri, em plenário.

Enfim, se houvesse um "manual de regras" do Tribunal do Júri do qual constassem seus objetivos e como expô-los aos jurados, assim como existe o manual do jogo Veredicto, provavelmente, sua redação contemplaria esse debate que, muito superficialmente, acabamos de analisar e enfatizaria e enfatizaria o caráter democrático emancipatório do Júri ${ }^{8}$.

\section{3) número de jogadores}

É provável que, tal como anuncia o jogo Veredicto, a maioria das pessoas considere acusadores e defensores os principais — ou mesmo os únicos — responsáveis por tornar uma sessão "real" de Júri "um assunto tão envolvente". Contudo, isso seria simplificar uma dinâmica bem mais complexa e que, por isso mesmo, envolve o conjunto dos presentes à sessão. Todos não apenas se deixam envolver pelo julgamento, como nele estão envolvidos, direta ou indiretamente.

Conforme expusemos no capítulo anterior, embora a tensão máxima do jogo se concentre no embate entre promotor e defensor, uma vez que eles representam os dois "times" do Júri, restando, aparentemente, ao juiz, a função de guardião das regras, todos, inclusive jurados, funcionários, réus e assistentes contribuem, em diferentes medidas, para tal tensão.

O modo como funcionários se dirigem aos jurados, antes e depois do sorteio; a postura displicente ou compenetrada desses, ao longo da sessão; o fato de o réu permanecer ou não algemado ${ }^{9}$ e a maneira como ele olha as pessoas; a forma de o juiz conduzir os procedimentos iniciais, de acompanhar a seqüência da sessão e de, novamente, orientar os procedimentos finais; o tipo de assistência presente e suas reações, tudo isso e muito mais está em jogo, e compõe o jogo.

\footnotetext{
8 - No Anexo 3, está reproduzido um paper em que desenvolvi, mais detidamente, os conceitos de democracia mencionados, bem como a bibliografia a eles pertinente. Esse trabalho foi originalmente produzido para uma das disciplinas que cursei durante o doutorado.

9 - "A apresentação do réu algemado pode influenciar o convencimento do jurado menos preparado e mais emocionalmente influenciável", afirma Nucci, a partir da pesquisa que realizou com jurados do 3 Tribunal do Júri de São Paulo, apesar de apenas 7,52\% deles terem declarado que se influenciam por esse fato (Nucci, 1999: 158-159, 344).
} 
Restringir a análise da dinâmica do Júri ao aparente maniqueísmo que contrapõe acusação e defesa ou aos votos secretos de "sim" ou "não" dos jurados, seria desprezar o fato de que o jogo "real", seu ritual e teatralidade envolvem a todos os presentes e só ocorrem por causa desse envolvimento inevitável, seja explícito ou velado ${ }^{10}$.

10 - O pressuposto dessa complexidade da dinâmica das sessões de Júri é o que permite as análises desenvolvidas nos próximos capítulos. 


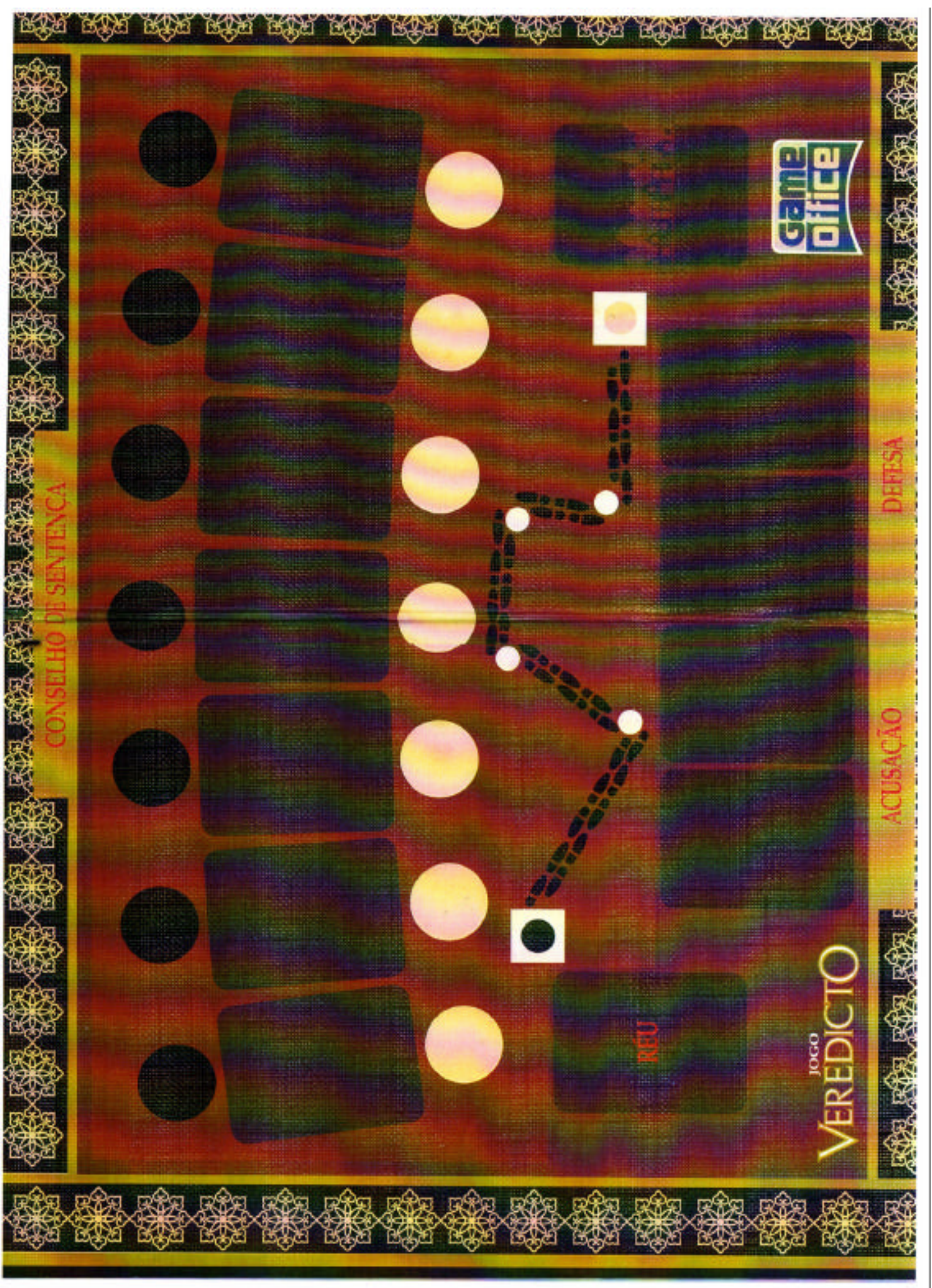


4) componentes do jogo: tabuleiro-plenário, cartas, peças e outras variáveis

$\mathrm{Na}$ apresentação dos componentes do jogo, esclarece-se que o tabuleiro "representa um tribunal". Ele é retangular $(43 \mathrm{~cm} \times 32,5 \mathrm{~cm})$, emoldurado por bordas pretas, cobertas por uma seqüência de pequenos arabescos brancos. O fundo é de um tom bordô-carmim, que lembra os grandes tapetes-galeria que se estendem, em solenidades, no caminho a ser pisado por autoridades.

Treze espaços retangulares, distribuídos por todo o tabuleiro, representam:

a) os 7 jurados — lado a lado, ocupando toda a parte superior;

b) o réu - à esquerda, abaixo do primeiro jurado;

c) a cidade em que aconteceu o crime — à direita, abaixo do último jurado;

d) o titular da acusação, seu assistente, o titular da defesa e seu assistente - os quatro, lado a lado, na parte inferior do tabuleiro.

Todos esses "espaços -personagens" são coloridos num tom lilás escuro.

Acima e abaixo de cada jurado há, respectivamente, um círculo negro e um bege claro. Os negros são destinados a ser preenchidos, ao longo do "jogo-julgamento", pelas "influências da acusação", e os bege claros pelas "influências da defesa".

Finalmente, no meio dos 13 retângulos, há um "caminho" - marcado por pegadas de sapatos e por 4 círculos brancos - que a defesa e a acusação percorrerão, a cada vez que debaterem e argumentarem.

São muitas as diferenças entre esse tabuleiro e os espaços físicos de um "plenário padrão" dos Tribunais do Júri de São Paulo, conforme já apresentamos no capítulo anterior, cabendo-nos perguntar se elas significam alguma coisa e o quê.

Uma das diferenças mais gritantes reside no fato de que, em nenhum plenário paulistano, os 7 jurados se sentam em uma só fileira, mas em duas, paralelas, de 3 e 4 lugares, sendo que os detrás costumam ficar num plano um pouco superior ao da frente, para que sua visibilidade não seja prejudicada. Essas fileiras ficam sempre numa das laterais da sala, às vezes num ângulo que mal permite à audiência observar os jurados e vice-versa.

Quanto ao espaço para assistentes, ausente no jogo Veredicto, nos plenários, conforme já apontamos, há espaço para, em média, de 40 a 50 pessoas sentadas, devidamente separadas dos manipuladores técnicos, jurados, réu e policiais por uma divisória baixa, com um pequeno portão no meio. Além disso, acusação e defesa não ficam lado a lado e o lugar do réu é próximo ao de seu defensor. 
A grande mesa do juiz, também ausente no tabuleiro do jogo Veredicto, é o lugar físico de maior destaque e visibilidade nos plenários paulistanos, situando-se em plano elevado, no centro da sala, de frente para a audiência.

Enfim, no tabuleiro do jogo Veredicto, o Tribunal está representado sem a presença de alguns "atores" - juiz, policiais, funcionários do tribunal - e sem espaços cênicos para eles, alterando, assim, algumas das posições restantes, especialmente as da defesa, da acusação e do réu. O que inferir disso ${ }^{11}$

Menos do que falhas, o que o tabuleiro do jogo Veredicto parece apresentar é uma espécie de zoom intencional de um plenário padrão. Como se fosse o resultado de um olhar focado e sintético, ele registra o que a provável maioria das pessoas mais nota numa sessão de Júri: jurados igualmente expostos às influências das argumentações do defensor e do acusador — por isso, estão lado a lado — e um réu presente, porém passivo - parado num dos extremos do caminho que os arguidores percorrem.

Tal "caminho" percorrido, tanto no jogo Veredicto quanto no Júri, é, de fato, uma seqüência de "passos", seja no sentido físico ou simbólico. Debatedores deslocam-se pelo plenário à medida que percorrem o processo, lendo peças, pontuando detalhes, levantando argumentos e contra-argumentos. Eles imprimem ritmo ao jogo.

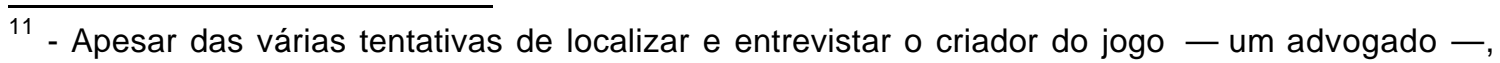
através de informações fornecidas por seu fabricante e seu distribuidor, infelizmente, não foi possível encontrá-lo.
} 


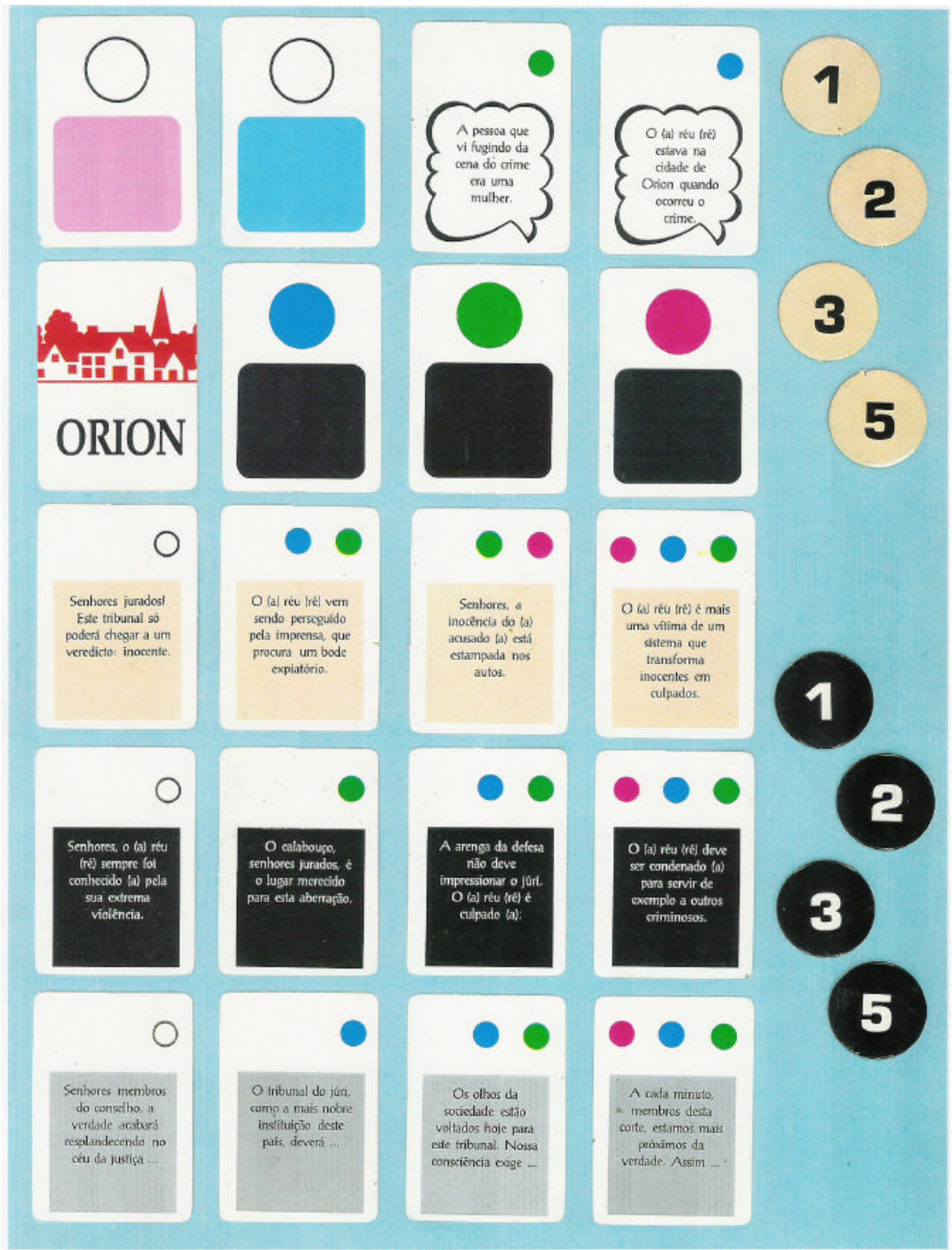


Em relação às cartas do jogo Veredicto, são três as variáveis nelas contempladas: o sexo do réu, a cidade em que ocorreu o crime e o modo de pensar dos jurados.

As duas primeiras interferem no jogo apenas de forma combinatória-aleatória, ou seja, se for sorteada uma ré e a acusação tiver, aleatoriamente, recebido uma cartatestemunha afirmando que uma mulher foi vista fugindo da cena do crime, o acusador poderá usar tal carta, satisfatoriamente. Se um réu for sorteado, essa mesma cartatestemunha, não será conveniente para o acusador, ocorrendo o mesmo em relação às cartas que nomeiam as duas cidades e em relação às quais testemunhas podem se manifestar. Não há, portanto, nenhuma outra influência possível dessas duas variáveis sobre o resultado do jogo, pois nele não se argumentará nada referente a relações de gênero - padrões de conduta ou estereótipos de réus e rés — ou à localização do crime - tipo de cidade, de bairro, de local onde viviam os envolvidos e/ou o crime ocorreu.

Réu e testemunhas não têm definidos seus sexos, idades, ocupações, estado civil, etnia, religião, local de moradia etc. Defensores e acusadores também não têm seus perfis "em jogo", sugerindo que as argumentações que construirão terão poder quase absoluto para legitimar ou não os homicídios, apenas com base nos conteúdos valorativos manipulados e de como o serão, independentemente de quem os manipulará.

Contudo, em relação aos jurados, é contemplada a variável "forma de pensar". Assim como no Júri "real", o jogo Veredicto pontua a importância determinante da relação entre argumentadores e o perfil de seus ouvintes: "O conhecimento daqueles que se pretende conquistar é, pois, uma condição prévia de qualquer argumentação eficaz" (Perelman \& Olbrechts-Tyteca, 1996).

Afirma, um famoso penalista, em artigo sobre a oratória perante o Júri: "Não pode o orador contentar-se com uma exibição técnica, (...). A tarefa é mais árdua.(...). Será recomendável, (...) que, desde o início da sessão periódica do Júri, procure conhecer o resultado do sorteio e a convocação dos jurados. Terá, assim, tempo suficiente para informar-se a respeito de cada um deles, (...) coletando as notícias mais completas a seu respeito, (...). O dálogo sempre terá mais probabilidade de sucesso se quem fala conhece o modo de ser e de pensar do interlocutor. (...). Tendo em vista a natureza da causa, elaborará a lista de suas recusas, serevindo-se das informações obtidas. (...), os nomes dos jurados, suas profissões e tendências, inclusive as posições sociais. Isto será muito útil, porque permitirá ao orador o estabelecimento de particular empatia, possibilitando individualizar, em dado momento, o diálogo direto e intencional com qualquer um deles."(Pimentel, 1988: 283 - grifo meu).

Portanto, a "forma de pensar" dos jurados, representada no jogo Veredicto por cores, através das quais acusador e defensor se orientam para influenciá-los, no Júri 
"real", é uma variável complexa, resultante do equacionamento de várias outras por parte dos acusadores e defensores a fim de chegarem a uma conclusão, conforme veremos a seguir.

Os jogadores do Veredicto podem ser dois ou quatro - um ou dois defensores e um ou dois acusadores - , e o desfecho do jogo é determinado pela habilidade com que utilizam as cartas que, ao acaso, recebem. Tal habilidade consta de selecionar boas frases, desenvolver outras incompletas, desprezar as que não convêm e, estrategicamente, direcioná-las aos jurados, conforme as "cores" de seus pensamentos. As falas das testemunhas, também dependendo da sorte e de um pouco de habilidade argumentativa, podem favorecer ou prejudicar o réu.

Voltando aos nomes dados às duas cidades em que, necessariamente, o jogo Veredicto apontará a ocorrência dos crimes — Orion e Polar —, eles são fictícios, mas, como "a vida imita a arte" (ou é o contrário?), assisti a uma sessão em que a ré morava no Jardim Orion, zona sul da Capital. Seu advogado referiu-se a tal bairro, em meio ao seguinte discurso: “(...) pesquisa da ONU revela que, no Brasil, 50 milhões de pessoas recebem $R \$ 80,00$ por mês e que, só no Estado de São Paulo, são 11 milhões nessa situação. (...). Grande parte dessas pessoas mora nos Jardins Orions da periferia, onde sobreviver é um ato de heroísmo." 12

Folheando o respectivo processo, descobri que esse advogado, na defesa prévia, registrara: "Segundo consta às fls (...), a Rua (...) não consta no Guia Mapograf, embora conste o Jd. Orion (345-C-21). Requer-se, pois, ofício à municipalidade, para identificação de tal logradouro e respectivo $n^{\circ}(. ..) .{ }^{, 13}$ Como inúmeras ruas surgem, diária e ilegalmente, em São Paulo, especialmente em áreas de preservação de mananciais, como é o caso do bairro em questão, é provável que a rua em que morava a ré não estivesse no referido "Guia”.

O Estado, no exercício de suas funções policial e judicial nem sempre encontra os lugares em que ele próprio descumpre suas obrigações sociais.

Outra "sutileza" desse processo do Jardim Orion, é que, em várias peças, como na denúncia do promotor, a residência da ré é tida como localizada "nas proximidades"do bar onde ocorreu o crime - Jardim Sousa. Todavia, entre esses endereços está toda a parte norte da represa Guarapiranga, mais o bairro do Socorro e parte da Cidade Dutra, ou seja, "a" periferia, "os Jardins Orions" aparecem tão opacos e vagos, na maioria dos discursos de operadores técnicos, quanto "a" África ou "a" América do Sul, na maioria dos discursos geopolíticos dos países centrais.

$\overline{12}$ - 19/07/2001, \pm 15 h30', Plenário 8 do $1^{\circ}$ Tribunal do Júri (Barra Funda). 
A famosa conclusão antropológica de que a cultura é como uma lente através da qual o homem vê o mundo (Benedict, 1972: 19-20) e de que, portanto, estamos todos condicionados a vê-lo a partir de referenciais herdados de nossas experiências mais próximas e profundas, encontra, no exemplo citado, apenas mais uma tradução. A maioria dos operadores do direito, especialmente juízes, promotores e advogados, vê a cidade de São Paulo a partir de um referencial de classe média, capaz de identificar sutis distinções entre bairros centrais, mas incapaz de conceber "a periferia" como algo mais que um grande e amorfo espaço de pobreza e criminalidade. ${ }^{14}$

Mas, como já dissemos, parágrafos atrás, nosso principal objetivo, com essas análises do jogo Veredicto, é interpretar o modo como nele o funcionamento do Júri "real" é interpretado. Portanto, os componentes do jogo Veredicto, especialmente as cartas que contêm um vocabulário pré-fixado para falas de testemunhas e arguidores, indicam algo que também ocorre nas sessões do Júri-“real”. Nos dois casos, há um vocabulário préfixado, inclusive com frases comuns a acusadores e defensores - "Senhores membros do conselho, a verdade acabará resplandecendo no céu da justiça" ou "O tribunal do júri, como a mais nobre instituição deste país, deverá..." ou ainda "Os olhos da sociedade estão voltados toje para este tribunal. Nossa consciência exige..." - , que só ganha vida e sentidos quando preenchido, em ato - durante a "partida" ou nos plenários - por um outro conjunto de palavras e expressões que, assim como Geertz, chamaremos de vocabulário de sentimento ${ }^{15}$ (Geertz, 1978: 317).

\section{5) preparação do jogo}

No jogo Veredicto, após o sorteio que determina se será julgado um réu ou uma ré, se o crime foi cometido em Orion ou Polar e quais, dentre os 9 jurados, serão os 7 a compor o Conselho de Sentença, são embaralhadas as 74 cartas, com frases para argumentações da defesa e da acusação, e cada jogador recebe 3 (se forem 4 jogadores) ou 5 (se forem 2). Faz parte do jogo que jogadores da acusação recebam cartas da defesa e vice-versa, o que implica que não poderão usá-las.

As 13 "fichas de influência" (círculos numerados), de cada jogador, ficam sob sua posse, mas sem que conheçam seus valores, e os 2 peões são colocados no centro do tabuleiro, nos locais indicados para a defesa e a acusação.

\footnotetext{
13 - Processo $n^{0} 1.564 / 95,1^{\text {a }}$ Vara do Tribunal do Júri da Capital, fl. 201.

14 - da mesma forma, a Cidade do México é percebida e concebida de múltiplas maneiras pelos que por ela transitam: "viajantes" que, a partir de suas "travessias e imaginários", concebem-na como sendo várias cidades e tendo distintos significados (Canclini et al, 1996).
} 
Mais uma vez, vale registrar que essa preparação do jogo Veredicto indica apenas critérios aleatórios de seleção de jurados, ao passo que, nos Júris "reais", os critérios utilizados costumam seguir lógicas intencionais de seleção, baseadas no que denominamos, no capítulo 4 (pg 113), de uma "sociologia selvagem".

A listagem anual de jurados, em cada Tribunal do Júri, decorre de uma mescla de critérios objetivos - ser brasileiro nato ou naturalizado, no gozo de seus direitos políticos, maior de 21 anos $^{16}$ - e subjetivos - ser cidadão capaz e de notória idoneidade moral.

Num dos mais consultados manuais de "teoria e prática" a respeito do Júri, os autores registram: "A idoneidade exigida significa aptidão, capacidade, tanto moral como intelectual. (...), o corpo de jurados se deve compor dos cidadãos mais notáveis do município por seus conhecimentos, experiência, retidão de conduta, independência e elevação de caráter. (...) a lei faculta ao juiz requisitar às autoridades locais, associações de clas se, sindicatos profissionais e repartições públicas a indicação de cidadãos que reunam as condições legais para exercer a função de jurado." (Marrey et al, 1997: 206)

Especificamente num artigo sobre a "notória idoneidade", um promotor escreveu: "Hoje, lamentavelmente, em um momento que os referenciais da "notória idoneidade" se perdem no caleidoscópio confuso dos crimes de white-collar (...) depara-se, muitas vezes, o Juiz de Direito - e o Ministério Público, na atividade fiscalizadora - na indefinição concreta do que seja a "notória idoneidade".(...) uma boa composição da lista anual será a convocação de cidadãos que evidenciem, por seus afazeres e modus vivendi, qualidades (...). O sensor intelectivo, a boa-fé salvaguardada pela independência moral, não sucumbirá ao medo e às ameaças (...) buscando com abnegação, a verdade, ao julgar. Sobretudo é preciso que o jurado tenha disposição de ser jurado, (...). Leigos, sim, mas que não sejam apequenados na inteligência, encolhidos de raciocínio e, tampouco, devedores morais.". (Bonfim, 1993: 309-316).

Dentre os listados, anualmente, são convocados 21 jurados, a cada sessão, dos quais ao menos 15 devem estar presentes para que o juiz sorteie os 7 que comporão o Conselho de Sentença. À medida que as cédulas com os nomes dos presentes são, ao acaso, sorteadas pelo juiz, que os lê, em voz alta, tanto a defesa — primeiro - quanto a

\footnotetext{
15 - tema desenvolvido no Capítulo 5.

16 - não podem servir como jurados o menor, mesmo que emancipado ou já casado, o analfabeto e, mesmo não havendo lei explícita, o surdo que não usar aparelho, o mudo e o cego. Há isenções em função do exercício de determinados cargos, da sujeição a certas disciplinas ou a votos de obediência (art. 436 do CPP). Os maiores de 60 também podem se isentar, caso queiram (Marrey et al, 1997: 106). Quanto ao sexo, a legislação imperial somente aceitava para o serviço do Júri "homens bons, honrados, inteligentes e patriotas" (Dec. De 18.6.1822). Até o advento do Dec. 21.076, de 24.2.32, as mulheres não exerciam o direito de voto; logo, não eram "cidadãs" e, por conseguinte, não podiam ser juradas.
} 
acusação — depois —, podem recusar até 3 jurados, sem explicitar os motivos (art. $459 \S$ $2^{\circ}$ - CPP).

Na prática, o que fundamenta essas "recusas peremptórias" é uma análise psicosociológica fulminante que promotor e defensor fazem dos jurados. Dispondo de uma lista com os nomes e profissões dos 21 convocados, seguidos das assinaturas dos presentes, promotor e defensor exercitam seu "olhar clínico" sobre os sorteados para cruzarem, mentalmente, as variáveis profissão, gênero, etnia, faixa etária, aparência - modo de vestir, de sentar, de olhar - e, às vezes, até o fato do jurado ser novato ou não. Em segundos, o resultado desse cruzamento é ponderado em função de características do caso em julgamento, combinadas com perfis do réu e da vítima e, depois de mais alguns segundos, defensor e promotor declaram, em voz alta, se aceitam ou não cada sorteado.

Numa das sessões que acompanhei, sentada ao lado do promotor, ele esgotou suas recusas, depois de não aceitar uma publicitária, uma pajem e um comerciante. Ao pé do meu ouvido, justificou-se: "Como preciso de um Conselho de Sentença que mantenha a condenação ${ }^{17}$, ainda que amenizando-a, preciso de jurados mais conservadores. Esse, provavelmente, não é o perfil de uma publicitária, de uma pajem e do comerciante que está aí. Publicitários são formadores de opinião, gostam de questionar, criticar. A pajem lida com um universo muito distante do que será julgado e esse comerciante tem aparência de insatisfeito".

Ainda sobre a seleção de jurados, comentou: "As mulheres são menos influenciáveis por argumentos de dor física e são mais sensíveis a argumentos que se referem a dores morais". Recomendou-me a leitura de um livro que trata da seleção de jurados nos Estados Unidos (Hastie et al, 1986) e mostrou-me quais eram os outros livros que gostava de ter, sempre à mão, no plenário. ${ }^{18}$ Os jurados sorteados - escolhidos e recusados -, nessa sessão, foram:

\footnotetext{
17 - tratava-se do $3^{0}$ julgamento do réu, pelo mesmo crime, pois os dois anteriores foram anulados; $15 / 08 / 2001$, das $12 \mathrm{~h}$ às $16 \mathrm{~h} 45^{\prime}$, Plenário 7 do $1^{\circ}$ Tribunal do Júri (Barra Funda).

${ }_{18}$ 1) GUERRA, J. B. Cordeiro - A arte de acusar. Rio de Janeiro; Forense Universitária, 1988; 2) PEREIRA, José Ruy Borges - O plenário do Júri. Saraiva; 3) ALTAVILLA, Enrico - Psicologia Judiciária (vol. I - O processo psicológico e a verdade judicial; vol. II - Personagens do Processo Penal). $O 2^{\circ}$ e o $3^{\circ}$ são clássicos técnico-doutrinários. $O 1^{\circ}$ é uma espécie de manual de sugestões a jovens advogados e promotores sobre o que fazer em plenário, o que lembrar, como se conduzir etc.
} 


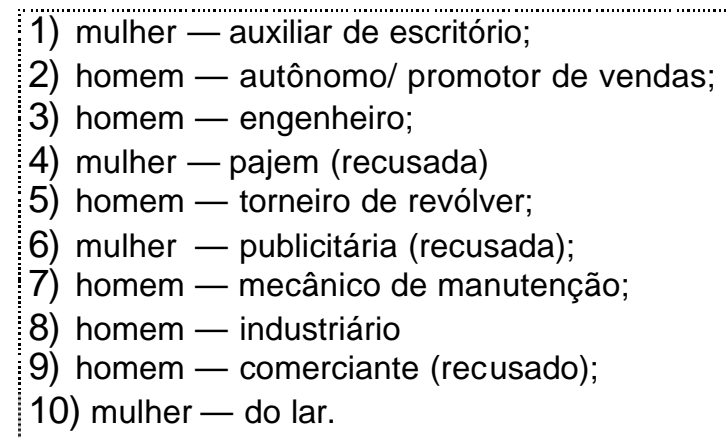

Em relação ao jurado $\mathrm{n}^{\circ} 8$, assim que ele foi sorteado e aceito pelo defensor e pelo promotor, esse comentou comigo: "Note que é o único que está de terno; o que não é uma exigência. Provavelmente, ele respeita as instituições. Portanto, é um jurado ideal para manter as decisões anteriores dos dois outros júris que já condenaram esse réu."

$\mathrm{Na}$ já mencionada pesquisa, realizada no $3^{\circ}$ Tribunal do Júri de São Paulo, $68,81 \%$ dos jurados entrevistados declararam que não se sentiriam constrangidos se fossem recusados pela acusação ou pela defesa, sem saberem a razão (Nucci, 1999: 148-151 e 358). Certa vez, um jurado recusado comentou comigo, ao sair: "É frustrante, mas também é um alívio. Afinal a gente veio até aqui e tudo o mais... Mas sabe-se lá quanto tempo a coisa iria demorar. Vou prá casa, descansar." Enfim, as reações devem mesclar vários sentimentos para além do constrangimento ou da ausência desse, mas, para se chegar a alguma conclusão a esse respeito, seria necessário uma investigação qualitativa junto aos recusados.

Quanto à possibilidade de três recusas imotivadas, tanto para defesa quanto para a acusação, é majoritária, dentre os profissionais brasileiros do Júri, a opinião de que, com isso, nosso sistema assegura a plenitude da defesa, bem como o aperfeiçoamento e o prestígio da própria instituição: “(...) o direito da recusação é complemento da instituição do Júri, seu acessório indispensável, seu princípio de vida.(...). Pode haver ódios, antipatias, ou fundadas ou nascidas somente de prevenções, preconceitos que não se podem explicar ou menos provar, e que, entretanto, exerçam influência e impressões incômodas e aflitivas sobre o espírito do acusado ou acusador. (...), tirante o folclore e o misticismo (...), cuja estigmatização (...) pretenda 'catalogar' jurados convenientes ou não, a 'recusa', quando corretamente exercida, ajuda ao aperfeiçoamento do Júri." (Bonfim, 1993: 314-315)

Segundo Hastie (1986), em países como Estados Unidos e Inglaterra, o processo de escolha dos jurados faz parte integrante e decisiva do processo de julgamento, tanto que há firmas de consultoria que disponibilizam equipes de profissionais especializados em selecioná-los. Esses são "consultores" ou "peritos" em Júri - psicanalistas, 
sociólogos, grafólogos, professores de direito — que estudam o "genótipo" e o "fenótipo" dos jurados - histórico familiar e profissional, hábitos cotidianos e esporádicos, atuais e passados etc - para, antecipando-se a suas prováveis tendências de voto, orientarem promotores e defensores a recusá-los ou aceitá-los ${ }^{19}$ : "Os consultores estudavam os jurados porque, primeiro, para isso eram regiamente pagos e, segundo, porque afirmavam ser capazes de analisar profundamente uma pessoa através de sua linguagem corporal (...) A defesa tinha nada menos de seis especialistas em júri examinando tiques faciais e pontadas de hemorróidas. $A$ acusação estava usando apenas quatro." (Grisham, 1998: 32-33).

No Brasil, embora não existam tais firmas e equipes de selecionadores de jurados, sua escolha, geralmente, não é aleatória, bem como a definição dos operadores técnicos que atuam em certos julgamentos. Algumas vezes, em função da "fama" do réu e/ou da vítima, a mídia passa a dar especial cobertura a determinados casos, influenciando os jurados e acionando vaidades profissionais de juízes, promotores, defensores, funcionários e mesmo de PMs encarregados da segurança das sessões. ${ }^{20}$

Alguns juristas brasileiros sugerem uma ampliação do conhecimento prévio que promotor e defensor poderiam ter dos jurados: "As partes, antes da instalação da sessão, deveriam ter a oportunidade de fazer algumas perguntas aos jurados presentes e ainda não sorteados, buscando extrair seus preconceitos e modos particulares de pensar e agir, a fim de que, a título de exemplo, um comerciante que já foi assaltado várias vezes não tome parte no Conselho de Sentença para julgar um réu acusado de homicídio seguido de roubo. Ou que uma pessoa, extremamente religiosa, entendendo que somente quem julga é Deus, não seja levada a deliberar acerca de um perigoso marginal." (Nucci, 1999: 150).

Seja de que forma for, sortear aleatoriamente 7 dentre 9 jurados — jogo Veredicto - é muito diferente de, através de critérios sócio-econômico-morais, listar centenas para cada Tribunal, convocar 21 para cada sessão, dos quais pelo menos 15 devem comparecer para que 7 componham o Conselho, havendo ou não recusas. Mas não nos enganemos, com a aparente simplicidade do jogo Veredicto, pois, somente enquanto ele

\footnotetext{
19 - Nos Estados Unidos, o número de "impugnações peremptórias" ou "eliminações", bem como o número de jurados convocados pode variar, dependendo do caso (Grisham, 1998: 55-56).

20 - Ao contrário do que eu supunha, algumas "sessões de grande repercussão" - às quais só tive acesso porque, com muita antecedência, peguei senhas (julgamentos do "Maníaco do Parque", por exemplo) - não me surpreenderam, etnograficamente. Nelas, apenas notei alguns aspectos das "sessões normais" exacerbados: o tom grave e solene do juiz; comportamentos e discursos pomposos de promotor e defensor; olhares de expectativa e expressões de concordância, discordância e até de cansaço dos jurados; a posição de "guardiões do templo" dos PMs. Mas, a dinâmica do ritual estava tão presente nesses quanto nos julgamentos dos Zés e Manés desconhecidos que mataram outros Zés e Manés também desconhecidos. Por isso e por não se tratar, neste trabalho, de detalhar as polêmicas relações entre Júri e mídia (Bastos In Tucci, 1999:112-116), descartei a estratégia metodológica de privilegiar "julgamentos especiais".
} 
está nos preparativos, os jurados cumprem uma função "de tabuleiro". Uma vez iniciado, juntamente com acusador e defensor, os jurados vão para o centro do jogo, de sua lógica e de seu desfecho, exatamente como ocorre no Júri "real".

Finalizando e articulando as colocações anteriores, cabe um último comentário sobre as regras para preparação do jogo Veredicto. Nelas está registrado, ao final do $1^{\circ} \S$ : "Já se conhece quem cometeu o crime e em que cidade" (pg. 03)

Uma pergunta pertinente é: se o jogo simula um julgamento, cujo objetivo é absolver ou condenar o réu, como, antes do Veredicto, já se conhece quem cometeu o crime e em que cidade? Se compreendida ao pé da letra, essa frase indica a tendência ilegal, embora bastante difundida no Brasil, de se considerar "todo réu culpado, até prova em contrário"21.

Essa aparente contradição, talvez, longe de ser um equívoco, seja a chave para se entender o jogo Veredicto e uma das principais características dos julgamentos pelo Júri. Num e noutros é irrelevante a descoberta de se o acusado matou ou não a vítima, pois o que importa é por que ele é acusado de tê-la matado.

Toda a argumentação com a qual se "brinca" no jogo Veredicto e nos Tribunais do Júri busca responder a esse por quê e, dependendo da resposta, o acusado tanto poderá ser absolvido, mesmo tendo cometido o assassinato, quanto condenado, embora inocente, pois o que se elabora, a cada partida de Veredicto e a cada sessão de Júri, são motivações para legitimar socialmente ou não a prática de homicídios. Esta afirmação é a base em que se desenvolverão os próximos capítulos, pois entendemos que ela abre portas para a compreensão do Júri enquanto um material socialúnico.

\section{6) Como jogar}

Justamente, uma das diferenças entre a dinâmica do jogo Veredicto e a do Júri é que, no segundo, a sessão tem início com a presença marcante do juiz presidente, pois é ele quem, além de conduzir a formação do Conselho de Sentença, interroga o réu. Em seguida, faz o relatório da ação penal, expondo "o fato", as provas e as conclusões das

\footnotetext{
21 - Uma discussão técnica, nesse mesmo sentido, é a do peso da sentença de pronú ncia quando do julgamento em plenário, pois, quando o réu vai a Júri, o juiz singular já proferiu uma sentença na qual motiva seu convencimento de que houve crime e indícios de que o réu foi o autor (art. 408 - CPP). "A doutrina e a jurisprudência são praticamente unânimes ao afirmar que uma sentença proferida em termos contundentes e com apreciações aprofundadas sobre o mérito da causa pode influenciar indevidamente o Conselho de Sentença, sendo causa de nulidade da decisão. (...). Por outro lado, continuará sendo exigível, por força da Constituição, que o juiz fundamente suas decisões.." (Nucci, 1999: 91 -93).
} 
partes (art. 466, caput - CPP). Se houver testemunhas, o juiz as inquirirá - primeiro as arroladas pelo promotor e depois as pela defesa. As testemunhas de acusação, além de inquiridas pelo juiz, podem responder a perguntas do promotor, de seu assistente, do defensor e dos jurados, nessa ordem. As testemunhas de defesa também podem responder a perguntas do defensor, do promotor, de seu assistente e dos jurados.

Enfim, somente após todos esses procedimentos, conduzidos pelo juiz, ele dá a palavra ao promotor, para que leia o "libelo"² e desenvolva a acusação em até, no máximo, duas horas. Durante essas, o defensor pode, eventualmente, pedir apartes que não serão somados às duas horas do promotor. O mesmo vale para quando for a vez do defensor que, por outras duas horas, sustentará oralmente a defesa do réu.

Embora tenha de seguir esse script do Código de Processo Penal, cada juiz o faz de maneira peculiar, de acordo com seu "estilo". Assisti, por exemplo, a sessões em que juízes e juízas adotaram um "estilo didático" e explicaram aos jurados o "sentido" de cada procedimento em plenário, afirmando, assim, seu saber-poder soberano. Assisti, também, a sessões em que os magistrados ou magistradas foram monossilábicos e mantiveram um ar blasé, a maior parte do tempo - o que pode ser uma outra maneira de afirmar um saber-poder soberano.

O jogo Veredicto não contempla a participação do juiz nem a do réu. Tampouco há versões a serem previamente relatadas, pois elas só se constituem à medida que acusador e defensor desenvolvem suas falas. Isto pontua o caráter criativo das argumentações, seja no sentido de que elas criam a história do crime e da inocência ou culpa do réu, seja no sentido de que sua força persuasiva depende da habilidade e sorte dos jogadores, ao jogarem.

Veredicto começa com o promotor cumprindo a seguinte regra: "Argumentar significa escolher uma de suas cartas e descartá-la no tabuleiro para conseguir influenciar um jurado". Por 4 vezes - 4 séries de debates — o promotor lançará uma "carta-argumento" e a defesa tentará, de imediato, neutralizá-lo, com outra "carta-argumento". Por exemplo: a acusação usa uma carta que, além de alguns dizeres, tem cores verde e azul — ou seja, pode influenciar jurados que "pensam verde e azul". A defesa "contra-ataca" com uma carta

\footnotetext{
22 - libelo é uma peça processual, assinada pelo promotor e por ele produzida logo depois de passada em julgado a sentença de pronúncia, na qual, por sua vez, o juiz especifica todas as circunstâncias qualificativas do crime. O libelo deve conter o nome do réu; a exposição do fato criminoso (em artigos); a indicação das circunstâncias agravantes, expressamente definidas na lei penal, e de todos os fatos e circunstâncias que devem influir na fixação da pena, além de indicação da medida de segurança aplicável. Podem acompanhá-lo o rol de testemunhas a depor em plenário (até 5), bem como documentos e requisição de diligências (arts. 416 e 417 - CPP).
} 
que, além de outros dizeres, tem somente a cor verde. Resultado: o "jurado verde" foi neutralizado pela defesa e o "azul" foi influenciado pela acusação. Para marcar essa conquista, o jogador-acusador deposita uma "ficha de influência" — sua vara addat, diria Huizinga (1980: 89) — junto ao jurado azul, sem ver o valor da ficha. Isto se repete por mais 3 vezes e, depois, invertem-se as posições.

A defesa, também por 4 vezes, lançará argumentos que o promotor tentará neutralizar. Essas argumentações continuam, alternadamente, até terminarem as "fichas de influência" de um deles, ou seja, não há um limite pré-definido de argumentações. 0 limite depende do esgotamento das possibilidades de cada jogador.

No Júri "real", as partes não se interrompem, oralmente, a cada argumento, pois as "regras" prevêem que devem se "neutralizar" em, no máximo, dois blocos, ou seja, somente depois do $1^{\circ}$ conjunto de argumentações da acusação, a defesa pode desenvolver seu $1^{\circ}$ conjunto de contra-argumentações. No total, são 5 as horas previstas para esses "debates": duas para o promotor, duas para a defesa ( $\left.1^{\circ} \mathrm{bloco}\right)$, meia hora para a réplica do promotor e mais meia hora para a tréplica da defesa $\left(2^{\circ}\right)$, caso queiram.

No jogo Veredicto, as interrupções fazem parte das regras que levam a uma dinâmica, aparentemente, mais dialógica que a do Júri "real". Aparentemente porque, de acordo com as declarações de um promotor aposentado, "há muito mais apartes no Júri do que os que os ouvidos registram, pois os gestos e caretas do defensor, enquanto o promotor fala e vice-versa, são tipos de apartes, (...)" 23 .

Influenciar jurados, segundo as regras de Veredicto, é levar em conta "a cor de seu modo de pensar" - azul, verde ou rosa —, e atingi-los, da melhor maneira possível, com as cores das cartas de argumentação que se têm em mãos. Uma carta de argumentação pode ter as 3 cores e, portanto, influenciar, simultaneamente, 3 jurados, ou pode ter duas ou uma só e influenciar dois ou apenas um jurado, respectivamente.

No Júri "real", embora tais cartas de influência materialmente não existam, promotores e defensores, de certo modo, imaginam "a cor do pensamento dos jurados" ao lançarem seus argumentos para influenciá-los, afinal "Para que uma argumentação se desenvolva, é preciso, de fato, que aqueles a quem ela se destina lhe prestem alguma atenção (...), como a argumentação visa obter a adesão daqueles a quem se dirige, ela é, por inteiro,

\footnotetext{
23 - Palestra proferida no curso O futuro do Júri no Brasil, promovido pelo Centro de Estudos e Aperfeiçoamento Funcional da Escola Superior do Ministério Público de São Paulo, pelo Dr. Hermínio Alberto Marques Porto, em 10 de maio de 1999, das 9h às 10h30' e intitulada A evolução histórica do Júri.
} 
relativa ao auditório que pretende influenciar. "(Perelman e Olbrechts-Tyteca, 1996: 20-21). É preciso, portanto, acertar as "cores" dos pensamentos.

Disse-me um promotor: "Essa história de alguns jurados, enquanto a gente fala, ficarem balançando a cabeça, como se estivessem concordando e aceitando nossos argumentos, é 'pegatrouxa', pois a maioria faz isso tanto para o promotor quanto para o defensor. É só um modo de acompanhar. Eles levam muito a sério o fato de não poderem expressar o que estão sentindo, embora, às vezes, deixem escapar alguns sinais de agrado ou desagrado. Mas é a gente quem tem de imaginar o que eles pensam e se antecipar, (...). Certas frases, eu falo olhando para as juradas e outras para os jurados. Não é à toa que eu, quando digo certas coisas, fico ao lado de uma dona de casa e, depois, vou para o lado do jovem empresário que quer subir na vida (...). Mas a gente se engana, porque os jurados jogam com essa história da incomunicabilidade e do sigilo dos votos. Esse é o poder deles. ${ }^{24}$

Esse depoimento não só revela a intensa leitura de sinais não verbais que percorre a sessão, durante todo o seu transcorrer, como indica uma percepção apurada da microfísica do poder (Foucault, 1984) existente no Júri. Longe de ser uma arena de luta em que, de um lado, há dominadores e, de outro, dominados, esse promotor dá-se conta da sutil e até perversa teia de recíprocas dominações "em jogo", especialmente ao captar que jurados, utilizam a seu favor, o que, aparentemente, poderia limitar-lhes: "(...)os jurados jogam com essa história da incomunicabilidade e do sigilo dos votos. Esse é o poder deles."

Vale ainda registrar que o fato de, no jogo Veredicto, a acusação receber cartas que seriam úteis à defesa e vice-versa, implica que os dois "lados" ocupam posições conjunturais, pois, se quisessem e pudessem, teriam condições de trocá-las. Do mesmo modo, nos julgamentos "reais" é comum a defesa conhecer detalhes que omite para não prejudicar o réu, o mesmo fazendo a acusação, ao silenciar ou não explorar detalhes que o favoreceriam. Sem contar que as carreiras de muitos promotores públicos, advogados de defesa e juízes, não raramente, intercambiam-se, numa dada altura de suas vidas, havendo promotores que passam a advogar, assim como advogados que vão para a magistratura ou para o Ministério Público. (Vianna et al, 1997: 187-203). Portanto, "os jogadores" ocupam posições que, elas, sim, são estruturais enquanto imprescindíveis ao funcionamento do jogo, mas conjunturais em relação a quem as ocupa. Nisso, “(...) reside $o$

\footnotetext{
$\overline{24}$ - 15/08/2001, das 12h às 16 h45', Plenário 7 do $1^{\circ}$ Tribunal do Júri (Barra Funda).
} 
segredo", declarou-me um advogado: "Preparar uma boa defesa é dominar tanto os argumentos que o promotor poderá usar contra o réu, quanto os que você pretende usar a seu favor (...)". ${ }^{25}$

\section{7) Vencedor do jogo}

O jogo Veredicto prossegue até que ou a defesa ou a acusação consigam distribuir todas as suas 13 fichas de influência sobre os jurados. Se a defesa terminar a distribuição primeiro, o jogo é interrompido, caso contrário, a defesa ainda terá direito a mais um debate. Uma vez interrompido, são apurados os "votos dos jurados", ou seja, as fichas de influência têm seus valores revelados e somados. Se, por exemplo, sobre o $1^{\circ}$ jurado, o valor das fichas de influência da defesa - beges - superar o valor das fichas de influência da acusação — negras —, o voto desse jurado é pela absolvição do réu(ré). Se houver empate, considera-se que o jurado se absteve. O resultado do jogo é revelado pela contagem de quantos jurados votaram pela absolvição e quantos pela condenação. Caso tenha havido abstenções e haja empate na contagem final, deverá haver novo jogo.

As regras do Veredicto encerram-se informando que "o vencedor do jogo será a acusação se o réu/ré for condenado. Será a defesa se ele for absolvido". No Júri, embora defensores, mais que promotores, expressem ar de vitória ou de fracasso diante da absolvição ou condenação de seus clientes, é "pelos corredores" que mais se conhece suas famas de "bons" ou "maus" profissionais, pois essas retratam sucesso ou fracasso e não resultam de uma matemática simples. Bom promotor não é mero sinônimo de ter conseguido muitas condenações e bom advogado de ter absolvido muitos réus. Um promotor com fama de "condenador voraz", de quem "nunca faz acordo" e que "destrói o réu" pode ser considerado desumano, levando as sessões em que atua e até o próprio Tribunal a receberem apelidos como "câmara de gás" ou "corredor da morte". Do mesmo modo, um defensor que acumula absolvições, especialmente de réus tidos como "altamente perigosos", pode ser taxado de inescrupuloso e carreirista. Enfim, no "jogo real" do Júri, resultados não podem ser medidos por quantidades, mas por qualidades e, estas, quase nunca, mostram-se à luz do dia, para qualquer um vê-las.

\footnotetext{
25 - entrevista telefônica, concedida em 13/07/2001 por um advogado que atuou numa das sessões a que eu assisti.
} 


\section{8) Observações}

Abstenções e empate, no "Júri real", são impossíveis, pois os 7 jurados sempre votam "sim" ou "não" para cada quesito. Do mesmo modo que não se admite que acusador e defensor deixem transparecer dúvidas em suas sustentações orais, pois isso é entendido como despreparo técnico e desqualificação ética e profissional. Também não se admite que jurados tenham dúvidas que os impeçam de decidir. Declarou-me um juiz: "Se eles pudessem se abster, nunca chegaríamos às sentenças, pois nem sempre é fácil decidir. Para um juiz também é assim e todos têm de chegar a um veredicto “26

Não há, portanto, no espaço excepcional e temporário do Júri, lugar para a expressão de dúvidas na hora de julgar. Elas, certamente, existem, mas a circunscrição do Júri num espaço e num tempo artificiais, como ocorre com qualquer jogo ou ritual, faz com que, uma hora, a "partida" e o encanto tenham de se dissolver.

Apesar de todas as diferenças apontadas entre o jogo Veredicto e o Júri "real", talvez sejam as mesmas as palavras-chave que melhor resumam suas estratégias: debates e argumentações. Nos dois casos, os esforços qualitativos para se lidar com idéias e palavras capazes de persuadir "formas de pensar", desembocam num desfecho aparentemente quantitativo: contagem de votos. Em outras palavras, o qualitativo debates e argumentações - acaba passando por mensuração e controle quantitativos e revelando uma lógica finalista-mecanicista. No jogo Veredicto, ela se expressa através das cores que se neutralizam e dos números que se agregam a cada jurado. Nos Júris "reais", o fim de uma sessão depende da contagem dos votos de sim ou não que os jurados dão, na sala secreta, para cada quesito formulado pelo juiz.

Talvez, como declarou o juiz mencionado, não fosse assim, nenhum dos dois "jogos" terminaria e serviria para o que servem: exprimir, através de casos particulares, passíveis de serem narrados e julgados em algumas horas, valores sociais conflituosos, complexos, multifacetados, de difícil "narração" e julgamento.

\footnotetext{
$\overline{26}$ - entrevista concedida em 22/02/1999, $1^{\circ}$ Tribunal do Júri (Vila Mariana).
} 


\section{Sol}

Complementando o $1^{\circ}$ capitulo, neste enfatizamos ainda mais o caráter lúdicoagonístico das sessões de Júri ou, em outras palavras, sua natureza essencialmente simbólica e, portanto, o quão propício é abordá-lo a partir de recursos analíticoantropológicos. Esses nos permitem perguntar - e tentar responder - o que está em jogo no Júri e o que esse domínio privilegiado ou área crítica manifesta e permite vislumbrar a respeito de alguns desejos e valores de nossa formação social.

Prosseguiremos com perguntas e tentativas de respostas, abordando, no próximo capítulo, o júri enquanto um ritual.

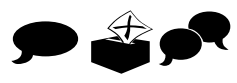




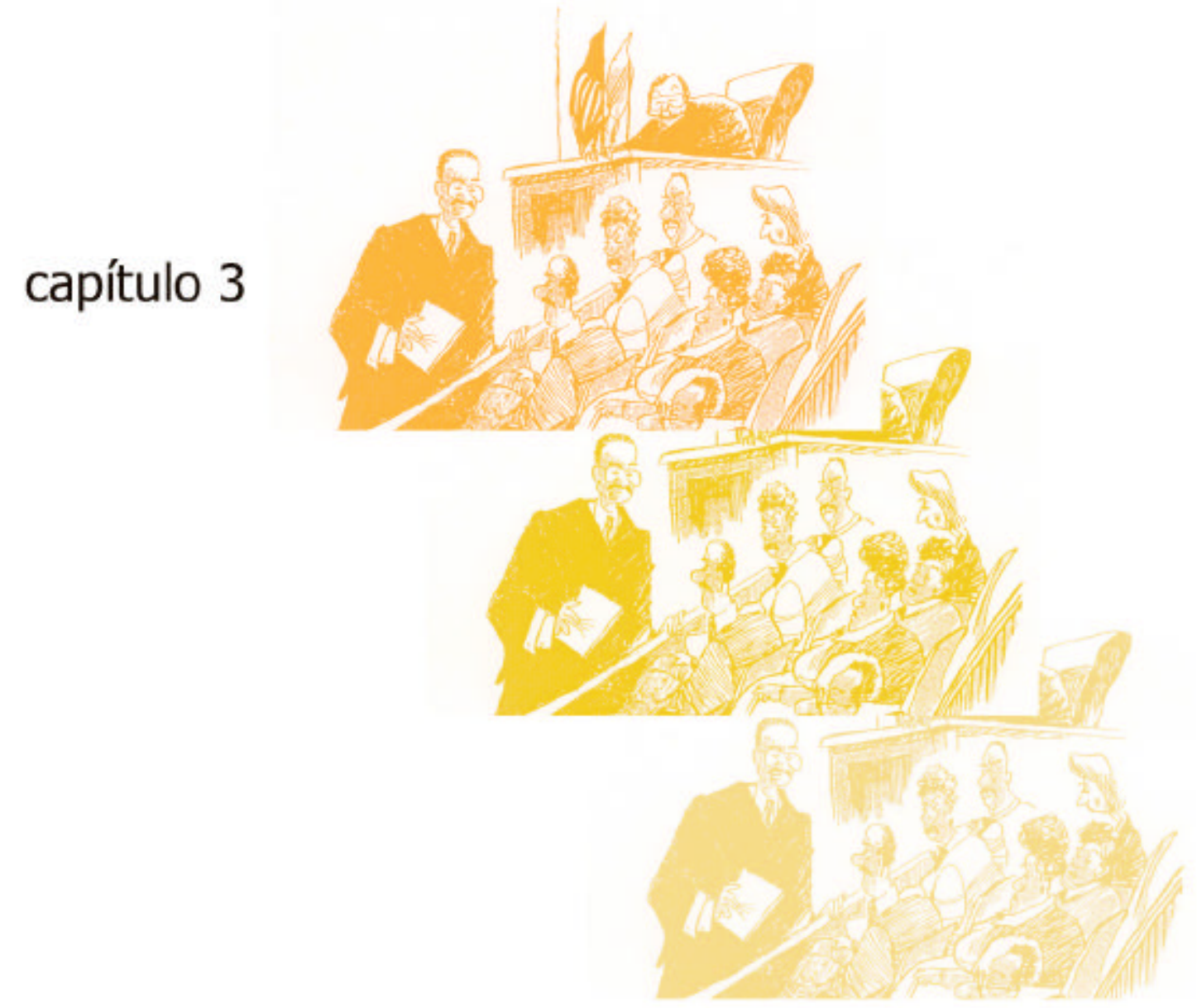




\section{JÚRI-RITUAL}

\section{- Introdução}

Marcel Mauss foi um dos primeiros teóricos da Antropologia que, ao trabalhar o conceito de ritual, propôs que se superasse a oposição entre representações - o que as pessoas pensam que fazem - e práticas - o que elas fazem - ao afirmar que umas e outras encontram-se num só domínio: no das significações, no fato social total. Nesse domínio não há modelos e classificações rígidas, de um lado, em oposição a práticas flexíveis, de outro, mas possibilidades de significações ou trocas entre sistemas de significação. Traduzir esses sistemas e trocas é uma das tarefas -chave da sociologia e da antropologia (Mauss, 1984[b]).

Pensar os julgamentos realizados pelos Tribunais do Júri a partir dessa abordagem é tentar entendê-los como situações sociais que põem em relação ao menos dois sistemas de classificação: o das leis e regras processuais e o das interpretações dessas leis, dessas regras e de acontecimentos da vida social. Assim, o que se percebe nas sessões de Júri não é a rigidez de códigos legais em oposição a interpretações flexíveis que operadores do direito e leigos lhes dão. Códigos, interpretações, atuações desses operadores e leigos são sistemas de classificação que se compõem nos plenários fazendo sentido enquanto conjunto formado numa dimensão de trocas e interações.

Do início ao final dos julgamentos, conforme já mencionamos nos dois primeiros capítulos, sentidos são atribuídos a vidas e mortes, casamentos, concubinatos, bigamias, relações de parentesco, atos de vingança, pactos entre integrantes de gangues etc. Os julgamentos pelo Júri constituem e são constituídos por essa dimensão produtora de sentidos, pois, quando fatos-dramas da vida social chegam aos plenários, eles não estão mais em seus contextos de origem nem se enquadram perfeitamente em pressupostos legais. Eles se tornaram algo de outra natureza, cujo sentido só se alcança focando a análise no domínio ritualizado em que se expressam, domínio em que tempo e espaço, já vividos, são então imaginados.

Durante as horas das sessões são narrados acontecimentos que atravessaram dias, noites, meses e anos. Embora não se percorram favelas, becos, casas, praças e ruas, nem se escutem tiros e gritos ou se veja sangue e cadáveres cobertos com folhas de jornal, tudo isso está no Júri, transmutado em narrativas, contadas segundo determinadas regras e por determinadas pessoas. Mesmo as páginas dos processos as fotos que os ilustram, os depoimentos registrados em "assentadas", os laudos periciais 
e as peças produzidas por juízes, promotores e advogados - as quais já são, em si, narrativas, tornam a ser narradas no contexto do julgamento, suscitando a produção de novos sentidos. É desse contexto ritual, que se repete a cada vez que há um julgamento num plenário de Júri, que trata este capítulo.

\section{- Onde a vida social se substantiva e se materializa}

Durante um bom tempo, rituais foram definidos por antropólogos e sociólogos como comportamentos referentes à prática de religião ou magia, em oposição a crenças que representariam aspectos dogmáticos do fato religioso (Smith, 1972 e Durkheim, 1968). Como os estudos sócio-antropológicos sobre religião e magia, e, consequentemente, sobre os domínios do social e do ritual desenvolveram-se em terreno conturbado, refletindo os próprios dilemas enfrentados pela antropologia e pela sociologia comparadas do final século XIX e início do XX, houve confrontos teóricos a respeito da conceituação de ritual ${ }^{1}$.

Pensadores como Tylor, Frazer e Malinowski opuseram-se às interpretações de caráter mais sociológico desenvolvidas por Durkheim, Mauss e Radcliffe-Brown e, mesmo entre esses últimos, houve controvérsias.

Embora concordando com Durkheim quanto ao ritual ser um elemento de reforço da solidariedade social, Radcliffe-Brown, por exemplo, concebia a estrutura social como uma rede de relações empiricamente observável, de modo que, em seus estudos sobre religião e rituais, a ênfase residia nos sistemas de práticas vistos como consolidadores, sustentadores ou mesmo produtores de sistemas de crenças (Radcliffe-Brown, 1973).

Essa tradição sociológica, inaugurada por Durkheim, deixou fortes marcas na antropologia social inglesa — na chamada Escola de Manchester —, representada por Max Gluckman e seus discípulos. Um deles, Victor W. Turner, dedicou a maior parte de sua obra ao estudo do processo ritual, não mais enquanto produtor de solidariedade, mas enquanto locus da produção de alternativas ideológicas voltadas ou não para a manutenção do status quo. Turner via no ritual a possibilidade de atualização de estados potenciais e liminares da sociedade. Tais estados, canalizados e expressos em rituais dramas sociais - exporiam variantes possíveis para o destino do grupo. O ritual, para

\footnotetext{
1 - Em minha dissertação de mestrado, retomo, no capítulo $1^{\circ}$, os principais debates relativos aos conceitos de magia, religião e ciência desenvolvidos por autores clássicos da antropologia e da sociologia Schritzmeyer, Ana Lúcia Pastore - Sortilégio de Saberes: curandeiros e juízes nos tribunais brasileiros (1900-1990). Dissertação apresentada ao programa de Pós-Graduação em
} 
Turner, portanto, era um processo que implicava mudança de uma estrutura para outra, de um estado social para outro. O conceito de estrutura social por ele utilizado, contudo, continuou sendo o da clássica antropologia social inglesa, referido às relações empiricamente observáveis e, portanto, separadas do domínio das representações (Turner, 1974).

Foi Mauss quem reuniu os domínios da prática - das relações empiricamente observáveis - e o das representações - das crenças abstratas - no domínio das significações, em que sistemas simbólicos interagem, permutam sentidos já existentes e criam novos sentidos.

É nesse tipo de abordagem que Lévi-Strauss inspirou-se para definir a realidade social como um sistema de significações, sendo que, para ele, a estrutura social a ser percebida pelo antropólogo não está no domínio das relações empiricamente observáveis, mas em modelos que se legitimam enquanto arranjos e rearranjos alternativos de possibilidades de significação. Lévi-Strauss instala o social no simbólico, assim como o faz Edmund Leach ao explorar o conceito de ritual como forma privilegiada de comunicação, de envio e recepção de mensagens organizadas através de códigos a serem decifrados por antropólogos (Leach, 1978).

Marshall Sahlins e Clifford Geertz, na mesma linha, são taxativos ao atribuírem ao domínio do simbólico a natureza dos objetos de estudo da antropologia. Para Geertz, ela deve não só traduzir, mas interpretar, construir e perseguir a invenção do social, caracterizando-se como uma ciência interpretativa, à procura de significados e não como uma ciência experimental, em busca de leis ou tendências. O ritual, nessa perspectiva, passa a ser, ele mesmo, a "essência do social", pois nele evidenciam-se histórias que a sociedade conta sobre si mesma. Ao pôr em relação elementos fundamentais da vida social, o ritual torna-se o centro da produção da própria sociedade, dos significados que ela cria para justificar sua própria existência e sua forma de se organizar (Sahlins, 1979 e Geertz, 1978).

Podemos afirmar, portanto, que o ritual dos julgamentos pelo Júri substantiva e dá materialidade ao social, à medida que, nas histórias de vida e morte que chegam a esses tribunais, seus participantes produzem significados, com vistas a justificar, não apenas a absolvição ou a condenação de réus, mas a significação de todo um sistema de julgar baseado em valores que qualificam vida, morte, ordem e desordem.

Antropologia Social da Faculdade de Filosofia, Letras e Ciências Humanas da Universidade de São Paulo, sob a orientação da $\operatorname{Prof}^{a} \operatorname{Dr}^{\mathrm{a}}$ Paula Montero. Defendida em 6 de setembro de 1994. 


\section{- Júri: ritual ou cerimônia?}

Segundo Roberto Da Matta, opor os conceitos de ritual e cerimônia não é uma boa opção analítica, especialmente no estudo "dos materiais brasileiros", pois tal opção implicaria dissociar aspectos seculares da vida (cerimoniais) de aspectos místicos (rituais): "(...) é muito mais fecundo (...), em vez de definir o rito por meio de algum traço positivo e substantivo, (...) defini-lo (junto com o cerimonial e a festa) por meio do contraste com os atos do mundo diário, o ponto focal passando a ser as oposições básicas entre seqüências de ações dramáticas que todo ato cerimonial ou ritual deve necessariamente conter, construir e elaborar. $O$ ritual, assim, jogaria muito mais com o drama — que permite a consciência do mundo social - do que com algum componente místico ou mágico." (Da Matta, 1983: 36-37).

Essa postura teórica é a que adotaremos ao considerar os julgamentos pelo Júri uma seqüência de ações dramáticas que contrasta com atos do "mundo cotidiano" e permite a seus participantes conscientizarem-se de traços estruturantes desse mundo, como, por exemplo, a hierarquia que distribui e classifica indivíduos, tornando-os ou não "pessoas". Mas antes de desenvolvermos essa afirmação, tratemos, um pouco mais, dos conceitos de cerimônia e ritual.

\section{- Cerimônia}

De acordo com Radcliffe-Brown, a definição de cerimônia é bastante antiga. Filósofos confucionistas ${ }^{2}$ dos sécs. I e III a.C. referiam-se à ela como uma expressão ordenada de sentimentos, própria de determinada situação social (Radcliffe-Brown, 1939: 33). Passados tantos séculos, uma das definições atuais de cerimônia parte de pressupostos semelhantes: "(...) manifestação de sentimentos ou atitudes em comum através de ações mais ou menos formalmente ordenadas e de natureza essencialmente simbólica em ocasiões apropriadas. (...) pode, mas não necessariamente, conter orientações para objetos, orientações empíricas ou não empíricas, capazes de inspirar atitudes de lealdade, respeito ou reverência. De qualquer modo, envolve uma atenção especial para a forma de comportamento e a seleção de formas apropriadas para expressar sentimentos ligados a determinada situação social. O sentimento é inseparável da ação." (Honnigmann, 1986: 169-170).

\footnotetext{
2 - A referência de Radcliffe-Brown à filosofia de Confúcio - ou seja, a um pensamento não ocidental, que começa no século VI antes da era cristã, segundo o qual a harmonia do corpo social e do próprio universo resultaria do esforço constante de cada indivíduo cultivar a harmonia em seu interior e de passá-la aos demais -, mostra como, da perspectiva de um dos mais notáveis antropólogos do século XX, a concepção dos indivíduos como partes de um "corpo social" e responsáveis por seu funcionamento antecede, em muito, o surgimento da ciência política, da sociologia e da própria antropologia, enquanto ciências.
} 
Nos plenários do Júri, conforme já apontamos nos dois primeiros capítulos, os participantes do julgamento compartilham sentimentos e atitudes que expressam através de ações formalmente ordenadas, cuja natureza é essencialmente simbólica. Dentre o complexo de sentimentos e atitudes em jogo, predomina um "clima" de reverências que reforçam posições hierárquicas.

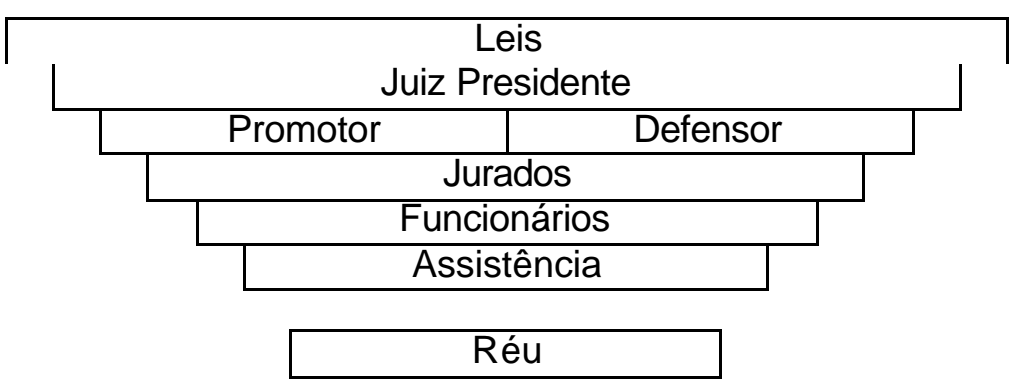

A começar pelos juízes, suas atitudes e discursos reverenciam principalmente "a lei”, pois eles se colocam e se portam em plenário como seus representantes máximos. Assim, o próprio Código de Processo Penal prescreve, no art. 497:

"São atribuições do presidente do Tribunal do Júri, além de outras, expressamente conferidas neste Código:

I - regular a polícia das sessões e mandar prender os desobedientes;

II - requisitar o auxílio da força pública que ficará sob sua exclusiva autoridade;

III -regular os debates;

IV -resolver as questões incidentes que não dependam da decisão do júri;

$V$-nomear defensor ao réu quando o considerar indefeso, podendo, neste caso, dissolver o conselho, marcado novo dia para o julgamento e nomeado outro defensor;

VI -mandar retirar da sala o réu que, com injúrias ou ameaças, dificultar o livre curso do julgamento, prosseguindo-se independentemente de sua presença;

VII -suspender a sessão pelo tempo indispensável à execução de diligências requeridas ou julgadas necessárias, mantida a incomunicabilidade dos jurados;

VIII -interromper a sessão por tempo razoável para repouso ou refeição dos jurados;

IX-decidir de ofício, ouvidos o Ministério Público e a defesa, ou a requerimento de qualquer uma das partes, a preliminar da extinção da punibilidade;

$X$-resolver as questões de direito que se apresentarem no decurso do julgamento;

$X I$-ordenar de ofício, ou a requerimento das partes ou de qualquer jurado, as diligências destinadas a sanar qualquer nulidade, ou a suprir falta que prejudique o esclarecimento da verdade."

Portanto, diferentemente do que ocorre na maioria dos locais da cidade de onde mais provêm réus e vítimas de homicídio doloso, nos plenários do Júri a lei está lá, visível, não só através da presença policial, mas encarnada em um juiz, com sua toga preta, sua mesa centralizada e alta, suas palavras comedidas e aparentemente neutras.

As saudações iniciais que promotor e defensor dirigem aos presentes, por sua vez, explicitam e reiteram o conjunto hierárquico. Inicialmente é homenageado o Juiz 
Presidente, depois o "Ministério Público" ou a "OAB", os jurados, funcionários e assistentes. Quando a saudação aos jurados vem por último, normalmente é porque o orador aproveita-a para dar início a sua sustentação oral. Promotor e defensor, ao retomarem essa hierarquia, nela também se posicionam, geralmente enquanto partes que desfrutam de status semelhante e, por isso mesmo, confrontam opiniões e até trocam insultos.

Numa sessão a que assisti, quando a sustentação oral do defensor já caminhava para a finalização, após o promotor ter pedido vários apartes que, tensamente, o defensor concedeu-lhe, houve um desses confrontos:

$\Rightarrow$ Promotor: O Sr. está fazendo um carnaval com a ficha de antecedentes da vítima!

$\Rightarrow$ Defensor: Carnaval, não! Isto é o meu trabalho.

$\Rightarrow$ Promotor: Carnaval, sim! Pois a vítima...

$\Rightarrow$ Defensor: Se o Sr. insistir nesse termo, eu pedirei para que isso conste em ata como ofensa a minha pessoa, pois acima das nossas divergências está a lei, representada pelo Exmo Sr. Juiz. Estão também o Ministério Público e a OAB, instituições que nós dois representamos e que devemos honrar. Há ainda os senhores jurados que não vieram aqui para participar de nenhum carnaval, assim como os estudantes e o próprio réu!

$\Rightarrow$ Promotor: Ora, doutor... Estou só falando que o Sr. está invertendo a importância das coisas ao querer transformar a vítima num bandido.

$\Rightarrow$ Defensor: Eu sei muito bem o que estou fazendo, não estou invertendo nada e o aparte concedido está terminado (...)

Embora, provavelmente, nem defensor nem promotor tenham empregado conscientemente a palavra carnaval para se referir ao que Roberto Da Matta denomina de um "rito de inversão da ordem", foi exatamente esse o sentido que ela alcançou no confronto, tanto que o defensor, de modo incisivo, situou seu trabalho no Júri como parte de um rito de reforço — não de inversão — de uma ordem rigidamente hierarquizada.

Quanto aos funcionários, eles agem, na maior parte do tempo, como fiéis assessores do juiz e, consequentemente, executores da lei e da ordem. Sempre que necessário ou que solicitados, lá estão, com uma presteza que contrasta com a imagem que se tem do funcionalismo público brasileiro.

Quando do encerramento da sessão, a maioria dos juízes agradece e retribui as saudações iniciais de promotores e advogados, seguindo a mesma ordem hierárquica e, entre o início e o fim do julgamento, várias atitudes e comportamentos dos presentes também reiteram essa ordem e o respeito que por ela sentem. Muito raramente, por exemplo, assistentes dirigem a palavra - seja em voz alta ou sussurrada - ao juiz, promotor, defensor, jurados ou funcionários. Se isso é indevidamente feito, o juiz

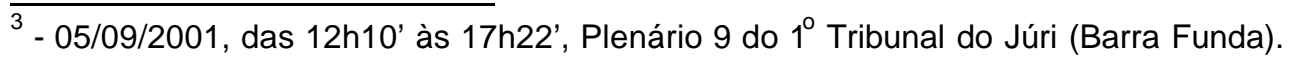


imediatamente intervém. Na mesma sessão citada, em que promotor e defensor se exaltaram, o juiz, antes de interrogar o réu, olhou fixamente para quatro mulheres sentadas na assistência, visivelmente apreensivas, negras como o réu, e fez o seguinte alerta: "O público presente deve manter comportamento adequado, durante todo o julgamento, ou seja, os senhores não podem se manifestar nem entabular conversas paralelas, pois, caso isso ocorra, eu ordenarei o esvaziamento do plenário".

Mesmo entre $\mathrm{si}$, os assistentes mal se comunicam e, embora, durante $\mathrm{o}$ julgamento, seja-lhes permitido sair do plenário, até isso implica um certo constrangimento, pois o olhar de um PM esquadrinha toda e qualquer movimentação.

Enfim, enquanto cerimônia, pode-se dizer que, no Júri, há uma orientação compartilhada, por todos os participantes, que inspira atitudes de lealdade, respeito e reverência à lei, ali encarnada, hierarquicamente, nas figuras do juiz, promotor, defensor, jurados, funcionários e PMs. O réu, contrariamente a esses, encarna o desrespeito à lei, e não a qualquer lei, pois "não matar", há milênios, nas mais diversas culturas, constitui uma regra básica de ordenação social.

Talvez, possamos afirmar que, no substrato dos julgamentos pelo Júri, na reverência aos representantes da lei e no repúdio a seus prováveis infratores, temos uma expressão da crença dos homens em sua própria sociedade, em sua capacidade de ordená-la. Homens se matam, mas homens se julgam e fazem "justiça".

Outro elemento considerado constitutivo de cerimônias, além de sentimentos ordenadamente expressos numa situação social própria, é a manipulação de corpos humanos e objetos - pessoas que se curvam ou se ajoelham, tiram ou põem adereços em seus corpos, apresentam armas, sacrificam o gado etc. Pressupõe-se que através da análise dos significados de tais atos cerimoniais pode-se captar os sentimentos por eles expressos.

No Júri, a manipulação física e simbólica dos corpos, conforme já apontamos, é bastante evidente e, dentre outras conclusões, sua análise nos remete, novamente, ao caráter de reforço de uma ordem hierárquica. O espaço em que transcorrem as sessões é um campo de posições significativamente marcadas. O réu não se ajoelha, fisicamente, diante do juiz e dos jurados, mas, simbolicamente, está o tempo todo submisso e, não raramente, além de ser alvejado por argumentos do promotor, também é exposto, pelo próprio defensor, na tentativa de fazer com que os jurados dele se compadeçam. Em várias sessões, presenciei defensores apontarem seus clientes como vítimas de emoções descontroladas e/ou de condições miseráveis de vida. 
Com seus corpos devidamente marcados pelo uso de togas, juízes, promotores e defensores, por sua vez, tomam conta do "palco" e, ao apresentarem e manusearem "suas armas" - o processo, os códigos e os livros que levam ao plenário - impõem seu saber técnico, especialmente sobre os jurados. Não só os conteúdos desses textos e peças legais, mas eles próprios, enquanto objetos, integram a cerimônia.

Certa vez, no início de meu trabalho de campo, presenciei a atuação de um promotor que, no auge de sua réplica, deixou, intencionalmente, cópias do processo voarem pelo plenário. Com uma das mãos, ele as segurava, no alto da cabeça, enquanto esvoaçava sua toga junto ao rosto dos jurados e dos assistentes da primeira fileira . À medida que avançava para o pedido de condenação do réu e que sua voz se elevava, as folhas começaram a cair pelo chão. Encerrou sua sustentação dizendo: "Estou afirmando, junto com a Polícia Militar do Estado de São Paulo e com o Ministério Público deste Estado que o réu cometeu o crime". Nesse instante, a última folha voou pelo plenário. Todos ficaram visivelmente eletrizados com a cena que, na verdade, só terminou quando, em silêncio, o promotor, ainda esvoaçante e ofegante, recolheu todas as folhas e sentou-se, percorrendo o plenário com olhar de quem cumpriu sua missão. ${ }^{4}$

Afirmam estudiosos de cerimônias que, devido aos participantes determinarem seu ritmo, isso acarreta um aumento de interação entre eles. Tal intensificação, em certos casos, é alcançada através da utilização de recursos como o álcool, a dança ou outras formas deliberadas. No Júri, conforme já apontamos, são, principalmente, a dicção, a entonação de voz, a gestualidade, a vestimenta e a movimentação de promotores e defensores em plenário que determinam o ritmo do julgamento, embora juizes, réus e, secundariamente, jurados, funcionários, PMs e assistentes também influenciem a dinâmica do conjunto. Mas as interações mais intensas dão-se entre promotores e defensores, em especial durante apartes que uns concedem aos outros, ao longo das respectivas sustentações orais, réplicas e tréplicas. Pode-se afirmar, inclusive, que através de promotores e defensores do Júri, por vezes, intensificam-se tensões que extrapolam a sessão de julgamento, pois mobilizam o Ministério Público, a Procuradoria de Assistência Judiciária do Estado - PAJ - a OAB e mesmo outras entidades do "mundo jurídico".

Em 2001, numa das reuniões de diretoria do Instituto Brasileiro de Ciências Criminais - IBCCRIM (05/08) —, longo tempo foi dedicado às repercussões, para o

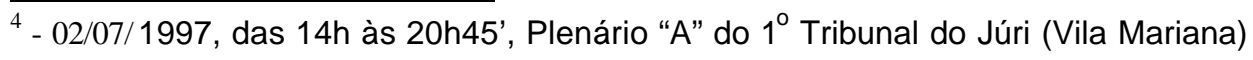


Instituto, da briga entre uma procuradora e um promotor, num dos plenários do Júri ${ }^{5}$. Um texto dela, mencionando as "ofensas" que o promotor the teria dirigido durante 0 julgamento, circulou no site do Instituto, fazendo com que o promotor reagisse, avisando que, caso o IBCCRIM não se retratasse, o Instituto e o diretor do site seriam processados por calúnia e difamação. Em outras palavras, o que estava em jogo não era um desentendimento entre dois profissionais, porém a definição do posicionamento de um Instituto em relação a duas instituições - Ministério Público e Procuradoria de Assistência Judiciária do Estado. A decisão do Presidente do IBCCRIM foi: “(...) textos que expressem opiniões de caráter pessoal e político não devem circular no site, uma vez que 0 Instituto não deseja se identificar como porta-voz de nenhuma corporação ou grupo em particular."

Evitação é outro elemento bem difundido em cerimônias e bastante presente nos julgamentos pelo Júri, pois, nele, as pessoas evitam praticar certas ações, circular por determinados espaços, tocar alguns objetos e entrar em contato com outras pessoas, aumentando, assim, a significância da ocasião e reforçando-a como especial ou sagrada. A exigência de que os jurados permaneçam incomunicáveis, uma vez composto o Conselho de Sentença, é, talvez, o exemplo mais claro de uma série de comportamentos controlados por códigos de evitação.

Além disso, um dos momentos iniciais da cerimônia, quando os jurados selecionados passam da "platéia" para o "palco", representa uma alteração visível de status, ainda que não marcada pela mudança de indumentárias. Ao se sentarem em seus novos lugares de juízes, desaparecem os cidadãos comuns. Nada do que farão, dali para frente, será comum, mesmo quando relaxarem, nos intervalos para descanso, pois não poderão comentar o caso em julgamento, quer entre si, quer com outras pessoas, razão pela qual não podem, em hipótese alguma, contactar parentes, amigos, colegas de trabalho, ou seja, "o mundo exterior".

Em qualquer sessão de Júri, desde as menos concorridas, até as mais procuradas, os plenários evidenciam-se como espaços - círculos mágicos - muito governados por regras segundo as quais os presentes sabem como, quando e por que devem se manifestar.

Retomando a idéia de que a cerimônia geralmente envolve o uso de certos objetos, com significação simbólica, cabe lembrar que a disposição e o tipo de mobília, bem como as cores de pisos e paredes e a posição de divisórias e portas também contribuem para o "clima" do julgamento. Embora a maioria dos plenários paulistanos

\footnotetext{
5 - Ela atuava como advogada do réu e ele como acusador, representando o Ministério Público.
} 
seja, materialmente, desprovida de pompa, ainda assim, ao neles se entrar, tem-se a sensação de que se penetrou num espaço incomum e solene. As salas atuais ou são antigas, com predomínio de móveis de madeira e paredes brancas, ou modernas, com mesas, cadeiras e divisórias revestidos de fórmica, com partes de aço à vista e cores que variam do cinza ao azul marinho. Mais do que o material de que são feitos esses objetos, o que importa é a maneira como estão dispostos e o que isso comunica.

Um plenário, seja novo ou antigo, assemelha-se a uma sala de aula tradicional ou a uma pequena igreja ou templo. No centro das atenções, dominando a cena, justamente porque representa o domínio do saber e do poder, está o juiz, o mestre, o sacerdote. 0 que se passa em torno dessa figura central parece estar sempre aquém de sua plácida, altiva e observadora sabedoria. Não fosse a presença do juiz, os plenários paulistanos, provavelmente, não teriam solenidade. O juiz, enquanto encarnação da lei, da autoridade que sabe, coordena e decide, sacraliza a cerimônia do Júri. Como diria Da Matta, “(...) em todos os ritos sempre encontramos um centro, uma zona focal, geralmente controlada por um sacerdote ou quem faz a vez dele. Pois é aqui que se faz a ligação e a afirmação dos que têm com os que não têm, (...), no jogo muito complicado das múltiplas legitimações."(1983: 26).

Um exemplo dessa sacralidade são os dois momentos das sessões em que, mediante ordem do juiz ou de um funcionário do Tribunal, os presentes levantam-se e sentam-se, como em rituais das Igrejas Cristãs. O primeiro desses momentos se dá no início da sessão, antes do interrogatório do réu, quando já foram sorteados, aceitos e posicionados os jurados que comporão o conselho de sentença. O juiz então se levanta, bem como todos os presentes e, dirigindo-se aos jurados, faz a seguinte exortação: "Em nome da lei, concito-vos a examinar com imparcialidade esta causa e a proferir a vossa decisão de acordo com a vossa consciência e os ditames da justiça". Os jurados, nominalmente chamados pelo juiz, e de acordo com o art. 464 do CPP, deveriam responder : "Assim o prometo". Na maioria das vezes, contudo, respondem: "Assim eu prometo". Embora pareça irrelevante essa falha no uso do pronome átono de objeto direto da $3^{a}$ pessoa, ela manifesta que, apesar da estreiteza do espaço aberto para que os jurados falem — três palavras —, eles falam como "o Brasil fala" - usando o nome em lugar do pronome. À solenidade da lei, marcada pelo verbo concitar, pelo pronome vós e pelo substantivo ditames, os jurados respondem com um informal "erro" de português e, com isso, comunicam: "Prometemos votar, sim, com base em nossas experiências cotidianas!". Em seguida, todos se sentam, novamente, e o juiz dispensa os demais jurados. 
O segundo momento em que esse ritual torna a se manifestar é quando, no término da sessão, após encerrada a votação secreta, todos retornam ao plenário para que o juiz anuncie a sentença. O réu é posicionado em pé, de frente para o juiz - de costas para a platéia, portanto - e todos se levantam. O juiz, então, anuncia a sentença e, no caso de condenação, também a pena que o réu terá de cumprir — número de anos, meses e regime de cumprimento.

Esses dois momentos, pelo fato de todos se levantarem para ouvir o juiz e pelo significado do que se passa - prestar compromisso e anunciar uma sentença -, são altamente solenes, independentemente do ambiente físico em que ocorrem. Aliás, o ambiente físico é que depende desses atos para ganhar solenidade.

No limite, talvez possamos afirmar que temos a lei como alvo das cerimônias que se desenvolvem nesses tribunais e como objeto não empírico - quase como entidade sobrenatural - que tende a canalizar emoção durante seu transcorrer. "A" lei, invocada por juízes, promotores e defensores apresenta-se como um espécie de entidade que está no limiar entre o mundo dos deuses e o dos homens. Do primeiro ela parece provir, com seu caráter abstrato, universal. No segundo, a partir de minúcias profanas, narradas e julgadas por homens, ela é aplicada e surte efeitos concretos, visíveis.

"A" lei é o objeto-alvo da cerimônia do Júri, mas com uma complexidade: é a pessoa do réu ou ré, ou seja, de quem é acus ado de descumpri-la, o objeto empírico que canaliza fortes emoções no Júri - pena, desprezo, compaixão, ódio. E isso assim se dá porque réus e rés, moldados pelos discursos de promotores e defensores, explicitam valores que estão, constantemente, questionando a adequação de todos à vida social — fidelidade conjugal, amor filial, lealdade entre amigos, honra no pagamento de dívidas, respeito a hierarquias de grupo, produtividade econômica etc.

Para além de réus e de suas histórias, portanto, o que está em julgamento são valores que essas histórias permitem pensar. Valores que não estão esmiuçados nas leis, mas que, se não existissem, elas não se sustentariam.

A cerimônia do Júri, portanto, embora de natureza secular, guarda paralelos com cerimônias sagradas, inclusive devido a características que transcendem o próprio Júri e dizem respeito ao Sistema Judiciário. Ministério Público, Magistratura, $O A B$ e Procuradoria, por exemplo, funcionam como "ordens" das quais participam somente cidadãos que, para integrá-las, submetem-se a ritos de admissão e progressão considerados exigentes, sacrificados. Por isso, enquanto representantes dessas "ordens", 
esses cidadãos constituem uma nova classe de pessoas, hierarquicamente diferenciada das demais.

Em suma, podemos considerar que os julgamentos pelo Júri, enquanto cerimônias, desempenham certas funções, não somente para seus participantes, como para aqueles que, de alguma maneira, são atingidos por sua lógica e seus efeitos. De um modo geral, esses julgamentos:

a) expressam, transmitem e perpetuam elementos que compõem o sistema de valores e sentimentos considerado legalmente hegemônico;

b) preservam de dúvida e oposição insolúveis tais valores e sentimentos, uma vez que, por mais polêmico que seja um caso, chega-se sempre a uma sentença;

c) intensificam a solidariedade entre as pessoas que participam da cerimônia.

Mais especificamente, os julgamentos constituem:

a) um rito de passagem que ajuda os réus a efetuarem uma mudança de status, tanto quando são absolvidos - caso em que passam de suspeitos a inocentes - quanto condenados - situação em que perdem direitos e garantias individuais, constitucionalmente assegurados, e, aos olhos da sociedade, consolidam-se como marginais a ela.

b) um rito de deferência, em que se reconhecem a superioridade e a subordinação de todos às leis vigentes e a seus representantes, ajudando assim a manter a estrutura social;

c) um rito de intensificação diretamente ligado a um tipo de crime - doloso contra a vida - indicador de crise na interação social. Nesse sentido, tal rito aumenta a solidariedade do grupo, diminuindo tensões e colaborando para a neutralização dessa crise.

Enfim, os termos cerimônia e ritual são, frequentemente, usados como sinônimos, embora alguns de seus empregos tenham aspectos distintos (Honigmann, 1986: 169170). Mas, conforme apontamos, no início deste item, por esta tese tratar de julgamentos realizados pelo Júri, na maior cidade brasileira, seguiremos a trilha analítica percorrida por Roberto Da Matta, segundo o qual cerimônia e ritual são conceitos que devem se compor e não se opor no estudo antropológico de "materiais brasileiros". 


\section{- Julgamentos pelo Júri: "cerimônia ritual" ou "rito cerimonial"}

Uma classificação possível dos grandes eventos sociais brasileiros é (Da Matta: 37-39):

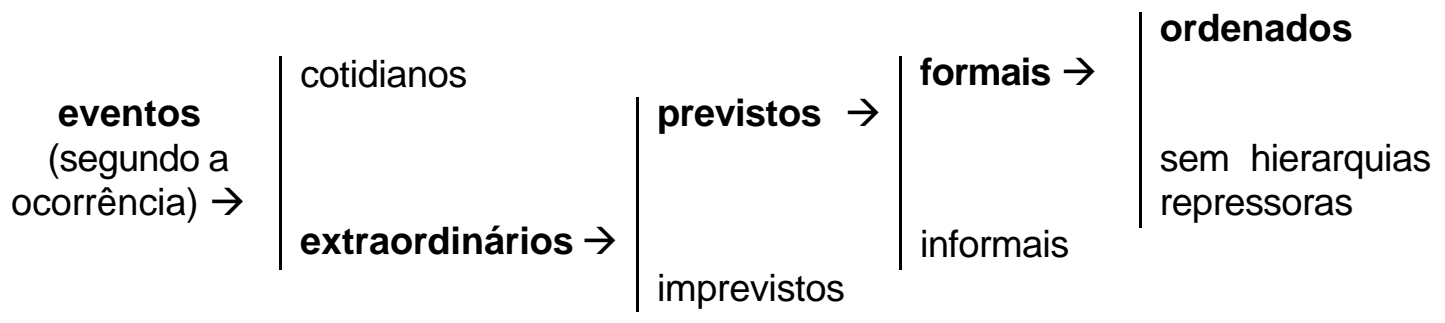

Se adotarmos essa classificação, podemos afirmar que os julgamentos pelo Júri são eventos extraordinários, previstos, formais e ordenados. Situam-se fora da rotina repetitiva do dia-a-dia — ao menos para réus, seus parentes, jurados e "platéia" —; têm caráter aglutinador de pessoas, de grupos ou mesmo de categorias sociais. E são previstos, ou seja, socialmente controlados. São ainda formais e solenes, pois neles há exigência de divisão interna e sua estrutura hierarquizante aparece de modo manifesto. São eventos fortemente centralizados - nas figuras do réu, promotor e defensor - e se baseiam em momentos bem marcados. Além disso, há uma assistência e uma separação nítida entre o domínio do cotidiano e o do julgamento: "A passagem de um domínio a outro é marcada por modificações no comportamento, e tais mudanças criam as condições para que eles sejam percebidos como especiais" (Da Matta, 1983: 38).

Nos julgamentos pelo Júri estamos, portanto, diante de uma cerimônia dominada pelo planejamento e pelo respeito, havendo um tempo e uma seqüência pré-determinados para que cada um se manifeste e regras sobre como devem se dar essas manifestações, desde as que dizem respeito à continência verbal até as que orientam a comunicação gestual.

Nos rituais há, ainda, geralmente, o uso de vestes apropriadas: “(...) as vestimentas são gramaticalmente coerentes com os gestos e o comportamento em geral. (...) a farda iguala e corporifica - pois os membros de uma corporação usam vestes idênticas, suas diferenças sendo de grau e não de qualidade -, (...). Desse modo, o traje militar, a beca e outras vestimentas típicas de certas posições sociais têm, entre outras, a função de nelas esconderem seu portador, protegendo o papel desempenhado da pessoa que o desempenha e, ainda, separando o papel que define sua posição no ritual dos outros papéis que desempenha na vida diária. Coerentemente com isso, há ainda o fato crítico de as fardas (e outras vestes formais) serem exclusivas de certas posições "(idem: 47). 
Num intervalo de certa sessão ${ }^{6}$, eu tive acesso à "sala de lanche" dos jurados e presenciei uma conversa entre esses, juiz, promotor e defensor, durante a qual um jurado perguntou, aos operadores técnicos, por que suas becas pretas se distinguiam pelas diferentes cores dos cordões - branco para o juiz, vermelho para o promotor e negro para o defensor. A pergunta específica do jurado foi: "Essas cores têm algum significado?"O juiz se antecipou comentando: "Originalmente, deveriam ter, mas, atualmente, acho que só servem para que cada um identifique qual é a sua toga".

É de se notar que, embora contrapostas pelo "mas", as duas orações dizem a mesma coisa, pois ter um significado permite identificar. O que o juiz talvez tenha comunicado é que, aparentemente, o significado simbólico original, mais amplo e solene, perdeu-se, passando as cores a ter um novo significado, aparentemente pobre e frugal: mera identificação de "roupas". O que ele parece não ter captado, é que esse novo significado é muito relevante, independente do significado de origem, pois togas, no caso, não são "roupas", mas funções no Sistema Judicial que não devem ser confundidas e trocadas.

O advogado aproveitou o ensejo para contar que, quando menino, fora coroinha, e que, mais tarde, fizera seminário, ocasião em que aprendeu o significado das diferentes cores usadas nas roupas de padres, bispos, arcebispos e cardeais. O defensor chegou mais perto de uma resposta: as cores expressam uma hierarquia e, mesmo que quem as veja não saiba, em detalhes, o que significam, sabe que a hierarquia está lá, o que é e sempre foi, segundo Renato Janine Ribeiro, exatamente o sentido da etiqueta (Ribeiro, 1983).

\section{- Júri: rito formal, de separação e de reforço}

Os diferentes rituais de uma sociedade "(...) são discursos diversos a respeito de uma mesma realidade, cada qual salientando certos aspectos críticos, essenciais dessa realidade. (...) a vida ritual de uma dada sociedade não precisa ser necessariamente coerente ou funcional, podendo conter elementos competitivos ou concorrentes, expressivos de modos diversos de perceber, interpretar e atualizar a estrutura social. (...) essa perspectiva permite verificar a importância básica da natureza combinatória da própria vida ritual." (Da Matta, 1983: 52). Em outras palavras, o mesmo povo que faz o carnaval comemora o "Sete de Setembro" e festeja datas religiosas, sem que isso implique algo incompreensível e incompatível. Poderíamos acrescentar que parte desse mesmo povo está presente a sessões de Júri.

\footnotetext{
${ }^{6}$ - 19/07/2001, das 12h às 16h30', Plenário 8 do $1^{\circ}$ Tribunal do Júri (Barra Funda).
} 
Portanto, do mesmo modo que o Carnaval, o Dia da Pátria e as festas religiosas, o ritual dos julgamentos pelo Júri é um modo possível de salientar e tornar manifestos, por meio de um discurso específico, aspectos considerados importantes da estrutura social brasileira. Nos caso dos julgamentos realizados na cidade de São Paulo, especificidades da vida em uma grande metrópole brasileira estão em destaque.

Inserindo, portanto, os julgamentos pelo Júri no rol de outros importantes rituais brasileiros, podemos, de modo esquemático e amplo, afirmar:

\begin{tabular}{|c|c|c|c|}
\hline $\begin{array}{c}\text { Rituais } \\
\text { brasileiros }\end{array}$ & $\begin{array}{l}\text { mecanismos } \\
\text { básicos }\end{array}$ & aspectos salientados & foco do rito \\
\hline Carnaval & $\begin{array}{l}\text { inversão da } \\
\text { hierarquia } \\
\text { (o povo se } \\
\text { equipara às } \\
\text { autoridades e } \\
\text { celebridades) }\end{array}$ & $\begin{array}{l}\text { - ambíguos, cósmicos } \\
\text { e universais (embora } \\
\text { contextualizados) }\end{array}$ & $\begin{array}{l}\text { - sentimentos, ações, } \\
\text { valores, grupos e } \\
\text { categorias } \\
\text { cotidianamente } \\
\text { problemáticos e } \\
\text { inibidos } \\
\text { - margens, limites }\end{array}$ \\
\hline Dia da Pátria & $\begin{array}{l}\text { reforço da } \\
\text { hierarquia } \\
\text { (o povo se } \\
\text { distingue das } \\
\text { autoridades) }\end{array}$ & $\begin{array}{l}\text { da ordem social } \\
\text { brasileira (frente a } \\
\text { outras nações): } \\
\text { rotinizados, } \\
\text { implícitos, } \\
\text { internalizados }\end{array}$ & $\begin{array}{l}\text { - } \text { hierarquia } \\
\text { - o que é } \\
\text { especificamente } \\
\text { brasileiro }\end{array}$ \\
\hline $\begin{array}{l}\text { Festas } \\
\text { religiosas }\end{array}$ & $\begin{array}{l}\text { neutralização } \\
\text { de posições, } \\
\text { grupos e } \\
\text { categorias }\end{array}$ & $\begin{array}{l}\text { - conciliação (entre } \\
\text { povo e Estado } \\
\text { através do culto) }\end{array}$ & 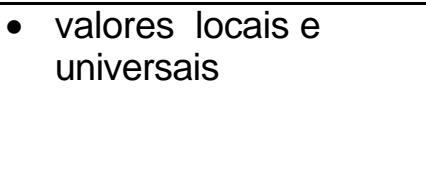 \\
\hline $\begin{array}{l}\text { Julgamentos } \\
\text { pelo Júri }\end{array}$ & $\begin{array}{l}\text { - reforço da } \\
\text { ordem jurídico- } \\
\text { social }\end{array}$ & $\begin{array}{l}\text { uso legal e legítimo } \\
\text { do poder de matar } \\
\text { - valores morais, } \\
\text { econômicos, } \\
\text { relacionados a laços } \\
\text { de parentesco, } \\
\text { vizinhança, trabalho. }\end{array}$ & $\begin{array}{l}\text { explicitação de } \\
\text { valores hegemônicos } \\
\text { e definidores de quem } \\
\text { pode ou não matar } \\
\text { (quando, como e, } \\
\text { principalmente, por } \\
\text { quê) }\end{array}$ \\
\hline
\end{tabular}

Cada um desses rituais, permite isolar e estudar "relações sociais críticas", pois são “(...) discursos simbólicos e expressivos de posições na estrutura social, não precisando ser necessariamente coerentes ou funcionais." (idem: 55-56)

Tal postura teórica implica considerar a "matéria-prima" do mundo cotidiano indistinta daquela que constitui o mundo dos rituais, sendo possível admitir que existem tantos rituais quantos são os domínios percebidos e classificados do mundo social (ibidem: 56), daí haver, na antropologia, tantos adjetivos para os rituais: sagrados, populares, econômicos, de parentesco, políticos, seculares, formais, informais, esportivos, acadêmicos, civis, militares, femininos, masculinos, de passagem, de 
interação, de segregação e agregação, financeiros, mágicos e místicos, científicos, de expiação, de aflição, etc. E eu acrescentaria "rituais jurídicos".

Outros antropólogos, como Leach, Turner e Gluckman também consideram problemático separar as ações rituais de outras, através de critérios como o da existência ou não de componentes místicos: “(...) os rituais não devem ser tomados como momentos essencialmente diferentes (em forma, qualidade e matéria-prima) daqueles que formam e informam a chamada rotina da vida diária. (...), o estudo dos rituais não seria um modo de procurar as essências de um momento especial e qualitativamente diferente, mas uma maneira de estudar como elementos triviais do mundo social podem ser deslocados e, assim, transformados em símbolos que, em certos contextos, permitem engendrar um momento especial e extraordinário. Como todo discurso simbólico, o ritual destaca certos aspectos da realidade. Um de seus elementos básicos é tornar certos aspectos do mundo social mais presentes do que outros. (...) 0 rito, como o mito, consegue colocar em close up as coisas do mundo social" (Da Matta, 1983: $60)$.

Seguindo esse raciocínio, podemos afirmar que, quando uma pessoa conta a outra sua versão a respeito de um crime e pede que essa manifeste sua opinião sobre a culpa ou inocência do acusado, temos apenas uma conversa. Porém, quando acusador e defensor, em plenário, contam aos jurados, na presença do réu e de um juiz, versões a respeito da ocorrência do crime, para que, nesse contexto, o réu seja julgado, temos um ritual. Colocou-se em close up o uso legítimo do poder de matar e o controle de sua ilegitimidade. Houve uma transposição de elementos de um domínio para outro. Os "comentários" a respeito do crime - presentes, cotidianamente, em conversas de bar, nas páginas de jornais e revistas, na tela da TV, nos romances policias - e o ato de julgar passam a simbolizar toda uma revisão que os jurados fazem de valores sociais, cuja atualidade e dcance serão "testados" naquele julgamento concreto, separados para análise. O resultado será visível e palpável.

O mecanismo básico que parece estar presente nessa situação é o da separação. Elementos são retirados de determinados contextos e inseridos em outro: “(...) nada de novo foi realmente inventado e o que se fez foi o deslocamento de um elemento para um contexto do qual ele está normalmente excluído" (Da Matta, 1983: 61).

Podemos pensar os próprios jurados enquanto "elementos" que também se deslocam de seu dia-a-dia para o espaço do tribunal, para nele exercerem uma função que, normalmente, não é a sua: a de juízes que decidem sobre a liberdade ou prisão de alguém a partir da análise pormenorizada de duas versões da ocorrência de um crime. Porém, “(...) o que é separado de um lado, é integrado de outro" (idem). Se, por um lado, os 
jurados "saem" de seus cotidianos, por outro, passam a "integrar" o Poder Judiciário. As versões do crime "saem" dos espaços profanos, onde são "palpites", para ganhar o status de sustentações da promotoria e da defesa.

Nesse sentido, também afirma Gluckman ${ }^{7}$ que a separação de papéis — instância importante do processo de ritualização - ganha especial relevância em rituais de reforço: “(...) os rituais fundados no reforço (ou na separação) são rituais que guardam uma relação direta com as rotinas do mundo quotidiano. Assim, por exemplo, um general é sempre um general; apenas acontece que, num determinado momento estabelecido pelo grupo, ele usa as vestes, condecorações e armas correspondentes ao seu posto e identidade. Reforça-se o posto que existe e que pode estar, em virtude das outras rotinas e sistema de posições, submerso. O chamado ritual de separação é justamente esse momento onde é destacado o papel de general e são inibidos todos os outros." (Da Matta, 1983: 61)

Se, na passagem acima, trocarmos o termo "general" por juiz, promotor ou defensor, poderemos chegar à conclusão de que, no momento em que esses entram em plenário, vestindo suas togas pretas, seus "postos" são reforçados, o que não fica tão evidente quando estão de terno e gravata, caminhando pelos corredores do Tribunal. Eles vivem, em plenário, um ritual de separação. Quanto aos jurados, no momento em que são sorteados, aceitos e ocupam seus lugares, reforçam-se como cidadãos "de respeito" e, provisoriamente, tornam-se juízes.

O reforço é, assim, uma escolha “(...) daquilo que está submerso (ou em vias de submergir), do que está dentro e, por isso mesmo, não está sendo devidamente percebido. Quando tal mecanismo é aplicado (...), cria-se um campo formal ou respeitoso (...). Separação ou reforço seriam assim o mecanismo básico de rituais freqüentemente chamados de formais (...)" (Da Matta, 1983: 62).

É bastante nítida, portanto, a diferença entre o "campo formal e respeitoso" do plenário, durante a sessão, e o "campo informal e até jocoso" da "sala de lanche" dos jurados, onde, nos intervalos das sessões, juntamente com o juiz, promotor e defensor, jurados costumam se reunir para descansar e comentar "assuntos não relacionados, direta ou mesmo indiretamente, ao caso em julgamento". Nas sessões em que tive a oportunidade de presenciar tais conversas, observei um clima de "descontração" — juiz servindo café aos jurados e vice-versa; jurados sentados, juiz e promotor em pé porém, sutilmente marcado por uma curiosidade recíproca e uma vontade de demonstrar o quanto, cada um, é bem informado e inteligente.

7 - GLUCKMAN, Max - "Les rites de passage" In Essays on the ritual of social relations. Manchester: Manchester University Press, 1962 
Numa dada sessão em que o plenário foi esvaziado para servir de sala secreta, logo após reabertas as portas, observei a seguinte conversa entre o juiz e um dos jurados:

$\Rightarrow$ Juiz: Isto aqui é um verdadeiro absurdo! - [climatização do Fórum - ar condicionado muito frio - e as conseqüências disso para a saúde de todos]. Circulam, diariamente, por este Fórum, mais de 400 réus que vêm das mais diferentes carceragens, com as mais diversas doenças.

$\Rightarrow$ Jurado: Vírus e bactérias transmissores de muitas dessas doenças passam de sala para sala através dos dutos do ar condicionado!

$\Rightarrow$ Juiz: Exatamente! Sem contar a fumaça de cigarros, pois em qualquer lugar do Fórum que se fume, essa fumaça entra nos dutos.

$\Rightarrow$ Jurado: Como ocorre nos aviões que, só pró-forma, separam fumantes de não fumantes...

$\Rightarrow$ Juiz: É... Não tem jeito. Ou melhor, se eu ficar doente, vou processar o Poder Judiciário.

Vários outros jurados também se manifestaram, demonstrando seus respectivos saberes técnicos, biológicos, médicos, etc e, assim, terminou o intervalo, antes de ser proclamada a sentença. Será que falar da tuberculose no sistema prisional não era, indiretamente, falar da situação de réus presos e condenados e, consequentemente, do destino do homem em julgamento que, aliás, foi condenado a 18 anos e 10 meses de reclusão em regime fechado? ${ }^{8}$

No $4^{\circ}$ Tribunal do Júri (Penha), em meu primeiro contato com o cotidiano dos que por lá trabalhavam, observei que a "sala secreta", quando não era usada para a votação dos quesitos, tornava-se local em que um escrevente tricotava, uma funcionária pintava as unhas, outra lia fotonovela e todos se encontravam para "papear". As relações entre juiz e funcionários também eram, aparentemente, muito igualitárias e até brincalhonas fora do ambiente "ritual" das sessões ${ }^{9}$.

Em suma e de acordo com Da Matta:

1. Os mesmos elementos que compõem os ritos - matéria prima - também compõem a vida cotidiana, mas nos ritos eles são manipulados de forma especial. Trata-se, portanto de uma diferença de grau e não de qualidade;

2. Os rituais salientam, focalizam e destacam aspectos, elementos e relações do mundo diário, sendo três os modos básicos disso se proceder: através de mecanismos de reforço, inversão e neutralização ou, em outras palavras, de comportamentos rituais que enfatizam o respeito, a jocosidade ou a evitação;

\footnotetext{
8 - 18/07/2001, das 9h30' às 12h, Plenário 9 do $1^{\circ}$ Tribunal do Júri (Barra Funda).

9 - entre agosto de 1988 e março de 1989, trabalhei na pesquisa "Justiça Criminal e Violência Urbana", coordenada pelo Prof. Dr. Sérgio Adorno - apoio financeiro da Fundação Ford. (Schritzmeyer, 1989: 10).
} 
3. Importa mais entender as relações básicas do mundo social que constituem os ritos, do que classificálos;

4. "Os rituais dizem as coisas tanto quanto as relações sociais. (...) no mundo ritual, as coisas são ditas com mais veemência, com maior coerência e com mais consciência. (...) permitem maior clareza às mensagens sociais." (Da Matta, 1983: 65)

5. os ritos, por um lado, ajudam a criar o tempo ${ }^{10}$ (Leach, 1974) e, por outro, engendram cortes nas rotinas sociais.

\section{- O tempo do e no Júri: um rito de passagem}

Os ritos de passagem marcam o desenvolvimento social do indivíduo, sendo os mais comuns, em todas as sociedades, os de nascimento, puberdade, casamento e morte. Neles, vestimentas, comida e comportamento costumam ser especiais.

Antes de mais nada, um julgamento pelo Júri, e mesmo outros tipos de julgamento criminal, representam marcas no desenvolvimento social do acusado. O simples fato de alguém ser indiciado - de seu nome constar, num boletim de ocorrência, como provável autor de um delito - e, mais ainda, de tornar-se réu e ir a julgamento, macula o que se espera social e legalmente desse desenvolvimento. O registro oficial dessa marca traduzse na folha de antecedentes criminais do réu que, nas sessões de Júri, normalmente, é utilizada, tanto pela acusação quanto pela defesa, obviamente para fins opostos ${ }^{11}$. Mas, seja como for, durante o tempo do julgamento, a vida do(a) acusado(a) é resumida e reapresentada, a partir de marcas criminais ou da ausência delas.

Se o réu ou ré possui registros de passagens anteriores pela polícia, antecedentes criminais ou mesmo provas testemunhais de que seu comportamento é "condenável", isso Ihe será desfavorável e, normalmente, ocupará boa parte do discurso da acusação.

Como bem analisou Mariza Corrêa (1983), réus que não são "trabalhadores", "bons pais de família" ou jovens, solteiros e honestos - não levam dinheiro para casa, são agressivos com parentes e ains, têm várias mulheres e/ou filhos com mais de uma delas, ou são homossexuais, consomem álcool e outras drogas, não têm emprego fixo etc - ficam mais vulneráveis aos ataques da acusação, pois o desenrolar de suas vidas é enfatizado a partir desses aspectos, de modo que o comportamento criminal surge,

\footnotetext{
$\overline{10}$ - este aspecto será aprofundado no último capítulo, mas algumas menções iniciais já serão adiantadas no item que se segue.

11 - Embora, na teoria, não devam pesar contra um réu processos anteriormente arquivados ou em que ele foi inocentado, ou aqueles referentes a ocorrências que precederam sua maioridade penal (Delmanto, 1988: 97), na prática, isto pode ser direta ou indiretamente mencionado e contar em seu desfavor.
} 
"naturalmente", como conseqüência do mau comportamento social. Rés que, por sua vez, segundo testemunhas ou registros policiais e judiciais, não correspondem à figura de "boa esposa" e "boa mãe", ou mesmo de "mulher honesta", também têm, no Júri, através do discurso do promotor, o resumo de suas vidas pautado por essas características. Nesses casos, normalmente, os defensores tentam mostrar outros aspectos considerados "positivos" das vidas de seus clientes, mas raramente, combatem a "negatividade" atribuída pela acusação a certos estereótipos.

A manipulação dessas marcas sociais é que está em jogo em qualquer julgamento e, especialmente, nas sessões de Júri, pois é ela que permite aos arguidores caracterizar réus, resumindo, em algumas horas, anos e modos de vida que justificarão passagens da liberdade ao aprisionamento ou vice-versa.

Lênio Luiz Streck é um dos poucos procuradores de Justiça e professores de Direito - Rio Grande do Sul — que, remetendo-se a uma ampla bibliografia sócioantropológica para estudar o procedimento do Júri, sugere pensá-lo como um rito de passagem que se consuma na sentença, a qual ou agrega o réu à sociedade ou dela 0 desagrega (Streck, 1998: 90).

Voltemos à construção do tempo. "O que há de mais singular a respeito do tempo é certamente que tenhamos, de algum modo, tal conceito. Experimentamos o tempo, mas não com os nossos próprios sentidos. Nós não o vemos, nem o tocamos, nem o cheiramos, nem o degustamos, nem o ouvimos. Como, então? De três modos: Em primeiro lugar, nós reconhecemos a repetição. (...). Em segundo lugar, nós reconhecemos, ao envelhecer, a entropia. (...). Nossa terceira experiência de tempo diz respeito à velocidade com a qual o tempo passa. (...)" (204). Portanto, "(...) a regularidade do tempo (...) é uma noção fabricada pelo homem, que nós projetamos em nosso ambiente para os nossos próprios objetivos particulares." (Leach, 1974: 205).

Nos julgamentos pelo Júri, há uma reconstrução do tempo das vidas dos réus. Elas são reelaboradas a partir da constatação de se houve ou não repetição de comportamentos social e legalmente recrimináveis. Se, com o passar dos anos, os réus repetiram atitudes consideradas socialmente "positivas" - trabalharam, honestamente, criaram seus filhos e ajudaram sua família, dando-Ihes alimento, estudo, saúde, moradia etc - a ocorrência criminal de que são acusados é percebida como uma exceção de cuja autoria se deve desconfiar. Do contrário, se suas vidas revelam um acúmulo de "más condutas sociais" a acusação criminal em julgamento se torna quase que uma decorrência esperada. 
Prossegue Leach, em sua análise sobre a representação simbólica do tempo, afirmando que "(...) os ritos de passagem, (...) devem, claramente, estar ligados com alguma espécie de representação ou conceptualização do tempo. (...), um grande número de povos considera o tempo como indo para trás e para a frente. Com uma visão pendular do tempo, a seqüência das coisas é descontínua; o tempo é uma sucessão de alternações e paradas. (...). E nossas experiências mais elementares do fluxo de tempo são, certamente, desta espécie: dia-noite dia-noite, quente-frio quente-frio, molhado-seco molhado-seco. (...); a essência do assunto não é o pêndulo, mas a alternação" (1974: 206).

É exatamente essa concepção de um tempo marcado por uma sucessão de alternações e paradas - sucessão de "bons" ou de "maus" comportamentos dos réus em suas vidas cotidianas - que orienta o modo como promotores e defensores apresentamnos aos jurados. Quanto mais longos os intervalos entre um "mau" comportamento e outro, melhor para a defesa. Quanto mais constantes e repetitivas as atitudes consideradas socialmente reprováveis, melhor para a acusação. Essa é a lógica da construção do tempo das vidas de réus no Júri e disso dependerá o desfecho dos julgamentos, pois, muito provavelmente, é também assim que jurados compreendem o passar do tempo de suas próprias vidas.

\section{- Efeito dramático}

Todo ritual é um dromenon, uma ação cuja matéria é um drama, um ato representado num palco. Essa ação, segundo Huizinga, pode ter a forma de um espetáculo ou de uma competição, sendo o sentido de representação, no ritual, o da identificação de uma (...) "repetição mística ou (...) reapresentação do acontecimento. O ritual produz um efeito que, mais do que figurativamente mostrado, é realmente reproduzido na ação. Portanto, a função do rito está longe de ser simplesmente imitativa, leva a uma verdadeira participação no próprio ato sagrado (...). O que é importante para a ciência da cultura é procurar compreender o significado dessas figurações no espírito dos (...) que as praticam e nelas crêem." (Huizinga, 1980:18 - grifos do autor).

Ritual, drama e, consequentemente, teatralidade - conceitos que estruturam esta tese, estão, assim, teórica e intrinsecamente relacionados. Se a função do rito é levar a "uma verdadeira participação no próprio ato sagrado", podemos afirmar que a função do Júri é levar a uma verdadeira participação no jogo sócio-estatal de legitimar a produção de motivações legítimas e ilegítimas para matar.

No ritual do Júri temos uma ação cuja matéria é o drama de julgar em que circunstâncias a morte de um ser humano por outro é mais ou é menos legítima e até 
legal e, portanto, passível de absolvição do agente, ou condenável. Dependendo desse julgamento, advém a decisão de se o acusado deve ter seu poder de matar controlado pelo Estado - permanecendo confinado e separado "da sociedade" — ou se ele tem condições de se auto-controlar e, assim, viver em liberdade.

Esta é a questão dramática presente no ritual do Júri e que aprofundaremos no próximo capítulo.

\section{- Efeito "sacralizante"}

Numa das cenas finais da peça de Ariano Suassuna "O auto da compadecida", tem-se um julgamento divino. Homens e mulheres que morreram comparecem diante de Jesus Cristo, representado por um homem forte e negro, que decidirá se eles irão para o inferno, para o purgatório ou para o céu. Antes de começar o julgamento, os recémchegados sentem medo, pois a porta do inferno se entreabre e eles vislumbram um de seus possíveis destinos. Quando o julgamento se inicia, o demônio se apresenta como acusador. A defensora, Nossa Senhora, mãe de Jesus, só aparece depois, quando sua intervenção se faz necessária para melhor orientar a decisão de seu filho-juiz. Diferentemente do que ocorre num julgamento pelo Júri, não há jurados e os réus argumentam, vez por outra, em favor próprio. O acusador, por sua vez, além de enumerar os pecados dos réus, expressa, ao filho de Deus, sua preocupação com um possível descrédito da "instituição divina", caso as absolvições se tornem regra. Nesse momento, Jesus-juiz, Nossa Senhora-defensora e o demônio-acusador se colocam como partes de um mesmo sistema que só faz sentido enquanto conjunto.

O Veredicto divino para um dos protagonistas do filme - um homem pobre e franzino, que usava de sua astúcia, acima da média, para tirar proveito das situações foi o de que ele ressuscitaria e voltaria para o "mundo dos homens", onde teria nova oportunidade para rever suas atitudes e comportamento. Assim, ele ressuscita, pouco antes de ser enterrado e, dias depois, um negro cruza seu caminho e the pede um pouco da exígua comida de que dispunha. Ele despreza o homem, por ser negro, homem esse que é Jesus-juiz.

Ao final de uma das sessões que etnografei ${ }^{12}$, não pude evitar a lembrança desse filme. O réu - no caso, negro, jovem e forte - era acusado de ter cometido dois crimes, um homicídio simples consumado e uma tentativa de homicídio simples, contra dois

12 - 05/09/2001, 17h22', Plenário 9 do $1^{\circ}$ Tribunal do Júri (Barra Funda). Sessão registrada, na íntegra, no capítulo 5 . 
irmãos que perseguiam familiares seus. Os defensores eram uma advogada de meiaidade e seu jovem filho, ambos brancos. Além de ela passar a imagem de uma típica mãe de classemédia, "dona-de-casa esclarecida", a própria mãe do réu estava na assistência, acompanhada por três mulheres jovens, todas negras, uma delas irmã e outra mulher do réu. Essa presença feminina em torno do réu, não passou desapercebida perante os jurados, o juiz, o promotor e os demais assistentes, embora não seja possível afirmar de que maneira ou maneiras ela os impressionou, pois não entrevistei a todos, após a sessão. $O$ fato é que, quando a advogada-mãe estava com a palavra, a atenção que jurados e demais presentes lhe dirigiam parecia maior do que quando o advogado-filho se colocava. E as quatro mulheres da platéia, visivelmente sofridas, ansiosas e preocupadas com o réu, também eram constantemente observadas pelos operadores técnicos e jurados. Elas prestavam atenção nas cenas do julgamento, mas com olhares perdidos, de quem ali estava somente com o corpo, mas não com as idéias e lembranças.

Enfim, no momento em que o juiz se levantou para anunciar a sentença, e que todos puseram-se em pé, a advogada-mãe e a própria mãe do réu tinham expressões bastante semelhantes: olhavam-no com expectativa e esperança. Quando o juiz comunicou a absolvição do réu, nos dois crimes de que era acusado, a advogada-mãe abraçou o advogado-filho e ambos cumprimentaram o réu, ao mesmo tempo que a mãe e as outras mulheres da família do réu, também abraçadas, choravam. Especialmente a mãe, do fundo do plenário, com as mãos postas, exclamava em voz alta: "Foi Deus quem salvou meu filho. De novo, foi Deus! É Deus quem protege meu filho. É por causa de Deus que ele está vivo! Obrigada, Senhor, por iluminar esse juiz! Obrigada, Senhor juiz!" Aproximei-me delas, para ouvir melhor o que diziam, entre si:

$\Rightarrow$ Mãe: Eu sabia que Deus faria Justiça.

$\Rightarrow$ Irmã : Ele já sofreu tanto...

$\Rightarrow$ Mulher: Se tinha de pagar seus pecados, já pagou!

$\Rightarrow$ Mãe: Ainda bem que Deus iluminou essa gente aqui. Deus seja louvado e abençoe a todos! $\Rightarrow$

Essa identificação entre as mães e as demais mulheres da família do réu é o significante-chave desse julgamento, pois foram a maternidade e a feminilidade que salvaram o réu, como foi Nossa Senhora quem salvou o rapaz franzino na peça de Suassuna. As mulheres desse julgamento, por estarem envolvidas, tanto no contexto do crime - enquanto vítimas, mas também protetoras - quanto no contexto do julgamento - enquanto assistentes - indicaram ao juiz e aos jurados a bondade do réu e sua capacidade de redenção, sem contar que o argumento-chave da defesa foi o de que o réu agira em defesa da integridade de sua família. É possível que, graças ao apoio do mundo 
feminino do amor e do sentimento, esse réu tenha escapado do mundo masculino e frio da lei e da carceragem.

Eu poderia ter, imediatamente, entrevistado essas mulheres, mas não consegui. Senti que invadiria demais suas privacidades. A mulher do réu foi ao encontro dele e dos advogados; as duas outras jovens acompanharam a senhora até o banheiro. Quando saíram de lá, uma delas afastou-se para telefonar. Todas continuavam chorando. Somente depois de passados talvez 15 minutos do anúncio da sentença, aproximei-me da mãe do réu e perguntei-Ihe: "Se ele tivesse sido condenado, o que a senhora acharia?" Sem titubear, olhando-me bem nos olhos, ela disse: "Se Deus fizesse isso é porque meu filho não taria pronto ainda prá continuar do lado de cá, com a gente, e nem a gente com ele. Deus decidiu que nós vai ficá junto agora, como poderia tê decidido que nós ia ficá separado. É Deus quem decide, filha. Nóis tudo tamo aqui prá cumpri pena, porque não é só quem tá preso que cumpre pena, não."

Essa sessão marcou-me por vários fatores, mas, especialmente, porque, no que tange ao ritual, se considerarmos o conjunto dos participantes como formado não só por operadores técnicos, mas também por jurados, réus e assistentes, podemos concluir que, ao mesmo tempo, eles não participaram de igual maneira da sessão, mas comungaram de algo que os assemelhou. Se é correto afirmar que há tantas diferentes inserções num ritual quantas são as diferenças sócio-culturais entre seus participantes, igualmente correto é concluir que é tão mais intenso um ritual quanto, apesar das grandes diferenças sócio-culturais entre seus participantes, ocorre uma troca de mensagens entre eles, através de um fluxo comum de linguagem.

Enquanto, provavelmente, para jurados e operadores do direito - imersos num imaginário de classe média, que, alías, impregna a literatura jurídica — as regras legaisracionais do Júri produzem Justiça, para muitos dos réus e de seus parentes, é provável que tais regras sejam traduções humanas da vontade divina e só façam sentido enquanto tais. Contudo, tanto para uns quanto para outros, na sessão relatada, houve uma confluência de significados em torno da presença das "mulheres do réu". Elas permitiram o contato e o consenso entre diferentes significantes sócio-culturais.

Isso tornou, conforme apontamos, parágrafos atrás, a simplicidade material do plenário, um lugar quase sagrado. O rito, com sua força - com a força das interações produzidas por seus participantes - impôs solenidade àqueles momentos. Fizeram-se claros os limites do círculo mágico. 


\section{- Efeito totalizador?}

"O rito (...) pode marcar aquele instante privilegiado onde buscamos transformar o único no universal (...); o regional no nacional (...); o individual no coletivo (...). É (...) nesse jogo de transformação que uma sociedade se revela enquanto coletividade diferenciada; (...). Abundam (...) na sociedade complexa, os rituais nacionais que ajudam a construir, vivenciar e perceber 0 universo social, freqüentemente fragmentado por contradições internas, como uma totalidade. (...), nos sistemas tribais, ocorre justamente o oposto. (...), os ritos são em geral momentos individualizadores, voltados para a resolução de crises de vida (...), o grupo impede o processo de livre individualização, criando as condições para que tudo fique novamente junto" (Da Matta, 1983: 25-26).

Apesar de todas as sessões de julgamento em que se baseiam as análises desta tese terem ocorrido numa sociedade complexa, poderíamos pensar que, de um certo modo, elas tanto caracterizam-se pela construção, vivência e percepção do universo social como uma totalidade - réus, jurados, defensores e promotores são concebidos como integrantes de uma mesma "sociedade", ainda que fragmentada por contradições internas - , quanto pelo que marca os rituais das sociedades tradicionais — resolução de um caso específico de "desvio" das regras.

"O ritual (...) é, entre outras coisas, um instrum ento privilegiado para expressar e enfeixar totalidades. (...) é o ritual que consagra tais globalizações que já existem na re alidade". (idem: 27).

Os detalhes dos julgamentos tanto destacam normas morais, sociais e ideais de relação social quanto evidenciam a realidade fragmentada e conflituosa da aplicação cotidiana dessas. Em outras palavras, o ritual do Júri consagra regras e valores genéricos interiorizados nos sujeitos e não claras para eles, apontando para "exceções". Quando situações concretas permitem a todos materializar essas globalizações, as exceções fazem sentido e são também englobadas. Isso parece ocorrer no Júri. 


\section{\III}

"Por que utilizamos uma forma tão complexa quanto dispendiosa como o ritual para legitimar coisas e relações já sabidas, (...)?” (Da Matta, 1983: 27). Para responder a essa pergunta, podemos lembrar e criticar as explicações funcionalistas de Malinowski ${ }^{13}$, segundo as quais as instituições, normas, ritos e mitos são modos de responder a necessidades básicas e primárias, forçando o grupo na direção de invenções culturais. A crítica fundamenta-se no argumento de que tais explicações não dão conta de por que são diversas as soluções culturais dadas às mesmas necessidades básicas e primárias (idem: 28).

Por que julgar homicídios através de Tribunais do Júri? É complexo e economicamente muito dispendioso, segundo alguns.

Sem dúvida, há várias outras possibilidades rituais de julgar homicídios, mas o rito pelo Júri, enquanto instrumento que possibilita respostas humanas diferenciadas e não mecânicas à necessidade social de julgar e legitimar ou não mortes violentas, é um ritual especialmente dramatizado e que, por essa razão, permite a seus participantes uma forte percepção de si mesmos, do grupo com que compartilham seus principais valores e das múltiplas possibilidades de reinventá-los.

Considerando que é banal afirmarmos que o Júri é uma arena de lutas e um lugar de dominação no qual se realiza a sujeição de certos membros da sociedade, cabe então revertermos esse pensamento e avançarmos na compreensão desse ritual como construtor de subjetividades e experiências sociais que podem definir e redefinir o que é cidadania, gênero, valores familiares etc. Eis o que constitui a matéria-prima desta tese, dos próximos capítulos e, muito provavelmente, de desdobramentos que pretendo dar a este trabalho.

\section{而}

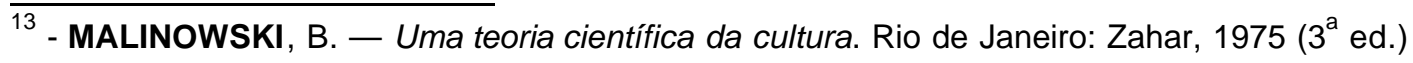




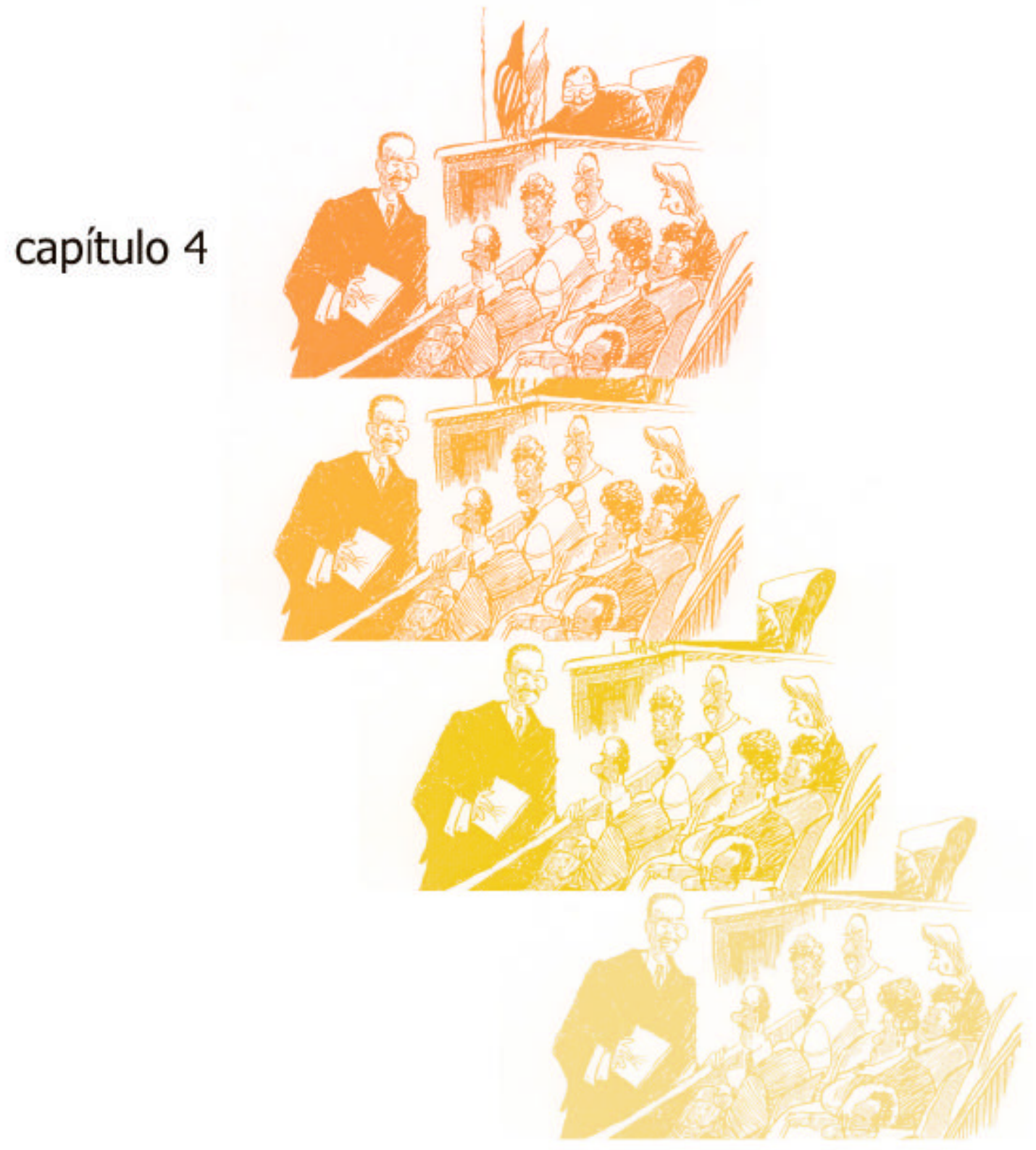




\section{JÚRI-TEATRO}

\section{- Introdução}

Neste capítulo, com inspiração em idéias de Georges Balandier, a dinâmica das sessões cotidianas de julgamento pelos Tribunais paulistanos do Júri é tratada como um exercício dramatizado de poder. Estão em discussão as características desse exercício e desse poder - o que é dramatizado, que tipo de dramatização mais se observa e por que a teatralidade é intrínseca a esse cerimonial judiciário.

A lógica em que estão calcadas as sessões - já analisada nos capítulos 1 e 2 é retomada para permitir a descrição e análise do funcionamento teatral do Júri - " "...) sua encenação, cenário, papéis, instâncias secretas e violências, revelações e efeitos de surpresa" (Balandier, 1982:10) - e para que se possa interpretá-lo como provocador de emoções como a compaixão, o ódio, a pena, a indignação e o sentimento de pertencer ou não a um grupo.

Partindo do pressuposto de que os julgamentos pelo Júri podem conduzir os réus a mortes morais, refletiremos sobre as circunstâncias em que essas mortes se processam e quais valores sociais são por elas salvaguardados.

\section{- Uma "sociologia dramatizada" ou uma "dramatização sociologizada"}

Os "palcos" do Júri são espaços sociais em que, mais visivelmente do que em outros, observa-se a força da teatrocracia, ou seja, de um "(...) regime permanente que se impõe aos diversos regimes políticos, revogáveis, sucessivos". Segundo alguns, essa forma teatral de regular a vida cotidiana dos homens em sociedade é tão poderosa e onipresente que pode ser encontrada "Por trás de todas as formas de arranjo da sociedade $e$ de organização dos poderes"(Balandier, 1982: 5).

Teatrocracia é um conceito relativamente recente - século XIX - e foi criado por Nicolau Evreinov ${ }^{1}$. Ele sugeria a montagem de “(..) um tribunal teatral para todas as manifestações da existência social, notadamente as do poder" (idem). A idéia do mundo como um palco, contudo, é bem anterior a esse conceito; remonta, pelo menos, ao início do século XVII, na Europa, quando do surgimento do grande teatro laico. Nas principais peças de Shakespeare, há um “(...) comentário dramático das formas em que as práticas

1 - "(...) russo de múltiplos talentos e atividades, mas desconhecido - exceto de Beckett que recebeu sua influência ao estabelecer o teatro da zombaria". (Balandier, idem) 
coletivas se revelam. (...) Um jogo encenado a fim de mostrar os jogos da sociedade,(...); uma sociologia que não depende de enunciação, mas da demonstração pelo drama." (Balandier, 1982: 5). Todavia, a estreita ligação conceitual entre encenação, tribunal, drama e jogo ingressou no corpo teórico e empírico das ciências sociais somente nas primeiras décadas do século XX (Huizinga, 1980:7).

Partindo dessa estreita ligação conceitual, é possível constatarmos que a maior parte das narrativas de promotores e defensores do Júri está baseada num discurso de "caráter dramático-sociológico", pois embasa-o uma certa lógica classificatória e analítica da organização e do funcionamento da vida social. Contudo, apesar de (socio)lógicas, essas narrativas são especialmente fortes devido a sua forma dramática de expressão e em razão dos sentimentos que articulam e expõem.

Ao longo de sustentações orais, réplicas e tréplicas, ou seja, "em ato", modelos de conduta social são articulados, apresentados, exemplificados e reiterados a partir de peculiaridades do "elenco", do "cenário" e da trama de cada Júri. Em cada sessão, juízes, promotores, defensores, jurados, réus, testemunhas, funcionários e assistentes elaboram percepções, uns a respeito dos outros, valendo-se de uma linguagem baseada em estereótipos que ali se atualizam ao serem aplicados. Em outras palavras, essa troca e elaboração de informações, predominantemente não verbal, lida com interpretações silenciosas e recíprocas de aparências, ou seja, com a combinação e atribuição de significados a variáveis como sexo, idade, etnia, compleição física, modo de se vestir, timbre e entonação de voz, gestualidade e modo de olhar.

Um defensor deixou isso evidente, durante uma entrevista ${ }^{2}$ :

$\Rightarrow$ Eu: O Sr. costuma ter suas defesas prontas e desenvolvê-las em plenário, independentemente de quem são os jurados, ou o Sr. faz algum tipo de adequação entre o que preparou para argumentar e as aparências dos jurados que são, de fato, sorteados?

$\Rightarrow$ Defensor: Quando não consigo perceber bem quem são os jurados, quando eu os acho pouco transparentes, meu desafio aumenta, pois tenho que me dirigir a eles através de idéias que não sei se causarão impacto. É claro que, mais ou menos, a gente sabe o que causa impacto no cidadão de classe média, no homem comum, na dona-de-casa, na jovem estagiária, nos profissionais liberais.

$\Rightarrow$ Eu: $E$ o que é que causa impacto?

$\Rightarrow$ Defensor: É o que a maioria das pessoas comenta em festas, em bares, e que espera dos políticos... É disso que eu parto para mostrar o réu como um inocente ou mesmo como um culpado, mas que não é nenhum monstro. Alguns jurados discordam, mas a maioria leva em conta esses argumentos, pois seriam os deles.

$\Rightarrow \mathrm{Eu}: E$ o que, exatamente, o Sr. comenta no Júri e também é comentado pela maioria das pessoas em festas e bares?

\footnotetext{
2 - Entrevista concedida em 19/06/1997, na sala do $5^{\circ}$ Ofício do Tribunal do Júri (Pinheiros).
} 
$\Rightarrow$ Defensor: Ah! Essas coisas que basta qualquer um de nós ligar a TV e ouvir. (...) Eles acham que qualquer jovem favelado, especialmente se for mulato ou preto, é traficante, ladrão e anda armado. Contudo, eles também sabem que a polícia tortura, é corrupta, persegue. (...) os jurados podem ter pena ou medo [dos réus com o perfil citado]. Eu exploro o que Ihes dá pena.

$\Rightarrow$ Eu: Na sua opinião, os promotores exploram o que causa medo nos jurados?

$\Rightarrow$ Defensor: Sem dúvida! $O$ que eles fazem, geralmente, é reiterar preconceitos, enquanto eu tenho que fazer os jurados pensarem nas pessoas honestas e pobres que eles conhecem; na vida dura que elas levam (...).

Esse advogado, cujo depoimento representa, em grande parte, o que outros operadores técnicos declararam em suas entrevistas, aponta um modelo básico de sociedade com que se trabalha no Júri, o qual é constantemente adequado e aplicado, a cada caso concreto, no "calor" dos julgamentos. Esse modelo delineia quem são os jurados típicos - cidadãos de classe média, homem comum, dona-de-casa, jovem estagiária, profissionais liberais - e qual seu "senso comum de classe média" - "(...) o que a maioria das pessoas comenta em festas, em bares, e que espera dos políticos, (...) que qualquer jovem favelado, especialmente se for mulato ou preto, é traficante, ladrão e anda armado. Contudo, eles também sabem que a polícia tortura, é corrupta, persegue. (...)". Conclusão: os valores desse "senso comum" devem ser explorados a favor ou contra os réus, dependendo da persuasão a ser desenvolvida e dos estigmas a serem reiterados ou combatidos.

Essa "sociologia selvagem" dos plenários ${ }^{3}$ está na base da teatrocracia do Júri, muito mais do que qualquer regra prescrita nos códigos legais. Ela complementa e preenche com exemplos e argumentos o script legal das sessões, permitindo aos defensores, promotores e jurados travarem um "diálogo" dramático, ininterrupto, tenso e denso.

Um jurado, certa vez, declarou-me: "A gente percebe quando eles falam certas coisas prá impressionar. Não é tanto o que eles falam, mas o jeito de falar. Têm uns que são meio paradões e cansam a gente. Têm outros que até incomodam de tanto que andam, gesticulam. (...) Sei lá... Só alguns acertam no ponto: falam de um jeito que a gente entende, (...). Parece até que adivinham o que a gente tá pensando. ${ }^{\sharp 4}$

\footnotetext{
3 - Alguns chamam de "psicanálise selvagem" às tentativas de interpretações psicanalíticas por parte de leigos e mesmo de profissionais, fora do contexto psicanalítico e, portanto, sem respeito a certos preceitos teóricos, metodológicos e éticos que orientam a prática da psicanálise. Entendo que algo semelhante ocorre com a sociologia quando utilizada por leigos e mesmo por profissionais de outras áreas, em contextos não acadêmicos, para legitimar opiniões sem a devida referência a - e talvez, sem a consciência de - limites teóricos e metodológicos de certos conceitos e modelos.

4 - Entrevista concedida em 22/02/1999, num dos corredores do $1^{\circ}$ Tribunal do Júri (Vila Mariana), pelo Sr. Adilson, 37 anos, técnico em informática.
} 
Provavelmente, para esse jurado, "paradões" e "cansativos" são promotores e advogados cujos desempenhos dramáticos não atingem, eficazmente, seu universo de valores. Quando alguns "acertam no ponto", isso deve significar que, em cena, no transcorrer do drama, estabeleceu-se uma sintonia fina e significados foram compartilhados.

Quanto ao conceito de drama, vale lembrar que sua origem grega guarda um duplo sentido: "o de agir e o de representar o que está em movimento a fim de provocar a descoberta das verdades escondidas em todos os assuntos humanos." (Balandier, 1982: 5).

Conforme apontamos, no final do capítulo anterior, um dos traços distintivos de rituais, em geral, e do Júri, em particular, é justamente a dramatização nesse duplo sentido de ação e de representação, pois ações, que no mundo diário são banais e triviais, adquirem significados especiais quando representadas nos plenários do Júri. Ao transformarem-se em representações significativas, elas geram a sensação de que mistérios e complexidades de crimes, acusados, vidas e mortes são passíveis de revelação, organização e julgamento. A diversidade humana é, assim, constatada, classificada e julgada. Ser homem ou mulher; hétero, homo ou bissexual; casado, amasiado ou solteiro; ter ou não filhos; ser jovem, maduro ou idoso; falar um português correto ou sofrível, usar roupas novas ou surradas, ficar cabisbaixo ou altivo, ter voz grave ou aguda, tudo passa a ter algum significado social. Sinais individuais são interpretados como reveladores de características das relações humanas.

No espaço cênico do Júri, como bem apontou o advogado entrevistado, as mesmas coisas ditas em festas, bares e programas de TV são representadas e reapresentadas, ganhando um status pseudo-técnico-científico, de modo que cada sessão, ao mesmo tempo que exemplifica e legitima essas pseudo-teorias, também explicita um certo senso comum sobre a criminalidade e o funcionamento social.

Outro aspecto relevante da dramaturgia do Júri é o de que, nesse tipo de tribunal, teoria e teatro estão especialmente entrelaçados. Como na "(...) cidade grega antiga, os grandes mitos e o teatro que os apresenta estão em correspondência. Esses, pelo jogo dos personagens reveladores, (...) tornam aparentes os princípios que governam a vida coletiva, os debates e conflitos que engendra." (Balandier, 1980: 5).

Levando em conta essa perspectiva, nos tribunais paulistanos do Júri, réus, vítimas e testemunhas podem ser vistos como espécies de "personagens reveladores", pois as histórias que se contam sobre eles, em plenário, tornam perceptíveis diversos princípios, por vezes conflitantes, que governam a vida na cidade. 
Especificamente os réus, desse ponto de vista, são "reveladores", pois, apesar de permanecerem a maior parte do tempo calados, sentados num canto, ouvindo o que se fala a respeito deles, ali estão como encarnações das narrativas de acusadores e defensores. Tais narrativas permitem a expressão, ainda que imaginada, de princípios que governam a vida das chamadas "classe média" e "população de periferia" da cidade de São Paulo. Especialmente um dos princípios máximos que a lei prevê como universal — "não matar" - , a prática do Júri apresenta e reitera como dependente de um feixe de circunstâncias e interpretações sociais, pois matar pode ou não ser legítimo, dependendo de como se narra a morte ocorrida e se descrevem os personagens envolvidos.

Conforme o perfil sócio-econômico de quem morre e de quem mata, bem como das razões alegadas para a ocorrência das mortes, essas e seus protagonistas são julgados. Portanto, homicídios narrados em plenário levam a julgamento, mais do que a morte, os adjetivos que a acompanham e que qualificam os vivos e os mortos em questão - e até mesmo outros vivos e outros mortos por esses representados.

Jurados, por sua vez, através dos dramas que lhes são narrados, teorizam em que circunstâncias devem legitimar ou não as mortes. Ao votarem "sim" ou "não" aos quesitos - que tanto contemplam a possibilidade de absolvição a condenação do réu quanto verificam atenuantes e agravantes do crime - elaboram e objetivam temas difusos e complexos do cotidiano da cidade e de suas vidas, como monogamia, obrigações decorrentes de parentesco e conflitos entre grupos. Votar permite-lhes elaborar uma imagem lacônica desses e de outros temas e até mesmo de conceitos abstratos como os de sociedade, cultura e criminalidade. Eis um trecho de uma entrevista que exemplifica essa "teorização" da vida social por um jurado ${ }^{5}$ :

"Eu acho a maior parte das histórias [narradas sobre réus e vítimas] muito diferentes do tipo de vida que eu levo, mas, de vez em quando, até penso na minha própria vida. Houve um caso, há alguns meses, de um irmão que matou outro por causa de trapaças num negócio que eles tinham; e ainda diziam que a mulher do que matou era cantada pelo outro. (...). Entendo, perfeitamente, como é complicada essa coisa de ter sociedade com irmão e ch mulher da gente dar uma de quem gosta dos dois. É fácil perder a cabeça. Aliás, na vida, é fácil a gente perder a cabeça quando estão em jogo mulher e trabalho. Acho que isso independe da pessoa ser rica ou pobre, branca ou negra. É social, sabe? Quer dizer, todo mundo é meio igual em certas coisas: ciúmes, vontade de ganhar dinheiro fácil (...). É a vida!"

Em poucas frases, valendo-se de um dos casos em que atuou, esse jurado falou muito de si e de como interpreta alguns "dramas da vida". Embora, inicialmente, tenha 
diferenciado "seu tipo de vida" da maior parte das histórias que vão a Júri, terminou por concluir que "certas coisas" são universais - "independe da pessoa ser rica ou pobre, branca ou negra". De quebra, deixou escapar um certo machismo, pois, primeiro, mencionou que a mulher do réu seria cantada pelo cunhado-vítima mas, depois, colocou-a no papel de quem "cantava" ao invés de "ser cantada":.(...) complicada essa coisa de ter sociedade com irmão e da mulher da gente dar uma de quem gosta dos dois". Por fim, elege questões de parentesco, amorosas e profissionais - sociedade com irmão, mulher e trabalho - como dramas que fazem qualquer um "perder a cabeça". De modo aparentemente despretensioso, esse jurado elaborou uma reflexão bastante pretensiosa a respeito da vida.

\section{- Poder e drama}

Antes de detalharmos e exemplificarmos outras narrativas que dão substância aos julgamentos, convém explorarmos um pouco mais a íntima relação teórica entre a arte do governo e a da cena.

Foi Maquiavel um dos primeiros a propor imagens que identificavam o príncipe ao demiurgo e ao herói e a afirmar que as técnicas dramáticas deveriam ser utilizadas não só no teatro, mas na direção da cidade. Ao príncipe, segundo ele, caberia comportar-se como ator político para conquistar e conservar o poder. Sua imagem e aparência deveriam corresponder ao que seus súditos esperavam, não sendo prudente, portanto, governar mostrando desnudos o poder, a si próprio e a sociedade. Estava lançada a idéia de que a aceitação de um governante resulta, em grande parte, de sua capacidade de dramatizar, seja o poder, seja seu modo de exercê-lo, seja a própria vida social (Maquiavel, 1997).

Nesse sentido, também afirma Balandier: "Todo sistema de poder é um dispositivo destinado a produzir efeitos, entre os quais os que se comparam às ilusões criadas pelas ilusões do teatro" (Balandier, 1982: 6).

Se considerarmos o sistema de justiça criminal e, em seu interior o Júri, como sistemas de poder e, portanto, dispositivos destinados a produzir efeitos, cabe, então, identificarmos e analisarmos quais de seus efeitos comparam-se a ilusões típicas da arte teatral e o que o Júri governa através deles.

Por tudo que já foi apresentado, é possível afirmarmos que os efeitos tipicamente teatrais do Júri voltam-se, especialmente, à produção e ao controle da legitimidade do

5 - Entrevista concedida em 17/09/1999, por telefone, pelo Sr. Coreolano, 49 anos, comerciante. 
poder de matar. Toda a construção dos processos criminais — dos boletins de ocorrência às sentenças -, e especialmente o que se processa no cenário dos Júris é, antes de mais nada, uma tentativa do sistema de justiça criminal de, através de seus representantes - juízes, promotores, defensores e funcionários -, constituir-se como a instância mais legítima da produção e aplicação de regras para julgar o poder de matar.

Mesmo em se tratando de outros crimes, que vão a julgamento em palcos judiciais distintos dos plenários do Júri, a montagem social de suas narrativas - tanto das formais, que restam "filtradas" e registradas nos processos, quanto das informais, que se pode acompanhar em audiências - orienta-se bastante para a sacralização do monopólio do sistema de justiça estatal enquanto legítimo regulador de comportamentos. ${ }^{6}$

Provavelmente, não é por acaso que alguns parentes de réus, conforme já mencionamos no capítulo anterior, compararam juízes a Deus ou ao Criador; promotores a demônios; defensores a anjos da guarda ou a "padrinhos" dos réus e, finalmente, jurados a conselheiros de Deus ou mesmo a "santos". Eis um trecho da entrevista mais significativa, nesse sentido, pois nela todas essas comparações foram explicitadas ${ }^{7}$ :

$\Rightarrow$ Eu: O que a Sra. achou da maneira do juiz fazer perguntas ao seu filho?

$\Rightarrow$ Ela: Apesar dele ser novinho, parecia o Criador, sentado lá na frente, no meio, no alto, pensativo, com aquela roupa grande, aquela voz forte. Todo mundo sabe que Deus é de poucas palavras, meio bravo, mas que é bom. (...)

$\Rightarrow \mathrm{Eu}$ : $E$ o que a Sra. achou do promotor, do jeito dele acusar seu filho?

$\Rightarrow$ Ela: Eu acho que ele falou demais; ficou fazendo os jurados acharem que meu filho não presta. (...) Só um demônio sabe tão bem como é outro. (...)

$\Rightarrow \mathrm{Eu}$ : $E$ o advogado que defende seu filho, a Sra acha que ele...

$\Rightarrow$ Ela: Coitado... esse não tem muita chance num mundo como o nosso, pois ninguém quer ver o lado bom das pessoas. (...) mesmo as que erram têm lado bom. Acho que o anjo da guarda do meu filho tentou falar através desse doutor.

$\Rightarrow \mathrm{Eu}$ [nessa altura, induzi a entrevistada a concluir a comparação que, espontaneamente, iniciara] : Já que a Sra comparou o juiz ao Criador, o promotor ao demônio e o doutor advogado ao anjo da guarda de seu filho, com quem a Sra compararia os jurados?

$\Rightarrow$ Ela: Sei lá quem são essas pessoas, mas parece gente boa, honesta, que deixou de trabalhar prá estar aqui, ajudando. Acho que eles vão pensar bem em tudo, prá ajudar (...). Os santos fazem isso, né? Eles são quase como nós, são gente, mas foram

\footnotetext{
6 - Algumas recentes pesquisas sócio-jurídicas analisam a complexa transformação de narrativas de vítimas e testemunhas em queixas, dessas em inquéritos policiais e desses em denúncias e finalmente em processos, com seus respectivos desfechos. Mais do que um fluxo de procedimentos policiais e judiciais, esses trabalhos revelam um fluxo contínuo de disputas através de linguagens oral, gestual, escrita e também silenciosa. Senso comum, paradigmas do ambiente organizacional e preceitos presentes nos códigos legais são utilizados para interpretar situações, categorizar pessoas e cenas, elaborar relatos e descrições. Acordos, entendimentos, evidências e fatos são construídos nas interações entre os diversos agentes das organizações do sistema de justiça criminal e entre esses, vítimas, suspeitos e testemunhas (ADORNO, 1994; PIMENTEL et al, 1998; SCHRITZMEYER, junho/2001; VARGAS, 2000).

7 - Entrevista concedida, no intervalo de uma sessão, em 13/06/1997, no $1^{0}$ Tribunal do Júri (Vila Mariana), por Dona Creuza, - 61 anos, "tia-mãe" do réu, conforme ela mesma se auto denominou, e costureira. Era a primeira vez que assistia a um julgamento pelo Júri.
} 
escolhidos por Deus prá serem mais iluminados. Acho que, naquela salinha [a de votação secreta], eles devem ajudar o juiz. Espero que ajudem meu filho (...).

Não bastasse a riqueza dessas comparações, no sentido de revelarem o poder imagético-teatral-religioso do Júri, há detalhes, na fala da entrevistada, que denotam o quanto o cenário, o "figurino" e a performance dos "atores" influenciaram sua interpretação do julgamento. A posição central, destacada, pensativa e predominantemente silenciosa do juiz fez com que a entrevistada o associasse a Deus. A fala verborrágica e, sobretudo acusatória do promotor, levou-a a aproximá-lo do demônio. O discurso do advogado - provavelmente semelhante ao que ela própria faria, caso pudesse - remeteu-a à imagem de anjo da guarda. E a idéia, sempre reiterada, de que jurados são cidadãos idôneos, que deixaram de lado seus afazeres pessoais para prestar um serviço social, foi interiorizada e traduzida pela entrevistada como se eles fossem pontes entre o mundo dos homens e o divino.

Voltando a Maquiavel, durante os julgamentos pelo Júri, talvez tenhamos juiz, promotor, defensor e jurados dividindo a posição de "príncipes". Enquanto o primeiro reina soberano e aparentemente neutro, o segundo acusa veementemente, o terceiro protege e os demais decidem de uma posição quase santificada. Como um deus que se quadriparte, mas justamente por isso se fortalece, a encenação de julgar dramas de vida e morte sacraliza a instituição "justiça estatal", legitimando-a à medida que revigora uma certa etiqueta e estética sociais.

Os "Príncipes do Júri", portanto, podem ser considerados avatares do poder voltados para a conquista, a manutenção e o exercício do controle legítimo do poder de matar. Contudo, para manterem tal controle, devem fazer com que suas imagens e aparências correspondam ao que seus "súditos" desejam e esperam. Assim, príncipes e súditos controlam-se através de expectativas socialmente disseminadas. Em outras palavras, a existência de uma instância de poder estatal, que se pretende legítima monopolizadora do controle do poder de matar, responde, em alguma medida — talvez, em larga medida - , a projeções e demandas da sociedade em que se insere.

Os jurados, nesse quadro, talvez ocupem a posição mais ambígua, pois decidem, mas também devem se comportar como súditos. Sua condição de príncipes, portanto, é a menos pronunciada porque, enquanto juiz, promotor e advogado exibem-se através de falas e gestos, eles mantêm-se calados e praticamente imóveis ${ }^{8}$.

8 - dada essa ambigüidade, mencionaremos, em algumas passagens adiante, os jurados como súditos. 
A entrevistada em questão, projetou e encontrou no juiz, no promotor, no advogado e nos jurados respectivamente a neutralidade, o "bem", o "mal" e o bom senso. Ela admirou e respeitou a sobriedade do juiz, sentiu raiva da veemência do promotor, teve compaixão pelo defensor - como, provavelmente, de seu filho - e acreditou na idoneidade dos jurados. Uma instância de poder e de decisão que condensasse todas essas características num só representante, se exporia mais do que o Júri, pois nela o poder estaria mais desnudo. No Júri, o poder está escondido por detrás de múltiplas facetas e, cada uma delas, embora complementares, apresenta-se, em cena, como independente e até oposta às demais.

Emoções contraditórias, especialmente de assistentes, como as da entrevistada, são assim canalizadas para direções aparentemente distintas - juiz, promotor, defensor, jurados - sendo preservado o conjunto — o sistema judiciário. Ao apresentar-se através de seus vários personagens, o Júri atua em uníssono, embora criando a ilusão de que é fragmentado. Numa só sessão, ódios, compaixões, esperanças e desesperanças são suscitados, dispersam -se e equilibram-se, sem grandes ameaças à instituição Júri.

O Júri mantém-se porque uma das "ilusões" teatrais que ela cria é a de que seus representantes são porta-vozes de valores universais. Ao julgarem dramas aparentemente inter-individuais, segundo valores aparentemente coletivos, juízes, promotores, defensores e jurados disfarçam - para si e para os outros - o caráter social dos dramas e o viés elitista e hierarquizado dos valores em que o sistema se pauta para julgá-los. Neste mecanismo reside a criação de verossimilhanças.

Mesmo quando promotores e defensores do Júri são criticados e apontados como representantes de interesses não universais, a instituição é normalmente percebida e preservada como mediadora e reguladora imparcial de conflitos, tanto que críticas, dirigidas diretamente a ela, costumam ser convertidas em propostas meramente técnicas de agilização da justiça - aumento do número de varas, mais informatização, necessidade de reformas legais, melhores remunerações, novos cursos de formação para operadores técnicos etc. (Loche et al, 1999: cap.VI). Em outras palavras, a instituição ou absorve críticas feitas a sua estrutura, transformando-as em sugestões de aperfeiçoamento dessa mesma estrutura, ou converte-as em críticas a atuações pontuais de alguns de seus membros.

Uma das conclusões que perpassa esta tese, portanto, é a de que a "justiça" praticada pelo Júri, apesar de todas as desigualdades que lhe são intrínsecas, em alguma medida é aceita e legitimada por seus participantes devido à ilusão teatral - e 
maniqueísta - de que algo superior a todos os envolvidos está em jogo e em cena: a luta entre "bem" e "mal", certo e errado, perdão e punição, compreensão e vingança.

Balandier exemplifica a força dessas ilusões, socialmente dramatizadas, remontando à Florença, no final do séc. XV, quando da ditadura do monge dominicano Savonarola: “(...) sua pregação transforma o imaginário em presença. (...). A mecânica empregada para produzir efeitos é a máquina da oratória. O poder adquirido é teatral na acepção mais imediata do termo. (...) Florença é então submetida a uma "ditadura da voz". É com este desempenho que o imaginário e a ideologia se tornam ilusões realizadas."(Balandier, 1982: 6)

O grande ator político, conclui Balandier, "comanda o real através do imaginário", sendo a ópera francesa, do século XVII, um bom exemplo da fertilidade do palco enquanto terreno político: "O imaginário clássico projeta sobre a cena, onde se desenrola 0 drama lírico, as representações de uma ordem onde tudo éharmonia. Produz essa ilusão, e, fazendo-a, justifica-a." (idem: 7)

Podemos afirmar que o denominado "imaginário classe média" de jurados, o conjunto de valores heterogêneos de assistentes e mesmo a postura técnico-elitista dos operadores do Júri projeta-se sobre os casos em julgamento e, em decorrência da encenação que envolve tais projeções, criam-se melodramas que, em alguma medida, dizem respeito a - e fazem sentido para - todos.

Ao produzir a ilusão de que certas vidas - de vítimas de homicídios - e valores a elas atrelados não merecem ser socialmente preservados, o Júri legitima absolvições de réus e, ao contrário, condenações são justificadas quando se produz a ilusão de que outras vidas e valores foram ilegitimamente ceifados. Eis alguns adjetivos utilizados pelo defensor de um réu para qualificar a vítima e, denegrindo-a, compará-la ao réu: " $R$. [vítima] era epiléptico, sedava-se com medicamentos e sofria mudanças bruscas de humor. (...). Vivia envolvendo-se em discussões. Enfim, tinha problemas mentais, era briguento, encrenqueiro... Será que várias pessoas não teriam motivos para matá-lo? (...). O réu, que mora há 28 anos no mesmo lugar, a dois quarteirões da casa da vítima e nunca fugiu, não tinha qualquer motivo, pois a primeira atitude de um marginal é fugir! $!^{9}$

O exercício desse poder de construir mortes legítimas e ilegítimas — ou, se quisermos, absolvições e condenações legítimas - baseia-se muito menos no uso da força e da justificação racional do que na produção de imagens, na manipulação de símbolos e na organização desses em um quadro cerimonial. Justamente esses recursos

\footnotetext{
9 - julgamento realizado em 16/08/2001, no plenário 7, do $1^{\circ}$ Tribunal do Júri (Barra Funda), das $09 \mathrm{~h}$ às $11 \mathrm{~h} 35$ '. O réu foi absolvido por unanimidade.
} 
teatrais, culturalmente sutis e complexos, constróem a legitimidade do poder do Júri e das decisões que produz.

As sessões permitem aos jurados e aos "príncipes" mostrarem-se atuantes, coesos, íntegros e fortes, pois elas são também espetáculos cerimoniais pedagógicos nos quais o sistema de justiça criminal é apresentado, ensinado e aprendido, legitimado e incorporado. Durante seu transcorrer, reúnem-se, "quase" como iguais e aliados, jurados e "príncipes", tanto que há, especialmente nos intervalos para "o cafezinho" e nos momentos finais das sustentações orais de promotores e defensores, uma espécie de exaltação a realizações comuns, como a luta contra a impunidade, a criminalidade e os "vícios" de membros da sociedade. Essas mostram o poderio da "Justiça" dos homens, celebram os desempenhos já realizados e tidos como vitoriosos e apontam o que resta fazer. Trata-se de uma cerimônia que remodela os atores sociais, engajando-os em um espetáculo no qual eles representam não necessariamente o que são, mas o que devem ser em função do que deles esperam "o Estado" e "a sociedade". Trata-se, portanto, de uma dramatização que personifica categorias e entidades como "a Justiça" e "a punição" e mesmo discursos criminológicos, ensinando o que pensar e sentir a respeito deles.

Segundo o discurso criminológico clássico, por exemplo, o criminoso é basicamente alguém que rompeu regras-chave do contrato social e, portanto, é moralmente responsável por isso. Segundo o discurso macrossociológico - também bastante utilizado por operadores do direito —, criminosos e suas vítimas, devido à pobreza econômica e cultural em que, majoritariamente, encontram-se, são produto de um sistema de determinações sócio-estruturais que os impele à situação criminosa. Promotores e defensores, contudo, são praticamente unânimes ao considerar a pena como necessária punição individual - modelo clássico — liberando, assim, o Estado de ser sentenciado a alguma reparação dos danos enquanto co-responsável pela criminalidade.

Nesse sentido é comum, tanto promotores quanto defensores classificarem réus e vítimas como "favelados", "miseráveis", "pessoas que não tinham recursos mais elaborados para resolver seus problemas e, por isso, só puderam usar a força bruta". Em algumas sustentações orais, operadores técnicos colocam-se, explicitamente, ao lado de jurados e juízes, na posição autocrática de quem tem por obrigação "decidir com justiça o caminho daqueles cujas vidas estão em nossas mãos"10.

\footnotetext{
$\overline{10}$ - palavras de uma promotora que atuava na sessão do dia 22/02/1999, num dos plenários do $1^{\circ}$ Tribunal do Júri (Vila Mariana), por volta das 16h30'.
} 
Enfim, a idéia-chave que orienta a maior parte desta análise do Júri enquanto espaço de poder teatralizado é, justamente, a de que “(...) todo poder político obtém a subordinação por meio da teatralidade, (...) ele devolve uma imagem idealizada desta sociedade $e$ portanto aceitável." (Balandier, 1982: 10)

É cabível, portanto, afirmarmos que, em última análise, o poder político do Júri subordina todos os que dele participam, inclusive os próprios operadores técnicos, por meio da teatralidade, a qual é realimentada por valores que cada um desses participantes reedita nos julgamentos.

Os "príncipes do Júri", ao declararem-se representantes da sociedade que governam, respaldados especialmente pelos jurados - que, na mesma cena, passam de súditos a príncipes - criam uma imagem idealizada da sociedade, segundo a qual suas mazelas são desvios a ser controlados, compreendidos, aceitos ou punidos com base em valores "universais". Os "súditos", por sua vez — réus, público —, partilham dessa idealização, em alguma medida, pois é difícil reconhecer mazelas não como desvios, mas como características do caminho principal. A imagem de uma sociedade íntegra, controladora de seus desviantes e preocupada com as vidas dos mais miseráveis — réus e vítimas - constitui o pano de fundo de quase todas as sessões de Júri a que assisti ao longo do trabalho de campo realizado para este doutorado.

Um bate-boca entre uma advogada e um promotor ilustra esse pano de fundo e, ao mesmo tempo, mostra como os dois oradores apresentam-se como contendores que, todavia, compartilham a tese comum da necessidade de controlar desviantes preocuparse com os miseráveis ${ }^{11}$ :

$\Rightarrow$ Promotor: É impressionante como falta coerência à defensora... O réu não agiu em legítima defesa porque atingiu a vítima, na frente de seu barraco, depois de ameaçála, dizendo: "Hoje vamos acertar as contas". A violência dos golpes do réu foram desproporcionais às ameaças da vítima.

$\Rightarrow$ Advogada: Incoerente é o ilustríssimo promotor, que não percebe que o réu não é um robô; que o ser humano não é um robô!

$\Rightarrow$ Promotor: $O$ código não foi feito por robôs, mas por seres humanos, e leva em conta as reações do "homem médio". A doutora sabe disso! Para que uma sociedade exista e controle suas disfunções, protegendo inclusive os mais miseráveis de suas próprias falhas de socialização, é preciso que a lei seja cumprida.

$\Rightarrow$ Advogada: Concordo que a lei deva ser cumprida e que quem agiu em desacordo com ela deva ser punido. Sem lei não há sociedade e sem sociedade não há homens. Especialmente os mais frágeis devem ser protegidos pela lei. Este homem apenas se defendeu e a lei não pune quem age em legítima defesa.

$\overline{11}$ - 13/06/1997, das 13h às 17h, Plenário "D" do $1^{\circ}$ Tribunal do Júri (Vila Mariana). 
Ele e ela discordam quanto ao réu ter agido em legítima defesa, mas, em momento algum, questionam a lei enquanto fundamento e garantia da vida social, com especial ênfase em seu papel "protetor" frente aos "mais miseráveis.

Enfim, conforme já apontamos, a encenação no Júri implica a reiteração de distâncias, hierarquias e mudanças regradas de papéis. Jurados leigos tornam-se juízes; defensores, promotores e magistrados encarnam autoridades e réus são associados àquilo que "a sociedade" deve controlar, punir ou mesmo cuidar. A força do poder do Júri é audível, visível e palpável através de sua teatralidade.

A violência legítima dessa instituição matar moralmente réus condenados ou de deixar os absolvidos moralmente vivos alimenta-se da teatrocracia praticada em cada sessão. A força das execuções é especialmente dramática porque, nos palcos-plenários, executados, executores e assistentes, em carne e osso, exemplificam o que acontece com quem transgride certos interditos sociais e, ao fazerem-no, aprendem e ensinam o que se está ali entendendo por transgressões e interditos.

Os grandes julgamentos, conclui Balandier, “(...) levam a dramatização a seu mais alto grau de intensidade. Eles impõem uma encenação, um cenário, papéis, instâncias secretas e violências, revelações e efeitos de surpresa (...). Recorrem ao extraordinário, inclusive no arranjo do cerimonial judiciário. São calcados em uma lógica implacável, mas seu funcionamento provoca emoções - desde a reprovação até a cólera e o ódio populares. (...) a meta do drama é a morte física ou moral daqueles que o poder acusa em nome da salvaguarda da forma e dos valores supremos da sociedade."(1982: 10)

\section{- Retórica do poder}

A linguagem utilizada nos Tribunais do Júri possui algumas das principais características do que Balandier denomina "linguagem do poder", dentre as quais a tentativa de ser válida para além de uma aplicabilidade imediata e cotidiana. Pode-se dizer que a linguagem do poder no Júri projeta-se em direção ao passado e ao futuro, pois, através dela, evoca-se "justiça" tanto em relação ao que já se consumou quanto ao que poderá decorrer da absolvição ou condenação do réu. Reparação e prevenção são objetivos evocados, direta ou indiretamente, pelos oradores do Júri.

Um promotor foi especialmente claro, nesse sentido, ao conceder-me uma entrevista: "O resultado de um julgamento de homicídio não só deve reparar, ainda que simbolicamente, o dano social, na verdade irreparável, de uma vida perdida, como alertar a todos 
que isso não se faz impunemente. (...). Um ser humano que mata outro, seja por que razão for, mata uma parte de si mesmo e da sociedade". ${ }^{12}$

Além disso, promotores e defensores também enfatizam o que, em suas opiniões, ao invés de particularidades dos casos em julgamento, diz respeito a valores "atemporais”: "(...) o que deve orientar este julgamento são os princípios morais que regem os homens de bem (...)"; ou “(...) o que aconteceu é um retrato da degradação humana (...)"; ou ainda “(...) este caso evidencia que o progresso da humanidade não se dá de maneira uniforme, pois há retrocessos (...)". ${ }^{13}$ Essas frases, mais que meros recursos retóricos e vazios de sentido, atribuem a cada sessão uma razão de ser que as extrapola, uma vez que elas tornam-se exemplos de princípios e valores apontados como social e humanamente relevantes.

Outra característica da "linguagem do poder", segundo Balandier, é que, nas sociedades ditas "modernas", sua validação é explicitamente "técnica" e, em graus diversos, ideológica, diferentemente do que predomina em algumas sociedades ditas "tradicionais", nas quais as palavras dos poderosos são consideradas mensagens de antepassados e/ou de divindades.

$\mathrm{Na}$ maioria das sessões de Júri observadas, mesmo quando promotores e defensores, em suas sustentações orais, pouco recorrem ao jargão jurídico-processual, não deixam de, em momentos-chave, referendar seus principais argumentos através de expressões de caráter técnico-científico e de se remeter a "provas materiais": exames e laudos realizados pelo Instituto Médico Legal — IML —, pela polícia científica etc.

Presenciei sessões em que a leitura de longos trechos de peças processuais tomou vários minutos das falas dos arguidores, fazendo com que as fisionomias da maioria dos jurados passassem do "interesse atento" ao "interesse cansado", culminando com um visível "desinteresse desatento e cansado". Ao entrevistar uma jurada que me pareceu ter chegado a esse último grau de exaustão, tive a oportunidade de indagar-lhe: ${ }^{14}$

$\Rightarrow \mathrm{Eu}:$ O que você achou da leitura daqueles laudos da polícia técnica, no início da fala do promotor?

$\Rightarrow$ Ele: Para ser sincera, no começo prestei atenção, mas, depois, como não fui entendendo muitas palavras, deixei de me interessar. Mas isso não quer dizer que não levei em conta o que foi lido, pois sei que o Doutor estava querendo que a gente soubesse de onde ele tirou suas idéias. Ele queria provar que aquilo que ele falava era verdade e isso é importante, pois senão a gente poderia se sentir enganado (...)

\footnotetext{
$\overline{12}$ - entrevista concedida em 18/03/1999, à tarde, no $4^{\circ}$ Tribunal do Júri (Santo Amaro).

13 - falas de três promotores, em sessões ocorridas, respectivamente, em 11/04, 14/04 e 05/05/1997, no $1^{\circ}$ Tribunal do Júri (Vila Mariana).

14 - Entrevista concedida, na tarde de 14/06/1999, por Carla, 32 anos, professora primária, no $1^{\circ}$ Tribunal do Júri (Vila Mariana).
} 
$\Rightarrow \mathrm{Eu}:$ Então, você acha importante a leitura desses laudos técnicos para os jurados?

$\Rightarrow$ Ele: Acho. Mesmo que a gente não entenda tudo, dá prá perceber que não está di brincando de inventar uma história.

Portanto, mesmo quando o jargão técnico-científico soa ininteligível aos leigos, cansando-Ihes, essa ininteligibilidade pode contribuir para a legitimação dos argumentos utilizados, uma vez que tecnicidade e cientificidade são associadas a seriedade e a recursos para se revelar "verdades".

Afirma ainda Balandier que as palavras do poder não circulam como as outras, havendo em torno delas "uma comunicação calculada", uma busca de "efeitos precisos" que permitem o desvendamento de parcelas da realidade, "(...) pois o poder também deve sua existência à apropriação da informação, dos "conhecimentos" exigidos para governar, administrar, e para exercer seu domínio. Os governantes gostam do segredo, (...). A arte do silêncio é parte da arte política. (...) A prolixidade sobre o acessório mascara o silêncio sobre o essencial, em parte ou no todo" (Balandier, 1982: 13-14).

A complexa linguagem oral, gestual e muitas vezes silenciosa que faz circularem informações durante as sessões de Júri, e mesmo em seus intervalos, seja entre jurados, seja entre esses e defensores, acusadores, juízes, réus e assistentes, possui uma "calculabilidade". Quase nada é comunicado sem uma prévia ou até momentânea estratégia - nem sempre consciente - que visa a apropriação e o controle de informações e conhecimentos.

A proibição, por exemplo, de que, durante os intervalos das sessões, jurados comentem, direta ou indiretamente, assuntos relacionados ao caso em julgamento, é um dos indicadores de que, por se tratar de uma situação que envolve poder, qualquer troca de informações ou de "conhecimentos" deve ser controlada, havendo um especial apreço pelo silêncio, pelo segredo e pela demonstração do domínio de "conhecimentos".

Os votos dos jurados na "sala secreta", contudo, contrastam com a prolixidade técnica da maioria das sustentações orais de promotores e defensores, e tanto o silêncio que envolve os primeiros quando a verborragia característica dos segundos compõem a arte da política no Júri. O poder de legitimar ou deslegitimar determinados comportamentos de réus, vítimas e as conseqüentes mortes representadas em plenário pertence a esse conjunto de "mudos" e "falantes" e por eles é exercido, caso a caso.

Outro aspecto a ser ressaltado em relação à linguagem e ao exercício do poder no Júri é a necessária reiteração de distinções entre "governantes" e "governados", sendo a base dessas distinções um longo processo de construção de qualidades atribuídas a uns 
e não a outros. Vários estudos apontam o fato de que o poder muda os que a ele têm acesso, culminando com rituais de entronização dos que chegam a posições de destaque.

Pode-se dizer que "os poderosos são feitos" (Balandier, 1982:14; Geertz, 1991) porque, normalmente, nascem de um processo social intrincado, que os elege como especiais a medida que passam a representar valores socialmente relevantes. A imagem pública que ostentam, digna de credibilidade, costuma ser construída através de "provas de iniciação" e de menções a seus "sucessos anteriores". Uma vez entronizados, têm a constante obrigação de manifestar, através de recursos cerimoniais, sua competência e sua "sorte", provando assim o autocontrole de suas "forças".

No Júri, uma análise "cênica-política" das distinções entre os que estão no "palco" e na "platéia" - e mesmo da hierarquia existente entre os que ocupam o palco — reforça essas idéias, pois juízes, promotores e advogados, ainda que jovens, distinguem-se dos demais por ostentarem imagens públicas de "doutores". Suas togas e a aura de poder que elas criam costumam ser interpretadas como sinais de sabedoria adquirida através de anos e anos de estudo, aprovação em concursos, experiências de vida e de trabalho acumuladas. Eis a visão de uma entrevistada, irmã de um réu, a respeito das togas:

$\Rightarrow \mathrm{Eu}$ : $O$ que você acha do juiz, do promotor e do advogado de defesa usarem togas pretas durante o julgamento?

$\Rightarrow$ Ela: Acho um sinal de respeito.

$\Rightarrow$ Eu: Respeito por quem ou pelo quê?

$\Rightarrow$ Ela: Acho que eles querem ser respeitados e também estão respeitando gente comum, como nós. (...) Eles estudaram muito prá estarem aí, por isso mesmo, podemos confiar. Vão fazer o que for melhor, o certo (...). Não é qualquer um que se forma doutor, não é mesmo?." 15

As togas, portanto, conferem a juízes, defensores e promotores a marca de autoridades competentes, respeitáveis e respeitadores.

Conforme já apontamos, nos capítulos anteriores, os cumprimentos elogiosos que acusadores e defensores dirigem uns aos outros e aos demais presentes, no início de suas falas, não só hierarquizam e legitimam imagens públicas, como também reiteram competências. Toda a movimentação cênica que executam - deslocamentos pelo plenário, gestualidade, altercações, uso pomposo do jargão técnico-científico, demonstração exaustiva de detalhes do caso etc - reitera e demonstra por que eles estão ali, no "palco", exercendo e exibindo o poder legítimo de julgar.

\footnotetext{
$\overline{15}$ - entrevista concedida em 05/03/1999, por Luiza, 31 anos, auxiliar administrativa, no $4^{\circ}$ Tribunal do Júri (Santo Amaro).
} 
Especialmente o juiz, em sua posição central e suprema, visivelmente mede palavras suas e alheias, assim como o uso do silêncio - seu e alheio - com vistas a produzir efeitos precisos de autoridade. Pode-se dizer que ele "reina" utilizando-se dos recursos cerimoniais do Júri e manifesta, em momentos estratégicos - bate-boca entre promotor e defensor, mau comportamento do réu ou de assistentes - , sua competência para controlar "forças" próprias e alheias. Quando seu domínio é ameaçado, geralmente reage, tal como vimos no primeiro capítulo, quando nos referimos à sessão em que promotor e advogado "invadiram" o domínio do magistrado, levando-o a declarar: "Senhores! São três os que estão agindo aqui como juízes! Eu mesmo e suas excelências! Assim não dá!" 16

Enfim, a dramatização política consagra, comemora, difunde idéias e procura adesões através do espetáculo. No Júri, o controle do poder legítimo de matar é consagrado, comemorado e idéias-valores que o sustentam difundem-se através dos exemplos "palpáveis" que cada caso permite construir. Ao final de cada sessão, de um ponto de vista estritamente antropológico-político, não importa se o réu foi absolvido ou condenado, mas se o espetáculo que o absolveu ou condenou permitiu a seus participantes e assistentes aderirem ao próprio poder em jogo: o poder de legitimar vidas e mortes. O Júri é uma manifestação pública, que a sociedade oferece a si mesma, desse poder.

Não bastasse isso, em cada sessão, tenta-se assegurar prestígio e respeito aos "heróis do drama". A esses são dados assentimento e obediência em troca de demonstrações de poder e de continuidade do poder. Tais heróis, ao contrário do que se poderia pressupor, são menos os réus e as vítimas - dos quais muito se fala - e mais os operadores técnicos e jurados - que muito falam e ouvem. São o desempenho e a capacidade desses que, em última instância, transformam-nos, aos olhos da assistência e deles próprios, em "heróis da justiça".

Disse-me, certa vez, um juiz: "Num mundo como este nosso, em que os principais valores morais e sociais estão em xeque, quem trabalha para que a lei seja devidamente aplicada é um herói, pois luta contra a maré generalizada de descrédito na justiça. (...). Mais pessoas deveriam assistir a júris para entender que existem leis e que elas não servem só de enfeite. E que há muita gente trabalhando por isso. (...). A meu ver, policiais, nós da área jurídica, e todos os cidadãos de bem temos uma verdadeira missão social a cumprir. No Júri, especialmente, os

\footnotetext{
$\overline{16}$ - 04/03/1999, das 9h às 18h30', plenário do $7^{\circ}$ andar do $4^{\circ}$ Tribunal do Júri (Penha).
} 
jurados são verdadeiros heróis, pois são homens e mulheres comuns demonstrando que não só acreditam na lei como que são capazes se aplicá-la." ${ }^{17}$

Essa percepção de juízes, promotores, defensores e jurados de que acreditar na "lei" e aplicá-la é fazer justiça e de que, além disso, tal tarefa é executada por heróis, apareceu tanto implicitamente quanto explicitamente em várias entrevistas. A construção dessa auto-imagem de heróis não deixa de ser mais um recurso da teatralidade política do Júri, uma vez que heróis são reconhecidos "(...) em virtude de sua força dramática. (...). A surpresa, a ação e o sucesso são as três leis do drama que he dão existência." (1982: 7). Promotores e defensores, ao apresentarem o réu como um tipo a ser evitado e banido ou como alguém digno de pena por estar sendo injustamente acusado - anti-herói apresentam-se a si próprios como imprescindíveis para que se faça "justiça", cabendo aos jurados a responsabilidade de dar a derradeira - e legitimadora - palavra.

Uma última observação relativa à "linguagem do poder" no Júri ou à teatralidade política que é evidenciada e consagrada nesse rito judicial é que nele também está em jogo o que Balandier denomina de "efeitos compensatórios do poder" ou "poder em negativo". A idéia é a de que, devido à sociedade estar em contínua construção e, consequentemente, conter vulnerabilidades e perturbações, as representações que ela faz de si mesma compensam suas desordens e contradições internas: "A sociedade não depende exclusivamente da coerção, das relações de força legitimadas, mas também do conjunto de transfigurações de que é, ao mesmo tempo, o objeto e a realizadora. Sua ordem permanece vulnerável; ela é portadora de perturbações e de desordem geradores de ardis e dramatizações que mostram o poder em negativo." (Balandier, 1982: 21)

Conforme já sugerimos, anteriormente, o ritual do Júri cumpre uma função de compensação à medida que, por algumas horas, nos plenários, uma sociedade de crescentes e gritantes diferenças sócio-econômicas articula-se em torno de valores que ela própria apresenta como universais. Essa pretensa unidade social, exemplificada a cada caso, é um dos pontos-chave da linguagem dramática, em geral e do Júri, em particular.

No tempo e no espaço precisos de um julgamento, a noção de pertencimento de todos a um só conjunto, apesar de suas ambigüidades, passa de idealização a algo palpável. Quem assiste e participa de um Júri não pensa que a sociedade existe, sente-a: "A palavra, pela sua força e seus efeitos, ilusiona para conseguir que a idéia se realize; e também para manipular na teatralidade e na ambigüidade. "(Balandier, 1982: 13)

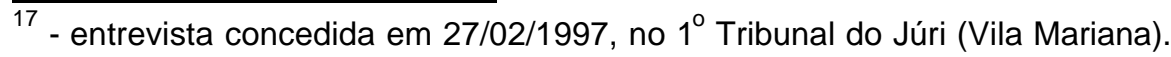




\section{- Uma faceta burlesca: a desordem garantindo a ordem}

Antigos esquimós da Groenlândia duelavam, cantando, para regular um conflito entre dois oponentes. Travavam uma guerra de palavras, zombarias, insultos e obscenidades; ridicularizavam -se numa luta verbal e espetacular, num possível jogo de alto risco. Saía-se vencedor aquele que mais despojasse o outro de sua auto-estima e do respeito de seus associados: “(...) o temor do ridículo é imanente, seu ataque mata simbólica ou realmente e com tanto ou mais eficiência quanto maior a projeção social da vítima." (Balandier 1982: 23-24)

Num dos processos de homicídio que estudei para um trabalho executado para a FSEADE - Fundação Sistema Estadual de Análise de Dados ${ }^{18}$-, essa antiga prática esquimó foi quase literalmente reeditada entre réu e vítima e também entre defensor e promotor. Consta que, na tréplica do julgamento ocorrido em 10/05/1994, no $4^{\circ}$ Tribunal do Júri da Penha, o advogado do réu, defendendo a tese de homicídio privilegiado praticado sob violenta emoção, após injusta provocação da vítima —, leu a letra da música "O Cheiro da Maçã", sob protestos do Promotor:

"Toda noite é a mesma coisa/ Eu procuro e você não quer/ Faz de conta que está dormindo/ Nem parece que é minha mulher/ Tão cansada, vira pro lado/ E eu na cama, sofrendo calado/ Quatro horas da manhã, sinto o cheiro da maça/ E o perfume do seu corpo/ Vejo tudo se perdendo/ Você fria me esquecendo/ Pela cama, pouco a pouco/ E bate uma vontade louca de beijar sua boca e matar meus desejos/ Outra noite de castigo/ Sem tocar seu corpo/ Sem ganhar seus beijos/ Já começa um novo dia/ E minha fantasia ficou na saudade, outra vez/ Eu vou sofrer sem carinho/ E sem você outra noite/ Estou perdido/ Eu passei batido e não amei você".

Tal música, segundo o defensor, fora cantada pelo vizinho do réu, no quintal comum aos dois barracos, pouco antes de o réu baleá-lo, prova de que assim agiu sob violenta emoção, pois o vizinho tinha um caso com sua mulher e usara a música para humilhá-lo. Embora não constem do processo quaisquer detalhes sobre como se deu a leitura dessa música em plenário, há várias peças narrando, segundo testemunhas e o próprio réu, o "duelo musical" entre ele e a vítima. Depreende-se que, em plenário, a leitura da letra também causou tumulto, pois, na ata da sessão do Júri, há registros de que o promotor protestou contra a maneira de o defensor ter conseguido a letra durante o transcorrer da própria sessão, pedindo a um primo do réu, presente em

18 - Convênio IBCCRIM/FSEADE, 2001 - "Fluxograma para o processamento dos crimes de competência do Tribunal do Júri” In Boletim IBCCRIM. São Paulo: IBCCRIM, $\mathrm{n}^{\circ}$ 109, dezembro/2001 - encarte central). O processo em questão é o de n ${ }^{\circ}$ 1045/91. 
plenário, que a transcrevesse. O juiz acabou determinando a juntada do manuscrito com a letra, o que significa dizer que autorizou os jurados a considerarem-na como prova do estado de espírito do réu.

Lamentei não ter estado presente a essa sessão, inclusive para comparar o que ocorreu em cena com o que restou registrado nos autos. De qualquer modo, o exemplo é válido para, guardadas as devidas proporções, afirmarmos que esse réu, em plenário, fez o papel de "bufão", devidamente acompanhado do acusador e do defensor enquanto "comediantes burlescos". Esses, através de sustentações orais calcadas em exageros e caricaturas do acusado e da vítima transformaram-nos em personagens perturbadores da lógica social, das convenções e da "moral comum" - monogamia feminina - e, por isso mesmo, reveladores de ambigüidades humanas — bigamia feminina, traição, amor e ódio — a serem devidamente ritualizadas e "resolvidas" no julgamento.

O bufão "(...) mostra que as classificações impostas pela sociedade e pela cultura podem ser confusas; ele parece destruir para reconstruir de modo diferente; ele cria na desordem; ele apresenta uma imagem adoidada e heróica da aventura individual, conduzida fora das convenções sociais. (...). Seu espetáculo ironiza (...), sendo uma força sacrílega, por excelência (...). [mas] $A$ transgressão é limitada pelo ritual, não se confundindo nunca com a orgia”. (Balandier, 1982: 30)

É difícil, ao equipararmos a dramaticidade do Júri a um espetáculo burlesco, deixarmos de lembrar Durkheim definindo a normalidade sociológica do crime pois, tanto na figura do bufão quanto na proposição durkheimniana de que o crime cumpre funções sociais importantes - como o reforço da ordem e a antecipação de comportamentos futuros (Durkheim, 1983: 119-124) — prevalece a idéia de que a encenação da desordem é um modo de reiterar e garantir a ordem.

Não bastasse isso, o bufão também cumpre uma função catártica, a medida que libera tensões e, assim, trabalha para a regularização de relações sociais: "Embaralhador de cartas, ele é também fator de ordem. Ele suprime as disciplinas e contribui para restaurá-las. Ele transforma, por meio do imaginário e do espetáculo, os fatores reais da ruptura em figuras dramáticas. (...) Ele se torna portador do anti-social - (...). Ele mostra o que sucederia a uma sociedade em que as normas, interditos e os códigos se dissolvessem (....). Cabe-lhe a parte do fogo, mas a fim de extingui-lo; não se pode reconhecer nele a prefiguração do revolucionário ou mesmo a do rebelde." (Balandier, 1982: 30 -31)

De uma ótica teatral, as narrativas de homicídios apresentadas no Júri reforçadas pela presença do réu, por fotos do cadáver da vítima, por ataques veementes do promotor e por igualmente fortes contra-argumentos do defensor - são performances que, dentre outras finalidades, execram, de forma catártica, comportamentos e modos de 
vida considerados caóticos e perigosos. Quando esses são ridicularizados é como se "pecados", "falhas" e "defeitos" humanos também fossem execrados. Sem contar que há algo igualmente catártico quando jurados, através de seus votos e em nome da "sociedade", liberam a tensão acumulada durante as horas de julgamento, dando um desfecho ao caso.

Promotores e defensores, em plenário, ao narrarem desordens e fatores de ruptura familiar, moral e econômica envolvidos nos crimes, geralmente transformam -nos, por meio do imaginário e do espetáculo, em figuras dramáticas - papel típico do bufão. Transformam, assim, réus em portadores do "anti-social" e mensageiros de contestações e incongruências, mas com a finalidade precípua de, ao final da sessão, os jurados, através de seus veredictos, porem ordem ao caos ou, em outras palavras, darem um destino às contestações e incongruências que réus e vítimas representam.

$\mathrm{Na}$ encenação e no jogo do Júri, além de ridicularizações que podem envolver diretamente réu e vítima, no contexto do crime, há pelo menos outras duas que, de certa maneira, aproximam-se do velho duelo esquimó. Às vezes, réu e/ou vítima são escarnecidos por operadores técnicos, diante de todos, ao serem apontados como "pessoas sem condições de compreender a ordem social e dela participar devidamente" ${ }^{19}$ Também, não raras vezes, defensores e promotores trocam, entre si, ironias, insultos e zombarias no que diz respeito a suas próprias performances e conhecimentos jurídicos, na tentativa de, desqualificando-se enquanto oradores competentes, desqualificarem aqueles por eles representados.

$\Rightarrow$ Promotor: Com todo o respeito, doutora, se a senhora tivesse estudado mais, perceberia que não se sustenta a tese da legítima defesa.

$\Rightarrow$ Advogada: O senhor está sugerindo que eu sou uma advogada que não estudei o bastante?

$\Rightarrow$ Promotor: Que é isso, doutora!! Estou me referindo ao estudo dos autos, mas já que a carapuça serviu...

$\Rightarrow$ Advogada [dirigindo-se ao juiz]: Excelência! Eu gostaria que constasse dos autos minha indignação diante dessas sérias ofensas do Senhor Promotor à minha formação e competência e de afirmar que meu cliente e a OAB estão aqui muito bem representados, ao passo que a sociedade, através desse colega do Ministério Público, não está sendo honrada." 20

\footnotetext{
19 - frase de um promotor, dita no transcorrer da sessão do dia 08/03/1999, à tarde, no plenário "B", do $2^{\circ}$ Tribunal do Júri (Saúde).

20 - 13/06/1997, das 13 h às 17 h, Plenário "D" do $1^{0}$ Tribunal do Júri (Vila Mariana).
} 
A frase final da advogada deixa claro que tanto ela quanto o promotor representam outras pessoas e instituições, de modo que ofensas trocadas entre eles colocam em xeque a reputação dos representados.

"Ridicularizações rituais", de um ponto de vista amplo, dramatizam rupturas sociais para que a própria sociedade elabore temas relativos a ambigüidades da condição humana, como o sagrado e o profano, o destino e o livre-arbítrio, o infortúnio e a razão; impulsos e regras culturais.

No Júri, ambigüidades dessa natureza podem ser observadas quando alguns promotores acusam e ridicularizam os réus pelo mau uso do livre-arbítrio, pela carência de projetos "dignificantes" de vida e por uma indevida "socialização" — ruptura de regras sociais básicas devido a impulsos e paixões.

Defensores, por sua vez, ou concordam com promotores e reconhecem a impulsividade e passionalidade de seus clientes, mas, por isso mesmo, para escusá-los de dolo e até de culpa, ou discordam e, quase nos mesmos termos, provam o bom uso do livre-arbítrio - legítima defesa, por exemplo - e a existência de projetos "dignificantes" de vida — trabalho, família, primariedade etc - "apesar" da pobreza e da miséria social e econômica.

Enfim, chega a haver algo de burlesco em algumas sessões de Júri, quando defensores e acusadores, sutilmente ou não, imprimem um tom cômico, grotesco, caricato e satírico às imagens que criam e utilizam em suas narrativas a respeito de réus e de seus próprios desempenhos profissionais.

Voltando à denominação dos juízes, promotores, defensores e jurados como "príncipes", podemos agora sugerir que o par "bobo da corte - príncipe" pode ser relevante numa análise da teatralidade do Júri, pois esses personagens “(...) servem para mostrar o poder sob o duplo aspecto da força e da zombaria, da fortuna e do infortúnio; eles formam um par dramático." (Balandier, 1982: 32). No Júri, temos o réu representando o infortúnio e, muitas vezes, fazendo as vezes de um bobo da corte, perante os presentes. Nos "príncipes", encontramos a força e a representação da fortuna. O poder no Júri, portanto, apresenta-se sob a forma desse par dramático, condensando o duplo aspecto da força e da zombaria, da fortuna e do infortúnio no jogo que se desenvolve entre "príncipes" e réus.

"O Perturbador, (...) o Bufão, (...) o Doido (...). Eles são encarregados da verdade: debaixo da ordem social, a desordem; debaixo das instituições, a violência; debaixo do poder investido da função de manter a estabilidade, o movimento; debaixo da unidade, as fraturas irredutíveis. Entretanto, toda verdade que não pode ser manifestada deve ser tratada. Ela está encerrada, 
confinada. (...). Cada sociedade, a seu modo, define as verdades que tolera, (...) o espaço que ela concede à liberdade modificadora e à mudança. Ela não cessa jamais de restabelecer demarcações, de reavivar os interditos, de reproduzir os códigos e as convenções.” (op. cit: 39).

Os réus, cujas vozes equalizadas ecoam pelas bocas de acusadores e defensores, são por eles apresentados como perturbadores da ordem, bufões, doidos. As histórias contadas a seu respeito falam de desordens, violências, movimentos e fraturas sociais irredutíveis. Mas o essencial do jogo dramático do Júri reside na estratégia astuciosa e complexa de converter ameaças "à sociedade" em meios de fortalecêla (Balandier, 1982: 23). O controle do uso legítimo do poder de matar, portanto, revela-se um dos controles ou modos culturais de lidar - e/ou esconder - rupturas e incongruências sociais. Enfim, a desordem, quando ritualizada e encenada, converte-se em garantia da ordem. Nas palavras de Balandier "A ordem e a desordem da sociedade são como o verso e o anverso de uma moeda, indissociáveis. Dois aspectos ligados, dos quais um, à vista do senso comum, aparece como a figura invertida do outro. Esta inversão da ordem não é sua derrubada, dela é constitutiva, ela pode ser utilizada para reforçá-la. Ela faz a ordem com a desordem, assim como o sacrifício faz a vida com a morte, a "lei" com a violência apaziguada pela operação simbólica."(Balandier, 1982: 41)

Nesse processo de inversão da ordem para, ao final, reiterá-la, pessoas são discriminadas social, moral, sexual, econômica e/ou politicamente. Réus, em última análise, são tão necessários à ordem quanto as instituições que se propõem a preservá-la e aqueles que as representam.

Vários antropólogos já demonstraram que coletividades tradicionais localizam seu mal ao apontar um feiticeiro, num processo de inversão que opõe positivo/negativo e forças de coesão/desagregação social. O temor de ser suspeito de feitiçaria acaba corrigindo condutas e retificando desvios. Um momento intenso desse tipo de situação dramática se dá quando o feiticeiro é procurado, castigado e até eliminado. "Designando publicamente, e, depois, eliminando o autor da crise - (...) - a comunidade se refaz e a autoridade se reforça. A culpabilidade do feiticeiro inocenta todos os outros e, principalmente, os membros do poder. Seu sacrifício contribui para uma volta à ordem dramatizada pelo ritual da execução, a uma restauração das instituições e dos pensamentos que as legitimam. Durante algum tempo, a eliminação do culpado restabelece uma espécie de sociedade purificada. A operação do sacrifício transformou uma comunidade enfraquecida, minada pela desordem engendrada, em uma comunidade regenerada. O poder se nutriu com suas próprias fraquezas ou com seus próprios excessos." (Balandier, 1982: 43). 
Comparando o papel cumprido pelos feiticeiros das coletividades tradicionais ao dos réus do presente, o que se aplica ao processo de inversão na feitiçaria parece aplicável ao processo de designação pública e de eliminação simbólica de autores de crimes. Como a sociedade e seu poder não conseguem evitar a confrontação da ordem e da desordem, da conformidade passiva e da liberdade modificadora, mudam as formas, mas permanece o processo de designação e de neutralização de culpados. "Nas sociedades modernas mais avançadas, (...) os marginais e os dissidentes transtornam as relações estabelecidas pela ordem "normal" com a natureza, o sexo, o trabalho, a economia, o poder, os valores; (...) mas provocam também, e mais fortemente, reações de rejeição que contribuem para a manutenção da conformidade. (...). O poder tem a capacidade de manipular dretamente e em proveito próprio o processo de inversão"(op. cit: 45).

É inegável que o processo de designação e de neutralização de culpados engendra a dinâmica do sistema de justiça criminal e, consequentemente, também do Júri. Réus - "irredutíveis" - são os agentes nefastos ou inimigos internos que, uma vez "sacrificados", inocentam o poder e a coletividade, permitindo o reforço de sua coesão. Natureza, sexo, trabalho, economia, poder e valores são, portanto, transtornados e, simultaneamente, reforçados por réus e/ou vítimas "dissidentes".

A ordem, assim, extrai da desordem as forças que a revigoram, tanto que muitas cerimônias dramáticas ritualizam um período primitivo de violência e sexualidade livres, permitindo à sociedade reavivar e interpretar sua gênese, mas com o objetivo último de, com essas dramatizações, reguladas por leis de inversão e de hipérbole, reordenar valores e garanti-los.

Mais uma vez, remetendo-nos a "sociedades tradicionais", durante a vacância do poder real, em algumas delas se pode observar uma desordem instituída, durante a qual o novo rei encontra meios para reavivar a força de sua realeza. Sua pessoa ambígua objeto de veneração, por um lado, mas de temor e medo, por outro - é assim afirmada e revitalizada em rituais que transcorrem durante esse interregno (Balandier, 1982: 49).

$\mathrm{Na}$ tradição marroquina, ocorre uma breve substituição do verdadeiro poder por um falso, quando reclamações e aspirações frustradas estão perigosamente acumuladas. Em um sistema como esse, de domínio total, a temporária substituição do soberano introduz um movimento de simulacro que praticamente descarta o risco do "verdadeiro" poder ser ameaçado (op. cit: 51). Da mesma forma, subversões festivas, como o Carnaval, afrouxam tensões sociais, apagando constrangimentos, mascarando a miséria, funcionando, enfim, como uma "válvula de segurança" (Da Matta, 1983). "A função de 
terapia social — servir à ordem, revigorando-a — é, incontestavelmente, mais importante do que o risco de ruptura”. (Balandier, 1982: 57)

Antropologia e Direito encontram -se, portanto, frente a frente — ou lado a lado? nesse grande embate entre ordem e desordem, pois não há como compreender a manutenção da primeira sem a existência e as artimanhas sociais utilizadas para controlar a segunda e sem relacionar, ambas, aos sacrifícios que lhes dão força. O Júri está aí para nos mostrar a atualidade dessas estratégias culturais.

\section{- Cenografia política}

Tudo que já foi exposto neste capítulo permite-nos reiterar que, embora o Júri seja um ritual marcado pela atuação de operadores técnicos, são os efeitos dramáticos por eles produzidos que sustentam essa instituição enquanto locus socialmente reconhecido e legitimado do controle do poder de matar. Em outras palavras, o domínio do político e do jurídico, no Júri, apesar de todas as crescentes reivindicações de predomínio de racionalidade e de tecnicidade, não conseguiram transformar esse campo de ação política num espaço privilegiado da razão e da ciência. Isso deve-se ao fato de que dispositivos simbólicos, práticas codificadas e conduzidas segundo regras rituais, além de projeções dramatizadas, advindas do imaginário dos participantes, são intrínsecos ao Júri paulistano e, provavelmente, ao brasileiro.

A idéia de que o poder político, na atualidade, longe de estar "desencantado", apoia-se em algo de natureza simbólica e "mágica" (Balandier: 1982: 61) é especialmente visível no ritual do Júri, pois acusadores e defensores só tornam eficazes suas argüições quando as "encantam" com expressões dramáticas, como a mencionada música "O Cheiro da Maçã".

Se “(...) qualquer universo político é um cenário ou, mais genericamente, um lugar dramático em que são produzidos efeitos" (Balandier, 1982: 63), então podemos caracterizar o Júri tanto como um universo político, quanto como um cenário em que são produzidos efeitos teatrais. Em outras palavras, uma vez que o poder político, em geral, e o do Júri, em particular, conserva a função de desativar angústias e medos (op. cit: 64), a cenografia pol ítica do Júri necessita, para garantir a eficácia da instituição, da produção de imagens e de efeitos não somente técnico-científico-racionais, mas de recursos dramáticos que "toquem os corações" ao tratar de paixões, conflitos, traições.

Explicanos, Balandier, que, geralmente, "Uma dissociação separa (...) o poder supremo, guardião dos símbolos (...) [do] poder de gestão quotidiano. Este está sujeito diretamente 
ao assalto das críticas e às reações da opinião; opera à maneira de uma tela protetora.(...). Os poderes modernos não eliminam os investimentos míticos necessários a seu funcionamento; (...) ". (op. cit: 65)

Partindo desse pressuposto, podemos afirmar que o poder "de gestão quotidiano" do Júri é justamente o técnico-jurídico e, por isso, a esmagadora maioria das críticas e reações da opinião pública quanto a sua existência e eficácia voltam-se para debates sobre o despreparo de jurados leigos, a morosidade do sistema de justiça, os altos custos dos julgamentos etc. Contudo, o "poder supremo, guardião de símbolos" que, de fato, responde pelo funcionamento do Júri, é da ordem de "investimentos míticos", envolvendo, a organização e a expressão de emoções e modelos de conduta bem como crenças na neutralidade do juiz togado; na proteção de interesses "sociais" a ser garantida pelo Ministério Público; na punição e na contenção de "desviantes" pelo Sistema de Justiça Criminal e até na idéia de que vivemos numa democracia participativa na qual leigos podem integrar as decisões do Poder Judiciário.

A cenografia política do Júri, portanto, obedece a uma lógica de hierarquização, composição e atuação dos atores em plenário, muito menos calcada em prescrições legais e formalidades técnico-jurídicas e muito mais em complexos mecanismos de manipulação de sentimentos. Tais prescrições e formalidades, contudo, funcionam como "telas protetoras" do Júri, pois enquanto fortes críticas as atingem, o que realmente importa é resguardado e perpetuado.

O juiz - mito da neutralidade - ocupa, desse ponto de vista, a função soberana de "gestor quotidiano", reinando do alto de sua mesa centralizada e através de suas participações marcadamente técnicas. Porém, ele mais reina do que governa, pois promotores, defensores e jurados são os que abertamente produzem, organizam e reproduzem investimentos míticos e institucionais ao explorarem angústias, medos, valores e modelos de conduta.

Enfim, há exigências contraditórias impostas aos diversos atores políticos do Júri, especialmente aos acusadores, defensores e jurados pois, por um lado, por fazerem parte de uma sociedade em que a técnica e a ciência são consideradas garantidoras da imparcialidade e da justiça, eles submetem-se à lógica da racionalidade competente e, em nome dessa, fixam limites do possível e do razoável em seus discursos, objetivos, escolhas e decisões. Por outro lado, "(...), eles só podem dar a impressão de poder recorrendo ao imaginário, ao irracional, ao simbólico, às armadilhas das esperanças dos governados. (...). Os tempos de crise ou de dificuldades pouco solúveis, como as enfrentadas pelos países em desenvolvimento, requerem também (e em grau superior) uma personalização e uma dramatização 
do poder. A gestão técnica não basta para produzir estas imagens, tanto quanto não chega a dar a ilusão de um domínio completo (...)" (Balandier, 1982: 66-67).

Em parte, essas exigências contraditórias se resolvem por serem os jurados leigos os mais associados e responsabilizados pela "impureza" da gestão técnica, mas, em parte a cenografia política do Júri aponta para a permanência de um poder ambíguo, pois, simultaneamente, revestido de expressões técnico-jurídicas e dramático-simbólicas.

Por paradoxal que pareça, as expressões técnico-jurídicas abrem espaço e dão força às expressões dramático-simbólicas, dependendo delas para não se mostrarem incompletas e ineficazes. Essas segundas, por sua vez, ganham especial impacto por se inserirem num ritual técnico-judiciário. Há, portanto, uma oposição necessária, porque complementar, entre essas expressões e aqueles que Ihes dão vida, fazendo do Júri e de seus atores um conjunto aparentemente carregado de ambigüidades, mas, na verdade, em equilíbrio.

\section{- Tela}

Costuma-se afirmar que, ao contrário das chamadas "sociedades tradicionais" essencialmente vocais - , as "modernas" generalizam a escrita, a impressão das idéias e substituem a argumentação pela demonstração. Contudo, nas sessões do Júri, as argumentações de acusadores e defensores têm muito poder porque, dentre outras razões, os jurados não lêem, previamente, o que está demonstrado nos autos — quando muito, ouvem, em plenário, a leitura de peças indicadas pela defesa ou pela acusação ou nelas passam os olhos, em silêncio e rapidamente, por terem ficado com alguma dúvida ou curiosidade. A argumentação vocal e a dramaticidade do espetáculo do Júri, em si, portanto, são essenciais nos julgamentos.

Isso, talvez, insira-se num processo maior que, graças ao desenvolvimento da mídia eletrônica nas ditas "sociedades modernas", revalorizou antigos hábitos como os da onipresença da palavra - através do rádio - e da invasão progressiva da imagem através da TV: “(...) a tela torna-se o lugar onde tudo pode ser mostrado sob um aspecto dramático para que se formule um julgamento,(...). A persuasão política depende (...) daquilo que é manifestado espetacularmente (...)."(Balandier, 1982: 67 e cap. 4)

Numa sessão, um promotor, ao dirigir-se aos jurados, em seus cumprimentos iniciais, quase chegou a pedir-lhes desculpas pelo fato de o Júri ser um espetáculo mais vocal do que imagético: "Sei que os Srs. são obrigados a vir, mesmo que não tenham facilidade de guardar dados pela audição, uma vez que vivemos no mundo da TV. Trata-se de uma tarefa 
árdua e exigente essa que a Justiça Ihes pede. Mas imaginem o que Ihes será narrado, visualizem as cenas em suas mentes (...). ${ }^{21}$

A palavra, no Júri, portanto, tem o poder de construir imagens. Quanto maior o poder argumentativo do narrador, provavelmente mais será instigada a imaginação dos ouvintes. Para que essa comunicação seja bem sucedida, todavia, faz-se necessária uma "tecnologia das aparências", da qual qualquer tipo de poder normalmente dispõe e depende. Tal tecnologia permite ao poder produzir "(...) a impressão de certa transparência; de suscitar a conivência passiva ou ativa de numerosos governados-espectadores com o sentimento de uma liberdade de determinação - em face da imagem introduzida no universo privado - e de uma possibilidade de participação - graças às intervenções que the são propostas" (Balandier, 1982: 67).

Vários fatores contribuem para a composição dessa "tecnologia das aparências" no Júri como, por exemplo, as sessões serem abertas ao público; a seleção e o sorteio dos jurados serem, a princípio, aleatórios; promotores e defensores apresentarem "dados processuais" a leigos e os jurados serem considerados livres para decidir, através de seus votos. Tudo isso confere uma "impressão de transparência" aos julgamentos, bem como sugere que os jurados desfrutam de liberdade para participar e intervir na ordem social. Assim, generaliza-se a crença de que as palavras que ecoam nos plenários portam "verdades". Um jurado, ao ser entrevistado, declarou: "Depois que a gente participa de um Júri, fica mais fácil e mais difícil criticar o Judiciário, pois a gente fica conhecendo ele melhor, por dentro. (...). Dá prá perceber o que pode melhorar e o que já está bom. Sem contar que, como jurados, nós decidimos, fazemos parte, ficamos mais próximos da verdade (...)" 22

Embora já tenhamos apontado, no capítulo anterior, a ligação entre ritual, festa e poder, cabe reiterar que a festa é, antes de tudo, um meio de transgressão essencial, aceito e suportado no curso da vida social e política; “(...) ela pode armar cenas provisórias em face da cena permanente do poder; ela faz aparecerem figuras efêmeras da liberdade e da irreverência. (...) é esta sua função principal." (op. cit: 75).

A diminuição de festividades sociais e de uma certa "liturgia da desordem", em que as violências se liberam para depois domesticarem-se em dramatizações coletivas, ou seja, a diminuição de "crises miméticas" - que mascaram crises reais —, ao final das quais a ordenação social é reforçada, talvez seja um dos fatores que contribui para o crescimento da violência nas sociedades modernas (op. cit: 76). Nesse sentido, o Júri

\footnotetext{
21 - 16/08/2001 - $1^{\circ}$ Tribunal do Júri (Barra Funda).

22 - entrevista telefônica concedida em 27/06/2001, pelo Sr. Sérgio, tecnólogo, 44 anos.
} 
contribui para manter a violência "sob vigilância", a medida que se constitui enquanto espaço legítimo de ordenação e reforço da ordem social.

Se Balandier tinha razão ao afirmar que "O homem deste fim de século [séc.XX] está preso no casulo invisível formado por todas as redes que Ihe transmitem, à distância, imagens e ruídos do mundo. (...) ele está encerrado; (...) ele tem menos acesso à realidade do que a uma telerrealidade. (...), então podemos associar o Júri a um dos fios que formam esse casulo, pois, em alguma medida, essa instituição mediatiza mortes cotidianas e violentas, bem como os respectivos dramas cotidianos e violentos que as causam, apresentando-os narrados e "processados" nos plenários. Entretanto, prossegue o autor, "este encerramento sofre arranhões. A passividade deslumbrada não exclui momentos de desenganos e de dúvida. $A$ vida cotidiana concreta, direta, rude, pesa sobre a tela das aparências e de vez em quando a rompe" (Balandier, 1982: 78).

Esses momentos de desengano, dúvida e ruptura da tela do Júri, às vezes, podem ser observados imediatamente ao término das sessões. Certa vez, uma mãe, após ouvir a sentença condenatória de seu filho, saiu para o corredor e, em prantos convulsivos, desabafou: "O que falaram aqui não tem nada a ver com o que aconteceu lá. Ninguém sabe o que meu filho passou. Não dá! Vocês entendem? Não dá prá saber o que ele viveu e o que ele fez, ouvindo o que disseram aqui. Não dá! Julgar um homem assim, nesta bolha de vidro, é errado. Acho que só Deus pode julgar diferente, pois só ele estava lá e viu. Só ele sabe de tudo...(...)”."23

Gravei esse depoimento sem o consentimento dessa senhora, cujo nome jamais soube e o julgamento de cujo filho não acompanhei, pois eu simplesmente estava no corredor, aguardando um juiz que me concederia uma entrevista, mas lembro-me que saí dali pensando na imagem do Júri enquanto "bolha de vidro". Casulo invisível.

\section{- Drama, melodrama ou tragédia?}

O desabafo dessa mãe e outras situações relacionadas ao Júri poderiam sugerir que sua teatralidade baseia-se num gênero trágico, mas o Júri lida com dramas e melodramas, pois, nos plenários, não temos deuses, heróis ou personagens ilustres dialogando entre si, como ocorre nas tragédias. Nesses palcos, através de discursos de "príncipes humanos", comportamentos e valores de profanos réus são apresentados, com alta dose de sentimentalismo, a profanos jurados. Temos pessoas "comuns" julgando e decidindo destinos de outras pessoas "comuns". Mesmo quando a situação do julgamento é associada a imagens sacras — deus, demônio, anjo da guarda, santos —, temos muito

23 - fala gravada em $17 / 08 / 2001$, por volta das $18 \mathrm{~h}$, no corredor do $\uparrow$ Tribunal do Júri (Barra Funda). 
mais um rito de reforço de hierarquias, estabelecidas e mantidas entre homens, do que uma cerimônia de caráter divino ou heróico.

Além disso, na maior parte dos casos, ao contrário dos desfechos fatais das tragédias, a estrutura narrativa das sustentações orais de promotores e defensores corresponde a um acúmulo de negatividades que, ao final, sucumbem ao bem, à aplicação da justiça, à punição do socialmente inadmissível ou ao perdão do admissível. "O melodrama requer que o mal seja abatido - o que é uma idéia moral." (Balandier, 1982:33). Esse combate do mal, somado ao fato de os casos julgados remeterem-se a situações populares e violentas do cotidiano, também tipifica o melodrama.

Portanto, ao contrário do que se poderia concluir apressadamente, o que vai a Júri não são histórias trágicas, mas dramas básicos da existência humana, contados a partir de facetas populares e violentas. Isso explica, por exemplo, por que um jurado branco, de classe média, absolve um réu negro e pobre acusado de matar o estuprador de sua pequena filha. Esse jurado, provavelmente, antes de se ver como homem branco e de classe média, identifica-se com o réu enquanto pai, pois o drama mais básico em questão não é o da cor da pele ou o da classe social, mas o do dever paterno de proteger a integridade física e moral da filha, ainda menina, até as últimas conseqüências ${ }^{24}$.

Esse tipo de identificação, fundada naquilo que, num dado contexto, é reconhecido como valor humano universal, é o que está em jogo e em cena, a cada sessão de Júri. Os casos mudam, os valores e identificações em debate variam, as responsabilidades em xeque ora são paternas, ora maternas, ora conjugais, filiais, de vizinhança ou de grupo, mas, geralmente, a estrutura melodramática narrativa repete-se e gira em torno de um ou mais valores cuja universalidade está se testando e reeditando. Acusadores, normalmente, tentam convencer os jurados de que um valor social básico foi desrespeitado pelo réu, ao passo que defensores tentam convencê-los de que outro, ainda mais básico, foi desrespeitado pela vítima, justificando-se, assim, sua morte.

Para que o melodrama chegue a um desfecho, não fatal como na tragédia, mas redentor, é crucial a forma como tais valores são encenados, ou seja, como os atores encarnam seus papéis, pois o melodrama não existe a priori, mas se faz em cena. Nele, portanto, são chaves os processos de identificação e totalização. Nessa lógica baseia-se o modelo narrativo e teatral do Júri, da teatrocracia ali presente, regulando a legitimidade

\footnotetext{
24 - No filme Tempo de Matar - A time to kill —, baseado em livro de John Grisham (EUA, 1999, Warner Bros.), esse melodrama é exemplarmente apresentado.
} 
de vidas e mortes e possibilitando, em ato, consensos mais profundos do que outros cujas bases são racionais.

A melodramaticidade do Júri, portanto, é o que lhe garante a possibilidade de desfechos aceitos como socialmente redentores e juridicamente legítimos. Tal como na tourada o toureiro identifica-se profundamente com o touro, no jogo de vida e morte que os envolve, jurados envolvem-se com réus à medida que, no decorrer das sessões, expõem-se a profundas identificações com os valores contidos em suas histórias. Quanto mais as decisões condenatórias ou absolutórias tiverem tais valores por base, mais o Júri se fortalecerá enquanto instituição encarregada de controlar o uso legítimo do poder de matar.

O melodrama explicita, ainda, a possibilidade da existência de um lugar do qual os participantes exercem e/ou submetem-se a um poder quase absoluto, mesmo que imaginário, tal como ocorre em ritos de passagem. Conforme já apontamos, há pelo menos dois desses ritos no Júri: um envolvendo jurados - "cidadãos de notória idoneidade" que se transformam em juízes - e outro referente a réus — cidadãos sob suspeita que podem ou não sair dos plenários reincorporados à sociedade. Através dos vários procedimentos que compõem tais ritos, jurados e réus experimentam um poder que apresenta-se como supremo, uma vez que, acima dele, na esfera humana, não há outro, tanto que a própria lei assegura a soberania das decisões do Júri.

Enfim, os plenários, como microcosmos em que se reúne o que na sociedade está disperso, permitem um confronto agonístico, lúdico, ritualístico e melodramático de universos de representações, de práticas e de valores, segundo regras sócio-jurídicas que permitem decidir quem pode e até deve morrer, seja física - vítimas - ou simbolicamente - réus condenados.

\section{- Etiqueta do e no Júri}

Concluir que aquilo que mais se discute no Júri não é a adequação ou inadequação técnica e legal de um comportamento ao previsto em lei, mas uma escala de valores sociais que regula limites entre assassinatos socialmente suportáveis e insuportáveis, significa afirmar, em outras palavras, que, nos plenários, é encenada uma etiqueta da vida social.

Segundo Renato Janine Ribeiro, a palavra etiqueta significa, originalmente, rótulo, ou seja, algo que resulta de um "procedimento de nominação", do estabelecimento de sinais de diferenciação social e política que decorrem de um conjunto de regras e atitudes 
a elas correspondentes (Ribeiro, 1983 e 1994: 33-34). Nesse sentido, os "truques" da etiqueta real, à época de Luís XIV, “(...) visavam, justamente, a impressionar as mentes, a calar a dissidência, (...)" - (Ribeiro, 1994: 32) —, tanto que foi o próprio Luís XIV quem escreveu: "os povos sobre os quais reinamos, incapazes de penetrar o fundo das coisas, costumam regular 0 seu juízo pelas aparências que vêem, e (...) medem seu respeito e obediência segundo as precedências e as posições". Em outras palavras, o governante, ao valer-se de uma teatralização do poder, ou seja, de modos elegantes e respeitosos para sinalizar e instrumentalizar diferenças sociais e políticas, marca sua superioridade e distingue-se de seus membros (idem: 32-34).

Guardadas as devidas proporções, podemos afirmar que algumas opiniões de juízes, promotores e defensores a respeito de jurados podem ser interpretadas à luz do referido texto de Luís XIV, pois apontam-nos enquanto representantes de um público de súditos sobre o qual é preciso reinar. Um defensor, por exemplo, sugeriu, de certa forma, serem os jurados incapazes de "penetrar o fundo das coisas", ao declarar, em plenário: "Os crimes de homicídio são julgados por pessoas do povo porque, apesar de não serem juristas nem filósofos e de, portanto, não terem uma compreensão profunda de todos os detalhes envolvidos, são capazes de analisar questões do dia-a-dia, como xingamentos de que oréu foi vítima e a ira que isso pode deflagrar no homem médio." 25

Outras opiniões, mais taxativas e, geralmente de contrários ao Júri, revelam uma percepção dos jurados enquanto pessoas que regulam seu juízo pelas aparências e medem seu respeito e obediência segundo precedências e posições, conforme declaroume um juiz: "Não entendo a lógica do Júri, a razão de se entregar nas mãos de leigos justamente - julgamento dos crimes mais graves. Eles não têm condições para assumir essa responsabilidade, pois a maioria deles se deixa impressionar pelo melhor discurso, pela postura mais firme, seja a do promotor ou a do defensor e até pelo jeito do réu olhá-los e dos familiares do réu se comportarem. As regras do Júri, dentre outras coisas, mostram a cada um o seu lugar. No caso dos jurados, tentase inclusive protegê-los dessas influências." (grifo meu) ${ }^{26}$

Um risco, portanto, que a etiqueta do Júri oferece à própria instituição, caso ela se torne um fim em si mesma e não um meio para estabelecer e manter o status dos "governantes", é o de reduzir jurados-cidadãos a um público-passivo, ou a meros reiteradores de decisões tomadas por "sábios" juízes, promotores e defensores. Isso pode reduzir o caráter público das sentenças e o vínculo dessas com a res publica. "Em suma, quanto mais o governante fizer cena para sua popularidade, menos republicano ele será, e maior

\footnotetext{
$\overline{25}$ - 18/03/1999, das 13h40' às $17 \mathrm{~h}$, plenário II do $3^{\circ}$ Tribunal do Júri (Santo Amaro).

26 - entrevista de um juiz do $1^{\circ}$ Tribunal do Júri (18/07/2001).
} 
risco correremos de que, esquecendo o público pelo publicitário, ele se aproprie da coisa comum para fins privados."(Ribeiro, 1994: 34).

O depoimento de um juiz sobre os motivos "duvidosos" da impugnação de algumas sessões de Júri é uma reflexão a esse respeito: "O Júri é uma instituição muito complexa, pois nos plenários, não bastassem os crimes de morte em julgamento, lá estão representantes de instituições, como a Magistratura, o Ministério Público, a Procuradoria do Estado e a OAB. Entre si, eles guardam reservas e tensões. E sabe o que eu acho? Que juízes, promotores e procuradores ganham bastante bem para, por razões de vaidade, instigarem a dissolução de Júris. Imagine quantas pessoas são mobilizadas num Júri! E quantas o foram desde a lavratura do B.O! Quanto dinheiro público! São muitos esforços para desfechos frustrados." ${ }^{27}$.

Outro risco ou problema enfrentado pelo "teatro da política", em geral, e pelo teatro do Júri, em particular, é o de que os recursos cênicos utilizados por seus atores distanciem-se, cada vez mais, daqueles que fazem sucesso nas artes cênicas. A teatralidade da maioria dos juízes, promotores e defensores do Júri, assim como a de muitos políticos, tende a ser pesada, séria, baseada em expressões grandiloqüentes e gestos enfáticos que tentam expressar uma intimidade grandiosa - recursos típicos do teatro do século XIX. Como resultado desse tipo de teatralidade, os atores soam empertigados e rígidos em sua togas ou ternos e gravatas, enquanto, nas artes cênicas atuais, tendem a prevalecer a descontração, a leveza e uma linguagem mais direta que também fala da intimidade, porém de forma não grandiosa, mas intimista, resultando daí uma impressão de espontaneidade. "Isso cria um problema para os políticos [e para os operadores do Júri, eu diria] : o teatro que fazem não conquista mais o público. Não convence, não atrai. Eles estão atrasados, em seu jogo cênico, pelo menos três ou quatro décadas. (...) em nosso tempo a teatralidade dos políticos já não conquista as multidões (...) soa falsa” (Ribeiro: 2001).

Um dos mais renomados e antigos advogados do Júri, no Brasil, Evandro Lins e Silva, faz afirmações que revelam sua clareza a esse respeito. Citando Henri Robert, comenta: “(...) o foro sofreu outrora, no período romântico, o contágio do patos grandiloqüente e lacrimejante da moda. Hoje, quem discursa no estilo teatral de antanho arrisca-se a cair no (...) ridículo. Quanto mais um advogado adquire experiência do tribunal e quanto maior for a sua reputação, mais se esforça por conformar-se com este modelo de sinceridade, concisão e elegante simplicidade. (...) É preciso querer convencer e não seduzir."(Silva, 1991: 21).

Pelo que pude observar ao longo do trabalho de campo, boa parte dos promotores e defensores que atua nos Júris de São Paulo mescla o "modelo teatral grandiloqüente e

\footnotetext{
$\overline{27}$ - entrevista de um juiz do $1^{0}$ Tribunal do Júri (18/07/2001).
} 
lacrimejante" com o "de sinceridade, concisão e elegante simplicidade". Suas togas e os cenários dos fóruns e plenários tendem a reforçar o primeiro, embora não os impeçam de agir de acordo com o segundo, principalmente nos intervalos das sessões, nos corredores e gabinetes. E, conforme apontou Lins e Silva, são justamente os profissionais mais jovens e inexperientes - e, provavelmente, mais inseguros - os que mais recorrem à grandiloqüência, cansando e não convencendo os jurados.

Em sessões em que pude observar promotores e defensores principiantes, especialmente atentei para os momentos em que os jurados demonstravam sentir enfado. Normalmente, enquanto os arguidores, rígidos e empolados, recorriam a frases de impacto, nitidamente "estudadas" e carregadas de jargão técnico, o enfado surgia, ao passo que, quando em linguagem simples e direta, detalhavam dramas pessoais do réu e/ou da vítima e apelavam para uma reflexão a respeito dos valores envolvidos, a atenção dos jurados ressurgia. Portanto, a descontração dos oradores somada ao interesse pelos dramas pessoais demonstraram-se recursos cênico-narrativos eficientes, pois capazes de retirar os jurados da sonolência e da apatia. “(...) nosso mundo, o mundo da comunicação de massas e do entertainment é fã da intimidade. (...). A intimidade virou mercadoria (...). Os Césares romanos davam, à plebe, pão e circo. (...) queremos saber os segredos de quem vive no circo. (...). Lágrimas em público e a referência à família são recursos fortes, que conquistam a simpatia dos espectadores, mas dos quais não se pode abusar. Quando se evidencia que constituem burla ou rotina, é como o cristal partido do provérbio, que não se recompõe". (Ribeiro: 2001)

Os "Césares do Júri" parecem saber que a revelação minuciosa da intimidade de personagens envolvidos nos crimes é um bom entertainment para jurados, estudantes e advogados da platéia, pois corresponde "aos segredos de quem vive no circo" ou, usando uma metáfora atual, corresponde aos segredos de quem vive no fogo cruzado do "bangbang" urbano. A "realidade" da "longínqua" periferia, normalmente associada a uma terra sem lei e sem cultura, parece encarnar-se no réu e em seus parentes, dando ao Júri um certo tom de reality shows, cujo desfecho será ali decidido, através de votos de espectadores seletos - jurados.

Cabe ressaltar que, pelo que pude perceber, o interesse de réus e vítimas por momentos dramáticos da narração de suas próprias intimidades é quase inversamente proporcional ao que jurados, estudantes e advogados da platéia demonstram ter. Em geral, dentre todos os presentes ao Júri, réus e familiares são os que mais permanecem apáticos. Talvez, isso se explique, dentre outras razões, porque eles sabem que, diferentemente dos demais, terminado o espetáculo, eles não irão "simplesmente" 
embora. Mesmo que as histórias em julgamento sejam muito imaginadas e construídas, o seu desfecho terá uma aplicabilidade direta sobre a vida de réus e seus familiares. Eles sairão dali carregando esse desfecho.

Enfim, se há alguma regra geral sobre o que, no Júri, causa interesse a seus participantes, especialmente para os que se sentem "distantes" dos dramas narrados, é o fato de os discursos captarem tanto mais as atenções quanto mais descontraídos, diretos e não grandiloqüentes forem os oradores, especialmente se estiverem revelando "segredos" de gangues, do tráfico de drogas, de crimes passionais, de perseguições policiais em guetos e de tiroteios sangrentos.

Quanto à etiqueta do juiz que preside a sessão, alguns aspectos merecem ser retomados. Seu costumeiro entra-e-sai, durante o julgamento, e mesmo um certo ar "blasé", enquanto acompanha os debates, longe de apontarem descaso pela sessão, podem ser interpretados como uma demonstração de sua autonomia e poder. Há uma velada disputa cênica entre juiz, promotor e defensor pela protagonização do julgamento. Embora juízes abram e encerrem as sessões, interroguem os réus, passem a palavra aos defensores e acusadores, controlem o tempo das sustentações orais, sejam responsáveis pelo esclarecimento de dúvidas e encaminhamento de imprevistos, elaborem os quesitos a serem votados pelos jurados e coordenem as votações, sua posição soberana, frente às posições de promotores e defensores, é mais estática. Esses devem ser dinâmicos para serem olhados, ouvidos e convencerem o público. Portanto, o entra-e-sai e o ar "blasé" de muitos juízes talvez seja um modo de demonstrarem que são maestros do Júri. Justamente porque lhes cabe controlar a orquestra e porque dominam toda a partitura e a participação limitada e regrada de cada instrumentista, deixam-nos, às vezes, avançar aparentemente sozinhos. Ao fazerem isso, demonstram que são os únicos que desfrutam dessa liberdade e, por isso mesmo, estão acima dos demais.

Toda essa encenação constrói a legitimidade que atrai profissionais e leigos para o consenso de atribuição do poder em jogo e em cena no Júri, o qual, como qualquer poder que se pretende legítimo, não deve ser roubado ou usurpado, mas concedido. É na trama de identificações passionais do Júri que o poder de julgar é concedido por e para quem ali está. O Estado concede a leigos poder para julgar e esses, ao participarem do jogo, concedem ao Estado poder para que se imponha, soberanamente. Portanto, se, por um lado, a exibição da lei e da norma convence os leigos a participar do Júri, por outro, é através do processo de identificações passionais, estimulado por argumentos verossímeis 
de acusadores e defensores, que o Júri se torna socialmente legítimo. O que está em espetáculo é a norma da sociedade ou a etiqueta nela prevalecente.

\section{- Palco e platéia ou atores e público}

$\mathrm{Na}$ maioria das línguas e pensamentos atuais, "público" tem dois sentidos principais: um jurídico, oposto a privado, e que significa bem comum ou patrimônio coletivo; e outro teatral: “(...) a soma dos que assistem a uma representação, tendendo à passividade, podendo manifestar-se apenas pelo aplauso ou vaia (..), mas sem ter meios de reverter a radical e constitutiva desigualdade a separá-la dos atores. No sentido teatral, o público vale menos do que o palco. (Ribeiro, 1994: 32)

Seguindo o mesmo raciocínio, o verbo "representar" também pode ter esses dois sentidos: um jurídico, político e constitucional, que significa "ser representante de; e outro artístico, teatral e mediático, que significa fazer uma representação para; encenar para (idem).

A política moderna pode ser entendida, em boa medida, segundo alguns pensadores, pelo conflito entre esses dois sentidos, pois nela desenvolveu-se tanto uma esfera em que opiniões e votos decidem questões de interesse geral - sentido jurídico - quanto, conforme vimos no item anterior, desenvolveram-se regras de etiqueta responsáveis por manter os súditos devidamente separados do governante e reverentes a ele - sentido teatral ou "tecnologias de controle da sociedade" (Ribeiro, 1994: 32-33) ou ainda "tecnologia das aparências" (Balandier, 1982: 67).

No Júri, os dois sentidos de público e de representação também estão presentes e aparecem como conflitantes nos debates entre os favoráveis e contrários à instituição, uma vez que esses, dentre outros aspectos, discutem o quanto os jurados representam ou não os interesses sociais. Tentaremos demonstrar, contudo, que esses sentidos, no Júri, são mais complementares que conflitantes.

Por um lado, a lei, os discursos formais de operadores técnicos e mesmo a cenografia dos plenários tentam reiterar o caráter público-jurídico dos julgamentos. À portas necessariamente abertas, as sessões transcorrem para quem quiser assistir a elas. Além disso, nos plenários, os jurados leigos são incansavelmente apontados como representantes "da sociedade" e de seus principais valores e interesses, sendo o acusador, ou promotor público, aquele que também se autodenomina defensor de interesses sociais. 
Por outro lado, constantemente, o conjunto de operadores técnicos refere-se ao "público do Júri" como sendo formado pelos que se sentam na platéia para æssistir passivamente às sessões e, portanto, ficam simbolicamente e fisicamente separados dos demais - dos próprios operadores, de jurados e réus. Trata-se, portanto, de um público formado por estudantes, advogados, parentes e amigos de réus e/ou vítimas. Assim como ocorre em uma encenação tradicional, a peça pode transcorrer sem que esse público esteja presente.

Cabe, aqui, um breve comentário sobre a parcela desse "público" formada por estudantes de direito. Algumas vezes, sentei-me ao lado deles e li, discretamente, o que anotavam. Havia, basicamente, dados técnicos, como enquadramento do réu na denúncia e na pronuncia; frases soltas e não literais das sustentações orais do Ministério Público e da defesa, além do resultado da sentença. Não percebi, em nenhuma ocasião, registros que transcendessem aspectos formais e jurídicos do ritual. Não posso afirmar que todos os estagiários, estudantes e profissionais do direito limitem-se a tais anotações, mas não seria de espantar que assim agissem, pois embora percebam que há "algo mais" do que regras jurídicas em cena, não parecem ter consciência clara do que é esse "algo mais". Perguntei a um estudante, numa dessas ocasiões: ${ }^{28}$

$\Rightarrow$ Eu: Quais aspectos da sessão você acha os mais relevantes e anota?

$\Rightarrow$ Estudante: Tento anotar toda a seqüência prevista no CPP [Código de Processo Penal].

$\Rightarrow$ Eu: E dá prá anotar tudo?

$\Rightarrow$ Ele: Quase, pois é tudo muito regrado. Não tem como escapar.

$\Rightarrow$ Eu: Mas, se é tudo tão regrado e esperado, prá quê assistir às sessões, ao vivo? Não bastaria estudar bem o CPP?

$\Rightarrow$ Ele: Não! Não! De jeito nenhum! Aqui a gente aprende como as regras são aplicadas aos casos concretos.

$\Rightarrow \mathrm{Eu}:$ E como elas são aplicadas?

$\Rightarrow$ Ele: Ah! Depende do jeito de cada promotor, de cada advogado e de cada juiz.

$\Rightarrow$ Eu: $E$ você anota alguma coisa sobre esse jeito de cada um?

$\Rightarrow$ Ele: Não! Isso é muito de cada um, quer dizer, têm uns que são feras, mas só dá prá ser um dia como eles depois de fazer muitos Júris. Antes disso, é preciso dominar o básico, as técnicas.

$\Rightarrow$ Eu: Mas não seria o caso de anotar o que faz com que uns sejam feras? O que você acha que os torna especialmente bons?

$\Rightarrow$ Ele [já meio irritado com a minha insistência]: Olha, não dá prá anotar esse tipo de coisa, porque tem a ver com o estilo, com a personalidade de cada um. E nem valeria a pena anotar, porque não daria prá imitar, entende. Não tem segredo: é preciso dominar a técnica e, depois, usá-la, com segurança, e do seu próprio jeito.

$\Rightarrow$ Eu [sentindo que, talvez, fosse a última pergunta possível]: Mas qual o melhor jeito de aplicar as técnicas do Júri, na sua opinião?

$\Rightarrow$ Ele [bem irritado]: Ah! Sei lá! Como eu já disse, isso cada um vai desenvolvendo. Tem que fazer prá aprender e, desculpe, mas eu preciso ir...

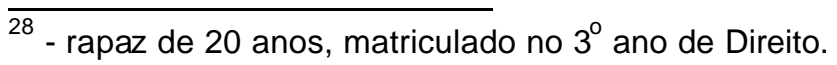


É de se notar que o estudante, apesar de afirmar que não bastaria estudar as regras do CPP, ou seja, que é imprescindível assistir às sessões para ver, "ao vivo", o "jeito" dos atores encenarem, escapa-Ihe que tal encenação também tem regras e lógica próprias. Ele percebe a importância da performance de cada ator como algo de caráter individual e não social, ou seja, ele não se dá conta de que as performances individuais subjazem a uma dinâmica teatral — e, consequentemente, social — do Júri.

Uma das decorrências desse tipo de percepção é a reprodução e a aplicação de um saber aparente só técnico que, por não ser entendido como integrado ao processo social que o engendra e do qual participa, faz com que seus operadores acreditem-se detentores de uma compreensão racional e imparcial dos conflitos sociais e das possibilidades de solucioná-los. Durante a graduação em direito, em disciplinas obrigatórias como Sociologia Geral e Jurídica, Filosofia Geral e Jurídica, Teoria Geral do Estado e Introdução ao Estudo do Direito, os professores costumam problematizar a construção e reprodução dos discursos técnico-competentes, mas tal problematização , normalmente, dilui-se em meio ao alto percentual de disciplinas estritamente técnicas ${ }^{29}$.

Voltando à gangorra entre os dois sentidos de público e de representação, pelo que pude perceber, assistindo às sessões de Júri, especialmente os jurados condensam, de forma peculiar, essa alternância pois, no sentido teatral, não estão na platéia e sim no palco, mas no sentido jurídico não estão no palco, pois não são propriamente atores, uma vez que assistem à representação, tendendo à passividade. Portanto, são tratados como "representantes da sociedade", mas lá estão para assistir a uma representação.

Ocupando, assim, uma espécie de camarote incrustado no palco, os jurados constituem uma platéia privilegiada, deixando de ser passivos somente nos bastidores -

\footnotetext{
29 - Desde 1990, leciono sociologia geral e jurídica em mais de um curso de graduação em direito. Essas disciplinas, geralmente, ocupam os primeiros dois semestres das grades curriculares, raramente ultrapassando o $4^{\circ}$. Isso significa que os estudantes têm contato com seus conteúdos programáticos numa fase introdutória e menos técnica do curso, perdendo-o, a medida que avançam e começam a estagiar. Boa parte dos estudantes, aliás, já vem do ensino médio com restrições à validade do estudo da sociologia num curso de direito, o que se reforça devido ao fato de muitas faculdades reservarem os piores horários da grade para essas disciplinas. Além disso, vários dos professores contratados para lecioná-las não têm formação interdisciplinar que thes permite um bom trânsito entre as ciências sociais e o direito, o que torna suas aulas ou mais apropriadas para alunos de ciências sociais ou mais para técnicos do direito. Num estudo de caso intitulado Sugestão de Novo Projeto Curricular e Pedagógico para a Faculdade de Direito de São Bernardo do Campo - São Bernardo do Campo, 2001 (475 pg. - 2 vol.) — analiso a viabilidade de mudanças estruturais num curso de graduação em direito, frente às atuais demandas de seus corpos discente, docente, ex-alunos, empregadores desses, do MEC e da Secretaria Estadual da Educação.
} 
sala secreta - onde, todavia, só podem manifestar-se através de mudos aplausos ou vaias, ao votarem sim ou não para cada quesito previamente formulado pelo juiz.

Formalmente, todavia, juízes, promotores e advogados ressaltam os jurados, especialmente no início e no final das sessões, enquanto "representantes da sociedade". Mesmo quando, também formalmente, descrevem a heterogeneidade social e apontam os jurados enquanto parcelas desse conjunto heterogêneo, impõe-se a idéia de que ali estão para garantir interesses públicos, não particulares ou de classe. Eis a fala de um promotor ao iniciar sua sustentação oral em plenário: "Senhores jurados, tudo que é feito num processo é para ser examinado pelos senhores que, na verdade, não são pessoas comuns, embora escolhidos dentre membros da sociedade para representá-la. (...). Os senhores representam parcelas da sociedade - segmentos profissionais, locais. Estão aqui para aplicar a justiça em nome da sociedade." $\mathrm{E}$ ao concluir sua sustentação oral, esse promotor reitera: "Os senhores são aplicadores da lei, que é a única forma de manter a vida em sociedade. Não são algozes, mas defensores da sociedade. Em nome dela, peço que condenem o réu" 30.

Nessa mesma linha, explicitaram alguns advogados de defesa, em plenário: "Jurados são representantes da comunidade. Na origem secular do Júri - leitura da pauta em praça pública - a comunidade julgava acusados de violar as leis. (...) É um serviço gratuito porque é uma relevante missão social.",31. "Os senhores jurados, ao estarem aqui, estão exercendo seu direito de cidadania, pois podem expressar, ainda que indiretamente, os reclamos de nossa sociedade.,32

Portanto, os jurados são tidos tanto como representantes do povo - o que legitima jurídica e politicamente o Júri - quanto como sendo o povo para quem promotores e advogados representam. "O júri é o meu público", declarou Evandro Lins e Silva, em entrevista ao Jornal do Brasil, ao mencionar que era para os jurados que montava seu teatro (Lemos, 1998: 26). Mesmo que isso possa ser interpretado como um conflito entre os dois sentidos de público, no Júri é exatamente essa dubiedade imprime a dinâmica e a legitimidade da instituição.

\footnotetext{
30 - idem.

31 - 19/07/2001, das $12 \mathrm{~h}$ às $17 \mathrm{~h}$, plenário 8 do $1^{\mathrm{O}}$ Tribunal do Júri (Barra Funda).

32 - 16/08/2001, das 09h às 11h40', plenário 7 do $1^{\circ}$ Tribunal do Júri (Barra Funda).
} 


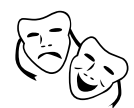

Uma das afirmações centrais desta tese, portanto, é a de que nos processos de competência do Tribunal do Júri, o desfecho condenatório ou absolutório depende mais do que se desenvolve durante algumas horas, nos plenários, do que daquilo que se processa, ao longo de anos, do primeiro registro policial do crime - início do fluxograma — até a contrariedade ao libelo acusatório. ${ }^{33}$

Embora a lei seja elaborada com base na crença de que a "verdade real" dos fatos deva aparecer, no modelo teatral do Júri, tal verdade revela-se verossímil e, por isso, o crime é menos discutido enquanto acontecimento legal e mais "apresentado enquanto representação" de fatos da vida cotidiana.

Nos julgamentos pelo Júri, portanto, há algo determinante, não passível de ser contido, transmitido e registrado em palavras escritas - por mais bem escritas que sejam - porque se trata de algo teatral, cuja intensidade só se dá e só pode ser percebida em cena, no transcorrer das sessões. Esse "algo", que o estudante de direito percebeu, mas não entendeu enquanto expressão culturalmente organizada, é o que tentamos descrever neste capítulo e, em última análise, é a razão de ser desta tese.

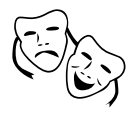

$\overline{33}$ - Ver o Fluxograma para processamento dos crimes de competência do Tribunal do Júri, no Anexo 4. 


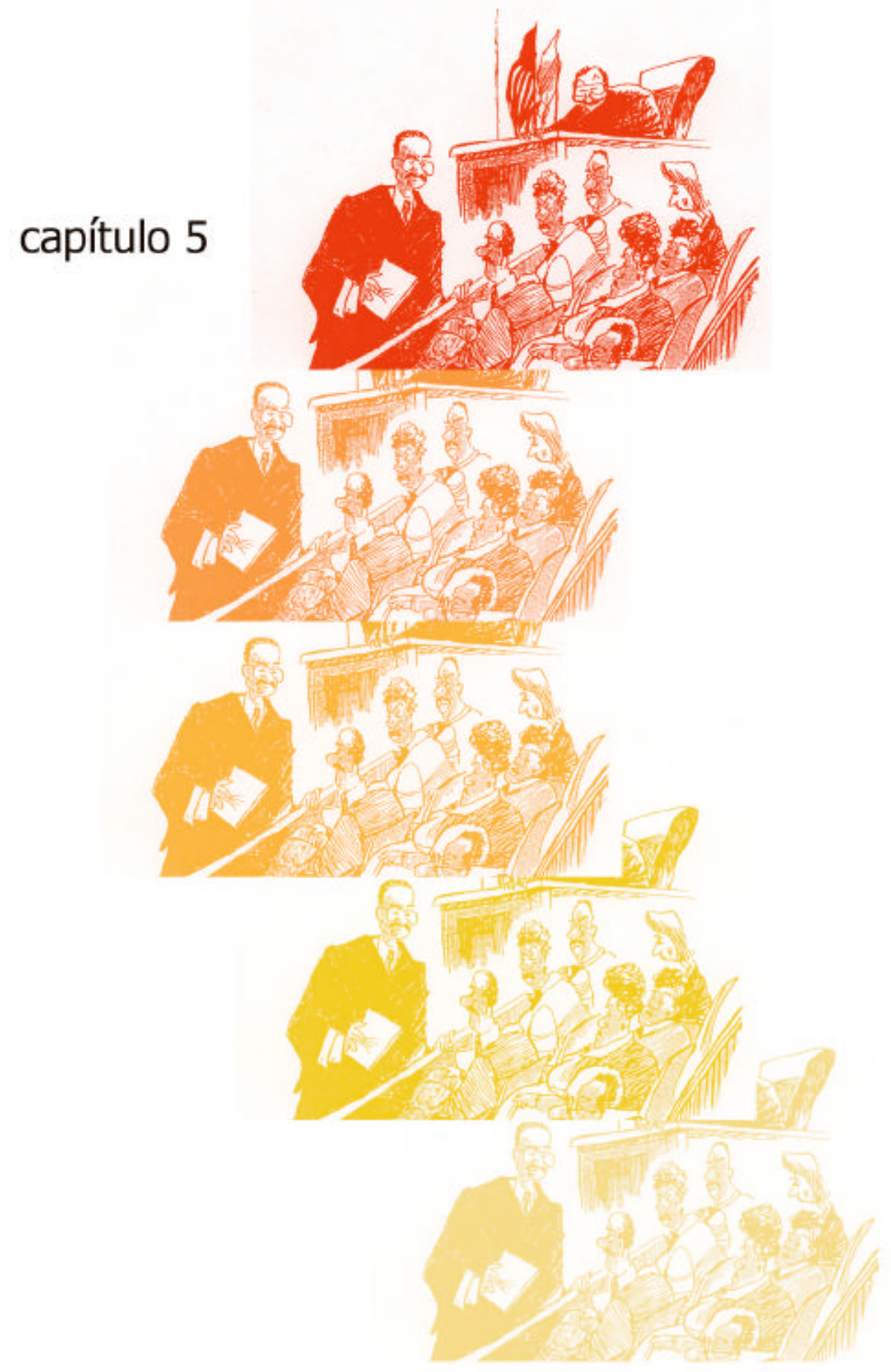




\section{UMA LEITURA ANTROPOLÓGICA DO TRIBUNAL DO JÚRI}

\section{- Introdução}

Como registrar "o clima" de uma sessão de Júri? Como traduzir em palavras o que nelas parece não caber e, por isso mesmo, expressase através de olhares que se procuram e se evitam, de sutis movimentos de lábios, sobrancelhas que se arqueiam e se franzem, mãos que se esfregam, dedos que tamborilam, ombros que se curvam e se erguem, corpos que caminham, acomodam-se em cadeiras ou permanecem estáticos, tudo isso em interação ininterrupta com o ambiente? Como anotar entonações de voz interligadas a uma gestualidade que, por sua vez, relaciona-se a um texto e a um contexto de contínua troca de mensagens? Enfim, como registrar o que, como diria Lévi-Strauss, os homens, habitualmente, não pensam em fixar na pedra ou no papel?

Clifford Geertz levantou semelhantes questões ao estudar as brigas de galos balinesas e ao tentar descrever a "dinâmica precisa do movimento de apostas" - as quais constituem, segundo ele, o aspecto mais intrigante das lutas, mais complicado e, "dadas as condições agitadas em que ocorrem, mais difícil de estudar". Sua conclusão foi a de que "Seria necessário, talvez, registrar a situação através de filmes, com múltiplos observadores, para ter uma noção precisa". Como não fez isso, considerou seu trabalho uma "abordagem impressionista"de um "etnógrafo solitário" (Geertz, 1978: 295, nota de rodapé $\mathrm{n}^{\circ}{ }^{15}$ ).

Jean Rouch, em 1953, uma semana antes de entregar sua tese, na Sorbonne, perguntou a seu orientador, Marcel Griaule, o que ele achara de seu texto. Griaule devolveu-lhe a pergunta, pedindo-lhe que fizesse uma autocrítica. Rouch, então, apontou qual era, na sua opinião, um dos pontos fracos da tese e propôs -se a melhorá-lo, exibindo filmes que ele próprio fizera, quando da realização do trabalho de campo. Tratava-se de imagens e sons que, como o próprio Rouch reafirmou, em outras oportunidades, registravam o que seria impossível descrever no papel e até mesmo em fotografia. Griaule, contudo, apesar de também fazer cinema, desaconselhou Rouch de tal ousadia, pois, à época, segundo o próprio Griaule, o cinema, na Sorbonne, "era o diabo".1

Passado quase meio século, temos a Antropologia Visual ganhando cada vez mais espaço na academia e fora dela, o que não significa que os desafios relativos à elaboração de etnografias estejam superados, especialmente o paradoxo de que grafar

\footnotetext{
1 - esse relato está no vídeo Jean Rouch - subvertendo fronteiras, de Ana Lúcia Ferraz, Edgar Teodoro da Cunha, Paula Morgado e Renato Sztutman, 2000, $41 \mathrm{~min}$.
} 
culturas - em palavras, imagens e/ou sons - é simultaneamente contribuir para que sejam conhecidas e simplificadas.

Várias vezes, pensei no quanto seria enriquecedor trabalhar a dinâmica das sessões de Júri através de registros audiovisuais e plurais, com imagens e sons advindos da perspectiva de réus, juízes, jurados, acusadores, defensores, assistentes, policiais militares, funcionários do Tribunal, como se uma câmera estivesse nas mãos de cada um deles, outra presa ao teto e outras tantas na platéia captando, simultaneamente e em close, diversos modos de participar de uma mesma situação.

Da primeira à última sessão a que assisti, ficou-me claro que, enquanto eu percebia determinados detalhes perdia outros e que, quando tentava acompanhar o conjunto, não era possível registrar os pormenores. Com o passar dos meses, reaprendi uma lição básica - e difícil - de metodologia de pesquisa "anti-positivista": focalizar um objeto e nele destacar o que interessa a um determinado recorte analítico é construir esse objeto. Seus limites, portanto, não são seus, mas os de quem o observa, competindo, portanto, ao observador, refletir sobre sua observação.

Em razão disso, cabe-me esclarecer que, nesta tese, denomino de "etnografia de sessões de Júri" o conjunto de impressões, observações e registros por mim acumulados ao longo de quatro anos de visitas aos Tribunais de São Paulo (1997, 1998, 1999 e 2001). Como, em momento algum, foi-me possível produzir registros audiovisuais dos julgamentos, pois não era e não é permitido a ninguém fotografar ou filmar o que se passa nos plenários ${ }^{2}$, restou-me, enquanto "etnógrafa solitária", fazer uma abordagem impressionista e escrita das sessões.

Tal abordagem implicou, na maioria das vezes, que eu, como assistente, acompanhasse os julgamentos registrando, à mão, o maior número possível de falas e expressões corporais dos participantes - operadores écnicos, funcionários e demais assistentes. Em algumas sessões, juízes que já me conheciam, convidaram-me para permanecer com os jurados, nos intervalos, na "sala de lanche" e, depois, para acompanhá-los à sala secreta, no momento da votação. Nesses dois tipos de oportunidades, jamais utilizei gravador, recurso do qual me vali apenas em entrevistas concedidas nos corredores, na lanchonete do Fórum, em gabinetes de juízes e promotores, na sala dos advogados ou por telefone. Portanto, majoritariamente, utilizei os tradicionais cadernos de campo, traduzindo em palavras e, às vezes, em croquis,

2 - excepcionalmente, por decisão do juiz que preside uma sessão, ela pode ser audio-registrada, pelo próprio Tribunal, para fins de posterior transcrição. 
impressões complexas, difíceis de elaborar rapidamente, tanto que, após muitas sessões e entrevistas, eu permanecia, em algum canto do Fórum, desenvolvendo observações cifradas.

Apesar dessas limitações de registro, uma das vantagens oferecidas por meu objeto de estudo, principalmente em relação aos de outros colegas que etnografam rituais esporádicos e/ou de grupos aos quais o acesso é difícil, é que, sempre que eu dispunha de uma manhã ou tarde — de $2^{a}$ à $6^{a}$ feira - e dirigia-me a um dos cinco Tribunais da cidade, especialmente ao $1^{\circ}$, no qual há vários plenários, lá estava o material social com que eu desejava trabalhar.

Neste capítulo, aprofundaremos, justamente, as principais características das sessões de Júri enquanto “(...) obras imaginativas construídas a partir de materiais sociais" (Geertz, 1978: 316-317), "estruturas simbólicas coletivamente organizadas que dizem alguma coisa sobre algo" (idem, 1978: 316-321) ou ainda "reuniões concentradas" (ibidem: 290)

Especificando alguns aspectos já desenvolvidos nos capítulos anteriores, exploraremos os julgamentos como textos literários que utilizam emoções para fins cognitivos", identificando tais emoções, a dinâmica de sua utilização e seus fins. E, para exemplificar a possibilidade e potencialidade dessa "análise semântica", leremos uma sessão, do começo ao fim, pois entendemos que “(...) se pode ler um ritual ou uma cidade, da mesma maneira como se pode ler um conto popular ou um texto filosófico. O método de exegese pode variar mas, em cada caso, a leitura é feita em busca do significado" (Darnton, 1986: XVI).

\section{- Aulas de educação sentimental}

Antes de "lermos" uma sessão, cabe pontuar que um aspecto a ser aprofundado numa análise semântica dos julgamentos pelo Júri é seu caráter pedagógico, pois assistir a eles ou deles participar é expor-se a uma espécie de educação sentimental (Geertz, 1978:317), uma vez que, nos plenários, de algum modo, todos tomam consciência do ethos que se apresenta ao grupo como dominante. Essa tomada de consciência e esse aprendizado a respeito de si mesmo e dos outros ocorre, especialmente, em situações como a de julgamentos, porque nelas a aparência desse ethos é soletrada externamente, num texto coletivo (idem).

No caso de sessões de Júri, os principais "soletradores", conforme já vimos, são o defensor e o acusador, pois em suas argüições, mais do que contar estórias para os jurados inocentarem ou condenarem o réu, eles contam histórias, para si próprios e para todos os presentes, a respeito de viver e morrer numa cidade como São Paulo. 
“(...), se vamos assistir a Macbeth para aprender de que maneira um homem se sente após ganhar um reino, mas perder sua alma, os balineses vão às brigas de galos para descobrir como se sente um homem (...) quando, depois de atacado, atormentado, desafiado, insultado e, em virtude disso, levado a paroxismos de fúria, atinge o triunfo total ou o nível mais baixo." (Geertz, 1978: 317-318).

Do mesmo, modo, podemos afirmar que quem assiste a uma sessão de Júri na cidade de São Paulo, de alguma maneira, lá "aprende" como se sentem homens e mulheres que, habitualmente, confinados no anonimato de bolsões de pobreza urbana, morrem e matam depois de atacados, atormentados, desafiados e insultados. Mas, diferentemente do que se passa num teatro, no Júri há espectadores que, além de assistirem à peça, são chamados a condenar ou absolver "Macbeths"de carne e osso, experimentando, portanto, "em ato", um "aprendizado teórico-prático".

Uma vez encerradas as sustentações orais — "peça-aula" — os jurados — "alunos-práticos" - são chamados a aplicar o que aprenderam, julgando e inclusive presenciando os primeiros efeitos de suas decisões. Ao optarem por uma das versões de que tomaram conhecimento, através das narrativas de defensores e promotores, produzem um conhecimento a respeito de como acusados e vítimas deveriam ter reagido num dado contexto emocional. Isso implica dizer que ao condenarem um réu, na maioria dos casos, fazem-no com base num conhecimento do que possivelmente ocorreu e produzem um conhecimento do que não deveria ocorrer. Em outras palavras, com suas sentenças, jurados avaliam o quanto certas emoções, em certos contextos, legitimam o desfecho morte. Essa legitimidade de circunstâncias emocionais é o que está em questão no Júri; é "a" questão do Júri.

Quem assiste às sessões da platéia, por sua vez, tem a chance de observar uma dupla aula de educação sentimental. Na primeira parte, arguidores expõem suas versões a respeito de como réus e vítimas sentiram-se e reagiram diante de certas emoções e, depois do intervalo, numa segunda parte, jurados ensinam, através de seus votos, que tipo de circunstâncias emocionais legitimam ou não homicídios.

Enfim, se vamos ao teatro para nos ver em cena, representados pelos atores, é porque neles nos projetamos e nos reconhecemos. Essas projeções e identificações colocam a todos no palco. Em muitas sessões de Júri, cada um dos assistentes, especialmente os jurados, à medida que ouvem e observam o desenrolar do julgamento, reconhecem ou não seus próprios valores articulados no discurso de um ou de vários "atores" - acusador, defensor, réu, juiz —, de modo que o resultado do julgamento é, 
nesse sentido, o resultado de um processo especular, geralmente sinuoso e indireto, porém inevitável. Como numa sala de espelhos, na qual quem se coloca diante deles vêse multiplicado ou mesmo transfigurado, estranhando-se ou reconhecendo-se, numa sessão de Júri temos as argüições absorvendo, multiplicando, transfigurando e refletindo valores dos participantes.

Embora pareça contraditório, quanto mais os casos em julgamento envolvem "gente da periferia" ou de "camadas populares", mais alguns jurados de "classe média" declaram-se seguros ao julgar. Conscientemente, eles justificam tal segurança com base numa imparcialidade ou "distanciamento crítico". Todavia, é possível pensar que as projeções e identificações mais profundas dêem-se, justamente, quando o outro é considerado estranho e "exótico" ou uma espécie de "avesso".

A própria história da Antropologia, em certa medida, ensina-nos o quanto resultou de complexas projeções o fato de os primeiros antropólogos identificarem nos "selvagens" o passado do homem branco e "civilizado" europeu. Julgar o aparentemente distante e até ficcional parece ser mais fácil do que julgar o aparentemente próximo e "real".

Perguntei, certa vez, a um jurado ${ }^{3}$ :

$\Rightarrow \mathrm{Eu}$ : Em algum momento, o Sr. se identificou com a ré ou com seu marido, quer dizer, colocou-se no lugar deles?

$\Rightarrow$ Jurado: Não, eles são muito dferentes de mim. Vivem noutra realidade, o que, aliás, me dá melhores condições de julgar. Mas acho que consegui imaginar o que a vítima sentiu.

$\Rightarrow \mathrm{Eu}: O$ Sr. acha que a realidade da vítima é mais parecida com a sua do que a do réu?

$\Rightarrow$ Jurado: Não! Não. Eu rão diria isso, quer dizer... O que eu acho é que, pelo visto, a vítima, como a maioria dos genros, tem sempre muitos defeitos aos olhos dos sogros, ainda mais das sogras. Afinal, não é a toa que falam tanto mal delas. Uma sogra, quando o casamento da filha vai mal, sempre acha que a culpa é do genro. Que ele é que é um mau caráter. Essa história não muda, sabe? Quer dizer, não é que minha sogra queira me matar e que todas as sogras queiram matar seus genros, mas essa sogra que nós julgamos hoje, representa muitas que andam por aí. Ar humilde, inofensivo, mas, por baixo, são verdadeiras feras, capazes de mandar matar os genros pagando os assassinos com uma TV. (grifos meus).

Julgar a sogra que mandou matar o genro no Jardim Órion e mesmo julgar "as sogras", em geral, talvez seja mais fácil do que julgar a própria sogra, tanto que esse jurado se exclui da regra de ter uma sogra que o persegue. Mas é muito provável que ao julgar a "sogra-Órion", sem dar-se conta, ele identifique-se com o "genro-Orion".

As impressões de jurados a respeito da vida, assim como as de todos nós, são colhidas assistematicamente, a partir das mais diversas situações cotidianas e,

$\overline{3}$ - entrevista concedida após o julgamento ocorrido em 19/07/2001, das $\pm 12 \mathrm{~h}$ às $\pm 16 \mathrm{~h} 30^{\prime}$, no Plenário 8 do $1^{\circ}$ Tribunal do Júri (Barra Funda). 
geralmente, permanecem, a maior parte do tempo, frouxas e desorganizadas. Situações como a de um julgamento pelo Júri coordenam e permitem focalizar parte dessas impressões, revelando-as, a nós mesmos, através dos sentimentos que em nós despertam e das reações que nos fazem ter.

O Júri, portanto, conforme já apontamos nos capítulos anteriores, põe em foco experiências da vida cotidiana, o que significa dizer que, ao mesmo tempo em que elas são colocadas à parte do cotidiano - como num jogo ou num ritual - elas religam -se a ele porque são interpretadas como acontecimentos humanos paradigmáticos. E, em geral, essas "experiências reveladoras" abordam menos o que acontece e mais o que gostaríamos que acontecesse (Geertz, 1978: 318).

"Encenada e reencenada, (...) a briga de galos permite ao balinês, como a nós mesmos, ler e reler $\mathcal{M a c b e t h}$, verificar a dimensão de sua própria subjetividade. (...) essa subjetividade não existe propriamente até que seja organizada dessa forma (...). Quartetos, naturezas mortas e brigas de galos não são meros reflexos de uma sensibilidade preexistente e representada analogicamente: eles são agentes positivos na criação e manutenção de tal sensibilidade" (idem: 319).

Parece correto, seguindo essa linha de pensamento, afirmarmos que ao serem encenadas e reencenadas, as sessões de Júri permitem a seus participantes ler e reler 0 quanto - e quando - é legítimo ou ilegítimo um ser humano matar outro. Quem assiste a um julgamento vê-se compelido a adequar a dimensão de sua própria subjetividade às mortes violentas narradas nos plenários. Assim como no caso da briga de galos balinesa, essas subjetividades só passam a existir ao serem organizadas. As sessões de julgamento, portanto, permitem tal organização à medida que criam e formatam uma sensibilidade a respeito da legitimidade ou ilegitimidade de mortes violentas.

Cabe ainda acrescentar que nessas "aulas de educação sentimental", predomina, por parte dos "professores", o uso de uma linguagem mais audiovisual que cinestésica, ou seja, prevalece uma linguagem que exige dos "alunos" uma especial atenção de seus olhos e ouvidos, ao contrário do que ocorre na briga de galos, nas quais os balineses, segundo Geertz, seguem o desenrolar da briga basicamente com o corpo. Isso não significa que os corpos de jurados e dos demais espectadores de Júris não "falem" e não acompanhem as expressões corporais uns dos outros. Mas, especialmente "alunosjurados", em todos os plenários observados, ficam de tal forma posicionados que, antes de tudo - e de um "ponto de vista" privilegiado - são chamados a se expor a olhares, ao mesmo tempo que devem olhar performances alheias. 
Mesmo no único momento em que jurados tornam-se "professores" — professam seus votos - a questão do que deve ou não ser visto é predominante. Ao retirarem-se para a sala secreta, ficam longe dos olhares da platéia e, na própria sala, não podem mostrar o que estão sentindo e pensando. Nesse "esconde-esconde", há inversamente uma valorização do que pode ser captado pelo olhar e pelos ouvidos.

Nos Tribunais do Júri, portanto, valoriza-se mais o que se vê e o que se ouve do que aquilo que toca a outros sentidos, até porque esses, em grande parte, são pouco culturalmente estimulados e desenvolvidos ${ }^{4}$. De vários ângulos, consequentemente, podemos considerar o que se passa nos plenários como aulas de educação sentimental "audiovisuais".

\section{- Reunião concentrada}

Nas brigas de galo balinesas, o árbitro é um cidadão excepcionalmente bem acreditado. "Semelhante a um juiz, um rei, um sacerdote e um policial, ele combina todas essas qualificações, e é sob a segurança de sua direção que a paixão animal da luta prossegue com a garantia cívica da lei." (Geertz, 1978: 290)

Retomando a idéia de que juiz, jurados, promotor e defensor dividem a posição de "príncipes", pois têm poder e revestem-se de poder, cabe, novamente, apontarmos que é o juiz togado, no Júri, quem se destaca como "cidadão acima de qualquer suspeita" e, por isso mesmo, é visto como garantia da possibilidade de que o julgamento desenvolva-se até o final. "Não fosse o juiz — declarou-me, certa vez, um jurado ${ }^{5}$ - eu acho que alguns Júris terminariam em pancadaria, porque, apesar da gente saber que o promotor e o advogado estão lá cumprindo seu dever e de que eles, depois, vão até andar de braço dado no corredor, eu acho que, têm horas, em que eles ficam com raiva um do outro e, que se o juiz não estivesse lá prá garantir a ordem, iria tudo prás cucuias. O juiz, em cada Júri, não tem nada a perder, mas os outros têm. Quer dizer, o juiz só perde se ele não controlar a coisa."

A "coisa" a que esse jurado referese, provavelmente, é menos o conjunto de regras que regulam o desenrolar das sessões e mais as paixões em jogo ou, como o próprio jurado apontou, é aquilo que cada um tem a perder: fama, auto-estima, futuros clientes, casos importantes etc. Portanto, como fato cultural ou entidade sociológica, o Júri ordena e aperfeiçoa paixões que mobilizam os contendores e, assim como procedeu

\footnotetext{
${ }^{4}$ - Sobre a característica fortemente audiovisual das civilizações ditas "modernas" e o abandono de outros sentidos, como o olfato, V. CORBIN, Alain - Saberes e odores: o olfato e o imaginário social nos séculos XVIII e XIX. São Paulo: Companhia das Letras, 1987.

5 - entrevista concedida em 05/03/1999, no $2^{\circ}$ Tribunal do Júri (Jabaquara).
} 
Geertz em relação à briga de galos, podemos considerar o Júri, nas palavras de Erving Goffman, uma reunião concentrada (Geertz, 1978: 290).

Esse tipo de reunião é inconsistente para considerar-se o conjunto de seus participantes pertencentes a um grupo, porém é estruturado o bastante para que tais participantes sejam considerados apenas componentes de uma multidão. O que caracteriza esse encontro de pessoas é o fato de elas serem absorvidas num fluxo de atividade comum e relacionarem-se, umas às outras, em função desse fluxo. "Essas reuniões ocorrem e se dispersam, seus participantes são flutuantes, a atividade que as provoca é discreta - um processo particularizado que ocorre novamente, em vez de um processo contínuo que persiste. Essas reuniões assumem sua forma a partir da situação que as congrega, o local onde estão situadas, (...). Para cada situação o cenário é criado por ela mesma, em deliberações do júri, operações cirúrgicas (...), através de preocupações culturais - (...) - que não apenas especificam o enfoque, mas o colocam em primeiro plano, reunindo atores e dispondo o cenário." (idem: 291).

Explorando esse conceito, podemos afirmar que o "fluxo" de atividade comum que absorve os participantes do Júri, fazendo-os relacionarem-se entre si, é a própria organização e valoração de paixões que se opera nos plenários, diante de narrativas de homicídios. E se tivéssemos, ainda, de destacar o aspecto desse fluxo em torno do qual todos os outros reúnem-se e através do qual exercem sua força - o ápice da reunião concentrada -, poderíamos apontar os votos dos jurados como tendo esse poder aglutinador. Para eles confluem todos os embates desenvolvidos durante os julgamentos.

\section{- Etnógrafos, advogados e promotores: poetas?}

Se "(...) as forças culturais podem ser tratadas como textos, como obras imaginativas construídas a partir de materiais sociais" (Geertz, 1978: 316-317), sendo o etnógrafo alguém que mergulha nesses textos e, ao interpretá-los, constrói outros, podemos afirmar que etnografar sessões de Júri é penetrar no material social "textualizado" e contextualizado nos plenários de Júris. Como fazer isso?

Embora Geertz jamais tenha associado diretamente cultura à poesia e etnógrafos a poetas que interpretam e também criam poemas, segundo Steven Lubet ${ }^{6}$, a linguagem poética é a mais adequada à construção de narrativas eficientes em tribunais, especialmente quando os acontecimentos aos quais referem-se envolvem crimes. Partindo desse pressuposto, etnógrafos de sessões de Júri lidam com uma linguagem poética e, talvez,

\footnotetext{
6 - advogado e professor da Northwestern University, EUA.
} 
também tenham de, em alguma medida, fazer uso dela, para transcrever o que etnografam.

Declarou Lubet, em entrevista telefônica a um jornalista: "Nossa obrigação é recriar o passado por meio de palavras. Mas o problema de nossa profissão é que o passado é algo irreproduzível. Como se recupera um crime que ocorreu há um ou dois anos? É impossível lembrar de todos os detalhes. Por isso, fazemos uma espécie de poesia." (Borges, 2001: 10).

Essa "recriação" do passado, do ausente, dos detalhes que escapam à lembrança é, em alguma medida, o que eu mesma percebia-me fazendo em relação à dinâmica dos julgamentos, pois logo após seu término, eu relia meus registros apressados para complementá-los com muitos detalhes que restavam-me gravados na memória. Certa vez, ainda no segundo de meus quatro anos de acompanhamento de Júris, após um julgamento muito longo - de, aproximadamente, 10 horas - fiquei muito insatisfeita com meus registros, dada minha incapacidade de, na hora, anotar "tudo" e de, depois, "recuperar" minúcias. Passados alguns dias, reli um texto de Carlo Ginzburg - "O inquisidor como antropólogo" - e tive um insight. Até aquele momento do campo, eu tentara registrar as sessões de Júri com a mesma "espantosa riqueza etnográfica dos julgamentos de Friuli [ltália, séculos XVI - XVII]. As palavras, os gestos, o corar súbito do rosto, até os silêncios - tudo era registrado com meticulosa precisão pelos escrivães do Santo Ofício" (Ginzburg, 1989: 209) e por mim...

"Confesso" - para usar um verbo bem ao gosto inquisitorial —, que assustei-me ao dar-me conta de que eu andara buscando, em pequenas pistas, "revelações de verdades etnográficas", como se essas pudessem ser mais neutras do que foram os documentos produzidos pelo Santo Ofício.

Se foi da "ânsia de verdade, por parte do inquisidor" - da verdade que lhe convinha - que resultou uma documentação extraordinariamente rica, apesar de deturpada pelas pressões psicológicas e físicas sofridas pelos acusados de feitiçaria, não resultaria minha etnografia e mesmo minha tese, com ricos detalhes e exemplos de peformances de seus participantes - dessa "ânsia" de eu alcançar uma verdade teórica e metodologicamente conveniente? Em que medida, assim como os inquisidores, não estava eu "extorquindo" das sessões, estereótipos que me interessavam?

Foi o próprio Ginzburg quem acalmou-me, ao apontar um caminho frutífero para esse questionamento. "A essência daquilo a que chamamos uma atitude antropológica (...) reside numa disposição dialógica", (op. cit.: 207), ou seja, no fato de antropólogos não deverem acomodar-se em procurar nos informantes meros ecos afirmativos para suas 
indagações - prática comum e, geralmente, bem sucedida entre inquisidores e acusados -, mas criarem situações em que vozes dissonantes e contraditórias não se "encaixam" em seus modelos e teorias.

A partir destas reflexões, ficou-me claro que era tão importante pensar nos "textos" produzidos pelos participantes do Júri como "apropriações" e "remodelações" que eles faziam do mundo, quanto no meu próprio texto como uma apropriação e remodelação de aspectos do ritual do Júri, especialmente interessantes à Antropologia.

Algo em meus registros, nos cadernos de campo, mudou, desde então. As sessões que antes eu anotava e imediatamente comentava, selecionando e conectando passagens às idéias de algum autor ou a algum dos pressupostos originais desta tese, passei a registrar de modo mais impressionista, ou seja, com menos direcionamento e, depois, considerando o resultado não sob o signo da falha ou do acerto, mas da significação de minha interação com o objeto de estudo.

Voltando a Lubet, comparei-me com os próprios arguidores do Júri e considerei que, se "As pessoas não conseguem entender as situações da vida sem tê-las convertidas em histórias"(Borges, 2001: 10) - e é isto o que fazem promotores e advogados nos tribunais —, talvez, algo de natureza semelhante fazemos nós, antropólogos, com nossas etnografias e teses a respeito de situações culturais complexas, difíceis de compreender, se não forem convertidas em "histórias".

Mas, enquanto advogados e promotores constróem narrativas nos tribunais a fim de transformar informações "desconectadas" de testemunhas, réus, provas etc em uma "história bem contada", permitindo que jurados cheguem a um veredicto, antropólogos não precisam construir suas narrativas etnográficas para transformar as mais diversas situações que observaram em uma "história bem contada" para seus leitores sentirem-se esclarecidos. Uma tese em Antropologia pode acrescentar dúvidas, polemizar, desconstruir "veredictos" ao invés de levar os leitores a eles.

Afirma Lubet que um bom advogado, ao contar a história de seu cliente, deve tomar cuidado para editar trechos que não comprovem o crime. "Suponhamos que um jovem está sendo julgado por um delito e que ele integra uma gangue de rua. Integrantes de uma gangue podem ser inocentes. Mas esse fato, certamente, criaria um preconceito enorme em torno do rapaz, caso fosse apresentado no julgamento. O advogado deve saber omitir." (Borges, 2001: 11).

A edição é considerada por Lubet um recurso legítimo, ao passo que, embora numa etnografia, ela também seja inevitável, seu fim não deve ser a omissão do que não 
convém ao antropólogo e à tese que deseja defender e sim , simultaneamente, um recurso e um objeto de reflexão.

Portanto, enquanto promotor e defensor, em plenário, normalmente, atribuem à multiplicidade e complexidade de fatores relacionados ao acontecimento social que se transformou em crime um "sentido" que lhes é conveniente, pois condizente com o formato jurídico de classificar o mundo, antropólogos não precisam reduzir a complexidade de seus objetos a modelos explicativos que condigam com um formato antropológico de classificar o mundo. É claro que, se etnografias e teses, em alguma medida, não levarem em conta o "formato" consensual na área, o trabalho sequer será aceito como antropológico. Portanto, o desafio é como, por exemplo, diante de julgamentos judiciais que fornecem ótimo material lúdico, ritual e dramatúrgico, por apresentarem conflitos humanos, não reduźllos a meras confirmações dos conceitos de jogo, ritual e drama, perdendo de vista as motivações humanas envolvidas nos conflitos, as quais, muito provavelmente, não "caibam”, perfeitamente, em lógicas explicações científicas.

Lubet, ainda tratando da produção de "verdades" nos tribunais, admite a inexistência de uma verdade absoluta. "Toda observação é influenciada por aspectos psicológicos. Duas pessoas podem dizer a verdade, mas descrever situações diferentes. (...), há um espaço enorme para interpretações e reconstruções distintas dos fatos. É aí que está a habilidade do advogado." (idem). Como exemplo, ele cita o caso de uma mãe texana que matou seus 5 filhos, afirmando que a discussão do crime não residiu no que ela fez, mas no por quê ela o fez. O promotor contou a história de uma "mulher-diabo' e a defesa falou da insanidade de uma mulher com 5 filhos. Para reduzir lacunas entre "verdades possíveis" dessa e de outras histórias, Lubet aponta a habilidade dos advogados de se questionarem, reciprocamente: "Isso fornece ao júri o cenário para se efetuar o julgamento correto." De certa forma, portanto, Lubet também valoriza uma postura dialógica entre os arguidores, embora afirme que o trabalho desses seja explicar histórias da forma mais favorável a seus interesses.

Sua opinião é a de que histórias construídas por promotores e advogados de defesa que seguem à risca cinco passos de um "roteiro básico e ideal" têm grandes chances de serem vencedoras e, quando os dois lados seguem esse roteiro à risca, têmse grandes julgamentos. Eis o roteiro:

1. explicar as razões para os atos do crime;

2. dissecar todos os fatos conhecidos;

3. dispor de testemunhas com credibilidade;

4. basear a história em detalhes precisos; 


\section{5. tornar a narrativa plausível.}

Enfim, talvez a grande diferença entre os discursos "vencedores" de antropólogos, promotores e advogados de Júri seja a de que, apesar de os primeiros não poderem isentar-se, por completo, de editar, etnograficamente, o que observam, não precisam induzir ninguém a convencer-se de sua versão. Um trabalho etnográfico, diferentemente de uma arguição jurídica, pode ser considerado bom valendo-se de uma certa icença poética que não o obrigue a omitir o inexplicável. Se a Antropologia trabalha com materiais sociais que são a base de obras imaginativas, não condizem com a grandeza desse objeto teses amarradas em camisas-de-força conceituais e, consequentemente, sem idiossincrasias, metáforas, jogo de palavras e, consequentemente, alguma poesia.

Diante dessa colocação, provavelmente meus colegas advogados, especialmente os mais preocupados com resultados "práticos" de esforços intelectuais, evocariam, "no mal sentido", o que Auden afirmou em sua elegia a Yeats: "A poesia nada faz acontecer, ela sobrevive no vale de suas palavras... na forma de acontecer, numa boca."

Geertz reconheceu exatamente isso em relação à briga de galos, ao concluir que nela os homens alegoricamente humilham-se, regozijam-se quando triunfam, mas não mudam de status. "A briga de galos só é "verdadeiramente real" para os galos - ela não mata ninguém, não castra ninguém, não reduz ninguém à condição de animal, não altera as relações hierárquicas entre as pessoas ou remodela a hierarquia; (...): ela assume (...) temas [e] (...) tornaos significativos - visíveis, tangíveis, apreensíveis - "reais" num sentido ideacional. Uma imagem, uma ficção, um modelo, uma metáfora, a briga de galos é um meio de expressão; sua função não é nem aliviar as paixões sociais nem exacerbá-las (embora, em sua forma de brincarcom-fogo ela faça um pouco de cada coisa), mas exibilas em meio às penas, ao sangue, às multidões e ao dinheiro. (Geertz, 1978: 311)

Assim também são as sessões de julgamento pelo Júri que, talvez, só sejam "verdadeiramente reais" para os réus que saem delas em liberdade ou para o sistema prisional. Somente eles mudam de status, pois elas não diminuem nem aumentam o número de mortes violentas que, diariamente, ocorrem na cidade, bem como não interferem, significativamente, na condução de debates passionais, políticos e legais sobre as circunstâncias envolvidas nessas mortes. A única coisa "real", no sentido de ideacional, nas sessões de Júri, é o principal tema que sustenta seu conteúdo dramático e metafórico: a legitimação ou não de mortes violentas de acordo com a aceitação ou não, pelos jurados, de certos valores e circunstâncias apresentadas. 
Como forma dramática, o Júri exibe uma estrutura atomística, pois cada sessão é quase um mundo em si mesmo. Entre os participantes, mal as sessões terminam, permanecem lembranças esquemáticas e difusas do que se passou durante as horas de plenário, pois, como qualquer forma expressiva, o Júri só tem vida plena em seu próprio presente, aquele que ele mesmo cria. (idem: 312-313)

Como metáfora, nas horas de Júri, reproduz-se a compreensão do desenrolar da vida como um fluxo - um movimento unidirecional que vem do passado e atravessa o presente em direção ao futuro - , ao contrário do que se passa com os balineses que, segundo Geertz, vivem "em jorros", como se a vida fosse uma pulsação que liga e desliga. A briga de galos "Não significa uma imitação da pontuação da vida social balinesa, nem uma representação dela, nem mesmo uma expressão dela - é um exemplo dela, cuidadosamente preparado." (ibidem: 313)

A percepção de temporalidade e vida dominantes em nossa sociedade é a de um desenrolar de acontecimentos que ganham sentido se organizados numa linearidade com começo, meio e fim. Daí, não ser por acaso que os processos judiciais "processam" informações em busca de sentidos que se expliquem e conectem cronologicamente, rumo a um desfecho. Desse ponto de vista, os julgamentos pelo júri são exemplos, "cuidadosamente preparados" dessa percepção de temporalidade e de vida.

Contudo, as sessões de Júri, assim como as brigas de galo balinesas, não só apresentam-se como uma reiteração de um modo de ser e de pensar predominante e cotidiano, como também contradizem-no e mesmo subvertem-no, revelando as coisas mais como os homens imaginam que deveriam ser do que como, de fato, são.

Enquanto a briga de galos, por um lado, evita o conflito aberto entre pessoas que ocupam diferentes posições hierárquicas, coerente com um "jeito balinês" predominantemente tímido, cauteloso, reprimido, controlado e arredio ao conflito aberto, por outro, ela é agressiva, talvez revelando como os balineses são em suas próprias imaginações: "a briga de galos se expressa com mais força sobre as relações de status, (...), é somente nas brigas de galos que os sentimentos sobre os quais repousa essa hierarquia se revelam em suas cores naturais. Envolvidos, nos outros lugares, numa névoa de etiqueta, uma nuvem espessa de eufemismo e cerimônia, de gestos e alusões, aqui eles se expressam sob o disfarce muito tênue de uma máscara animal, uma máscara que na verdade os revela muito mais do que os oculta." (op. cit: 314)

Nos plenários do Júri, o que normalmente ocorre, de forma tímida, discreta e reprimida, em diversas camadas de nossa sociedade, sob o rótulo de "fofocas", seja, ao pé do ouvido, seja em revistas e programas especializados nesse tipo de "revelações", 
ganha o poder de, nos processos judiciais, sob o rótulo de provas testemunhais e depoimentos, invadir e expor privacidades de modo ousado, levantando, confirmando ou refutando suspeitas. Nesse sentido, os julgamentos pelo Júri mais expressam do que escondem um gosto generalizado por julgarmos a vida alheia e, consequentemente, resolvermos, externamernte - no réu absolvido ou condenando - dilemas amorosos, familiares, de vizinhança, hierárquicos, econômicos etc que estão, inconclusos, dentro de nós.

Enquanto forma expressiva, portanto, o Júri atua desarrumando "contextos semânticos" que, normalmente, presentam-se como sedimentados e consensualmente aceitos, fornecendo, assim, um comentário metassocial sobre o tema matar em nome de certos valores aceitos como legítimos para justificar tal ato. A função do Júri é poética porque é interpretativa. É uma estória sobre nós que contamos a nós mesmos. (op. cit: 315-316).

\section{- Um exemplo de caso para pensar}

Se esta tese tivesse uma ênfase precipuamente metodológica, caberia descrever várias sessões para demonstrar, comparativamente, o quanto mudou, ao longo da pesquisa, meu modo de acompanhá-las, registrá-las e de, consequentemente, interpretálas. Contudo, apresentarei uma só sessão, cuja dinâmica básica representa a de várias outras - duração, tipo de embates discursivos, sem réus e/ou vítimas "famosos". Essa apresentação tem por objetivo demonstrar o tipo de registro mais "bruto" com que trabalhei, pois foi do conjunto de 107 registros semelhantes a esse que resultou esta tese. Numa dada altura da pesquisa de campo, eles passaram a significar algo que transcendia seus detalhes e sugeria possibilidades interpretativas.

É claro que, como em qualquer jogo, seqüências e pormenores de uma sessão dificilmente repetem-se em outra, a começar pela descrição do suposto contexto que envolveu réu e vítima. Além disso, é raro repetir-se a mesma composição de jurados em diferentes Conselhos de Sentença, sendo também bastante variáveis os trios formados por juiz, acusador e defensor. Enfim, normalmente mudam algumas das seqüências do jogo e carcaterísticas de certos jogadores, mas pouco ou nada variam as estratégias, as regras e as peças que estão no tabuleiro. 


\section{Caso "PROTETOR DO SOBRINHO"}

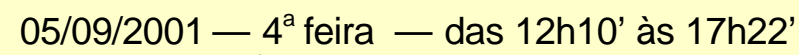

Plenário $9-1^{\circ}$ Tribunal do Júri - Barra Funda

Processo $n^{0}: 1.211 / 91$

\section{$\rightarrow$ Posição que ocupei nessa sessão}

- assistente.

- entrevistei apenas um dos defensores, durante o intervalo para almoço.

\section{$\rightarrow$ Observações iniciais}

- os funcionários do Fórum da Barra Funda entraram em greve em 27/08, de modo que esse processo só foi julgado porque vieram operadores técnicos e funcionários do $4^{\circ}$ Tribunal do Júri (Penha).

- o horário marcado para o início da sessão era 9h, mas houve atraso no transporte do réu preso.

- às $11 \mathrm{~h}$, vários jurados - sentados à esquerda do plenário, em relação a quem entra - bem como o juiz, o promotor, os defensores e outras pessoas sentadas à direita - ainda aguardavam a chegada do réu. Do lado de fora, quatro mulheres conversavam e pude identificar três delas como sendo a mãe, uma irmã, e a mulher do réu.

\section{$\rightarrow$ Réu}

- 11h50': entra em plenário, algemado. Já cumpre pena por roubo com cárcere privado das vítimas, condenação da qual está recorrendo. ${ }^{7}$

- negro, jovem, alto, bonito, magro, musculoso, cabeça raspada, camisa pólo branca e calça bege. Postura não altiva, tampouco submissa. Olhar triste, de quem tem mais lembranças do que expectativas.

- enquanto aguardava-se o retorno do promotor, o réu e seus advogados conversaram, detidamente.

\footnotetext{
7 - obtive esta informação do defensor, no intervalo para almoço, quando ele contourme ter convicção de que, no processo em julgamento, o réu seria absolvido por legítima defesa. Informoume, também, que no roubo pelo qual o réu fora anteriormente condenado, os comparsas haviam no obrigado a participar, sob ameaça de morte, tendo ele garantido o cárcere privado das vítimas, "sem agredi-las". O defensor informou-me, ainda, que atuava como advogado dativo no Júri de Santo Amaro e que este é seu primeiro Júri como defensor constituído, juntamente com sua mãe.
} 
- manteve-se cabisbaixo, do início ao término da sustentação oral da acusação, e assim permaneceu, mesmo durante a sustentação oral de seus defensores.

\section{$\rightarrow$ Início da sessão}

- 12h10': o juiz pede desculpas aos jurados, em nome próprio, do promotor e dos defensores, pelo atraso no início da sessão, reportando-se ao "problema crônico do ineficiente transporte de réus presos". Voz pausada, tranqüila; sempre ao microfone.

- antes do sorteio do Conselho de Sentença, cumprindo o previsto no art. 458 do CPP - Código de Processo Penal - , caput, o juiz advertiu os jurados dos principais impedimentos e incompatibilidades legais (art. 462) para participarem da sessão - algum tipo de parentesco com o juiz, o promotor, o advogado, o réu ou a vítima; jurados marido e mulher, ascendentes e descendentes, sogro(a) e genro/nora, irmãos, cunhados durante o cunhadio, tio(a) e sobrinho(a), padrasto ou madrastra e enteado(a). ${ }^{8}$

- ainda de acordo com o art. 458 do CPP, $\S 1^{\circ}$, o juiz advertiu os jurados de que, uma vez sorteados, não podiam comunicar-se entre si e/ou com outras pessoas, tampouco manifestar suas opiniões sobre o processo: "Os senhores devem manter uma posição semelhante à minha, de neutralidade. Não devem deixar transparecer emoções e opiniões. Os intervalos são como um "recreio", mas durante seu transcorrer não devem ser debatidos assuntos sobre criminalidade e segurança pública, mesmo que, aparentemente, não tenham a ver com o processo em julgamento. $O$ voto é secreto, portanto, um jurado não pode saber, nem ter motivs para desconfiar, qual o voto do outro."

\section{$\rightarrow$ Sorteio dos jurados}

- Eram 15 os presentes.

- os nomes e respectivas profissões dos 21 convocados estavam registrados numa folha da qual juiz, promotor e defesa tinham cópia, de modo que, no momento do sorteio, à medida que o juiz lia os nomes dos sorteados, primeiro a defesa e depois a acusação podiam, olhando para o(a) sorteado(a) e

\footnotetext{
8 - é extensa a jurisprudência relativa a casos de participação de jurados que, por terem entre si alguma relação de parentesco ou afinidade, ensejaram nulidade do julgamento (JESUS, 1989: 290-293). A lei ainda proíbe que o jur ado participe do julgamento se houver afinidade, relação de amizade/inimizade com as partes e/ou operadores técnicos, interesse profissional/pessoal ou
} 
conferindo sua profissão nessa folha, recusálo(a), sem explicitar o motivo. Cada um podia fazer isso por três vezes, depois do que é necessário motivar a recusa.

- Foram aceitos seis homens e uma mulher. Três das quatro mulheres sorteadas foram recusadas pelo promotor, de modo que, não fossem essas recusas, haveria no Conselho quatro homens e três mulheres. ${ }^{9}$

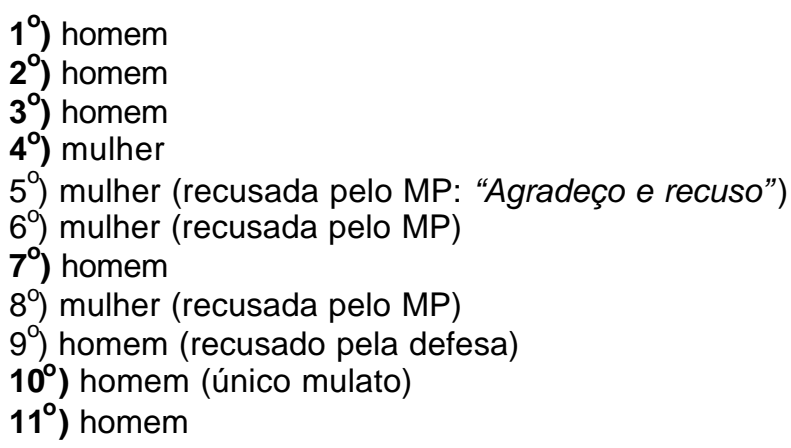

- à medida que cada jurado era sorteado e aceito, encaminhava-se para seu lugar no "palco".

- concluído o sorteio, antes de dispensar os não sorteados, o juiz esclareceu que os recusados não o foram por motivos relacionados a sua idoneidade, pois tais recusas são prerrogativas das partes, previstas em lei e, normalmente, ocorrem.

- aos jurados que compuseram o Conselho de Sentença, o juiz disse: "A partir de agora, os senhores passam a integrar o Poder Judiciário, na função de juízes".

- Anotei, em vermelho, em meu caderno de campo:

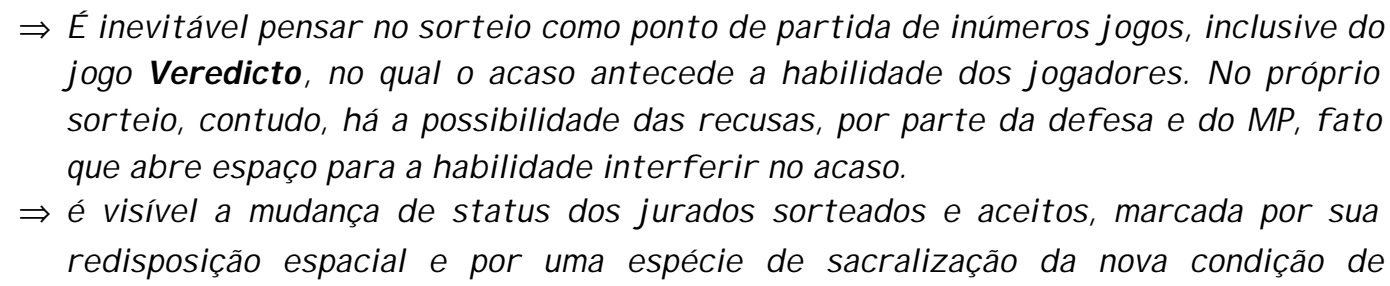

qualquer outra ligação com o caso em julgamento. Aplicam-se aos jurados as mesmas suspeições aplicáveis aos juízes togados (art. 252-256 - CPP).

9 - nesse julgamento, como na maioria dos 107 , não tive acesso às profissões dos jurados, mas, noutro dia, numa rápida entrevista, o promotor revelou-me: "Recusei-as por serem mulheres, mas não por ter algo contra mulheres juradas. É que, nesse caso, além do réu ser bonito, no momento do crime, ele estava acompanhado da irmã e da esposa. Havia uma trama familiar em jogo, envolvendo possível proteção do réu a seu sobrinho. Achei que juradas seriam mais condescendentes com ele do que jurados porque essas questões familiares, em geral, tocam mais as mulheres que os homens". 
integrantes do Poder Iudiciário. Ao entrarem no "palco", deixam a descontração da platéia e tornam-se circunspectos; sisudos; "incomunicáve is".

- em seguida, o juiz perguntou se havia algum "novato" entre os jurados e três levantaram as mãos. Didaticamente, então, explicou-Ihes que, para a devida instalação do Conselho, todos prestariam um termo de compromisso, numa breve solenidade, na qual cada um, ao ser chamado nominalmente, e após ouvir o termo, responderia em voz alta: "Assim o prometo".

- como na maioria das outras sessões às quais assisti, estando todos os presentes de pé, o juiz leu a exortação do art. 464 - CPP — "Em nome da lei, concito-vos a examinar com imparcialidade esta causa e proferir a vossa decisão de acordo com a vossa consciência e os ditames da justiça" - e, em seguida, nomeou cada um dos sete jurados para responderem: "Assim o prometo". Todos, entretanto, responderam "Assim eu prometo".

- Os jurados não sorteados e recusados foram, então, dispensados pelo juiz $12 \mathrm{~h} 20$ ' - com mais pedidos de desculpas pelo atraso e agradecimentos pelo comparecimento.

- antes de iniciar o interrogatório do réu, olhando para as quatro mulheres, parentes desse, presentes na "platéia", o juiz alertou "O público presente deve manter comportamento adequado, durante todo o julgamento, ou seja, os senhores não podem se manifestar nem entabular conversas paralelas, pois, caso isso ocorra, eu ordenarei o esvaziamento do plenário". As mulheres se entreolharam, com preocupação.

\section{$\rightarrow$ Interrogatório do acusado}

- Seguindo o script do CPP - art. 465 - o juiz presidente passou ao interrogatório do réu (12h25'), mas, antes, novamente em tom didático, explicou que era pertinente a leitura da denúncia para que os jurados se inteirassem da acusação.

\section{$\rightarrow$ Leitura da denúncia pelo juiz}

- 29/setembro/1991 - Praça Brasil - Itaquera - horário incerto. Nas proximidades de um bar, o réu, acompanhado de um indivíduo menor "A", montados numa motocicleta, provocam a morte de $M 1$ e tentam matar $M 2$, irmão de M1, mediante disparos de arma de fogo. M1 morreu com um tiro na 
testa e M2 sequer foi atingido. Pelo que consta dos autos, M1 teria ofendido o irmão do réu, razão por que esse foi-lhe tirar satisfações.

$\Rightarrow$ Juiz: O Sr. conhece o menor "A"?

$\Rightarrow$ Réu: Era meu sobrinho

$\Rightarrow$ Juiz: Era? Por que? Não está vivo?

$\Rightarrow$ Réu: Não, Sr. Morreu.

$\Rightarrow$ Juiz: Assassinado?

$\Rightarrow$ Réu: Assassinado.

$\Rightarrow$ Juiz (leu o nome completo da vítima fatal e depois da vítima da tentativa e, após mencionar cada um, perguntou ao réu se os conhecia).

$\Rightarrow$ Réu (balançou negativamente a cabeça, ao ouvir cada nome e completou): Não conheço nenhum dos dois, nem de vista.

$\Rightarrow$ Juiz (leu nomes das testemunhas de acusação e, um a um, perguntou se o réu as conhecia).

$\Rightarrow$ Réu: apenas reconheceu o nome de sua irmã.

$\Rightarrow$ Juiz: O Sr. tem inimizade com essa sua irmã?

$\Rightarrow$ Réu: Não, Sr. Vivo em harmonia com todos os meus irmãos.

$\Rightarrow$ Juiz: O Sr. cometeu os dois crimes de que é acusado, ou seja, matou M1 e tentou matar o irmão desse, M2?

$\Rightarrow$ Réu (após instantes de silêncio): Fui eu, sim que atirei na direção deles, mas prá defender meu sobrinho. Eu não tive intenção de matar ninguém.

$\Rightarrow$ Juiz: Defender seu sobrinho de quê?

$\Rightarrow$ Réu: Perguntou ao juiz se podia contar o que aconteceu naquele dia e, após autorização, narrou, de forma muito prolixa, que fora visitar sua mãe. Ao encontrá-la, soube que a casa de uma de suas irmãs havia sido invadida e que um de seus irmãos, "S", havia sido esfaqueado, sendo que os agressores ameaçavam matar seu sobrinho, filho desse irmão. Saiu, então, em companhia dessa irmã e de sua esposa à procura do sobrinho. Declarou que não conhecia os autores da agressão contra seu irmão o qual logo fora socorrido pelo cunhado. Numa praça, juntamente com sua irmã e esposa, aguardou o aparecimento de seu sobrinho, supondo que ele passaria por ali. Notaram que um grupo também estava no local e, quando o sobrinho apareceu, huve um tumulto. Em meio a esse, pegou o sobrinho, deu um tiro para o ar, mas, como os componentes do grupo que os ameaçavam não se afastaram - a vítima M1 portava uma faca - , atirou em direção a eles, "sem mirar ninguém." Depois disso, fugiu da praça com a irmã e a esposa. Seu sobrinho ficou para trás e nem sabe como saiu de lá. Somente no dia seguinte, soube que uma pessoa havia morrido. Acrescentou que, na ocasião, não podia correr, pois mancava, devido a um acidente de carro sofrido um ano antes.

- após ouvir essa versão do réu, o juiz folheou o processo, com ar de quem prosseguiria o interrogatório, mas finalizou-o, declarando-se "satisfeito" (12h42').

- o juiz leu o relatório do processo, conforme reza o art. 466 do CPP.

- nem o promotor, nem os defensores pediram a leitura de peças, em voz alta, a qual é possível, nesse momento.

- 12h45': o juiz suspendeu os trabalhos, por 45 minutos.

- imediatamente, fiz os seguintes comentários em meu caderno de campo: 
$\Rightarrow O$ discurso do réu foi relativamente bem articulado e ele estava calmo. A narrativa tornou-se confusa justamente quando referiu-se ao momento dos tiros.

\section{$\rightarrow$ Intervalo para almoço}

- na lanchonete, do térreo, dei-me conta de que sentia dificuldade em abordar as familiares do réu. Elas estavam lá, numa mesa próxima à minha, com ar triste, a mãe de mãos dadas com a filha. Não consegui interromper esse momento delas, mas ao ver um dos defensores, abordei-o e conversamos, por alguns minutos.

\section{$\rightarrow$ Sustentação oral do promotor}

- com voz mais ou menos baixa e falas rápidas, posicionou-se, a maior parte do tempo, entre os jurados e a divisória que os separava da "platéia". Em vários momentos, sentou-se nessa divisória, de costas, portanto, para a "platéia"

- 13h45': iniciou com os cumprimentos e saudações: "Exmo Sr. Presidente deste Tribunal do Júri, Dr. (...). Pelo 2 dia consecutivo, tenho a honra de trabalhar com Vossa Excelência, cuja segurança, simpatia e cordialidade conheço e admiro de várias outras sessões que compartilhamos. Aos defensores, embora desconheça-os, com certeza devem estar representando muito bem a OAB. O MP, portanto, saúda a OAB. Aos funcionários deste Tribunal, sem os quais as sessões não se processariam, aos PMs, bravos cidadãos que garantem a nossa segurança neste plenário e fora dele, a todos os presentes que nos brindam com sua atenção, os meus cumprimentos. Aos Senhores jurados, desde já, adianto que explicitarei os fatos da maneira mais simples e didática possível, pois coloco-me no lugar de Vossas Excelências e imagino como eu me sentiria sendo chamado a atuar, da noite para o dia, numa área profissional que não é a minha e da qual nada conheço. Sei que é difícil para leigos analisar um processo judicial e decidir. Respeito muito o que fazem."

- explicou, especialmente aos três jurados "novatos", que leria o libelo e que, sempre que lesse qualquer documento, citaria o número das folhas em que encontrava-se no processo para que os jurados, se quisessem, também acompanhassem a leitura.

- 13h54': usou uma espécie de lousa, próxima aos jurados, para esquematizar os dois crimes de que o réu era acusado. Escreveu:

\begin{tabular}{|l|l|l|}
\hline vítimas & resultado & enquadramento \\
\hline M1 & morte & homicídio simples, consumado; \\
\hline M2 & não atingido & tentativa de homicídio simples. \\
\hline
\end{tabular}


- considerou "nebuloso" o esfaqueamento de "S", irmão do acusado, no mesmo dia dos crimes em questão: "Não há provas de que a vítima fatal, M1, foi quem esfaqueou "S". M2, irmão de M1, nem consta como envolvido com "S"!

- sustentou a tese de que o menor "A", sobrinho do réu, estaria perseguindo os responsáveis pelo esfaqueamento de "S", pai desse, e que "o réu fez o que fez para proteger o sobrinho".

- "Muito, no Júri, vem da prova, da lei. Mas muito, também, vem do bom senso dos jurados. É essa uma qualidade que deles se espera”.(...) O Ministério Público pedirá a condenação do acusado porque a vítima morta sucumbiu com um tiro na cabeça. Logo, quem atira na direção da cabeça de outrem teve intenção de matá-lo (...). Não há nada que torne justo o que o réu fez.(...) Segundo o réu, que declara não ter tido intenção de matar as vítimas, alguém, portando uma faca, atacaria seu sobrinho. Preparem-se! A tese da defesa será a falta de ânimo do acusado para matar e, portanto, a alegação de que agiu em legítima defesa".

- leu o depoimento do sobrinho do réu (fls. 134), na fase judicial, na qual esse declarava que a vítima M1 portava uma faca para atacá-lo. Enfatizou: "Srs. jurados, o depoimento do sobrinho deve ser contextualizado, pois como ele foi protegido pelo tio, no dia dos fatos, pode tê-lo protegido ao depor em juízo."

- leu também o depoimento de M2 - vítima do homicídio tentado - e também considerou-o parcial, "pois é irmão da vítima fatal. (...) todos os depoimentos devem ser contextualizados, além do que, os depoimentos de familiares do réu e da vítima não fatal são contraditórios. Segundo os familiares, o réu agiu em legítima defesa e, segundo a vítima $M 2$, o réu e seu sobrinho agiram por vingança. (...) são provas formais, a serem apreciadas de modo a levar à prova substancial, a qual somente os jurados poderão avaliar".

- aproximando-se muito dos jurados e segurando o processo acima dos ombros disse: "Eu estudei horas e horas este processo, ao passo que os Srs. não o estudaram sequer um minuto, o que dificulta ainda mais o trabalho que devem desempenhar. Além do estudo, a prática também me faz concluir que a versão do réu é duvidosa."

- anotei, ao lado: Típico discurso competente!

- leu ainda o depoimento de uma testemunha não aparentada nem com o réu nem com as vítimas para demonstrar que esse, "mais neutro", comprova a versão das vítimas.

- considerou "talvez verídica" a versão de que o réu deu $01^{\circ}$ tiro para o alto, mas afirmou: "Ao que tudo indica, depois disso, o réu ficou confiante e executou a vítima, 
mesmo já estando ela intimidada. (...) Não houve legítima defesa! (...). Não existem duas verdades! Ou foi de um jeito, como conta a família do réu, ou foi de outro, como conta a vítima não fatal e uma testemunha não ligada a nenhuma das duas partes. (...) Os Srs. jurados podem pensar: o réu tinha o direito de se defender, atacando e prevenindo-se de uma agressão futura contra seu sobrinho, já tendo inclusive havido uma agressão anterior contra seu irmão "S". (...) Mas é duro engolir que o réu tenha atirado na cabeça da vítima sem intenção de matála.(...) E a tal faca que estaria na mão da vítima fatal e que não foi citada por nenhuma testemunha em juízo? Mesmo o menor, sobrinho do réu, não mencionou essa faca."

- o promotor, então, voltou a antecipar que a defesa diria que o réu não teve intenção de matar as vítimas, e reiterou mas que a testemunha não aparentada com nenhuma das partes mencionou terem sido vários os tiros disparados dados pelo réu na direção das vítimas. "Até um parente do próprio réu, mencionou terem sido vários os tiros dados por ele!" (...) Por que o réu fugiu? Por que se desfez da arma? Se tivesse dado um só disparo ou mesmo dois, porque não apresentou a arma à polícia, para que um laudo pericial constatasse sua versão?"

- Escrevi, em seguida: Que ingênuo esse argumento...Por que um negro, que acabou de acertar alguém com um tiro, mesmo que tivesse dado "só" dois tiros - um para o alto e outro na direção de um grupo -apresentaria a sua arma à polícia?

- prosseguiu o promotor: "Qualquer um, diante de ameaças a familiares, faria algo. Se a defesa disser isso, eu estarei de acordo. Mas o que o réu fez foi desastroso. (...). E digo mais! A vítima fatal também tinha antecedentes. Roubo e contravenções relacionadas à tóxicos. Nenhum dos dois é santo, mas $M 1$ recebeu pena de morte das mãos do réu e, neste país, a lei não prevê aplicação de pena de morte. (...) Logo, condenar o réu não será tirar da sociedade uma pessoa super bem intencionada."

- Em tom de finalização, pediu aos jurados que condenassem o réu pelo homicídio consumado e pela tentativa. Argumentou que as penas prováveis seriam 6 e 4 anos, respectivamente, totalizando 10 e que, como não são crimes hediondos, poderia haver progressão para o regime semi-aberto, após o cumprimento de $1 / 6$ dos 10 anos, ou seja, após um ano e meio.

- 14h53': encerrou sua sustentação oral.

\section{$\rightarrow$ Sustentação oral da defesa (advogada-mãe).}

- Se não estivesse de toga, passaria por uma típica mãe, dona-de-casa, classe média: meia-idade, ar singelo, cabelos pintados, curtos e meio armados. 
- saudou o juiz, o promotor, os PMs, a "platéia" e os jurados. Posicionou-se, quase o tempo todo, à frente dos jurados, andando pouco. Quando interpelada pelo promotor, apenas virava a cabeça em sua direção, com ar de enfado.

- voz baixa, porém firme.

- elencou, objetivamente os seguintes argumentos:

a) o réu, à época dos fatos, estava com sua capacidade motora reduzida, portanto, nessas condições, não enfrentaria uma turma;

b) o irmão e o sobrinho, apesar de não terem morrido naquela ocasião, foram assas sinados, posteriormente;

c) M1, vítima fatal, foi quem esfaqueou "S", irmão do acusado;

d) o réu foi socorrer o sobrinho, ameaçado de morte;

e) o réu, seu sobrinho e duas mulheres que os acompanhavam enfrentaram uma turma numerosa e perigosa, o que representa uma situação de extrema tensão;

f) todo o processo leva à tese da legítima defesa, porque há menções à faca que portava a vítima $\mathrm{M} 1$;

g) "M2, a vítima da tentativa de homicídio, não admitiu, num $P$ depoimento, ter sido baleado pelo réu. Só depois, começou a acusá-lo. "Como uma vítima de tentativa de homicídio, na $t^{2}$ vez que depõe, não admite que foi vítima?"

- 15h05' $\rightarrow$ o promotor interrompe-a, comentando que houve acareação de M2 com o réu (fls. 74). A advogada e o promotor começaram a falar ao mesmo tempo, de modo que não se podia entendê-los.

- retomando a palavra, disse a advogada que a progressão da pena não é tão simples quanto afirmou o promotor e que não se pode condenar alguém com o argumento de que a pena será reduzida.

- instaurou-se nova discussão entre promotor e advogada, a qual terminou com a advogada afirmando: "Ora, Doutor... Não venha me dar lições sobre execução da pena. Execução de pena é a menina dos meus olhos. É o tema de minha pósgraduação na USP. Na USP!"

- o último argumento da advogada foi que a vítima tinha piores antecedentes consumo e tráfico de drogas - que o réu.

- houve, então, novo bate-boca entre advogada e promotor, o qual, irônica e sarcasticamente, comentou que a "F.A" — folha de antecedentes — do réu era muito pior que a da vítima (condenação por roubos, um deles com seqüestro). 
- a advogada, irritada, retrucou que o réu já fora condenado por cárcere privado e não por seqüestro.

- Registrei: o auge do de bate entre promotor e advogada girou em torno da questão de quem tinha a pior folha de antecedentes: réu ou vítima e de, portanto, se a vítima merecia ou não morrer.

- 15h10' - a advogada encerrou sua fala e passou a palavra a seu filho, o outro defensor do réu.

\section{$\rightarrow$ Sustentação oral da defesa (advogado-filho)}

- barba bem feita, gordinho, baixo, voz mais baixa e menos firme que a da mãe. Posicionou-se, a maior parte do tempo, na frente dos jurados e andando no espaço existente entre esses, o juiz e o réu. Deixou o promotor interrompê-lo mais do que sua mãe.

- fez novas saudações ao juiz, promotor, oficial de justiça, PMs, "platéia" e jurados. A esses disse: "Considero os Srs. os mais importantes componentes do Júri e os admiro por deixarem seus afazeres para, nesta tarde, julgarem um de seus pares".

- afirmou que a vítima M1 levou um tiro na cabeça porque estava "metido no meio de um rolo", o qual só aconteceu porque, antes, envolveu-se no esfaqueamento de "S", irmão do acusado. Afirmou, ainda, que se M1 não tivesse morrido, provavelmente, teria em sua folha de antecedentes uma tentativa de homicídio qualificado contra "S".

- nesse instante, irrompeu o promotor perguntando ao advogado se ele tinha ao menos o boletim de ocorrência do qual constava que M1 esfaqueou "S";

- o advogado, quase balbuciando e logo passando para outro tema, disse não ter o B.O.

- o promotor, de pé, falou com desdém: "É mera presunção concluir que M1 esfaqueou " $S$ ".

- 15h20': o advogado leu o depoimento de uma das testemunhas, tentando com ele provar que "S" fora esfaqueado por M1. O promotor, novamente, interrompeu-o, dizendo: "Se, desde março deste ano, os digníssimos colegas advogados defendem o réu neste processo, já tiveram tempo suficiente para levantar 0 eventual B.O. que prova a agressão de M1 contra S."

- promotor e advogado começam a trocar insultos:

$\Rightarrow$ Promotor: O Sr. está fazendo um carnaval com a ficha de antecedentes da vítima! 
$\Rightarrow$ Defensor: Carnaval, não! Isto é o meu trabalho.

$\Rightarrow$ Promotor: Carnaval, sim! Pois a vítima...

$\Rightarrow$ Defensor: Se o Sr. insistir nesse termo, eu pedirei para que isso conste em ata como ofensa a minha pessoa, pois acima das nossas divergências está a lei, representada pelo Exmo Sr. Juiz. Estão também o Ministério Público e a OAB, instituições que nós dois representamos e que devemos honrar. Há ainda os senhores jurados que não vieram aqui para participar de nenhum carnaval, assim como os estudantes e o próprio réu!

$\Rightarrow$ Promotor: Ora, doutor... Estou só falando que o Sr. está invertendo a importância das coisas ao querer transformar a vítima num bandido.

$\Rightarrow$ Defensor: Eu sei muito bem o que estou fazendo, não estou invertendo nada e o aparte concedido está terminado.

- Retomando a palavra, o advogado afirmou que o acusado, "um aleijado que protegia um menino" deu um tiro para cima e mais um tiro na direção do grupo de "traficantes", não havendo provas de outros tiros.

- Anotei: Imagens perfeitas - um aleijado protegendo um menino $X$ um grupo de traficantes.

- Novo bate-boca:

$\Rightarrow$ Promotor: "Onde consta que o réu, à época dos fatos, estava aleijado?"

$\Rightarrow$ Advogado: "Está nos autos".

$\Rightarrow$ Promotor: "Em que folhas dos autos?"

$\Rightarrow$ Advogado: "No interrogatório do acusado, de hoje."

$\Rightarrow$ Promotor (ironicamente): "Ah! Então estará nos autos, porque só hoje o réu se lembrou de contar isso!..."

- o advogado, desviando do assunto, lembrou que a "suposta vítima da tentativa de homicídio" - M2 - encontrava-se presa.

- Registrei:

$\Rightarrow \mathcal{A}$ fala do advogado-filho seguiu a mesma linha da fala de advogada-mãe. Defenderam o acusado pela de preciação das vítimas.

$\Rightarrow \mathcal{A s}$ trocas de farpas, entre promotor e advogado, também basearam-se, por parte do promotor, na desqualificação técnica do advogado - falta de provas em suas afirmações.

- perguntou o advogado aos jurados: "Por que o réu iria à praça com sua mãe e sua irmã? Porque sua intenção não era a de matar alguém, mas apenas a de proteger seu sobrinho!" E, novamente, falou mal da vítima: "Seu apelido era maluco. Ele usava drogas e estava desempregado. O que esperar de alguém cujo apelido é maluco?"

- como, enquanto isso, o promotor sussurrava, ao microfone, que o acusado estava cumprindo pena, o advogado comentou que, de fato, seu cliente já participara de um roubo, pelo qual foi condenado e cumpria pena, razão por 
que entrara com pedido de revisão criminal, pois não conformara-se com a condenação.

- depois de uma pausa, de folhear o processo e de olhar o relógio, o advogado comentou que a mãe das vítimas M1 e M2, no depoimento que dera em jú́o, alegou que M2 não fora vítima, só M1, "(...) logo, esse depoimento exime o réu da tentativa de homicídio, pois esse delito não ocorre. É uma fantasia, uma elocubração."

- das $15 \mathrm{~h} 43^{\prime}$ às $15 \mathrm{~h} 45^{\prime}$ um jurado pediu para ir à toalete, o advogado interrompeu sua fala e ficou conversando com a advogada-mãe.

- ao retomar sua sustentação, afirmou: "A testemunha, mencionada pelo promotor como neutra, por não ser parente nem do réu nem das vítimas, tem fértil imaginação e deu depoimentos repletos de contradições e incoerências". Leu os depoimentos dela, enfatizando as dubiedades.

- Leu, também, o depoimento da mulher do réu em que ela citava a agressão sofrida por "S".

- A essa altura, tive a nítida impressão de que o advogado estava gastando o tempo que ainda restava-Ihe e, para isso, procurava peças que pudesse ler para reforçar as idéias já expostas.

- Os jurados estavam visivelmente cansados: esfregavam os olhos, o rosto, apoiavam a cabeça numa das mãos, olhavam para o teto enquanto esticavam as pernas e , massageavam ombros e pescoço.

- o advogado prosseguiu lendo depoimentos em que afirmava a intenção da vítima M1 agredir o réu.

- lembrou que as qualificadoras constantes da denúncia não foram reconhecidas pelo Tribunal de Justiça quando da sentença de pronúncia, o que concluiu ser importante ponto a favor da não intenção do réu matar as vítimas.

- nesse momento, criou-se nova polêmica entre promotor e advogado e, como eu também estava muito cansada, perdi o fio do debate.

- 16h10' $\rightarrow$ encerrou-se a fala do advogado

\section{$\rightarrow$ Réplica da acusação}

- o promotor começou lembrando que, na sentença de pronúncia, o juiz afirmara serem conclusivas as provas da tentativa de homicídio contra M2;

- isso bastou para instaurar-se nova discussão com os advogados, a qual foi carregada de termos técnicos. O promotor, numa certa altura, apontou que 0 
advogado-filho confundia apelação com recurso em sentido estrito. A "advogada-mãe" defendeu o "advogado-filho" e a discussão durou alguns minutos. $O$ juiz não estava na sala.

- o promotor, alterado e saindo da discussão técnica, explodiu:

$\Rightarrow$ "Se o esfaqueamento de Sebastião, irmão do réu, por M1, motivou o crime, por que a defesa não trouxe cópia do inquérito policial que registra ser M1 o autor do esfaqueamento? Porque não convém!! O réu, sem provas, foi tirar satisfações da vítima M1 e matou-a. Esse foi o motivo do crime! Quanto ao réu estar semi-aleijado à época dos fatos, por que isso foi dito somente hoje pelo réu? Por que ninguém mencionou isso antes?"

- também lembrou o promotor que, quanto ao acusado ter disparado mais de dois tiros, embora não tenha sido encontrada a arma, diferentes testemunhas mencionam "vários" tiros.

- de forma contundente, reafirmou haver provas de que a vítima M1 não portava uma faca na ocasião do crime.

$\Rightarrow$ Promotor: "Essa hipótese surgiu, posteriormente, para dar aos advogados condições de sustentarem a tese da legítima defesa. Não admito que atirar na direção de alguém seja diferente de atirar em alguém, conforme disse o advogado. Atirar na direção é mirar alguém. E não admito que qualifiquei a vítima de anjinho. Eu disse que vítima e réu não eram flores que se cheiram. Ambos têm folhas de antecedentes ruins. Eu não poria nenhum dos dois para dormir na minha casa. E não existe, no processo, provas de que M1 era um drogado e que estava drogado no dia dos fatos. M1 tinha que pagar por seus delitos perante a justiça, mas não perante o réu que a julgou e a matou. Não existe pena de morte no Brasil! O argumento da defesa, de que a vítima era medonha, é quase nazista, pois sugere que ela merecia morrer."

- por fim, o promotor resumiu seus argumentos, mais uma vez reiterando que não havia se configurado a legítima defesa e que o réu deveria ser condenado por um homicídio consumado e outro tentado.

\section{$\rightarrow$ Tréplica Da Defesa (advogado-filho)}

$\Rightarrow$ "Mesmo que o acusado tivesse dado 10 ou 20 tiros na direção das pessoas, isso não o tornaria mais culpado porque, justamente, ele não queria atingir ninguém, em especial."

- o advogado lembrou que, num dos depoimentos do sobrinho do réu, esse acusara M1 de empunhar uma faca, enquanto esperava-o sair de uma lanchonete.

- novamente, entrou em detalhes técnicos, lembrando que o primeiro advogado do réu, à época em que foi dada a sentença de pronúncia, apresentou recurso 
em sentido estrito, mas sem razões, daí o recurso ter sido improvido: "Se houvesse tais razões, provavelmente, o Tribunal de Justiça teria absolvido o réu!"

- novos bate-bocas técnico-jurídicos, entre promotor e defensor, até que o primeiro dirigiu-se ao juiz com "uma questão de ordem": "O Tribunal de Justiça, mesmo sem a defesa ter apresentado razões no recurso em sentido estrito, poderia ter absolvido o réu, sumariamente?" O juiz respondeu-Ihe que sim.

- com ar de satisfação, o promotor, virou-se para os jurados e, sem palavras, apenas expressando-se com o rosto e o corpo, deu a entender que o réu fora e continuava sendo mal defendido.

- foi a única vez em que o juiz participou das argüições.

- O advogado, finalmente, leu os quesitos para os jurados e sugeriu quais respostas eram as "corretas". Reiterou que o acusado não atirara contra as pessoas e sim na direção de um grupo que ameaçava a ele e a seu sobrinho.

- pediu a absolvição do réu pelo homicídio consumado, em função de ter agido em legítima defesa, e alegou a inexistência do homicídio tentado.

\section{$\rightarrow$ Votação secreta}

- 16h53': o juiz convidou os jurados a se retirarem para a sala secreta.

- Não presenciei a votação e não soube, posteriormente, os resultados de cada quesito (quantos "sim" e quantos "não").

\section{$\rightarrow$ Leitura da sentença}

- 17h20' $\rightarrow$ retornaram os jurados, juiz, promotor e advogados;

- 17h22' $\rightarrow$ retornou o réu, que foi conduzido para a frente do juiz, ficando de costas para a "platéia". Todos foram convidados a se levantar e o juiz leu a sentença que absolveu o réu das duas acusações.

- a reação da mãe e das moças que a acompanhavam foi marcada por sorrisos lacrimosos, abraços e mãos em posição de oração levadas à boca e ao alto. $A$ mãe, saindo do plenário, exclamou: "Foi Deus quem salvou meu filho. De novo, foi Deus! É Deus quem protege meu filho. É por causa de Deus que ele está vivo! Obrigada, Senhor, por iluminar esse juiz! Obrigada, Senhor juiz!"Aproximei-me delas, para ouvir melhor o que diziam, entre si:

$\Rightarrow$ Mãe: Eu sabia que Deus faria Justiça.

$\Rightarrow$ Irmã: Ele já sofreu tanto...

$\Rightarrow$ Mulher: Se tinha de pagar seus pecados, já pagou! 
$\Rightarrow$ Mãe: Ainda bem que Deus iluminou essa gente aqui. Deus seja louvado e abençoe a todos! $!^{10}$

\section{$\rightarrow$ Observações finais}

- não fiquei com cópia desse processo;

- o fato de a dupla de defensores ser formada por mãe e filho pesou a favor do réu, pois deu credibilidade à defesa, especialmente por ser a advogada-mãe uma senhora.

- questão-chave que me pareceu estar em jogo e ser respondida afirmativamente pela sentença: Tinha o réu, de acordo com as narrativas dos arguidores, motivos legítimos para matar a vítima?

- O caso envolveu:

a) parentesco: proteção que um familiar dá a outro - réu em relação ao sobrinho e mulheres em relação ao réu - e vingança — do sobrinho em relação às vítimas prováveis agressoras de seu pai.

b) vizinhança: réu e vítima eram do mesmo "pedaço";

c) drogas;

d) jovens e menores;

e) pobreza;

f) mortes de vários dos envolvidos: da vítima, do sobrinho e de "S".

g) conflitos do espaço privado - provável esfaqueamento de "S", no interior de uma casa - que resolvem-se no espaço público - "Praça Brasil".

\section{- Topografia social do Júri}

Finalizando este capítulo e ainda explorando a idéia da prática etnográfica enquanto uma leitura interpretativa de materiais sociais, vale recordar que, ao descreverem espaços urbanos, como o palácio de Versalhes, o plano piloto de Brasília, lugares de Roma, a Praça Zócalo na Cidade do México e a Praça Vermelha, em Moscou, diferentes antropólogos apontam esses locais como teatros em que o poder mostra-se e afirma-se: "A topografia simbólica de uma cidade é uma topografia social e política (...). Certos lugares exprimem o poder e impõem seu ar sagrado melhor do que qualquer explicação. (...) O espetáculo visual é suficiente, não sendo necessárias palavras."(Balandier 1982: 10-12 ${ }^{11}$ ).

\footnotetext{
10 - interpretações que fiz das reações dessas mulheres, do que se sucedeu após a proclamação da sentenç a e de outros aspectos desse julgamento, encontram-se, especialmente, no capítulo 3.

11 - especificamente sobre Brasília, ver HOLSTON, James - A cidade modernista: uma crítica de Brasília e sua utopia. São Paulo: Companhia das Letras, 1993.
} 
Assim, também, de certa forma, são os fóruns criminais em que estão instalados os plenários do Júri, especialmente o novo fórum em que funciona $01^{\circ}$ Tribunal, situado na Barra Funda. De inspiração nitidamente "Niemeyer", é um prédio de proporções gigantescas, de concreto e vidro, com linhas retas moldando seus limites e linhas curvas formando grandes arcadas através das quais há entradas, saídas e janelas. Circundado por uma grande área asfaltada para estacionamento de veículos, a qual reclina-se a sua volta como uma praia ao redor de uma ilha, tem-se, de sua entrada principal, uma visão de praticamente $360^{\circ}$ das cercanias. Ao longe, num dos horizontes, erguem-se prédios altos dos bairros de Higienópolis e Barra Funda e, do lado oposto, estão as montanhas da Serra da Cantareira. O acesso ao local se dá por um conjunto de largas avenidas, próximas à Marginal do Tietê.

No interior do prédio, inicialmente planejado para ser um hospital, corredores largos são denominados "avenidas" e outros, menos largos, recebem o nome de "ruas". Uns e outros distinguem-se por números e letras. Num grande hall central, erguem-se rampas sobre um jardim em desnível, coberto por diferentes tipos de eras e plantas que recebem luz natural filtrada através de um grande teto envidraçado. Todo o conjunto é climatizado, pois as janelas, de vidro escuro, são fixas e mantêm-se fechadas.

Certa vez, perguntei a uma jurada, que já atuara no prédio do antigo $1^{\circ}$ Tribunal, o que ela achava do novo ${ }^{12}$ :

$\Rightarrow$ Ela: Nossa! Nem se compara! Aqui a gente tem a sensação de entrar no futuro, enquanto lá tudo parecia velho e decadente.

$\Rightarrow \mathrm{Eu}:$ A Sra acha que alguma coisa mudou nos julgamentos em função disso?

$\Rightarrow$ Ela: Ah!... Aí eu não sei, porque as pessoas são as mesmas. Mas acho que aqui todo mundo se sente mais importante, desde o momento que chega. É como se houvesse algum poder no ar, entende?

$\Rightarrow \mathrm{Eu}:$ A Sra poderia explicar melhor?

$\Rightarrow$ Ela: Ah!... Aqui a gente se sente pequeno nesses corredores e parece que o mundo lá fora parou. A gente não ouve barulhos, nem sabe se está chovendo ou fazendo sol. Essa história de terem posto ar condicionado e vidros escuros, em tudo, também faz a gente se sentir meio estranho, meio isolado.

$\Rightarrow \mathrm{Eu}:$ E dentro do plenário? A Sra sentiu alguma diferença?

$\Rightarrow$ Ela: Por ser tudo novo, moderno, limpinho, parece que todo mundo toma mais cuidado. Como em ônibus novo, sabe? Quando está tudo brilhando, ninguém suja.

$\Rightarrow$ Eu: $E$ que tipo de cuidado a Sra percebe que todo mundo está tomando dentro dos plenários?

$\Rightarrow$ Ela: Acho que mesmo no fórum velho, quando as pessoas entravam no plenário, já havia um certo acanhamento: falavam mais baixo, não sentavam de qualquer jeito, não riam. Aqui, continua acontecendo isso, mas porque os plenários são claros, limpos. Parece que tudo está preparado prá cada um agir direito, com respeito, entende?

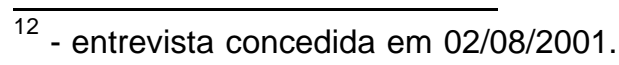


É clara, na fala da entrevistada, uma associação entre as características arquitetônicas do novo fórum e o que elas inspiram em quem transita por ele. A magnitude dos espaços e o fato de serem novos e limpos são percebidos pela jurada como elementos que contribuem para que os ocupantes sintam-se, ao mesmo tempo, respeitados e respeitosos. A forma como os espaços do fórum estão estruturadas ganha significados, o que, por sua vez, só ocorre porque nelas são projetadas lembranças, valores e expectativas.

Excetuando-se esse novo fórum, inaugurado em dezembro de 1999, os outros quatro Tribunais paulistanos do Júri continuam instalados em prédios que têm em comum a falta de imponência e de solenidade. Tanto por fora quanto por dentro, esses edifícios não lembram tradicionais e pomposos tribunais que, geralmente, estão no imaginário de muitos de nós, uma vez que são recorrentes em filmes norte americanos. Trata-se de edifícios que passam desapercebidos na paisagem urbana e, pelo que pude observar, seus corredores e salas administrativas não causam, nos que por ali transitam e trabalham, a sensação de que estão num espaço especial, não profano. Uma sensação de solenidade e mesmo de sacralidade só se impõe no interior dos plenários, durante os julgamentos, e isso se passa devido ao ritual: a suas regras, hierarquias, interditos e, principalmente, em função do poder que está em jogo.

De um modo geral, esses prédios impessoais têm aspecto de despojadas repartições públicas. Em suas entradas, costuma haver um ou mais policiais que, dependendo do "jeito" de quem chega, solicitam a identificação. Eu mesma, só para testar o "olhar clínico" dos recepcionistas, entrei, várias vezes, com "jeito de advogada" ou "de estagiária" - roupas contidas e elegantes, ar compenetrado e preocupado, passo apressado, carregando maleta e processos - e só fui barrada uma única vez, ocasião em que "saquei" a minha carteira da OAB. A reação foi a esperada: "Desculpe, doutora, pode entrar!"

Chegar com "jeito de estudante" — roupas mais despojadas, informais, olhar curioso, pastinha plástica na mão — é ficar naquela posição intermediária de quem pode ou não ser interceptado. No caso de homens, geralmente basta o uso de terno e gravata para seguirem em frente. Mas, qualquer pessoa, mais simplesmente vestida, pode ser barrada ou toma a iniciativa de barrar-se, informando quem é, porque está ali e/ou pedindo orientações.

No interior dos corredores, continua visível, através de uma linguagem essencialmente corporal, a diferença entre quem está lá porque é profissional do Júri, 
funcionário ou réu e familiares desse. Os réus presos e algemados chegam de camburão, por entradas privativas, e são levados diretamente para ambientes isolados - saletas ou mesmo celas - , onde permanecem vigiados por policiais militares, aguardando o início do julgamento, de modo que o mais comum é só vê-los nos plenários.

A maioria dos espaços físicos, especialmente os corredores dos tribunais paulistanos do Júri, lembra "instituições totais", tanto que, não é por mera coincidência que os prédios do antigo e do novo $1^{\circ}$ Tribunal foram concebidos para abrigar, respectivamente, uma fábrica e um hospital. Por si mesmos, esses prédios comunicam que há ali algum tipo de controle, de vigilância e que, seja pela magnitude e modernidade, seja por uma certa decadência, existe um poder que atinge os corpos, neles materializase e através deles se exercerá (Foucault, 1984).

Quanto à localização geográfica dos prédios, cabe ressaltar que encontram-se em bairros relativamente centrais da cidade e não em pontos que representariam as regiões de competência de cada Fórum. Inclusive os nomes pelos quais cada Tribunal do Júri é mais conhecido, correspondem aos nomes dos bairros onde se localizam - Tribunal da Barra Funda (antes da Vila Mariana), da Saúde, de Santo Amaro, da Penha e de Pinheiros -, o que não favorece a percepção de uma São Paulo dilatada por vastas periferias. Esses "apelidos", mais do que um caráter meramente geográfico, revelam locais mais associados a referenciais cotidianos de manipuladores técnicos e jurados de classe média do que de réus e vítimas.

Para a maioria dos réus soltos seus parentes e testemunhas, e mesmo para funcionários menos qualificados dos Fóruns, deslocar-se para esses bairros representa horas e dinheiro gastos em mais de uma condução. Conforme declarou-me uma funcionária do $3^{\circ}$ Tribunal do Júri - Santo Amaro - " "Moro do lado de uma delegacia, mas levo mais de uma hora prá chegar aqui. Mas tem muito mais delegacia do que tribunal, não é mesmo? Policial, bem ou mal, a gente vê a toda hora. Juiz, tem gente que só vê quando vai pro banco dos réus ou tem que testemunhar" ${ }^{13}$. Enfim, morar longe dos Tribunais - condição da maioria dos que não são operadores técnicos —, mais do que um distanciamento geográfico, talvez signifique estar distante da "Justiça", o que, "bem ou mal", conforme declarou a entrevistada, não é a percepção que muitos dos moradores de periferia tem com relação à presença da polícia.

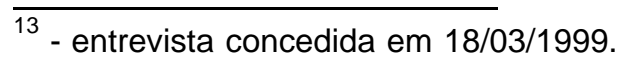


O antigo $1^{\circ}$ Tribunal Júri "de Vila Mariana" ${ }^{14}$, até dezembro de 1999 era o maior e mais importante dos cinco tribunais em termos de quantidade de julgamentos e até da repercussão dos mesmos, pois alguns dos mais polêmicos e mais longos, mesmo que fossem da competência de outro Tribunal, eram ali julgados, por ser tratar do único em que havia apartamentos para abrigar os jurados. Essas características transferiram-se para o novo $1^{\circ}$ Tribunal "da Barra Funda".

O prédio de Vila Mariana, antes de comportar o $1^{\circ}$ Tribunal do Júri era ocupado por uma antiga fábrica, cuja estrutura mal alterou-se de um uso para outro - um grande caixote de cimento, não recuado da calçada e com vários vitrôs altos a circundarem-no.

Os corredores do térreo tinham piso de tacos de madeira, envelhecidos e cobertos na parte central por uma passadeira de borracha, de cor "vinho-sujo-brilhante". As paredes eram brancas, na metade superior, e creme, na inferior. Os altos vitrôs das salas de setores administrativos - dispostas ao longo do corredor térreo e cujas portas permaneciam geralmente abertas - eram ainda protegidos por grades. Próximos às paredes desse corredor, havia alguns bancos, bebedouros e lixeiras presas ao chão por pequenas correntes. No andar superior, onde ficavam os oito plenários (de "A" a "H"), várias placas pendiam do teto com a palavra SILÊNCIO. Esses tetos eram recobertos por canaletas metálicas, pintadas de branco, em meio às quais luzes fosforescentes permaneciam sempre acesas. As paredes divisórias de vários plenários eram de eucatex, imitando madeira de pinho e vedavam mal o som.

Os 8 plenários eram de diferentes tamanhos e, dependendo da repercussão do caso em julgamento, ou seja, do número esperado de curiosos e jornalistas, a sessão realizava-se nos pequenos - para aproximadamente 40 assistentes -, nos intermediários - para mais de 40 e menos de 100 - ou no maior de todos — o plenário "H" - , para um público de aproximadamente 160 pessoas. Em dias de fortes chuvas, goteiras molhavam vários plenários, tumultuando as sessões.

Para os julgamentos mais "concorridos", dias ou mesmo semanas antes, eram distribuídas senhas pelo Juiz Presidente. Nessas ocasiões, o "clima" do Tribunal mudava. A rua costumava ser interditada pelo Departamento de Serviços Viários - DSV - e carros de empresas jornalísticas, rádios e canais de TV instalavam-se nas proximidades. Repórteres e câmeras costumavam ocupar a calçada, diante da entrada principal, e quem quer que desejasse ter acesso ao plenário do referido julgamento devia apresentar sua senha na entrada principal. Funcionários administrativos, em geral apáticos aos

$\overline{14}$ - Rua Afonso Celso, 1065 (04119-061). 
julgamentos, nesses dias costumavam circular apressados pelos corredores que, aí sim, ganhavam um ar não profano.

Em junho de 1996, o Tribunal do Júri de Vila Mariana era o maior da América Latina e contava com aproximadamente 10.000 jurados inscritos. Nessa época, graças à boa vontade do Juiz Presidente, um funcionário foi designado para, seguindo minhas instruções, tabular alguns dados de uma amostra desse universo ${ }^{15}$. A análise do material e esforços para atualizar informações, bem como para conseguí-las nos demais tribunais não desenvolveram-se devido à ênfase qualitativa que, a partir de 1999, deu-se à pesquisa $^{16}$. Contudo, os dados coletados reforçam idéias correntes a respeito do perfil da maioria dos jurados paulistanos: há um pouco mais de homens do que de mulheres compondo as listagens; a maioria possui grau superior, tem mais de 30 anos de idade, trabalha em áreas técnicas, comerciais ou do mercado liberal e é natural da Capital.

O $2^{\circ}$ Tribunal do Júri — "da Saúde" — localiza-se no mesmo quarteirão do antigo Tribunal de Vila Mariana, porém com entrada pela rua paralela ${ }^{17}$. Sua localização, segundo funcionários, há anos, é considerada provisória, não só porque sua circunscrição abrange delegacias de polícia da região norte da cidade, como porque também há

15 - A cada 50 fichas $-\mathrm{n}^{\circ} 01,51,10$, até totalizar 200 fichas - pedi que fossem registrados o sexo, escolaridade, idade, ocupação, naturalidade e estado civil dos jurados. $O$ resultado da tabulação foi:

\begin{tabular}{c} 
Perfil dos Jurados do $1^{0}$ Tribunal do Júri de São Paulo, \\
$\begin{array}{c}\text { segundo listagem fornecida pelo próprio Tribunal }\left(^{*}\right) \text {, em } 27 \text { de junho de } 1996 \\
\text { (amostra aleatória não intencional de } 200 \text { fichas/ universo de 10.000) }\end{array}$ \\
\hline
\end{tabular}

\begin{tabular}{|c|c|c|c|c|c|c|c|c|}
\hline & \multicolumn{2}{|c|}{ Sexo } & \multicolumn{3}{|c|}{ Escolaridade } & \multicolumn{3}{|c|}{ Idade } \\
\hline & Masc. & Femin. & $1^{\circ} \mathrm{Gr}$. & $2^{\circ} \mathrm{Gr}$. & Super. & até 30 & + de $30-40$ & + de 40 \\
\hline $\mathrm{N}^{0 \mathrm{~S}}$ Abs. & 109 & 91 & 10 & 61 & 129 & 32 & 68 & 100 \\
\hline$\%$ & $55 \%$ & $45 \%$ & $5 \%$ & $30 \%$ & $65 \%$ & $16 \%$ & $34 \%$ & $50 \%$ \\
\hline Totais & \multicolumn{2}{|c|}{$200(100 \%)$} & \multicolumn{3}{|c|}{$200(100 \%)$} & \multicolumn{3}{|c|}{$200(100 \%)$} \\
\hline
\end{tabular}

\begin{tabular}{|c|c|c|c|c|c|c|c|c|}
\hline & \multicolumn{2}{|c|}{ Estado Civil } & \multicolumn{3}{|c|}{ Ocupação (**) } & \multicolumn{3}{|c|}{ Naturalidade } \\
\hline & casado & $\begin{array}{l}\text { solteiro, } \\
\text { separado, } \\
\text { viúvo }\end{array}$ & $\begin{array}{l}\text { func. } \\
\text { públ. }\end{array}$ & $\begin{array}{c}\text { Técn. adm., } \\
\text { comerc. e } \\
\text { prof. liberais }\end{array}$ & $\begin{array}{l}\text { bancários } \\
\text { e profess. }\end{array}$ & $\begin{array}{c}\text { SP } \\
\text { capital }\end{array}$ & $\begin{array}{c}\text { SP } \\
\text { inter. }\end{array}$ & $\begin{array}{l}\text { Outro } \\
\text { estado }\end{array}$ \\
\hline $\mathrm{N}^{0 \mathrm{~s}}$ Abs. & 82 & 118 & 26 & 126 & 39 & 137 & 32 & 31 \\
\hline$\%$ & $41 \%$ & $59 \%$ & $13 \%$ & $63 \%$ & $20 \%$ & $69 \%$ & $16 \%$ & $15 \%$ \\
\hline Totais & \multicolumn{2}{|c|}{$200(100 \%)$} & \multicolumn{3}{|c|}{$200(100 \%)$} & \multicolumn{3}{|c|}{$200(100 \%)$} \\
\hline
\end{tabular}

${ }^{*}$ ):Meus agradecimentos ao Juiz Presidente do ${ }^{\top}$ Tribunal do Júri de São Paulo, Dr. José Ruy Borges Pereira e ao Diretor de Serviço José Gustavo Ulhôa Campos.

$\left({ }^{* *}\right)$ :houve $4 \%$ de outras ocupações - estudantes, aposentados, metalúrgicos.

16 - a pretensão inicial era a de não só comparar os mesmos dados entre os cinco tribunais, mas de também compará-los ao perfil dos réus e dos moradores dos bairros abrangidos pelos respectivos Júris. Mais comentários sobre o abandono de certas análises, ao longo da pesquisa, encontram-se no próximo capítulo. 
expectativas de que este e os demais concentrem-se no novo Fórum Criminal da Barra Funda, para onde já se mudou $01^{\circ}$ Tribunal.

Esse Tribunal ocupa o $2^{\circ}$ andar de um prédio que também não se destaca, mesmo em meio a algumas casas baixas e, nesse andar há somente dois largos corredores paralelos, unidos pelo hall dos elevadores e escadas, de um lado e, de outro, pela grande sala do cartório. Há dois plenários ("A" e "B"), situados em cada um dos corredores, que guardam um certo ar de antigos, por terem madeira revestindo a metade inferior de suas paredes.

Como todos os funcionários administrativos ficam na grande sala oposta ao hall dos elevadores, a impressão do lugar é de vazia amplidão. Contudo, só estive nesse Tribunal assistindo a julgamentos pouco "concorridos", de modo que tudo deve mudar quando se trata de um "caso importante".

O edifício do Fórum onde está localizado o $3^{\circ}$ Tribunal — "de Santo Amaro" - é moderno e mais parece um complexo de escritórios ${ }^{18}$. As dependências do Júri ocupam os dois últimos andares e os dois plenários ("I" e "Il") estão no penúltimo. Os espaços dos corredores, salas de juízes, promotores, advogados, cartório e dos próprios plenários e demais dependências do Tribunal são amplos, limpos, bem iluminados, impessoais e dão a impressão de que não foram totalmente ocupados, embora deveriam ter sido.

Como há um vão livre, numa das laterais do prédio, e os plenários estão, cada qual, de um dos lados desse vão, das janelas dos fundos de um plenário se pode ver os fundos do outro. A vista que se tem das demais janelas envidraçadas, que circundam todo o prédio, é a das grandes mansões dos bairros "chácaras" da região de Santo Amaro. Mal se vêem telhados em meio ao verde.

Numa tarde, enquanto eu aguardava o início de uma sessão e observava essa paisagem, uma simpática funcionária, que já me vira por lá, algumas vezes, aproximou-se e comentou" "Olhando ninguém imagina que os crimes que chegam aqui vêm das mais de 700 favelas que estão para além desse verde bonito..." E eu aproveitei para comentar: "Mas os jurados vêm do verde bonito...", ao que ela sorriu e acrescentou: "Os juízes e todos os doutores também! Eu é que não venho nem de lá nem de cá." Mal ela afastou-se, anotei cada palavra, metáforas definidoras de uma acidentada topografia sócio-cultural.

Noutra ocasião, essa mesma funcionária já havia me perguntado, durante o intervalo de uma sessão, se eu era assistente de algum juiz, pois vira-me fazer muitas

\footnotetext{
17 - Rua Joel Jorge de Melo, $424-2^{0}$ andar (04128-080) - Saúde

18 - Avenida Adolfo Pinheiro, 1992 - $8^{\circ}$ andar (04734-003) - Santo Amaro.
} 
anotações e, de vez em quando, consultar um código. Ao saber que eu era "somente advogada e pesquisadora", ela comentou: "É que, às vezes, juízes novos que passam no concurso e ingressam na magistratura vêm assistir às sessões, e a gente, não sabendo, pode dar algum fora". Infelizmente, não houve tempo de eu perguntar-lhe a que tipo de fora ela se referia, mas imagino que fosse algo relativo a formas de tratamento e deferências que, assim como o vestuário e a postura, marcam, como verdadeiras patentes, quem é quem em espaços aparentemente anônimos.

Foi nesse Tribunal que comecei a atentar mais para a maneira como as pessoas percebiam-se e identificavam-se nos plenários, especialmente antes do início das sessões, quando alguns dos potenciais jurados, sentados "na platéia", abordavam-se e entabulavam conversas. Graç as a esses momentos de aproximações e bate-papos, tive e criei oportunidades, nesse e em outros tribunais, para conversar com alguns jurados que, invariavelmente, uma vez esclarecido que eu não era jurada, mas fazia uma pesquisa sobre o Júri, enquadravam-me na categoria "estudante" e tratavam-me com um certo ar professoral.

Para alguns juízes, promotores e advogados que, reiteradas vezes, viram-me, muito atenta, anotando tudo num "caderninho", mais do que estudante, declararam-me, posteriormente, ter pensado que eu preparava-me para prestar algum concurso ou para advogar no Júri. Ao saberem que eu era advogada e desenvolvia uma tese sobre o Júri, consideravam-me, normalmente, uma "quase igual", o que me fazia refletir sobre o quanto classificar é, de fato, condição sine qua non para estabelecer relações, pois permite a todos localizarem-se, seja para criar proximidades ou distanciamentos.

Aproveitei, várias vezes, esse exercício classificatório, tanto com jurados quanto com manipuladores técnicos, para, ora apresentar-me como "advogada e pesquisadora", ora como "advogada e antropóloga", ora apenas como "antropóloga e pesquisadora". Os efeitos, como era de se esperar, não eram os mesmos. A nomenclatura "advogada e pesquisadora" causava melhor impacto do que "advogada e antropóloga" e muito melhor ainda do que "antropóloga e pesquisadora".

Ser antropóloga, sem dúvida, é algo desconhecido de boa parte dos operadores e demais participantes do Júri — para não dizer dos participantes do mundo - , de forma que é uma "classificação que não classifica" e, por isso, causa estranhamento e distância. Existe, portanto, uma hierarquia subjacente a essas reações: ser advogada é mais

$19-05 / 03 / 1999$. 
importante do que ser pesquisadora e antropóloga. Ser advogada é ser "do meio", o que cria uma cumplicidade imediata, enquanto ser pesquisadora é intrometer-se nesse "meio".

Nesse Tribunal, também por várias vezes, ao sair do elevador e encaminhar-me para um dos plenários, funcionários perguntaram-me se eu era jurada, ocasiões em que não pude deixar de pensar em como seria ter adotado o caminho metodológico de tornarme uma. Mas, mal iniciadas as sessões, reconfortava-me a posição de "antropólogapesquisadora-advogada" - minha auto-classificação, nessa ordem.

O local em que está situado o 4 Tribunal do Júri "da Penha", apesar de ser corredor de ônibus, é uma rua estreita, de comércio barato, com muitos pedestres e próxima a uma pracinha. O prédio do Fórum — de concreto e vidro - é mais alto que as construções ao redor, recuado da rua, mas nem por isso, destaca-se na paisagem.

Desde que conheci esse Fórum, em 1990, os ascensoristas faziam, entre uma "viagem e outra", uma espécie de noticiário-expresso do que se passava em cada andar, comentando depoimentos ou audiências de réus "famosos" e/ou "perigosos", resultados de sentenças, fofocas sobre funcionários e manipuladores técnicos. Essa prática perdura.

○ $6^{\circ}$ andar, onde há dez anos, localizava-se o único plenário, hoje divide sua "importância" com o 70, onde está o $2^{\circ}$ plenário. Apesar da criação desse, é visível a sobrecarga desse Tribunal. Todos os seus espaços parecem pequenos e tumultuados. Há grande expectativa, por parte de alguns funcionários, de que ocorra, em breve, a mudança das instalações para a Barra Funda, pois, segundo eles, "Lá sim, o trabalho sairá melhor", uma vez que as condições físicas influenciam o "estado de espírito" de quem trabalha, "podendo ajudar a cansar ou a estimular".

Esse $4^{\circ}$ Tribunal também tem uma aparência de repartição pública, com predominância de tons cinzanos pisos e paredes. A vista que se tem de uma das laterais do prédio é de boa parte do bairro da Penha que, há pouco mais de meio século era um dos pontos mais distantes do centro da cidade, embora, hoje, esteja a menos de meio caminho das periferias mais longínquas, de onde provém a maioria dos casos de homicídio que vão à Júri.

Finalmente, o 5 Tribunal do Júri, de "Pinheiros", que ocupa o último andar do Fórum Regional da região de mesmo nome, fica numa área arborizada e tranqüila. $A$ construção é alta e em estilo moderno - cimento e vidro. Do cartório do Júri avista-se Pinheiros e Vila Madalena, lembrando a paisagem que se vê do Júri de Santo Amaro. Os funcionários - em torno de 15 - trabalham numa grande sala envidraçada, sem divisórias. 
A primeira vez que visitei o local — junho de 1997 —, apresentei-me como "pesquisadora da USP" e isso valeu-me um bom tempo de espera, até ser atendida pelo "chefe do cartório". Atrás de sua mesa, havia dois cartazes. Num deles, uma águia, desenhada dentro de um círculo e rodeada pelas inscrições "United States Navy - Military Sealift Command" ; no outro cartaz, em letras estilo gótico, estava transcrito o "Pai Nosso".

Ainda antes de ser atendida, um advogado aproximou-se do local e perguntou-me se eu era a acusada que iria depôr. Ao responder que não, mostrei-lhe minha identificação de advogada, para testar sua reação. Ele desculpou-se, constrangido, e, nesse momento, fui prontamente atendida pelo escrivão que, também meio constrangido, deu-se conta de que eu era "doutora" começou a tratar-me como tal.

Apesar da longa espera, com facilidade obtive várias informações e, naquela mesma tarde, com a condição de que eu mantivesse os nomes dos jurados em sigilo, entregaram-me todas as fichas com suas referências. Somente nesse Tribunal foi possível ter acesso a elas ${ }^{20}$.

Dos cinco Tribunais, esse é o único que possui somente um plenário e cuja maioria das sessões de julgamento começa pela manhã (10h). Nos demais, o início, durante a maior parte de minha pesquisa, costumava ocorrer em torno das 13h30'. Um funcionário explicou-me: "Os jurados, quando têm que vir, perdem mesmo o dia todo de trabalho. Então é melhor que cheguem antes do almoço, antes de sentirem fome e sono. Além disso, normalmente podem sair antes do entardecer e nós também. É bom prá todo mundo. Isso aqui cansa, sabe?"

$$
\text { (I.) })
$$

Uma das principais afirmações já desenvolvidas é a de que, apesar de nas sessões de Júri, aparentemente, prevalecer um jargão técnico-racional, o conjunto de expressões nelas utilizado baseia-se num "vocabulário de sentimento" (Geertz, 1978: 317). Vimos que esse vocabulário pode ser especialmente observado no transcorrer das

\footnotetext{
20 - no total eram, aproximadamente, 1.250 e, a cada visita subsequente, observei-as, aleatoriamente, até analisar $1 / 3$ do total (411), quando suspendi a observação e tabulei os dados: $49 \%$ de homens e $51 \%$ de mulheres; quase todos ocupando funções de nível técnico, superior ou ligadas ao comércio e administração (96\%). As fichas, datilografadas e com correções manuais apenas continham CEP, RG, nome, profissão, endereço residencial e telefone, endereço comercial e telefone. Por último, constava a filiação. Em conversa com o funcionário responsável pela convocação dos jurados, ele cedeu-me um exemplar da "Carta de Convocação" (V. Anexo 5), a qual todos os sorteados recebem pelo correio.
} 
sustentações orais de acusadores e defensores, à medida que cresce, em todos os presentes, a excitação diante da inevitável sentença que absolverá ou condenará o réu.

Por mais menções que os arguidores façam a provas técnico-científicas e por mais que utilizem um jargão jurídico, o cerne de suas argumentações baseia-se em sentimentos que, esses sim, serão julgados como motivações legítimas ou ilegítimas para condenar ou absolver réus. Por isso, não raras vezes, observamos o caráter secundário de debates sobre se o réu matou ou não a vítima, passando para primeiro plano a avaliação de quais emoções estavam envolvidas na morte - amor, ciúme, vingança, indignação, frustração, medo, rancor, proteção etc - e o quão elas legitimam ou não o ato de matar.

"Ler" as sessões para buscar o tratamento que foi dado, em cena, aos sentimentos evocados, a fim de compreender sua elaboração no contexto dos plenários, é, pois, tomar tais sentimentos como componentes de vários subtextos, cujos significados não são necessariamente harmônicos nem necessariamente opostos. O que importa é que o conjunto desses subtextos - sessão de Júri - representa tanto a exposição de seus autores a uma situação comum de aprendizado sentimental quanto a possibilidade de cada um sistematizar experiências e torná-las inteligíveis para si e para os outros. As expressões de cada caso ocorrem dentro de um idioma geral, o que possibilita a antropólogo classificar sensações e entender coisas a partir de uma estrutura cultural. A compreensão dessa estrutura permite a descoberta da dimensão social de pensamentos e de casos aparentemente particulares, conduzindo à percepção da significação de elementos recorrentes (Darnton, 1986: XVII).

Apesar disso, vale pontuar que os Júris paulistanos não são a única chave para a compreensão de como o Poder Judiciário permite a elaboração de significados de mortes violentas na cidade de São Paulo, do mesmo modo que a briga de galos não o é em relação à vida balinesa e a tourada em relação ao modo de ser espanhol. O que essas afirmativas culturais dizem - sobre paulistanos, balineses e espanhóis - pode ser qualificado ou até desafiado pelo que outras afirmativas, igualmente eloqüentes, também dizem (Geertz, 1978: 320). Porém, o Júri, destaca-se entre outros espaços judiciais, dos quais leigos não participam enquanto julgadores, enquanto uma obra imaginativa que conta com mais co-autores. A presença de leigos como julgadores exige dos operadores técnicos argüições mais ricas em uma espécie de matriz que combina jargão técnico jurídico, imagens de uma "sociologia selvagem" e um vocabulário de sentimento. Por isso, o Júri é um espaço social privilegiado de produção de significações coletivas. Ele possibilita 
que pessoas "comuns" entendam, organizem e demonstrem as estratégias através das quais lidam com a vida. Como essas pessoas não são filósofas - não pensam a respeito das coisas, mas pensam com as coisas, com materiais que a cultura coloca a sua disposição (Darnton, 1986: XIV) —, a cerimônia do Júri e as histórias narradas nos plenários - traições amorosas, tensões entre parentes e vizinhos, pobreza, favelas, subempregos, tráficos de drogas e de armas, pertencer à "classe média" e ser chamado a julgar "em nome da sociedade" - são recursos que nossa cultura disponibiliza para que os presentes entendam o mundo e entendam-se nesse mundo.

Etnografar sessões de Júri, tomando-as como um dos muitos textos que registram a nossa cultura é, portanto, um recorte possível, dentre vários outros, para se falar dessa cultura. Plagiando Geertz, é posicionar-se "por sobre os ombros" de réus, jurados, juízes, acusadores, defensores e testemunhas para tentar perceber o que eles estão percebendo (Geertz, 1978: 321).

Assim posicionada, deparei-me com o que considero uma luta - chancelada pelo Poder Judiciário - pelo monopólio do estabelecimento de formas legítimas e ilegítimas de defender, em certos contextos, determinados valores "até a morte". Contudo, esta tese, ao invés de mergulhar em detalhes desses contextos e valores, detevese na percepção da dinâmica dessa luta, o que implica dizer que ainda há muito o que ler e interpretar em relação ao Júri, às histórias que nele se contam e, consequentemente, aos pormenores da obra imaginativa que é construída nos plenários, a cada julgamento.

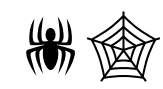




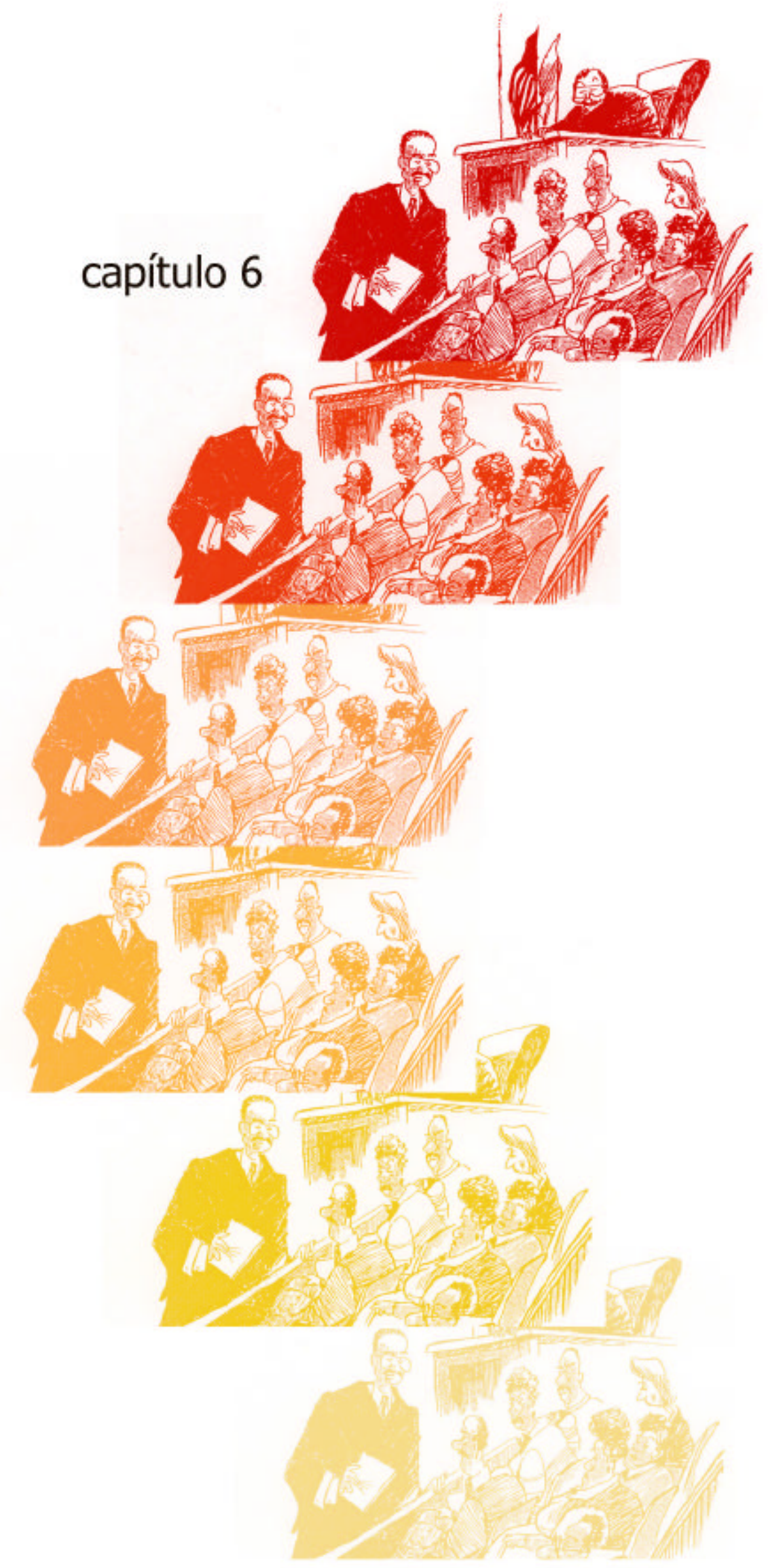




\section{TESE: RITUAL LÚDICO E TEATRALIZADO}

\section{- Introdução}

"O que é uma tese?" pergunta Marcel Griaule a seu orientando Jean Rouch, às vésperas de esse entregar a sua, na Sorbonne, em 1953. Griaule responde: “Uma tese, em etnologia, é um rito de passagem," Tal afirmação tornou-se lugar comum em programas de pós-graduação em Antropologia Social, seja entre orientadores e examinadores, seja entre mestrandos, doutorandos, seus amigos e parentes. Especialmente doutorandos, como costumam relacionar o "fazer a tese" com acontecimentos transcorridos ao longo do doutorado, transformam o compromisso acadêmico em uma verdadeira saga. Não fugi à regra.

Mas não basta reiterar o lugar comum, tampouco desprezá-lo. Quem escreve uma tese intenta mudar de status acadêmico; os examinadores reforçam suas posições; os que acompanham o processo visualizam o sistema de valores em jogo e, finalmente, as horas durante as quais transcorre a defesa constituem uma cerimônia que expressa, transmite e perpetua elementos desse sistema de valores, os quais são, portanto, preservados de questionamentos insolúveis, uma vez que, como em julgamentos judiciais, ao final, chega-se a uma "sentença" de aprovação ou reprovação do que e de quem é avaliado. A "solidariedade do grupo" intensifica-se.

$\mathrm{Na}$ área de humanas, como sujeito e objeto estão invariavelmente implicados, pode-se ainda afirmar que as teses materializam o duplo desafio de o pesquisador amadurecer intelectual e emocionalmente. Tanto isso procede que muitos projetos sofrem alterações decorrentes não só de leituras, participação em cursos e coleta de dados, mas de mudanças de ordem pessoal vividas pelos pesquisadores. Enfim, após anos realizando um doutorado, é corriqueiro confundir-se o conviver com a tese com o viver em função dela, de modo que conclúfla implica reavaliar um estilo de vida.

Não bastasse isso, se fôssemos nos aprofundar em aspectos psico-metodológicos do "estado de fazer tese", teríamos de tratar das dificuldades relativas ao momento crucial de separar o produtor do produto ou o criador da criatura. Afinal, para qualquer pesquisador que faz de sua tese algo mais do que um meio para atingir maior titulação acadêmica, o momento de entregá-la é também o momento de perdê-la e, portanto, de viver um luto. $E$, por mais que a psicanálise, a arte e a natureza demonstrem que separar 
o criador da criatura é condição para que ambos vivam, há um paradoxal sentimento de triunfo e de perda quando da finalização de uma longa e absorvente criação.

Enfim, por tudo isso e por considerar que esta tese, tal como o objeto sobre o qual ela se debruça, possuem um caráter lúdico, ritual e semântico, este capítulo foi escrito. Ele baseia-se na metáfora do cientista enquanto solucionador de puzzles (Kuhn, 1974: 55) ou no do trabalho intelectual e acadêmico enquanto uma espécie de jogo solitário de destreza e aplicação. O pressuposto é o de que elementos de tensão e solução (Huizinga, 1980: 14) dominam a elaboração do trabalho intelectual e de que vale a pena, além de apresentar o resultado final, refletir sobre como chegou-se a ele.

\section{- “Antecedentes acadêmicos"}

Max Weber, ao discutir a ciência como vocação e os papéis que cumprem a paixão, a vocação, a inspiração, a intuição, o esforço árduo e o acaso no êxito do trabalho científico, conclui que, embora não haja vocação sem paixão, não basta a segunda, pois ela é mero requisito para a inspiração - idéia precisa que ocorre ao espírito e orienta a formulação de hipóteses. Cientistas, segundo Weber, podem inspirar-se em intuições de diletantes — os quais não as exploram por insegurança no método de trabalho —, mas, normalmente, só o fazem após esforços árduos. Esses, por sua vez, não substituem a inspiração nem forçam a intuição. Enfim, é da conjugação de todos esses fatores ainda somados a acasos que resultam os trabalhos científicos (Weber, 1983: 25, 26). Com esta tese não foi diferente.

Meu interesse pelo tema "Tribunais do Júri" era paixão antiga e, talvez, ligada a um fascínio por jogos, a uma adolescência marcada pela experiência de fazer teatro amador e de muitas leituras de tramas policiais e "de tribunal". Mas esses gostos e experiências difusos só ganharam força e sentido intelectual em decorrência de uma oportunidade acadêmica específica. Entre agosto de 1988 e março de 1989, já graduada em ciências sociais e em direito e fazendo mestrado em antropologia, participei de uma pesquisa em que foram analisados 297 processos penais, todos julgados pelo $4^{\circ}$ Tribunal do Júri da capital de São Paulo (Penha), no período de janeiro de 1984 a junho de $1988^{2}$. Durante seis meses, a equipe de pesquisadoras freqüentou as dependências desse

\footnotetext{
1 - Esse relato está no vídeo Jean Rouch - subvertendo fronteiras, de Ana Lúcia Ferraz, Edgar Teodoro da Cunha, Paula Morgado e Renato Sztutman, 2000, 41 min.

2 - O trabalho intitulou-se "Justiça Criminal e Violência Urbana", foi realizado para o CEDEC Centro de Estudos de Cultura Contemporânea, teve apoio financeiro da Fundação Ford,
} 
Tribunal, leu processos e deles extraiu dados referentes a perfis de réus e vítimas, testemunhas, jurados, bem como informações sobre a "dinâmica dos acontecimentos", ou seja, a forma como eles eram processualmente registrados, desde sua detecção policial até as sentenças proferidas pelo Júri.

"A pesquisa privilegiou a comparação entre o perfil social dos condenados e o dos absolvidos, com vistas a verificar os móveis extralegais que intervêm nas decisões judiciárias, o contraste entre a formalidade dos códigos e da organização burocrática e as práticas orientadas pela cultura institucional, o entrecruzamento entre os pequenos acontecimentos que regem a vida cotidiana e os fatos que regem a concentração de poderes no sistema de justiça criminal, bem como a intersecção entre o funcionamento dos aparelhos de contenção da criminalidade, a construção de trajetórias biográficas e as operações de controle social." (Adorno, 1994: 134135).

Alguns dos principais resultados quantitativos dessa pesquisa - predomínio de sentenças condenatórias com penas moderadas; de testemunhas de acusação; de jurados de classe média; de condenações de réus já detidos, provenientes do próprio estado de São Paulo, antes ocupados em atividades mal definidas e, em juízo, representados por advogados dativos - suscitaram meu interesse e minha vontade de aprofundar e ampliar a investigação, estendendo-a a outros Tribunais do Júri da Capital.

Do mesmo modo, certos procedimentos metodológicos adotados - negociações e convívio cotidianos com funcionários do cartório, leitura sistemática de várias peças processuais e entrevistas informais com "manipuladores técnicos" ${ }^{3}-$ instigaram-me a imaginar como seria realizar uma "etnografia" daquele e de outros Tribunais do Júri. Fiz uma primeira tentativa ao elaborar um paper para o $13^{\circ}$ Encontro Anual da ANPOCS, em 1989 ${ }^{4}$. Nesse texto, sistematizei algumas anotações de meu diário de campo, especialmente as relativas aos significados dos espaços físicos do 4 Tribunal do Júri para as pessoas que por ali circulavam. Na ocasião, como eu passava horas lendo processos, sentada em alguma sala ou corredor, eram os espaços exteriores ao plenário do Júri os que eu mais e melhor observava: a rampa de acesso ao edifício; o pequeno balcão que fazia as vezes de portaria; os elevadores; a garagem para uso exclusivo de juízes, promotores e carros oficiais; os arquivos mortos; o cartório do Júri; as salas do juiz

coordenação do Prof. Dr. Sérgio Adorno e contou com uma equipe técnica de 3 pesquisadoras: Anamaria Cristina Schindler, Maria Ângela Pinheiro Machado e eu.

${ }^{3}$ - Esse termo foi empregado na pesquisa para designar investigadores, delegados de polícia, peritos criminais, promotores públicos, advogados e juízes, de acordo com o uso que dele já fizera Mariza Corrêa (1983). 
presidente, dos promotores, do cafezinho e da votação secreta. Registrei, portanto, o que esses lugares, aparentemente impessoais, significavam para diversas pessoas, bem como posições e relações que neles elas marcavam, definiam e redefiniam, cotidianamente.

Depois da apresentação desse paper, quando já havia terminado a pesquisa para o CEDEC, acalentei a vontade de aprimorar reflexões paralelas e, especialmente, de prosseguir investigando algo que, até então, eu mal observara: o que se passava nos plenários, do momento em que os jurados convocados chegavam para o sorteio dos sete que comporiam o Conselho, até o desfecho do julgamentos. Esse projeto ficou engavetado, de 1989 até 1995, enquanto eu concluía o mestrado, iniciava minha carreira docente e realizava outras pesquisas acadêmicas e de mercado - período em que aprendi a gostar de metodologia de pesquisa tanto quanto dos temas pesquisados.

Quando do ingresso no doutorado, portanto, eu contava com um interesse pelo Júri decorrente de uma somatória de experiências pessoais e profissionais. Desse conjunto e de alguns acasos nasceu o projeto que, apesar de aceito pelo Programa de Pós-Graduação, modificou-se no decorrer do trabalho.

\section{- Um processo de lapidação}

Um ano antes de meu ingresso no doutorado, o Prof. Sérgio Adorno publicou um artigo no qual retomava a pesquisa que realizáramos no CEDEC, então concluída há cinco anos. Nesse texto, ele a inseria numa reflexão mais ampla, relativa aos dilemas e desafios que se colocam à justiça criminal em uma ordem democrática, abordando especificamente o hiato entre enunciados legais igualitários e situações concretas de discriminação e exclusão.

Uma pergunta-chave estrutura esse artigo: "como é possível estabelecer a identidade entre justiça social e igualdade jurídica em sociedades modernas nas quais esses princípios não se encontram assegurados?"(Adorno, 1994: 134).

E a resposta dada é: "Longe do que sonharam, no final do século XVIII e ao longo do século XIX, os reformadores europeus da justiça penal, a universalidade do tratamento legal, dispensada a quem quer que seja, permaneceu apologia do discurso jurídico-político liberal. Não há quaisquer evidências de que o princípio tenha se consolidado sequer nas tradicionais democracias européias e norte americana. (...). O funcionamento normativo do aparelho penal tem, por efeito, a objetivação das diferenças e das desigualdades, a manutenção das assimetrias, a

$\overline{4 \text { - O paper intitulou-se "Labirintos de um julgamento: etnografia de um tribunal do júri" e foi }}$ 
preservação das distâncias e das hierarquias. Assim, não há porque falar na existência de contradição ou conflito entre justiça social e desigualdade jurídica: a desigualdade jurídica é o efeito de práticas judiciárias destinadas a separar, dividir, revelar diferenças, ordenar partilhas" (idem: 149).

Finalizando a argumentação, Adorno retoma a questão do Júri e afirma que, assim como certas demandas em torno da racionalização da justiça pouco contribuem para assegurar tratamentos jurídicos igualitários - demandas por códigos aperfeiçoados e modernizados, por quadros administrativos bem preparados e por procedimentos formais céleres - também a extinção do Júri pouco contribuiria para diminuir desigualdades jurídicas, pois o problema é a incapacidade de essa justiça fundar o consenso em meio a diferenças e desigualdades.

Essas colocações inspiraram-me e reforçaram minha convicção de que seria relevante, tanto teórica quanto empiricamente, retomar o estudo do Júri para repensálo enquanto perpetuador de desigualdades e diferenças em meio a tentativas legais e teóricas de fundar consensos.

Assim, quando da elaboração do projeto de tese, tomei como ponto de partida teórico a problemática da permanência de práticas autoritárias em processos de consolidação de regimes democráticos e nela tentei inserir reflexões sobre a permanência ou extinção dos Tribunais do Júri no Brasil. Através de leituras, principalmente de artigos e livros jurídicos, levantei quais os principais argumentos contrários e favoráveis ao Júri, quais os comentários e expectativas mais corriqueiros de manipuladores técnicos a respeito de seu funcionamento e do porquê serem de sua competência somente os crimes dolosos contra a vida. Minha estratégia apontava para a investigação de como o Júri era avaliado, externamente, por aqueles que dele participavam e/ou propunham-se a entendê-lo. O foco eram, portanto, os discursos sobre o Júri.

Após as primeiras revisões do projeto pela orientadora, no decorrer de 1996, ficoume claro que tal foco fugia de uma problemática antropológica, pois implicava, a priori, classificar e apontar práticas autoritárias e desigualdades sócio-jurídicas como impedimentos para a consolidação de regimes democráticos. Em outras palavras, tratavase de um pressuposto que praticamente impossibilitava a compreensão das lógicas reguladoras internas dessas práticas autoritárias, bem como as prováveis concepções e vivências idiossincráticas de regimes ditos democráticos. Tal enquadramento ideológico

apresentado no GT Direito e Sociedade em 25/10, $3^{\text {a }}$ sessão. 
da problemática obstava, de antemão, uma percepção antropológica de sutilezas envolvidas no Júri, a partir de seu próprio funcionamento, composição, rotina, "casos".

Depois de mais releituras do projeto, simultaneamente ao cumprimento dos créditos exigidos, quase todos seus itens originais foram revistos e substancialmente alterados. O primeiro desafio foi desfocar a problemática do eixo "autoritarismo democratização" para uma nova abordagem centrada no objeto empírico Júri.

Embora com a pesquisa ainda mal delineada, eu ansiava por "autores que me ajudassem a pensar" e solicitava à orientadora uma bibliografia que me indicasse caminhos. Sua sugestão - de acordo com o que também aponta Renato Janine Ribeiro a respeito do mau uso da bibliografia em Ciências Sociais - foi a de que eu não me prendesse, a priori, a um referencial teórico, mas explorasse vários. Desse modo, diminuiria o risco de condicionar os primeiros passos da investigação a trajetórias já legitimadas, reiteradas, paradigmáticas, embotando, talvez, a possibilidade de reflexões inovadoras, fundamentadas em material inédito. "Um pesquisador deve expor-se a seu objeto mais do que o faz. (...). Na leitura quer dos clássicos da área, quer dos referenciais importantes, tem que se recuperar o senso da aventura. (...). Perde-se de vista, na profissão acadêmica, quer entre os iniciantes, quer mesmo entre os pesquisadores já mais titulados, o senso do que se está fazendo. Insistese demais na forma, nas referências. Dá-se demais importância às autorictates. Toda uma nova escolástica assim se espraia pela profissão universitária. "(Ribeiro, 1999: 191, 194 e 195).

Portanto, minhas primeiras observações empíricas sobre os julgamentos progrediram sob esse incentivo de arriscar opiniões próprias e fundamentadas, sem desprezar referenciais importantes, mas não os tornando camisas-de-força. Visitar os tribunais, percorrer seus corredores, olhar suas salas, perceber seus funcionários e seu público, entrar nos plenários, assistir aos julgamentos e, quando possível, trocar idéias com os presentes, mesmo sem saber, ao certo, o que lhes perguntar foram, de início, experiências aparentemente caóticas, mas, por isso mesmo, decisivas.

Nas primeiras visitas, espaços e pessoas que os ocupavam diziam-me mais do que eu conseguia elaborar, tanto que, durante os primeiros meses, basicamente, fui tomada como estagiária de direito que, com uma "curiosidade ingênua", percorria corredores, entrava em plenários, assistia a julgamentos e anotava tudo.

Foi também nesse ritmo - um pouco ao sabor do acaso e da curiosidade —, que avançaram leituras de livros jurídicos, de trabalhos antropológicos e mesmo de debates sobre o tema do Júri promovidos pela imprensa, por universidades e associações de 
profissionais da área. Essa abertura, aparentemente desordenada dos sentidos, foi encadeando idéias e formando um conjunto de impressões, incompreensões, dúvidas e insighs que, mais do que qualquer lista bibliográfica, ajudou-me a criar um recorte do objeto e, aí sim, a definir melhor um referencial teórico.

Simultaneamente, e seguindo novas sugestões da orientadora, revi o modo como eu inicialmente delineara mal os universos "justiça penal" e "Tribunal do Júri", pois, eu não fazia mediações entre "tensões presentes em processos de consolidação de regimes democráticos" e o objeto empírico Júri. Era como se essas tensões pudessem, simples e mecanicamente, ser observadas no Júri. Partindo, assim, do pressuposto vago e polêmico de que o Brasil enfrenta um processo tenso de consolidação democrática, eu apontava o debate em torno da permanência ou extinção do Júri como uma espécie de termômetro dessa tensão. Estava implícita a hipótese de que os defensores da permanência do Júri representavam o lado democrático dessa tensão e seus detratores o lado conservador. Em decorrência disso, nos primeiros relatórios, parti de pressupostos ideológicos quase maniqueístas que bloqueavam o desenvolvimento de uma compreensão do Júri enquanto instituição polissêmica, existente num contexto em que convivem e interagem múltiplas significações.

Revendo, então, tanto as primeiras anotações feitas em campo quanto possíveis mediações entre "justiça penal" e "Tribunal do Júri", reelaborei as questões do projeto original, tentando melhor especificá-las:

$\Rightarrow$ Como, no Tribunal do Júri, os participantes gerenciam significados ao produzir o ato de julgar?

$\Rightarrow$ Qual a gramática do ritual dos julgamentos realizados pelo Tribunal do Júri - suas regras formais, previstas na legislação vigente - e como ela é apreendida e utilizada por "manipuladores técnicos" e jurados?

Essas novas questões recortaram, no vasto universo da "justiça penal", composto por várias formas de organização e de julgamentos — inclusive alguns ilegais, como linchamentos, grupos de extermínio etc —, o micro-universo dos "julgamentos pelo Tribunal do Júri", permitindo-me pesquisá-lo, não mais sob o prisma do "autoritarismo $X$ democracia", mas em busca de lógicas internas responsáveis pelo funcionamento das sessões de julgamento.

Sob essa nova perspectiva, que já apontava tais julgamentos como rituais orientados por uma dinâmica própria, a ser compreendida "em ato", não mais cabia enfatizar a "incapacidade da justiça penal de fundar o consenso em meio a desigualdades e 
diferenças" (Adorno, 1995: 149), pois, para aquilatar-se tal incapacidade, seria necessário adotar um "critério externo de capacidade", procedimento esse que deslocaria a análise do Júri, em si, para discussões externas a ele.

Estava, portanto, definindo-se uma das linhas mestras do que veio a ser a tese: investigar narrativas do Júri sobre a sociedade - geradas durante as sessões - e não mais narrativas da sociedade sobre o Júri - geradas pela imprensa, por profissionais do direito, em debates públicos etc.

Descartei, assim, uma das principais perguntas-problema originais - "Serão os atores do júri produtores de decisões que podem ser consideradas democráticas?". Essa questão pressupunha democracia como um conceito positivo e adotava-o como critério para avaliar valores e atitudes dos atores do Júri. Com ela, eu perdia de vista o problema propriamente antropológico de investigar a produção do ato de julgar no campo específico do Tribunal do Júri, ou seja, a partir da própria lógica produzida nesse campo.

Outras questões, aos poucos, passaram a orientar o trabalho:

$\Rightarrow$ Quais valores, afetividades e influências estão presentes no caleidoscópico campo dos julgamentos pelo Tribunal do Júri e transparecem no decorrer das sessões?

$\Rightarrow$ Como, nesse campo, em que múltiplos vetores interagem, é gerenciado o ato de julgar e como é conduzido tal gerenciamento ${ }^{5}$

$\Rightarrow$ Como expressam-se e combinam-se (mais do que se opõem), na situação do julgamento, textos legais, regras técnicas e bagagens existenciais, também caleidoscópicas, de manipuladores técnicos do Júri e de jurados?

$\Rightarrow$ Segundo sua "gramática legal" e segundo sua "prática coloquial", o ritual dos julgamentos pelo Júri objetiva diferenças e desigualdades? Mantém assimetrias? Preserva hierarquias? Quais? Como essas "gramática" e "práticas" organizam tais diferenciações?

Passei a reorientar leituras e observações de campo a partir dessas questões. Esse reesquadrinhamento de meu olhar sobre o Júri implicou considerar o conjunto de valores e afetividades em jogo, nos plenários, como algo que ganhava sentidos específicos naqueles espaços simbólicos, os quais deveriam ser observados "de dentro" — através de etnografias das sessões - e não "de fora" - através de debates técnico-

5 - O conceito de "campo", aqui utilizado, aproxima-se do conceito elaborado por Bourdieu ao definir campo científico como "(...) o lugar, o espaço de jogo de uma luta concorrencial. O que está em jogo especificamente nessa luta é o monopólio da autoridade científica definida, de maneira inseparável, como capacidade técnica e poder social, (...) capacidade de falar e agir legitimamente (isto é, de maneira autorizada e com autoridade), (...)" (Bourdieu, 1983: 122-123). 
legais, notícias veiculadas pela mídia, filmografia disponível ao grande público em videolocadoras etc.

Porém, no relatório apresentado para o exame de qualificação, mantive a dupla perspectiva de etnografar as sessões - para perceber o que os participantes do Júri elaboravam a respeito da sociedade - e de considerar o que discursos externos ao Júri elaboravam a seu respeito. Somente após as mais de três horas de debate com os examinadores, convenci-me de que valia a pena abandonar a segunda perspectiva e explorar, ao máximo, a primeira. ${ }^{6}$

Costumo dizer a meus alunos de métodos e técnicas de pesquisa que delimitar um objeto de estudo é como lapidar uma pedra preciosa: é preciso não ter pena de perder lascas, pois o valor final da pedra resultará da arte de alcançar e destacar sua parte mais bela, ou seja, o que se perde é, na verdade, um ganho. Mas falar é sempre mais fácil do que fazer.

\section{- Trabalho de campo e reflexões teórico-metodológicas: recíprocas influências}

Durante, aproximadamente, 4 anos - 1997, 1998, 1999 e 2001 —, em meio, portanto, à "lapidação teórico-metodológica" do projeto original, transitei pelos cinco Tribunais do Júri de São Paulo. Embora, em momento algum, tenha havido a intenção de trabalhar com amostras estatísticas das sessões ocorridas nesse período, orientei minhas visitas aproximando-as ao máximo do volume anual de julgamentos realizados em cada Tribunal.

Minha rotina de trabalho, inicialmente estimada, foi a seguinte:

\begin{tabular}{|c|c|c|c|c|c|c|}
\hline Tribunais $\rightarrow$ & $\mathbf{1}^{\circ}$ & $\mathbf{2}^{\circ}$ & $\mathbf{3}^{\circ}$ & $\mathbf{4}^{\circ}$ & $\mathbf{5}^{\circ}$ & Totais \\
\hline $\begin{array}{c}\mathrm{n}^{\circ} \text { máximo } \\
\text { aproximado de } \\
\text { julgamentos/mês }\end{array}$ & $\begin{array}{c}160 \\
(54 \%)\end{array}$ & $\begin{array}{c}40 \\
(13 \%)\end{array}$ & $\begin{array}{c}40 \\
(13 \%)\end{array}$ & $\begin{array}{c}40 \\
(13 \%)\end{array}$ & $\begin{array}{c}20 \\
(7 \%)\end{array}$ & $\begin{array}{c}\mathbf{3} \% 00 \\
(100 \%)\end{array}$ \\
\hline $\begin{array}{c}\mathbf{n}^{\circ} \text { aproximado } \\
\text { de visitas/mês }\end{array}$ & $\mathbf{4}$ ou $\mathbf{5}$ & $\mathbf{1}$ & $\mathbf{1}$ & $\mathbf{1}$ & $\begin{array}{c}\mathbf{0 . 5} \\
\text { (mês sim, } \\
\text { mês não) }\end{array}$ & $\begin{array}{c}\mathbf{8} \\
\text { (2/semana) }\end{array}$ \\
\hline
\end{tabular}

$\Rightarrow$ Esses cálculos levaram em conta o número de plenários existentes, em 1997, em cada Tribunal do Júri $8,2,2,2,1$, respectivamente - e o fato de que, em cada plenário poderia haver até um julgamento por dia útil (aproximadamente 20 dias/mês).

\footnotetext{
$\overline{6}$ - Aproveito para reiterar que, quando da qualificação, não fossem os comentários metodologica e conceitualmente precisos e cuidadosos da orientadora e dos examinadores - Prof ${ }^{\mathrm{a}}$ Dra Maria Lúcia Montes e Prof. Dr. Sérgio Adorno -, eu não teria dado o salto qualitativo que me permitiu finalizar a tese.
} 
Com base nessas estimativas, o ritmo previsto para a realização da pesquisa de campo, de março a novembro de 1997 e de março a novembro de 1998, foi:

\begin{tabular}{|c|c|c|c|c|c|c|}
\hline Tribunais $\rightarrow$ & $\mathbf{1}^{\circ}$ & $\mathbf{2}^{\circ}$ & $\mathbf{3}^{\circ}$ & $\mathbf{4}^{\circ}$ & $5^{\circ}$ & Totais \\
\hline visitas em 1997 & 36 & 8 & 8 & 8 & 4 & $\mathbf{6 4}$ \\
\hline visitas em 1998 & 36 & 8 & 8 & 8 & 4 & $\mathbf{6 4}$ \\
Total de julgamentos a & $\mathbf{7 2}$ & $\mathbf{1 6}$ & $\mathbf{1 6}$ & $\mathbf{1 6}$ & $\mathbf{8}$ & $\mathbf{1 2 8}$ \\
assistir & $(56 \%)$ & $(13 \%)$ & $(13 \%)$ & $(13 \%)$ & $(5 \%)$ & $(100 \%)$ \\
\hline
\end{tabular}

Em virtude de imprevistos do próprio campo — adiamento de sessões, geralmente por ausência do réu preso ou de seu advogado - e de outros compromissos relacionados às demais atividades da pesquisa — visitas a bibliotecas, entrevistas, cursos etc - o cronograma estimado realizou-se da seguinte maneira:

\begin{tabular}{|c|c|c|c|c|c|c|}
\hline Tribunais $\rightarrow$ & $\mathbf{1}^{\circ}$ & $\mathbf{2}^{\circ}$ & $\mathbf{3}^{\circ}$ & $\mathbf{4}^{\circ}$ & $\mathbf{5}^{\circ}$ & Totais \\
\hline visitas em 1997 & 25 & 5 & 6 & 5 & 3 & $\mathbf{4 4}$ \\
\hline visitas em 1998 & 23 & 5 & 5 & 7 & 2 & $\mathbf{4 2}$ \\
\hline $\begin{array}{c}\text { Totais de julgamentos } \\
\text { assistidos }\end{array}$ & $\mathbf{4 8}$ & $\mathbf{1 0}$ & $\mathbf{1 1}$ & $\mathbf{1 2}$ & $\mathbf{5}$ & $\mathbf{8 6}$ \\
$(56 \%)$ & $(12 \%)$ & $(13 \%)$ & $(14 \%)$ & $(5 \%)$ & $(100 \%)$ \\
\hline
\end{tabular}

Durante o $1^{\circ}$ semestre de 1999 e ao longo de 2001, assisti a mais algumas sessões -7 e 14, respectivamente - todas no $1^{\circ}$ Tribunal do Júri, totalizando, assim, 107. Essa decisão decorreu de dois motivos: da necessidade de complementar observações, à medida que o texto final da tese ganhava corpo, e devido ao fato de o $1^{\circ}$ Tribunal ter-se mudado de endereço, no final de 1999, parecendo-me prudente conhecer e analisar seus novos plenários.

Enfim, apesar de não haver uma proposta rigorosa e estatística de freqüentar os Tribunais, com vistas a generalizar conclusões, o resultado do trabalho de campo permite afirmar que esta tese aborda, qualitativamente, sessões de Júri realizadas nos cinco Tribunais paulistanos, durante os anos de 1997, 1998, 1999 e 2001.

\begin{tabular}{|c|c|c|c|c|c|c|}
\hline Tribunais $\rightarrow$ & $\mathbf{1}^{\circ}$ & $\mathbf{2}^{\circ}$ & $\mathbf{3}^{\circ}$ & $\mathbf{4}^{\circ}$ & $\mathbf{5}^{\circ}$ & Total \\
\hline julgamentos assistidos em & 69 & 10 & 11 & 12 & 5 & 107 \\
$1997,1998,1999$ e 2001 & $(65 \%)$ & $(9 \%)$ & $(10 \%)$ & $(11 \%)$ & $(5 \%)$ & $(100 \%)$ \\
\hline
\end{tabular}

O que mais importa em relação a esses números, todavia, não é a quantidade de sessões assistidas (107) e sim a relevância que o conjunto formado por elas teve na construção da problemática da tese, das estratégias metodológicas e das redefinições do enfoque teórico. $\mathrm{O}$ fato de o trabalho de campo ter-se desenvolvido ao longo de quase todo o doutorado permitiu que a coleta de dados empíricos não se dissociasse das 
reflexões teórico-metodológicas e vice-versa, havendo uma recíproca influência entre elas.

O primeiro $1 / 4$ das 107 sessões serviu-me, antes de tudo, para "apurar" uma sensibilidade em relação ao Júri ou, usando um trocadilho, para eu perceber o que era importante perceber. Como acontece com quase todos os antropólogos em seus trabalhos de campo, passei por um período de adaptação, durante o qual, pouco a pouco, aprendi a estranhar o familiar e a familiarizar-me com o estranho, tanto que, hoje, revendo as primeiras sessões registradas em meus cadernos de campo e comparando-as às últimas, noto o quanto transformei meu modo de percebê-las, à medida que se refinava a problemática teórica e vice-versa.

Nas primeiras sessões, eu não sabia, ao certo, o que observar e, portanto, observava tudo o que podia, indistintamente. Relendo essas anotações, percebo que a mesma quantidade de páginas preenchidas com observações de como eram os espaços exteriores aos plenários (corredores, cartório, gabinetes de juízes, promotores e advogados) eu também preenchi com registros do espaço interno (disposição e tipo de mobiliário, luminosidade, cores das paredes, do piso, dizeres das placas) e também com a dinâmica das sessões.

Esse excesso inicial de informações, aparentemente caóticas, resultante da falta de critérios que me permitissem depurar o que chegava em estado bruto aos meus sentidos, foi, contudo, o que me possibilitou, ao final do primeiro ano de trabalho de campo, rever o projeto original da tese.

São três os cadernos de campo em que o andamento da pesquisa está registrado, cronologica e "evolutivamente", mas trabalhar esse material empírico implicou, justamente, subverter essas seqüências, impondo-lhe outras. Trechos de diferentes conversas, descrições de vários espaços, de muitos rostos, gestos, olhares, sorrisos e lágrimas, ruídos, tumultos e vazios, registros, enfim, do que é difícil traduzir em palavras - ainda mais em palavras para uma tese de doutorado - passaram por uma espécie de assepsia para caberem no esqueleto limpo e estruturado do texto acadêmico. Portanto, os vários trechos de sessões e entrevistas que preenchem esta tese, sob a forma de citações exemplares, estão, por um lado, desconectados de seus encadeamentos cronológicos e de detalhes de seus contextos originais, mas, por outro, passaram a integrar novas seqüências argumentativas porque eles próprios, somados e em interação, levaram a elas. 
Cabe relembrar que, como não é permitido gravar o transcorrer das sessões de julgamento pelo Júri, seja em fita K-7 ou em vídeo, todos os trechos de falas transcorridos em plenário e nas salas secretas anotei, nos cadernos de campo, valendo-me de uma espécie de taquigrafia. Quanto às entrevistas realizadas fora dos plenários, quase todas foram gravadas em fitas $\mathrm{K}-7$, com o consentimento dos entrevistados, mediante a garantia de que suas identidades seriam resguardadas. Entrevistei, em cada um dos cinco Tribunais do Júri:

\begin{tabular}{|l|c|}
\hline Entrevistas em cada Tribunal & Total de entrevistas nos 5 Tribunais \\
\hline$\bullet$ 1 juiz presidente & 5 \\
\hline$\bullet$ 1 juiz auxiliar & 5 \\
\hline$\bullet$ 2 promotores & 10 \\
\hline - 2 defensores & 10 \\
\hline 2 ré(u)s & 10 \\
\hline - assistentes - familiares de réus, & 13 \\
\hline estagiários de direito & 52 \\
\hline - jurados & $\mathbf{1 0 5}$ \\
\hline \multicolumn{1}{|c|}{ Total de entrevistados } & (aproximadamente 30 horas) \\
\hline
\end{tabular}

No caso dos jurados, embora sem intenção de alcançar fidedignidade estatística, levei em conta a proporção do número de inscritos em cada Júri, de acordo com a seguinte tabela:

\begin{tabular}{|c|c|c|c|c|c|c|}
\hline Tribunais $\rightarrow$ & $1^{0}$ & $2^{\circ}$ & $3^{\circ}$ & $4^{\circ}$ & $5^{\circ}$ & Total \\
\hline $\begin{array}{l}\text { total aprox. } \\
\text { de inscritos } \\
\text { (1997) }\end{array}$ & $\begin{array}{c}10.000 \\
(54,0 \%)\end{array}$ & $\begin{array}{c}2.400 \\
(13,0 \%)\end{array}$ & $\begin{array}{c}2.400 \\
(13,0 \%)\end{array}$ & $\begin{array}{c}2.400 \\
(13,0 \%)\end{array}$ & $\begin{array}{l}1.250 \\
(7.0 \%)\end{array}$ & $\begin{array}{l}18.450 \\
(100 \%)\end{array}$ \\
\hline
\end{tabular}

\begin{tabular}{|c|c|c|c|c|c|c|}
\hline $\begin{array}{c}\text { entrevistas } \\
\text { estimadas }\end{array}$ & 27 & 7 & 7 & 7 & 2 & 50 \\
\hline $\begin{array}{c}\text { entrevistas } \\
\text { realizadas }\end{array}$ & 35 & 4 & 6 & 5 & 2 & 52 \\
\hline
\end{tabular}

Além de o total dessas entrevistas não permitir quaisquer análises quantitativas percentualizações e generalizações de resultados - não segui um roteiro único e estruturado de perguntas, preferindo privilegiar, em cada situação, aquilo que o contexto melhor propiciava para debate. Minhas perguntas, portanto, apesar de sempre buscarem significações que jurados, promotores, defensores, testemunhas, réus, juízes etc davam a ocorrências do desenrolar das sessões, variaram de acordo com as sutilezas dessas 
ocorrências em cada julgamento. O mais importante, contudo, é destacar que os conceitos de jogo, ritual e drama, ainda que com significados advindos do senso comum, surgiram, de forma recorrente, em várias entrevistas e argüições, alertando-me para a possibilidade de trabalhá-los teoricamente e permitindo-me estruturar as últimas entrevistas em função deles.

Enfim, os dados empíricos que compõem esta tese tiveram papel importante na definição de seus contornos teóricos e vice-versa, pois, a coleta dos primeiros redimensionou problemas e hipóteses e esses, por sua vez, orientaram meu olhar sobre o objeto. O amadurecimento do projeto inicial deu-se em função dessa recíproca influência. Daí, dentre outras razões, a relevância, num capítulo metodológico, de se registrar o caminho percorrido, sem omitir trajetos desfeitos e abandonados, pois todos, geralmente, têm peso no resultado final.

\section{- Lascas da lapidação: sementes para outras pesquisas?}

Dentre as fontes de dados que, em algum momento do trabalho, cheguei a considerar, mas acabei desprezando, destacam -se a produção jurisprudencial recente sobre o Júri brasileiro, reportagens e artigos publicados pelo jornal Folha de S. Paulo, estatísticas elaboradas pela Secretaria dos Negócios da Segurança Pública do Estado de São Paulo e pela FSEADE, além dos longa-metragens norte-americanos e ingleses sobre Júri mais alugados nas principais videolocadoras da cidade. Embora eu não tenha levado a cabo a utilização dessas fontes, por referirem-se, conforme já foi dito, a discursos da sociedade sobre o Júri e não a discursos do Júri sobre a sociedade, elas podem ser de interesse para futuras pesquisas.

7 - Cabe registrar que, além de serem pouquíssimos, no Brasil, os estudos sociojurídicos empíricos sobre Júri, menos ainda são aqueles baseados em - ou que fazem uso de - entrevistas a jurados e demais participantes do Júri. Conforme já mencionamos, destacase o trabalho realizado pelo Dr. Guilherme de Souza Nucci, junto a 574 jurados do $3^{\circ}$ Tribunal do Júri de São Paulo (Nucci, 1999: 219-363). Referencial, também, é uma pesquisa que analisou todas as listas de jurados, processos julgados pelo Júri e notícias de jornais a eles referentes, desde o surgimento da comarca de Americana (SP) - 1954 - até 1994. Nesse estudo foram realizadas entrevistas com profissionais que participaram dos julgamentos e com jurados, com vistas a entender a inserção de mulheres no Conselho de Sentença (Fontolan, 1994: 67-88). No Rio Grande do Sul, Lênio Streck investigou duas comarcas - Rio Pardo, pobre e de imigração portuguesa, e Santa Cruz do Sul, rica e de imigração alemã - para confrontar o que ele chamou de "índole e ideologia" dos jurados. Concluiu que na $1^{\mathrm{a}}$ havia muito mais absolvições $-72,32 \%$ - do que na $2^{\mathrm{a}}-31,23 \%$ - e que, portanto, a "índole da comunidade lusa" facilitava o esquecimento e o perdão das infrações cometidas, enquanto a "índole da comunidade germânica" revelava rigidez na observância no cumprimento de regras de conduta (Streck,1998: 87 e ss). 
Especialmente nos dois primeiros anos de doutorado (1996-1997), examinei vários livros que tratavam do Tribunal do Júri no Brasil e encontravam-se disponíveis nas principais bibliotecas jurídicas de São Paulo e/ou nas principais livrarias da cidade. Assim como ocorreu com as 107 sessões de julgamento assistidas, várias idéias decorrentes dessas leituras não foram aproveitadas diretamente na tese, mas orientaram-na e estão em seu subtexto.

Quase invariavelmente, na maioria dos livros jurídicos que tratam do Júri, em algum item ou capítulo, os autores fazem um breve "histórico" da instituição, apontando suas origens na antigüidade clássica greco-romana - séc. IV a.C. ${ }^{8}$-, na Palestina (Nucci, 1999: 31), na "noite dos tempos" 9 ou até na "Santa Ceia" ${ }^{10}$ para, em seguida, referirem-se à Magna Carta (Inglaterra, 1215) e atribuírem a esse "momento histórico" as "feições modernas do Júri". A partir dessa gênese, costumam saltar para o século XV, mencionando que, durante esse largo intervalo, a instituição "modelou-se" e espraiou-se pelo Ocidente (Nucci, 1999: 32). Desse ponto da cronologia, vários autores passam para a chegada do Júri no Brasil, em 1822, criado para julgar crimes de imprensa. Seguem, então, uma seqüência cronológico-legal das constituições brasileiras e decretos que alteraram a competência do Júri e finalizam a maioria desses "históricos", concluindo ou pelo atual "caráter democrático" - garantidor de direitos e garantias individuais — ou "anti-democrático" do Júri brasileiro - perpetuador de discriminações sociais, econômicas e políticas. Tanto num caso quanto em outro, o Júri parece ser tomado como uma espécie de termômetro da democracia brasileira sem, contudo, discutir-se os diversos contextos sócio-políticos pelos quais passou o país, bem como os diferentes perfis de legisladores envolvidos nas discussões e definições a respeito da competência do Júri e mesmo do que se entende por "sociedade", "democracia" e "cultura brasileira".

Após constatar o quanto se repetia esse modelo de "histórico do Júri" nos livros doutrinários sobre o Júri no Brasil, propus-me a analisar como a maioria dos autores - os mais lidos por alunos e profissionais do direito - faziam essa "história do Júri". No relatório apresentado para o exame de qualificação, elaborei a hipótese de que, para esses formadores de novos profissionais do direito no Brasil, a cronologia das leis e a seqüência de suas alterações são percebidas como registros históricos dos caminhos e descaminhos - da democracia no país. Em outras palavras, a meu ver eles sugerem —

\footnotetext{
8 - ALMEIDA, Dario Martins de - O livro do jurado. Coimbra, Livraria Almedina, 1977, pg. 135.

9 - BONAVIDES, Paulo - Curso de Direito Constitucional. São Paulo: Malheiros, 1997, pg.156.

10 - SOARES, Orlando - Curso de direito processual penal. Rio de Janeiro: José Konfino Editor, 1977, pg. 311.
} 
ainda que sem necessariamente desenvolver a fundo a sugestão - a validade de uma abordagem legalista da história. Porém, como, a partir da qualificação, não só me distanciei da discussão sobre o "caráter democrático" do Júri, mas de todas as fontes que, para além dos plenários, tratavam da instituição, deixei de lado a leitura desses "históricos doutrinários".

Outra fonte de dados que, inicialmente, considerei válida e, depois, desprezei, foram notícias sobre Júri veiculadas pela mídia - programas televisivos, imprensa escrita, programas de rádio etc. Considerei, num primeiro momento, que tais fontes poderiam, em alguma medida, influenciar os discursos elaborados durante as sessões de Júri e vice-versa.

Comecei por investigar notícias veiculadas pelo jornal Folha de S. Paulo, entre $1^{\circ}$ de janeiro de 1994 e 31 de dezembro de 1998. Valendo-me dos textos integrais, disponíveis em CD-ROM, de todas as edições desse período, elaborei um formulário ${ }^{11}$ para analisar as notícias, mês a mês, segundo algumas variáveis. Tal análise deu-me uma idéia dos casos que, para esse jornal, foram paradigmáticos, tanto que sugeri à banca de qualificação que eles poderiam fornecer elementos complementares e relacionados à discussão dos significados em jogo no ritual de julgamentos pelo Júri.

Embora tendo praticamente concluído a análise dessas notícias e selecionado alguns casos "paradigmáticos"12, abandonei esse material, após o exame de qualificação, pois concordei com os examinadores quanto à desproporção entre os esforços que ainda restariam empreender para fazer um adequado uso dessas fontes e a contribuição que elas poderiam dar à análise do caráter lúdico, ritual e dramático do Júri. Novamente, tratava-se de uma fonte de discursos sobre o Júri, não provenientes de sua dinâmica interna. Ficou-me claro, também, que quando promotores, defensores e juízes, no transcorrer dos julgamentos, faziam uso de notícias veiculadas pela mídia, o que mais importava não era verificar a propriedade desses usos, mas analisar seus significados nos próprios contextos discursivos.

\footnotetext{
11 - Anexo 6.

12 - Em relação a 1995, por exemplo, selecionei o julgamento de O. J. Simpson, nos Estados Unidos, pois de um total de 237 notícias sobre Júris publicadas ao longo daquele ano, 34\% trataram desse caso. Nesse mesmo ano, consequentemente, notícias sobre julgamentos por Júris estrangeiros superaram as referentes a Júris no Brasil (57\% e $43 \%$, respectivamente). Consideradas só as primeiras, o "caso O. J." respondeu por 60\% delas. Com base nesses dados, levantei a hipótese de que leitores desse jornal, interessados em Júri, durante 1995, teriam recebido muito mais informações sobre o ritual americano do que sobre o brasileiro - tanto que a editoria do Caderno Mundo, sozinha, produziu $46 \%$ de todas as notícias em questão.
} 
Pelos mesmos motivos, perdeu o sentido investir esforços no levantamento e análise de dados estatísticos policiais e judiciais a respeito de homicídios registrados no município de São Paulo - número de ocorrências, inquéritos instaurados, processos e sentenças condenatórias e absolutórias proferidas pelos cinco Tribunais do Júri ${ }^{13}$. Era minha intenção original elaborar, num mapa do município de São Paulo — segundo áreas de circunscrição das delegacias de polícia, agrupadas, por sua vez, segundo o Tribunal do Júri a que remetem seus inquéritos policiais - a distribuição das ocorrências e de inquéritos de homicídios, tornando visível uma macrovisão geo-referenciada da competência de cada Tribunal e dos resultados que vêm produzindo.

Como em vários momentos das sessões de Júri — depoimentos de delegados, de policiais militares e civis, argumentos e contra-argumentos de defensores e promotores, intervenções de juízes - estatísticas criminais eram mencionadas, considerei que valeria a pena pesquisá-las em suas fontes primárias. Porém, mais uma vez, graças às sugestões dos examinadores, quando da qualificação, foi-me possível perceber que, somente na representação cênica das estatísticas elas ganhavam os significados que me interessava analisar, bastando-me, portanto, atentar para tais representações e significados, deixando de lado questões como: $O$ que os mais recentes dados estatísticos apontam sobre os crimes de competência do Júri? Passei, assim, a considerar outras questões: Como e por que advogados e promotores utilizam estatísticas em suas argüições nos plenários do Júri? Que efeitos pretendem produzir e produzem com tais utilizações?

$\sigma$

Outra estratégia de pesquisa pensada, mas não levada a cabo, referia-se à filmografia sobre Júri disponível e mais procurada nas principais videolocadoras da cidade. O motivo de eu, originalmente, ter pensado em analisar esse material, decorreu do fato de que, ao conversar sobre o Júri brasileiro, com várias pessoas sem formação jurídica e mesmo com algumas formadas em direito - não ocupadas na área penal -, a maioria revelou ter uma imagem dessa instituição muito pautada no modelo norte americano ou inglês, devido a filmes a que haviam assistido. Pareceu-me, portanto, relevante analisar quais filmes eram esses e que mensagens eles mais veiculavam a respeito do Júri, pois, minha hipótese era a de que o conhecimento prévio de vários

13 - Fontes: Secretaria da Segurança Pública (SSP), Delegacia Geral de Polícia (DGP), Departamento de Planejamento e Controle da Polícia Civil (DEPLAN), Centro de Análise de Dados (CAD) e Fundação Estadual Análise de Dados Estatísticos (FSEADE). 
jurados a respeito de seu papel e de como deveriam desempenhá-lo advinha, ao menos em parte, dessa filmografia.

Uma de minhas primeiras constatações foi a de que, dentre uma grande variedade temática de filmes disponíveis em várias videolocadoras de São Paulo, os que incluiam julgamentos realizados por Tribunais do Júri nos Estados Unidos estavam dentre os mais alugados. Segundo funcionários de algumas videolocadoras visitadas, havia verdadeiras legiões de fãs de filmes jurídicos, de julgamento, de tribunal, ou de Júri.

Cheguei a realizar um levantamento preliminar, entre março e abril de 99, dos títulos mais procurados. Como eram muitas as videolocadoras da cidade, escolhi a maior rede delas - Blockbuster - e, de posse dos endereços e telefones das 30 lojas então existentes, selecionei intencionalmente cinco, cuidando para que cada uma estivesse em bairros correspondentes às cinco circunscrições dos cinco Tribunais do Júri da capital. Visitei as cinco lojas e, nelas, consultando o gerente ou outro funcionário por ele indicado, perguntei se a loja dispunha de algum registro estatístico, semanal ou mensal, dos vídeos mais locados. O que mais se aproximou de tal levantamento, nas cinco lojas, foi uma revista mensal, de publicação da própria Blockbuster, com uma seleção dos títulos mais cotados, na rede, a cada mês, o que só permitia, contudo, uma vaga noção de, se dentre esses, algum abordava julgamentos pelo Júri. Minha pergunta seguinte aos funcionários era: "Quais filmes norte-americanos ou ingleses sobre julgamentos pelo Tribunal do Júri mais têm sido alugados nessa loja?" Ao registrar as respostas, eu considerava a ordem de citação dos títulos como indicadora de sua relevância, sempre insistindo para que o funcionário mencionasse "todos" os mais alugados. Cruzando informações, os dez filmes indicados como os mais alugados, naquelas lojas e naqueles meses, foram:

$$
\begin{aligned}
& \Rightarrow \text { Doze homens e uma sentença } \\
& \Rightarrow \text { Advogado do Diabo } \\
& \Rightarrow \text { Tempo de matar } \\
& \Rightarrow \text { O homem que fazia chover } \\
& \Rightarrow \text { Assassinato em } 1^{\circ} \text { grau } \\
& \Rightarrow \text { Sleepers } \\
& \Rightarrow \text { Segredos de um Crime } \\
& \Rightarrow \text { O segredo } \\
& \Rightarrow \text { Julgamento final } \\
& \Rightarrow \text { Justa causa }
\end{aligned}
$$


Aproveitando uma oportunidade, analisei a opinião de 57 alunos de direito a respeito do filme Doze Homens e uma Sentença ${ }^{14}$ e cheguei a utilizar, em algumas entrevistas com jurados e operadores técnicos, certos elementos de tensão desse e dos demais filmes, com o intuito de fomentar debates e posicionamentos.

Eu tinha, ainda, outras intenções quanto a estratégias metodológicas de utilização desses filmes - debatê-los com grupos de jurados e operadores técnicos -, mas estas idéias, também no exame de qualificação, foram discutidas e descartadas frente aos rumos que a tese estava tomando, especialmente frente ao enfoque cada vez mais centrado na dinâmica lúdica, ritual e cênica do que se passa nos plenários, durante as horas de julgamento.

Vale ainda registrar que uma das primeiras idéias que me ocorreu ao decidir estudar os Tribunais do Júri de São Paulo foi a de, seguindo o exemplo da estratégia adotada por Maria Alice T. Sestini, em seu mestrado (1979), tornar-me jurada, o que, provavelmente, não seria difícil, pois, por indicação de algum professor da Faculdade de Direito, eu acabaria incluída na lista de jurados do ano seguinte e, em algum momento, seria sorteada para compor o Conselho. Quais seriam, todavia, as implicações de estudar o ritual do Júri ocupando uma posição tão definida?

Refleti, bastante, a respeito, e concluí que, embora ficar na posição de "platéia" também fosse assumir uma posição definida, eu a considerava melhor do que qualquer outra, pois nela eu não participaria diretamente do centro da cerimônia e, por isso mesmo, poderia observá-la e registrá-la com maior liberdade. Hoje, terminado o trabalho, até penso que poderia ter combinado as duas possibilidades - a de ser jurada e a de compor a platéia-, uma vez que não são excludentes.

Enfim, todas as escolhas implicam perdas e ganhos e quase nunca é fácil o processo que leva à decisão. No caso da seleção de técnicas adotadas numa pesquisa, parece-me tão importante quanto a apresentação dos resultados uma exposição crítica de como chegou-se a eles, pois não se deve perder de vista que as limitações e potencialidades do trabalho intelectual residem nesse processo decisório. Talvez nesse ponto resida a maior semelhança entre um pesquisador e um juiz: ambos precisam decidir e sabem que suas decisões poderiam ser outras, bem como os desdobramentos que

\footnotetext{
$\overline{14}$ - Tal "pesquisa de opinião" foi realizada junto a alunos de $1^{\circ}$ e $3^{\circ}$ anos da PUC-SP, em agosto de 2001, sob a orientação da Prof ${ }^{a}$ Dra Sílvia Pimentel, a quem especialmente agradeço por me ceder o material para análise.
} 
delas decorrem, caso a composição dos elementos da escolha fosse distinta. O que geralmente se tenta é fazer o mais adequado, frente às circunstâncias que se apresentam e a alguns valores compartilhados pela comunidade da qual se participa.

\section{- É lúdico o modo de se "fazer ciência", atualmente?}

Huizinga, conforme já mencionamos, sugere que a realização de uma tese acadêmica equipara-se a jogos solitários de destreza e aplicação - como os quebracabeças, charadas, jogos de armar, paciências, tiro-ao-alvo —, ou seja, o pesquisador "joga" consigo mesmo, embora respeitando regras de sua comunidade científica, pois são elas que garantem a aceitação do resultado final.

Apesar dessa constatação, após reenumerar certas características gerais do jogo - limitação temporal; falta de contato com qualquer realidade exterior a si mesmo; finalidade contida em sua própria realização; consciência de se tratar de uma atividade agradável, a qual proporciona um relaxamento das tensões da vida quotidiana Huizinga afirma que "Nada disso pode ser aplicado à ciência" (Huizinga, 1980: 226).

Para justificar tal afirmação, ele diferencia a ciência "pura" da "aplicada", considerando a segunda a que mais se afasta de uma atividade lúdica, por procurar manter contato com a realidade e, portanto, ter uma temporalidade que não é só sua e finalidades que a extrapolam. Não bastasse isso, Huizinga aponta que as regras da ciência moderna são constantemente alteradas diante de experimentos, o que, num jogo, implica "estragá-lo". Enfim, afirmar que fazer ciência equipara-se a um jogo é, na opinião desse autor, demasiado fácil e deve ser provisoriamente descartado.

Todavia, Huizinga não ttubeia ao apontar as origens da ciência e da filosofia na esfera agonística e a concluir: “(...)é legítimo perguntar se não há na ciência um elemento lúdico, dentro do terreno circunscrito pelo seu método, como por exemplo, na tendência para sistematizar (...)" (op. cit: 226) e também no que diz respeito ao impulso competitivo (idem: 227).

Refletindo a respeito dessas afirmações e, com vistas a finalizar este capítulo, eu diria que esta tese representou, para mim, dentre outras coisas, o desafio de vencer um jogo solitário de destreza e aplicação e, nesse sentido, foi muito lúdica. Por várias vezes, especialmente nos momentos de escrita, retirei-me do cotidiano para lançar-me num tempo e num espaço só meus, nos quais, paradoxalmente, senti angústia e prazer, pois tratava-se de uma competição com meus próprios limites, com as exigências estipuladas pelo Programa de Pós-Graduação e com os parâmetros da comunidade científica. 
Não bastasse isso, por eu ter tomado as próprias sessões de julgamento enquanto situações lúdicas, sistematizá-las, metodologicamente, registrando o próprio processo de sistematização, chegou a ser um jogo de "segunda" e até de "terceira ordem".

E se cabe diferenciar ciência "pura" de ciência "aplicada", talvez, num primeiro momento, tanto aos olhos de profissionais do Direito quanto da Antropologia, esta tese confirmese como lúdica, pois aparenta ser "inaplicável": afinal, não aponta, claramente, encaminhamentos técnicos, políticos e sociais para alguns dos atuais dilemas do Júri no Brasil, como a ampliação, redução ou manutenção de sua competência ou a forma de selecionar jurados ou mesmo a maneira de operadores técnicos conduzirem-se.

Contudo, espero que esta tese tenha uma aplicação e que extrapole seus fins acadêmicos, pois ela não foi escrita apenas para satisfazer meu gosto por jogos solitários de destreza ou para manter-me conforme as regras da comunidade científica. Ela se fez, também, para que especialmente meus colegas da área jurídica talvez se inquietem com o "olhar" que, a partir da Antropologia, é possível lançar sobre o cotidiano de uma de suas instituições. Um olhar que, de fato, não sugere como deve ser o Júri no Brasil, mas que sublina a riqueza cultural que essa instituição concentra e espelha. Ao apresentar o Júri como um jogo, um ritual e um teatro, esta tese pretende apresentar-nos, a nós mesmos, como capazes de elaborar, com grande sofisticação, formas de conhecimento, de julgamento e de controle social. A hipótese subjacente é a de que também somos capazes de elaborar, com igual sofisticação, formas de tornar nossa convivência mais digna. 


\section{CONSIDERAÇÕES FINAIS}

Nestas últimas palavras quero, antes de mais nada, responder diretamente a uma pergunta que muitos me fizeram, ao longo do doutorado, a qual, sempre que pude, não respondi: Afinal, depois de tanta análise, você acha que o Júri deve ou não continuar existindo no Brasil?

Sim, acho que deve. Em primeiro lugar porque, conforme expus nos capítulos $1 \mathrm{e}$ 2, tendo as sessões de julgamento pelo Júri uma natureza essencialmente simbólica e lúdica, e tratando-se de um domínio privilegiado de manifestação de certos desejos e valores culturais, elas representam um recurso a mais para nos conhecermos.

Em segundo lugar e, de acordo com o que está desenvolvido no capítulo 3, o Júri, mais do que um mero espaço de dominação, é um ritual construtor de subjetividades; consequentemente, em seus plenários, tanto podemos produzir e reproduzir preconceitos que ferem os mais básicos direitos humanos quanto podemos elaborar formas de pensar e de decidir que contribuam para o respeito e disseminação desses direitos.

Se é "em cena" e "em ato" que o Júri se faz, enquanto instituição social, é também "em cena" e "em ato" que seus "príncipes" e "súditos" poderão arriscar novas formas de governar e legitimar vidas, pois mortes de seres humanos são sempre ilegítimas.

Enfim, com esta tese - resposta, relativamente longa para a pergunta em questão - espero ter comunicado que considero as sessões de Júri, justamente por incluírem leigos, obras imaginativas tão ou mais ricas do que aquelas que só incluem técnicos.

Por enquanto e depois de tantos anos trabalhando na interface entre as Ciências Sociais e o Direito, era o que eu gostaria de dizer. 


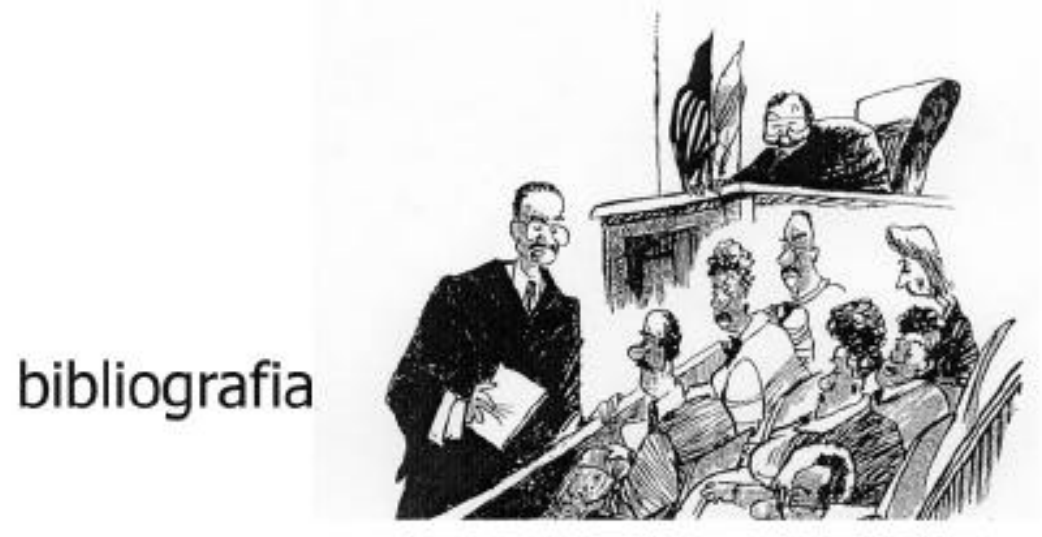




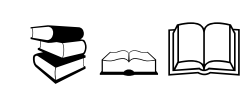

ACQUAVIVA, Marcus Cláudio

— Tribunal do júri. São Paulo: Ícone, 1991.

\section{ADORNO, Sérgio}

- "Crime, justiça penal e desigualdade jurídica: as mortes que se contam no Tribunal do Júri” In Revista USP — Dossiê Judiciário, (21), São Paulo, mar-abr/1994 (pg. 132-151).

\section{ALMEIDA João Batista de}

— Tribunal do Júri. Curitiba: Juruá, 2001.

ANDRADE, Maristela de Paula (org.)

- Justiça privada e tribunal: camponeses no banco dos réus?São Luís: NAV (Núcleo de Apoio a Viúvas de Trabalhadores Rurais Assassinados em Conflitos de Terra) e MPP/UFMA (Mestrado em Políticas Públicas da Universidade federal do Maranhão), 1997.

BALANDIER, Georges

- O Poder em cena. Brasília: Editora UnB, 1982.

\section{BASTIDE Roger}

- "Conseqüências metodológicas" In Sociologia e Psicanálise. São Paulo: Melhoramentos, 1974 (pg. 263-270).

BONFIM, Edílson Mougenot

- "O selecionamento dos jurados, a questão da 'notória idoneidade' e a boa formação do conselho de sentença no tribunal do júri" In Revista dos Tribunais, $n^{\circ}$ 693. São Paulo: Editora Revista dos Tribunais, julho de 1993 (pg. 309-316).

\section{BORGES, Robinson}

- "Licença poética - livro de Steven Lubet afirma que, num julgamento, todo advogado é um contador de histórias" In Jornal Valor, 29 e 30 de junho e $1^{\circ}$ de julho de 2001, pg. 10 e 11). 
BOURDIEU, Pierre

— "O campo científico" In Pierre Bourdieu: sociologia. São Paulo: Ática, 1983 (pg. 122155).

CALDEIRA, Teresa Pires do Rio

— "Uma incursão pelo lado 'não respeitável' da pesquisa de campo" In Ciências Sociais Hoje, vol. 1. Brasília/ Recife: CNPq/ ANPOCS, 1981 (pg. 332 - 354)

- A política dos outros: o cotidiano dos moradores da periferia e o que pensam do poder e dos poderosos. São Paulo: Brasiliense, 1984.

- Cidade de muros: crime, segregação e cidadania em São Paulo. São Paulo: Ed. 34/ Edusp, 2000.

CANCLINI, Néstor García (et al)

- La ciudad de los viajeros - travesías e imaginários urbanos. México: Editorial Grijalbo, 1996.

CARDIA, Nancy

- Pesquisa sobre atitudes, normas culturais e valores em relação a violência em 10 capitais brasileiras. Brasília: Ministério da Justiça. Secretaria dos Direitos Humanos, 1999.

CASTORIADIS, Cornelius

- "La crise du processus identificatoire" In Connexions 55, Malaise dans l'identification. Tolouse, Erès, 1990.

CHALITA Gabriel

- A sedução no discurso. O poder da linguagem nos tribunais de júri. São Paulo: Max Limonad, 1998.

CHARBONNIER, Georges

- Arte, linguagem, etnologia: entrevistas com Claude Lévi-Strauss. Campinas: Papirus, 1989. 
CORRÊA Mariza

- Morte em família: representações jurídicas de papéis sexuais. Rio de Janeiro: Graal, 1983.

DA MATTA, Roberto

- Carnavais, malandros e heróis: para uma sociologia do dilema brasileiro. Rio de Janeiro: Zahar, 1983.

— "Para uma antropologia da tradição brasileira (ou: a virtude está no meio)" e "Os discursos da violência no Brasil" In Conta de mentiroso. Sete ensaios de antropologia. Rio de Janeiro: Rocco, 1994 (pg. 125-149 e 175-197).

- "Uma visão antropológica do caso O J. Simpson" e "Bancando o juiz" In Torre de Babel. Ensaios, crônicas, críticas, interpretações e fantasias. Rio de Janeiro: Rocco, 1996 (pg. 214-216 e 223-225).

DARNTON, Robert

- O grande massacre de gatos e outros episódios da história cultural francesa. Rio de Janeiro: Graal, 1986.

DELMANTO, Dante

- Defesas que fiz no júri. Rio de Janeiro: Renovar, 1996.

- Código Penal comentado. Rio de Janeiro: Renovar, 1988 ( $2^{\mathrm{a}}$ ed.)

\section{DURKHEIM, Èmile}

- Les formes élémentaires de la vie religieuse. Paris: Presses Universitaires de France, 1968.

EWALD, François

— Foucault, a norma e o direito. Lisboa: Veja, 1993.

FAGUNDES, Valda Oliveira

- O discurso no júri. São Paulo: Cortez, 1987. 
FOUCAULT, Michel

- La verdad y las formas juridicas. Barcelona: Gedisa, 1980.

- Microfísica do poder. Rio de Janeiro: Graal, 1974.

FONTOLAN, Tânia

— "A participação feminina no júri" In BRUSCHINI, Cristina \& SORJ, Bila (org.) — Novos olhares: mulheres e relações de gênero no Brasil. São Paulo: Marco Zero/ Fundação Carlos Chagas, 1994 (pg. 67-88).

FREIRE-MAIA, Newton

- A Ciência por dentro. Petrópolis: Vozes, 1991.

GEERTZ, Clifford

— "Um jogo absorvente: notas sobre a briga de galos balinesa" In $A$ interpretação das culturas. Rio de Janeiro: Zahar, 1978 (pg. 278-321) .

— "Afirmação política: espetáculo e cerimónia" In NEGARA: o estado teatro no século XIX. Lisboa: Difel, 1991 (pg. 127-152).

— "O saber local: fatos e leis em uma perspectiva comparativa" In O saber local: novos ensaios em antropologia interpretativa. Rio de Janeiro: Vozes, 1998 (pg. 249-356).

GINZBURG, Carlo

— "O inquisidor como antropólogo" In A micro-história. Lisboa: Difel, 1989 (pg. 203-214).

GUERRA, João Baptista Cordeiro

- $A$ arte de acusar. Rio de Janeiro: Forense Universitária, 1989.

GRISHAN, John

— O júri. Rio de Janeiro: Rocco, 1998.

HASTIE, Reid (et al)

— La institución del jurado en los Estados Unidos: sus intimidades. Madrid: Civitas, 1986. 
HONIGMANN, John J.

"Verbete CERIMÔNIA (ceremony) "In Dicionário de Ciências Sociais. Rio de Janeiro/ Brasília: Fundação Getúlio Vargas/ MEC - Fundação de Assistência ao Estudante, 1986 (pg. 169-170).

HUIZINGA, Johan

- Homo ludens. O jogo como elemento da cultura. São Paulo: Perspectiva, 1980.

KANT de LIMA, Roberto

— "Ordem pública e publica desordem: modelos processuais de controle social em uma perspectiva comparada (Inquérito e jury system) In Anuário Antropológico/88. Brasília: Editora, 1991 (pg. 21 - 44).

- "Bureaucratic rationality in Brazil and in the United States: criminal justice systems in comparative perspective" In HESS, David J. and Da Matta, Roberto A . (ed.) - The Brazilian puzzle: culture on the borderlands of the western word. New York: Columbia University Press, 1993 (pg. 241-269).

- "Aspectos gerais da ideologia jurídica brasileira: a versão brasileira da tradição liberal anglo-americana In A polícia na cidade do Rio de Janeiro: seus dilemas e paradoxos. Rio de Janeiro: Forense, 1995 (pg.143-156).

— "Verbete RITUAL" In Dicionário de Ciências Sociais. Fundação Getúlio Vargas/ MEC Fundação de Assistência ao Estudante, s/ local e s/data da edição (pg. 1081-1082).

KUHN, Thomas

- "A função do dogma na investigação científica" In DEUS, Jorge Dias de (org.) $-A$ crítica da ciência. Rio de Janeiro: Zahar, 1974 (pg. 53-80).

LAGAZZI, Suzy

- O desafio de dizer não. Campinas: Pontes, 1988.

LAPLANTINE, François

- Aprender antropologia. São Paulo: Brasiliense, 1988. 


\section{LEACH, E.}

- "O tempo e os narizes falsos" In Repensando a antropologia. São Paulo: Perspectiva, 1974 (203-209).

- Cultura e comunicação. Rio de Janeiro: Zahar, 1978.

\section{LEMOS, Renato}

- "Evandro Lins e Silva" In Caderno Domingo do Jornal do Brasil, n 1151, 24 de maio de 1998 (pg. 24-29).

\section{LÉVI-STRAUSS, Claude}

- "O feiticeiro e sua magia" In Antropologia estrutural. Rio de Janeiro: Tempo Brasileiro, 1996 (pg. 193-213).

LIMA, Carlos de Araújo

— Os grandes processos do júri (2 vol.). Rio de Janeiro: Lumen Juris, 1996.

LOCHE, Adriana et al

- Sociologia Jurídica. Porto Alegre: Síntese, 1999.

\section{LOPES, José Reinaldo de Lima Lopes}

— "Justiça e poder judiciário ou a virtude confronta a instituição" In Revista USP - Dossiê Judiciário, (21), São Paulo, mar-abr/1994 (pg. 22-33).

\section{LUBET, Steven}

- Nothing but the truth - Why trial lawyers don't, can't and shouldn't have to tell the whole truth. New York: New York University Press, 2001.

MAGGIE, Ynonne

- Medo do feitiço: relações entre magia e poder no Brasil. Rio de Janeiro: Arquivo Nacional, 1992.

MAQUIAVEL, Nicolau

— O príncipe: com notas a Napoleão Bonaparte. São Paulo: Revista dos Tribunais, 1997. 
MARREY, Adriano; FRANCO, Alberto Silva \& STOCCO, Rui

— Teoria e prática do júri. São Paulo: Revista dos Tribunais, 1997.

MARTINS, José de Souza

- "Linchamento, o lado sombrio da mente conservadora"In Tempo Social - Revista de Sociologia da USP, S. Paulo, 8(2): 11-26, outubro de 1996.

MAUSS, Marcel

— "Ensaio sobre a dádiva. Forma e razão da troca nas sociedades arcaicas" In Sociologia e Antropologia, vol. II. São Paulo: EPU. 1984[a] (pg. 37-184).

- "Esboço de uma teoria geral da magia" In Sociologia e Antropologia, vol. I. São Paulo: EPU. 1984[b] (pg. 37-176).

MEYER, Marlise

- Caminhos do Imaginário no Brasil. São Paulo: Edusp, 1993.

MONTERO, Paula

- "Reflexões dobre uma antropologia das sociedades complexas" In Revista de Antropologia, $\mathrm{n}^{\circ}$ 34, São Paulo: USP, 1991 (pg. 103-130).

- "Cultura e democracia no processo da globalização" In Novos Estudos Cebrap, n 44 , São Paulo: Cebrap, março/1996 (pg. 89-114).

NASSIF, Aramis

— Júri: instrumento da soberania popular. Porto Alegre: Livraria do Advogado, 1996.

NUCCI, Guilherme de Souza

- Júri: princípios constitucionais. São Paulo: Juarez de Oliveira, 1999.

\section{OLIVA-AUGUSTO, Maria Helena}

- "O moderno e o contemporâneo: reflexões sobre os conceitos de indivíduo, tempo e morte" In Tempo Social — Revista de Sociologia da USP, S. Paulo, 6(1-2): 91-105, 1994. 
PAIXÃO, Antonio, Luiz (org.)

- Indicadores Sociais de Criminalidade. Belo Horizonte: Fundação João Pinheiro, Centro de Estudos Políticos e Sociais, 1987 (relatório de pesquisa).

PERELMAN, Chaïm

- Ética e Direito. São Paulo: Martins Fontes, 1996.

- Retóricas. São Paulo: Martins Fontes, 1997.

PERELMAN, Chaïm \& OLBRECHTS-TYTECA, Lucie

- Tratado da argumentação: a nova retórica. São Paulo: Martins Fontes, 1996.

PIMENTEL, Manoel Pedro

- "A oratória perante o Júri" In Revista dos Tribunais, n 628. São Paulo: Editora Revista dos Tribunais, fevereiro de 1988 (pg. 281-290).

PIMENTEL, Sílvia; SCHRITZMEYER, Ana Lúcia Pastore e PANDJIARJIAN, Valéria

- Estupro: crime ou "cortesia"? - abordagem sociojurídica de gênero. Porto Alegre: Sérgio Antonio Fabris Editor, 1998 (288 pg.)

RADCLIFFE-BROWN, A. R.

- Estrutura e função na sociedade primitiva. Petrópolis: Vozes, 1973.

- Taboo. Cambridge: Cambridge University Press, 1939. 
RIBEIRO, Renato Janine

- A etiqueta no Antigo Regime. São Paulo: Brasiliense, 1983.

- "O triunfo da vontade" e "In tormento veritas" In Ao leitor sem medo: Hobbes escrevendo contra o seu tempo. São Paulo: Brasiliense, 1984 (pg. 133-212).

- "A política como espetáculo" In Os anos 90: política e sociedade no Brasil. São Paulo: Brasiliense, 1994 [vários autores] - (pg. 31-40).

— "Não há pior inimigo do conhecimento do que a terra firme" In Tempo Social: Revista de Sociologia da USP, vol.11, $\mathrm{n}^{\circ}$ 1, maio, 1999 (pg. 189-195).

- "A sociedade contra o social ou A sociedade privatizada" In $A$ sociedade contra 0 social: o alto custo da vida pública no Brasil. São Paulo: Companhia das Letras, 2000 (pg.19-25).

— "O teatro da política" In Jornal do Brasil - Seção Brasil, 29 de abril de 2001 (pg. 5).

SADEK, Maria Teresa \& ARANTES, R. B.

- "A crise do Judiciário e a visão dos juízes" In Revista USP - Dossiê Judiciário, (21), São Paulo, mar-abr/1994 (pg. 34-45).

SAHLINS, Marshall

- Cultura e razão prática. Rio de Janeiro: Zahar, 1979.

SAFFIOTTI, Hleieth \& ALMEIDA, Suely de

— Violência de gênero - poder e impotência. Rio de Janeiro: Revinter, 1995.

SANTOS, Boaventura de Sousa; LEITÃO, Maria Manuel Marques; PEDROSO, João \& FERREIRA, Pedro Lopes

- "Os tribunais nas sociedades contemporâneas" In Os tribunais nas sociedades contemporâneas: o caso português. Porto: Edições Afrontamento, 1996 (pg. 19-56). 
SCHRITZMEYER, Ana Lúcia Pastore

- Labirintos de um julgamento: etnografia de um tribunal do júri. Caxambu: $13^{\circ}$ Encontro Anual da ANPOCS, paper apresentado no GT Direito e Sociedade, out/1989 (13 pg).

- "Por uma mudança no tempo do Judiciário: percepções sobre seleção, formação e carreira de magistrados da justiça comum do estado de São Paulo" In Revista Brasileira de Ciências Criminais, ano 6, n 24. São Paulo: RT/IBCCRIM, out-dez/1998 (pg.257-268).

- "Das queixas de agressões sexuais às sentenças: um fluxo contínuo de disputas através da linguagem" [Resenha do livro de VARGAS, Joana Domingues - Crimes sexuais e sistema de justiça. São Paulo: IBCCRIM, 2000] In Revista Brasileira de Ciências Sociais, vol. 16, n 46 - junho/2001 (pg.184-186).

— "Julgamentos pelo Tribunal do Júri: um ritual teatralizado e lúdico" In Boletim IBCCRIM. São Paulo: IBCCRIM, n 109, dezembro/2001 (pg. 14-15)

SINHORETTO, Jacqueline

- Os justiçadortes e sua justiça. Linchamentos, costume e conflito. Dissertação de mestrado apresentada ao Programa de Pós-Graduação em Sociologia da Faculdade de Filosofia, Letras e Ciências Humanas da Universidade de São Paulo, fevereiro de 2001.

SMITH, W. Robertson

- The religion of semites: the fundamental institutions. New York: Schoken Books, 1972.

SESTINI, Maria Alice Travaglia

- O tribunal do júri: uma forma de distribuição da justiça. Campinas: tese de mestrado apresentada ao Instituto de Filosofia e Ciências Humanas da Universidade de Campinas, 1979.

SILVA, Evandro Lins e

- A defesa tem a palavra (o caso Doca Street e algumas lembranças). Rio de Janeiro: Aide, 1991.

THOMAS, Louis-Vincent

-- Antropología de la muerte. México: Fondo de Cultura Económica, 1993. 
TREIN, Thales Nilo

- Júri: as linguagens praticadas no plenário. Rio de Janeiro: Aide, 1996.

TUCCI, Rogério Lauria (coord.)

- Tribunal do júri: estudo sobre a mais democrática instituição brasileira. São Paulo: Editora Revista dos Tribunais, 1999.

TURNER, Victor

— O processo ritual - estrutura e antiestrutura. Petrópolis: Vozes, 1974.

VARGAS, Joana Domingues

- Crimes Sexuais e Sistema de Justiça. São Paulo: IBCCRIM, 2000.

WEBER, Max

- "A ciência como vocação" In Ciência e política: duas vocações. Brasília/ São Paulo: Editora Unb/ Cultrix, 1983.

WRIGHT MILLS, C.

— "Do artesanato intelectual" in A imaginação sociológica. Rio de Janeiro: Zahar, 1965 (pg. 211-143).

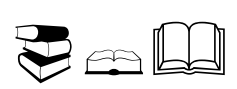




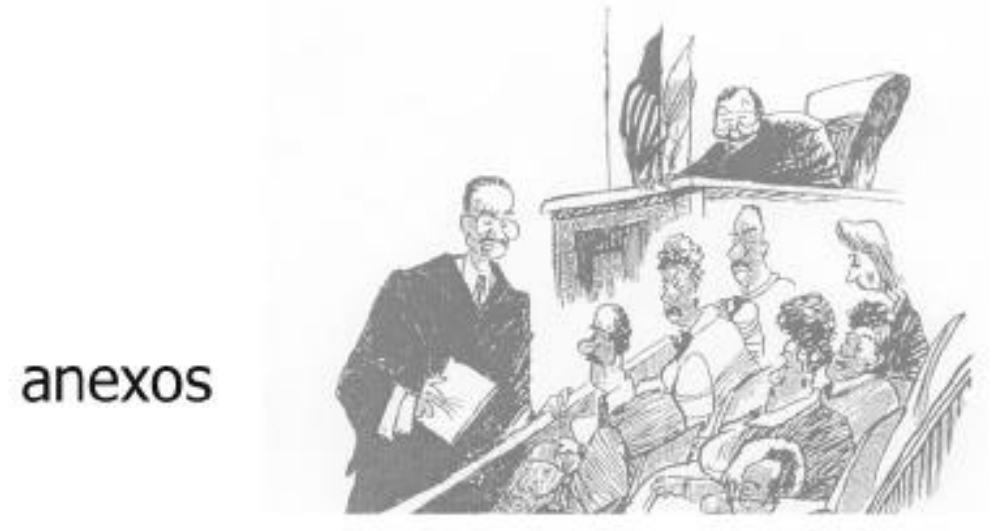




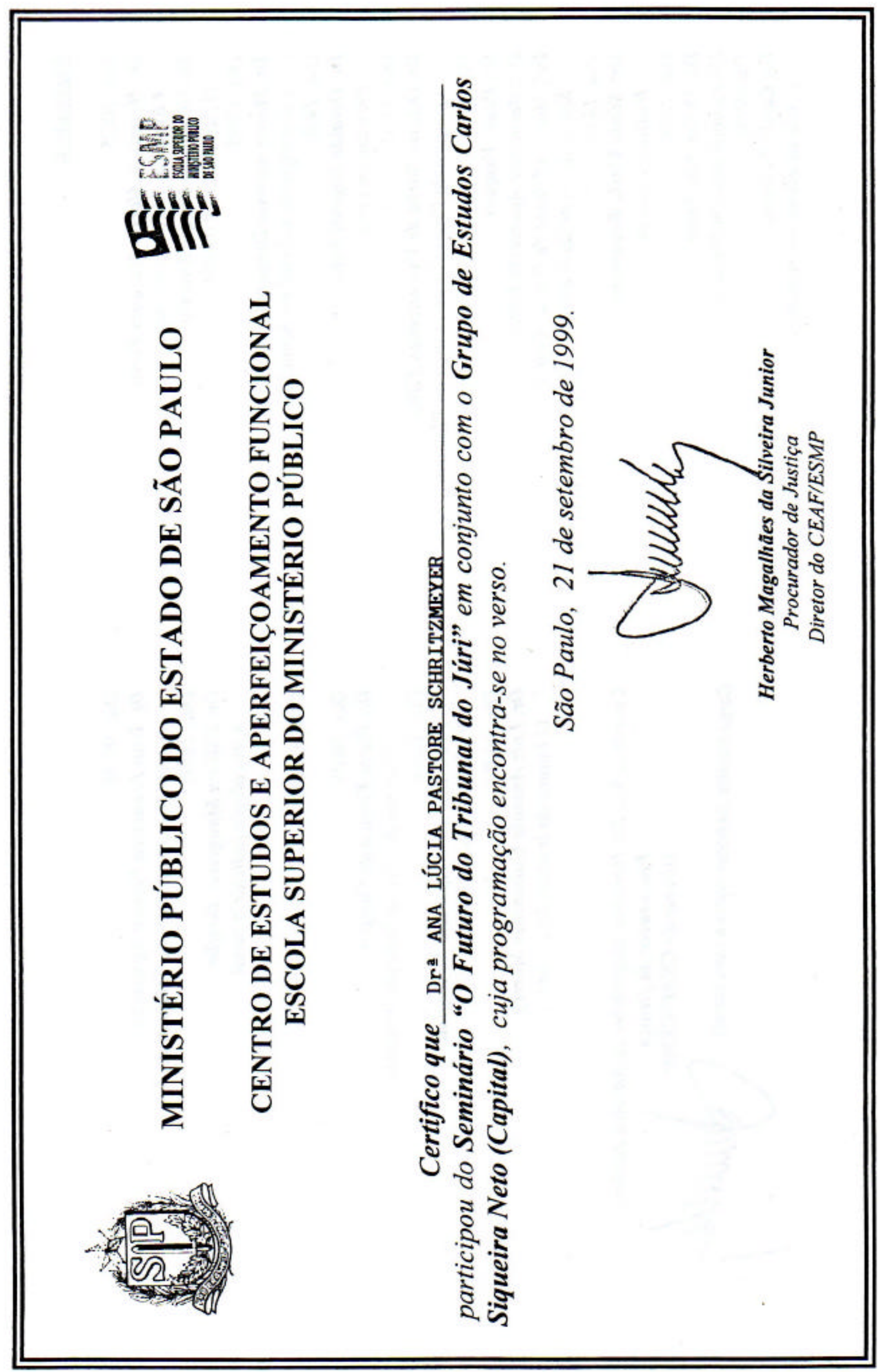



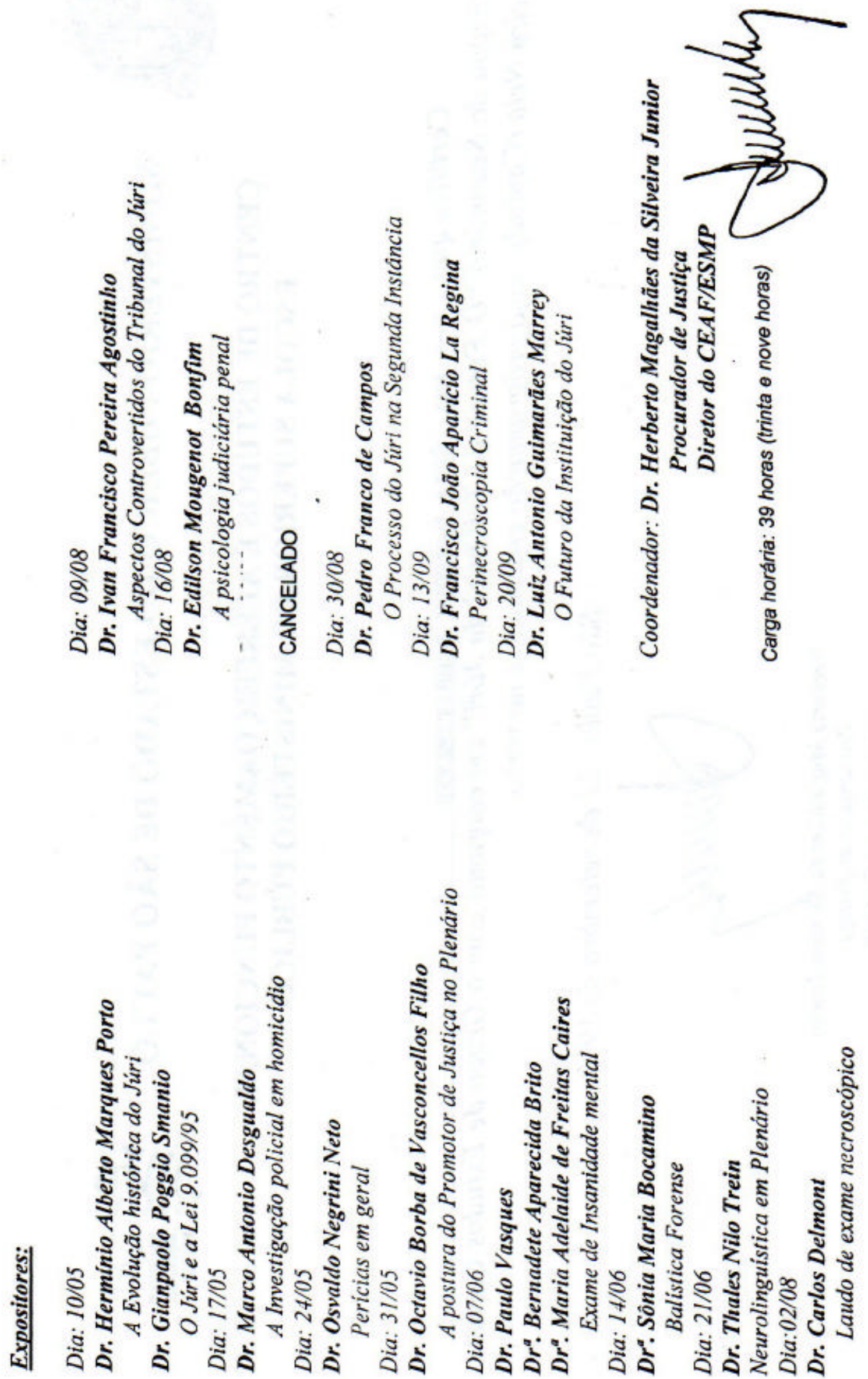
Parágrafo único. Esses prazos começarão a correr depois de findo o tríduo da defesa prévia, ou, se tiver havido desistência, da data do interrogatório ou do dia em que deverá ter sido realizado.

Art. 402. Sempre que o juiz concluir a instrução fora do prazo, consignará nos autos os motivos da demora.

Art. 403. A demora determinada por doença do réu ou do defensor, ou outro motivo de força maior, não será computada nos prazos fixados no art. 401. No caso de enfermidade do réu, o juiz poderá transportar-se ao local onde ele se encontrar, aí procedendo à instrução. No caso de enfermidade do defensor, será ele substituído, definitivamente, ou para o só efeito do ato, na forma do art. 265, parágrafo único.

Art. 404. As partes poderão desistir do depoimento de qualquer das testemunhas arroladas, ou deixar de arrolá-las, se considerarem suficientes as provas que possam ser ou tenham sido produzidas, ressalvado o disposto no art. 209.

Art. 405. Se as testemunhas de defesa não forem encontradas e o acusado, dentro em 3 (três) dias, não indicar outras em substituição, prosseguir-se-á nos demais termos do processo.

CAPÍTULO II

DO PROCESSO DOS CRIMES DA COMPETÊNCIA DO JÚRI

\section{Seçãol}

\section{Da pronúncia, da impronúncia e da absolvição sumária}

Art. 406. Terminada a inquirição das testemunhas, mandará o juiz dar vista dos autos, para alegações, ao Ministério Público, pelo prazo de 5 (cinco) dias, e, em seguida, por igual prazo, e em cartório, ao defensor do réu.

$\S 1^{\circ}$ Se houver querelante, terá este vista do processo, antes do Ministério Público, por igual prazo, e, havendo assistente, o prazo lhe correrá conjuntamente com o do Ministério Público.

$\S 2^{0}$ Nenhum documento se juntará aos autos nesta fase do processo.

Art. 407. Decorridos os prazos de que trata o artigo anterior, os autos serão enviados, dentro de 48 (quarenta e oito) horas, ao presidente do Tribunal do Júri, que poderá ordenar as diligências necessárias para sanar qualquer nulidade ou suprir falta que prejudique o esclarecimento da verdade inclusive inquirição de testemunhas (art. 209), e proferirá sentença, na forma dos artigos seguintes:

Art. 408. Se o juiz se convencer da existência do crime e de indícios de que o réu seja o seu autor, pronunciá-lo-á, dando 
os motivos do seu convencimento. (Redação dada pela Lei $n^{\circ}$ 5.941, de 22.11.1973)

§ 1 $\mathrm{Na}$ sentença de pronúncia o juiz declarará o dispositivo legal em cuja sanção julgar incurso o réu, recomendá-lo-á na prisão em que se achar, ou expedirá as ordens necessárias para sua captura. (Redação dada pela Lei $n^{\circ}$ 9.033, de 2.5.1995)

§ 2 Se o réu for primário e de bons antecedentes, poderá o juiz deixar de decretar-lhe a prisão ou revogá-la, caso já se encontre preso. (Redação dada pela Lei $n^{\circ}$ 5.941, de 22.11.1973)

§ 3ํ Se o crime for afiançável, será, desde logo, arbitrado o valor da fiança, que constará do mandado de prisão. (Redação dada pela Lei $n^{\circ} 5.941$, de 22.11.1973)

§ 4ำ $\bigcirc$ juiz não ficará adstrito à classificação do crime, feita na queixa ou denúncia, embora fique o réu sujeito à pena mais grave, atendido, se for o caso, o disposto no art. 410 e seu parágrafo. (Redação dada pela Lei $n^{\circ}$ 5.941, de 22.11.1973)

§ 5을 Se dos autos constarem elementos de culpabilidade de outros indivíduos não compreendidos na queixa ou na denúncia, o juiz, ao proferir a decisão de pronúncia ou impronúncia, ordenará que os autos voltem ao Ministério Público, para aditamento da peça inicial do processo e demais diligências do sumário. (Parágrafo acrescentado pela Lei $n^{\circ}$ 5.941, de 22.11.1973)

Art. 409. Se não se convencer da existência do crime ou de indício suficiente de que seja o réu o seu autor, o juiz julgará improcedente a denúncia ou a queixa.

Parágrafo único. Enquanto não extinta a punibilidade, poderá, em qualquer tempo, ser instaurado processo contra o réu, se houver novas provas.

Art. 410. Quando o juiz se convencer, em discordância com a denúncia ou queixa, da existência de crime diverso dos referidos no art. $74, \S 1^{\circ}$, e não for o competente para julgá-lo, remeterá o processo ao juiz que o seja. Em qualquer caso, será reaberto ao acusado prazo para defesa e indicação de testemunhas, prosseguindo-se, depois de encerrada a inquirição, de acordo com os arts. 499 e segs. Não se admitirá, entretanto, que sejam arroladas testemunhas já anteriormente ouvidas.

Parágrafo único. Tendo o processo de ser remetido a outro juízo, à disposição deste passará o réu, se estiver preso. 
Art. 411. O juiz absolverá desde logo o réu, quando se convencer da existência de circunstância que exclua o crime ou isente de pena o réu (arts. 17, 18, 19, 22 e 24, § 1ํㅡ, do Código Penal), recorrendo, de ofício, da sua decisão. Este recurso terá efeito suspensivo e será sempre para o Tribunal de Apelação.

Art. 412. Nos Estados onde a lei não atribuir a pronúncia ao presidente do júri, ao juiz competente caberá proceder na forma dos artigos anteriores.

Art. 413. O processo não prosseguirá até que o réu seja intimado da sentença de pronúncia.

Parágrafo único. Se houver mais de um réu, somente em relação ao que for intimado prosseguirá o feito.

Art. 414. A intimação da sentença de pronúncia, se o crime for inafiançável, será sempre feita ao réu pessoalmente.

Art. 415. A intimação da sentença de pronúncia, se o crime for afiançável, será feita ao réu:

I - pessoalmente, se estiver preso;

II - pessoalmente, ou ao defensor por ele constituído, se tiver prestado fiança antes ou depois da sentença;

III - ao defensor por ele constituído se, não tendo prestado fiança, expedido o mandado de prisão, não for encontrado e assim o certificar o oficial de justiça;

IV - mediante edital, no caso do $\mathrm{n}^{\circ} \mathrm{II}$, se o réu e o defensor não forem encontrados e assim o certificar o oficial de justiça;

$\mathrm{V}$ - mediante edital, no caso do $\mathrm{n}^{\circ} \mathrm{III}$, se o defensor que o réu houver constituído também não for encontrado e assim o certificar o oficial de justiça;

VI - mediante edital, sempre que o réu, não tendo constituído defensor, não for encontrado.

$\S 1^{\text {으 }}$ O prazo do edital será de 30 (trinta) dias.

$\S 2^{\circ}$ O prazo para recurso correrá após o término do fixado no edital, salvo se antes for feita a intimação por qualquer das outras formas estabelecidas neste artigo.

Art. 416. Passada em julgado a sentença de pronúncia, que especificará todas as circunstâncias qualificativas do crime e somente poderá ser alterada pela verificação superveniente de circunstância que modifique a 
classificação do delito, o escrivão imediatamente dará vista dos autos ao órgão do Ministério Público, pelo prazo de 5 (cinco) dias, para oferecer o libelo acusatório.

Art. 417. O libelo, assinado pelo promotor, conterá:

I - o nome do réu;

II - a exposição, deduzida por artigos, do fato criminoso;

III - a indicação das circunstâncias agravantes, expressamente definidas na lei penal, e de todos os fatos e circunstâncias que devam influir na fixação da pena;

IV - a indicação da medida de segurança aplicável.

$\S 1^{\circ}$ ํㅡㄹ Havendo mais de um réu, haverá um libelo para cada um.

$\S 2^{\circ}$ Com o libelo poderá o promotor apresentar o rol das testemunhas que devam depor em plenário, até o máximo de 5 (cinco), juntar documentos e requerer diligências.

Art. 418. O juiz não receberá o libelo a que faltem os requisitos legais, devolvendo ao órgão do Ministério Público, para apresentação de outro, no prazo de 48 (quarenta e oito) horas.

Art. 419. Se findar o prazo legal, sem que seja oferecido o libelo, o promotor incorrerá na multa de cinqüenta mil-réis, salvo se justificada a demora por motivo de força maior, caso em que será concedida prorrogação de 48 (quarenta e oito) horas. Esgotada a prorrogação, se não tiver sido apresentado o libelo, a multa será de duzentos mil-réis e o fato será comunicado ao procurador-geral. Neste caso, será o libelo oferecido pelo substituto legal, ou, se não houver, por um promotor ad hoc.

Art. 420. No caso de queixa, o acusador será intimado a apresentar o libelo dentro de 2 (dois) dias; se não o fizer, o juiz o haverá por lançado e mandará os autos ao Ministério Público.

Art. 421. Recebido o libelo, o escrivão, dentro de 3 (três) dias, entregará ao réu, mediante recibo de seu punho ou de alguém a seu rogo, a respectiva cópia, com o rol de testemunhas, notificado o defensor para que, no prazo de 5 (cinco) dias, ofereça a contrariedade; se o réu estiver afiançado, o escrivão dará cópia ao seu defensor, exigindo recibo, que se juntará aos autos.

Parágrafo único. Ao oferecer a contrariedade, o defensor poderá apresentar o rol de testemunhas que devam depor no plenário, até o máximo de 5 (cinco), juntar documentos e requerer diligências. 
Art. 422. Se, ao ser recebido o libelo, não houver advogado constituído nos autos para a defesa, o juiz dará defensor ao réu, que poderá em qualquer tempo constituir advogado para substituir o defensor dativo.

Art. 423. As justificações e perícias requeridas pelas partes serão determinadas somente pelo presidente do tribunal, com intimação dos interessados, ou pelo juiz a quem couber o preparo do processo até julgamento.

Art. 424. Se o interesse da ordem pública o reclamar, ou houver dúvida sobre a imparcialidade do júri ou sobre a segurança pessoal do réu, o Tribunal de Apelação, a requerimento de qualquer das partes ou mediante representação do juiz, e ouvido sempre o procurador-geral, poderá desaforar o julgamento para comarca ou termo próximo, onde não subsistam aqueles motivos, após informação do juiz, se a medida não tiver sido solicitada, de ofício, por ele próprio.

Parágrafo único. O Tribunal de Apelação poderá ainda, a requerimento do réu ou do Ministério Público, determinar o desaforamento, se o julgamento não se realizar no período de 1 (um) ano, contado do recebimento do libelo, desde que para a demora não haja concorrido o réu ou a defesa.

Art. 425. O presidente do Tribunal do Júri, depois de ordenar, de ofício, ou a requerimento das partes, as diligências necessárias para sanar qualquer nulidade ou esclarecer fato que interesse à decisão da causa, marcará dia para o julgamento, determinando sejam intimadas as partes e as testemunhas.

Parágrafo único. Quando a lei de organização judiciária local não atribuir ao presidente do Tribunal do Júri o preparo dos processos para o julgamento, o juiz competente remeter-lhe-á os processos preparados, até 5 (cinco) dias antes do sorteio a que se refere o art. 427. Deverão também ser remetidos, após esse prazo, os processos que forem sendo preparados até o encerramento da sessão.

Art. 426. O Tribunal do Júri, no Distrito Federal, reunir-se-á todos os meses, celebrando em dias úteis sucessivos, salvo justo impedimento, as sessões necessárias para julgar os processos preparados. Nos Estados e nos Territórios, observar-se-á, relativamente à época das sessões, o que prescrever a lei local.

Art. 427. A convocação do júri far-se-á mediante edital, depois do sorteio dos 21 (vinte e um) jurados que tiverem de servir na sessão. O sorteio farse-á, no Distrito Federal, de 10 (dez) a 15 (quinze) dias antes do primeiro julgamento marcado, observando-se nos Estados e nos Territórios o que estabelecer a lei local.

Parágrafo único. Em termo que não for sede de comarca, o sorteio poderá realizar-se sob a presidência do juiz do termo. 
Art. 428. O sorteio far-se-á a portas abertas, e um menor de 18 (dezoito) anos tirará da urna geral as cédulas com os nomes dos jurados, as quais serão recolhidas a outra urna, ficando a chave respectiva em poder do juiz, o que tudo será reduzido a termo pelo escrivão, em livro a esse fim destinado, com especificação dos 21 (vinte e um) sorteados.

Art. 429. Concluído o sorteio, o juiz mandará expedir, desde logo, o edital a que se refere o art. 427, dele constando o dia em que o júri se reunirá e o convite nominal aos jurados sorteados para comparecerem, sob as penas da lei, e determinará também as diligências necessárias para intimação dos jurados, dos réus e das testemunhas.

$\S 1^{\circ}$ O edital será afixado à porta do edifício do tribunal e publicado pela imprensa, onde houver.

$\S 2^{\circ}$ Entender-se-á feita a intimação quando o oficial de justiça deixar cópia do mandado na residência do jurado não encontrado, salvo se este se achar fora do município.

Art. 430. Nenhum desconto será feito nos vencimentos do jurado sorteado que comparecer às sessões do júri.

Art. 431. Salvo motivo de interesse público que autorize alteração na ordem do julgamento dos processos, terão preferência:

I - os réus presos;

II - dentre os presos, os mais antigos na prisão;

III - em igualdade de condições, os que tiverem sido pronunciados há mais tempo.

Art. 432. Antes do dia designado para o primeiro julgamento, será afixada na porta do edifício do tribunal, na ordem estabelecida no artigo anterior, a lista dos processos que devam ser julgados.

\section{Seção II}

\section{Da função do jurado}

Art. 433. O Tribunal do Júri compõe-se de um juiz de direito, que é o seu presidente, e de vinte e um jurados que se sortearão dentre os alistados, sete dos quais constituirão o conselho de sentença em cada sessão de julgamento.

Art. 434. O serviço do júri será obrigatório. O alistamento compreenderá os cidadãos maiores de 21 (vinte e um) anos, isentos os maiores de 60 (sessenta). 
Art. 435. A recusa ao serviço do júri, motivada por convicção religiosa, filosófica ou política, importará a perda dos direitos políticos (Constituição, art. $119, b)$.

Art. 436. Os jurados serão escolhidos dentre cidadãos de notória idoneidade.

Parágrafo único. São isentos do serviço do júri:

I - o Presidente da República e os ministros de Estado;

II - os governadores ou interventores de Estados ou Territórios, o prefeito do Distrito Federal e seus respectivos secretários;

III - os membros do Parlamento Nacional, do Conselho de Economia Nacional, das Assembléias Legislativas dos Estados e das Câmaras Municipais, enquanto durarem suas reuniões;

IV - os prefeitos municipais;

V - os magistrados e órgãos do Ministério Público;

VI - os serventuários e funcionários da justiça;

VII - o chefe, demais autoridades e funcionários da Polícia e Segurança Pública;

VIII - os militares em serviço ativo;

IX - as mulheres que não exerçam função pública e provem que, em virtude de ocupações domésticas, o serviço do júri lhes é particularmente difícil;

$\mathrm{X}$ - por 1 (um) ano, mediante requerimento, os que tiverem efetivamente exercido a função de jurado, salvo nos lugares onde tal isenção possa redundar em prejuízo do serviço normal do júri;

$\mathrm{XI}$ - quando o requererem e o juiz reconhecer a necessidade da dispensa:

a) os médicos e os ministros de confissão religiosa;

b) os farmacêuticos e as parteiras.

Art. 437. O exercício efetivo da função de jurado constituirá serviço público relevante, estabelecerá presunção de idoneidade moral e assegurará prisão especial, em caso de crime comum, até o julgamento definitivo, bem como preferência, em igualdade de condições, nas concorrências públicas. 
Art. 438. Os jurados serão responsáveis criminalmente, nos mesmos termos em que o são os juízes de ofício, por concussão, corrupção ou prevaricação (Código Penal, arts. 316, 317, §§ $1^{\circ}$ e $2^{\circ}$, e 319 ).

Seção III

\section{Da organização do júri}

Art. 439. Anualmente, serão alistados pelo juiz-presidente do júri, sob sua responsabilidade e mediante escolha por conhecimento pessoal ou informação fidedigna, 300 (trezentos) a 500 (quinhentos) jurados no Distrito Federal e nas comarcas de mais de 100.000 (cem mil) habitantes, e 80 (oitenta) a 300 (trezentos) nas comarcas ou nos termos de menor população. O juiz poderá requisitar às autoridades locais, associações de classe, sindicatos profissionais e repartições públicas a indicação de cidadãos que reunam as condições legais.

Parágrafo único. A lista geral, publicada em novembro de cada ano, poderá ser alterada de ofício, ou em virtude de reclamação de qualquer do povo, até à publicação definitiva, na segunda quinzena de dezembro, com recurso, dentro de 20 (vinte) dias, para a superior instância, sem efeito suspensivo.

Art. 440. A lista geral dos jurados, com indicação das respectivas profissões, será publicada pela imprensa, onde houver, ou em editais afixados à porta do edifício do tribunal, lançando-se os nomes dos alistados, com indicação das residências, em cartões iguais, que, verificados com a presença do órgão do Ministério Público, ficarão guardados em urna fechada a chave sob a responsabilidade do juiz.

Art. 441. Nas comarcas ou nos termos onde for necessário, organizar-se-á lista de jurados suplentes, depositando-se as cédulas em urna especial.

\section{Seção IV}

\section{Do jnulgamento pelo júri}

Art. 442. No dia e à hora designados para reunião do júri, presente o órgão do Ministério Público, o presidente, depois de verificar se a urna contém as cédulas com os nomes dos vinte e um jurados sorteados, mandará que o escrivão Ihes proceda à chamada, declarando instalada a sessão, se comparecerem pelo menos quinze deles, ou, no caso contrário, convocando nova sessão para o dia útil imediato.

Art. 443. O jurado que, sem causa legítima, não comparecer, incorrerá na multa de cem mil-réis por dia de sessão realizada ou não realizada por falta de número legal até o término da sessão periódica. 
$\S 11^{\circ} \mathrm{O}$ jurado incorrerá em multa pelo simples fato do nãocomparecimento, independentemente de ato do presidente ou termo especial.

$\S 2$ ㅇ Somente serão aceitas as escusas apresentadas até o momento da chamada dos jurados e fundadas em motivo relevante, devidamente comprovado.

§ $3^{0}$ Incorrerá na multa de trezentos mil-réis o jurado que, tendo comparecido, se retirar antes de dispensado pelo presidente, observado 0 disposto no $\S 1^{\circ}$, parte final.

$\S 4^{\circ}$ Sob pena de responsabilidade, o presidente só relevará as multas em que incorrerem os jurados faltosos, se estes, dentro de 48 (quarenta e oito) horas, após o encerramento da sessão periódica, oferecerem prova de justificado impedimento.

Art. 444. As multas em que incorrerem os jurados serão cobradas pela Fazenda Pública, a cujo representante o juiz remeterá no prazo de 10 (dez) dias, após o encerramento da sessão periódica, com a relação dos jurados multados, as certidões das atas de que constar o fato, as quais, por ele rubricadas, valerão como título de dívida líquida e certa.

Parágrafo único. Sem prejuízo da cobrança imediata das multas, será remetida cópia das certidões à autoridade fiscal competente para a inscrição da dívida.

Art. 445. Verificando não estar completo o número de 21 (vinte e um) jurados, embora haja o mínimo legal para a instalação da sessão, o juiz procederá ao sorteio dos suplentes necessários, repetindo-se o sorteio até perfazer-se aquele número.

$\S 1^{\circ}$ Nos Estados e Territórios, serão escolhidos como suplentes, dentre os sorteados, os jurados residentes na cidade ou vila ou até a distância de 20 (vinte) quilômetros.

$\S 2^{\circ}$ Os nomes dos suplentes serão consignados na ata, seguindo-se a respectiva notificação para comparecimento.

$\S 3^{\circ}$ Os jurados ou suplentes que não comparecerem ou forem dispensados de servir na sessão periódica serão, desde logo, havidos como sorteados para a seguinte.

$\S 4^{\circ}$ Sorteados os suplentes, os jurados substituídos não mais serão admitidos a funcionar durante a sessão periódica.

Art. 446. Aos suplentes são aplicáveis os dispositivos referentes às dispensas, faltas, escusas e multas. 
Art. 447. Aberta a sessão, o presidente do tribunal, depois de resolver sobre as escusas, na forma dos artigos anteriores, abrirá a urna, dela retirará todas as cédulas, verificando uma a uma, e, em seguida, colocará na urna as relativas aos jurados presentes e, fechando-a, anunciará qual o processo que será submetido a julgamento e ordenará ao porteiro que apregoe as partes e as testemunhas.

Parágrafo único. A intervenção do assistente no plenário de julgamento será requerida com antecedência, pelo menos, de 3 (três) dias, salvo se já tiver sido admitido anteriormente.

Art. 448. Se, por motivo de força maior, não comparecer o órgão do Ministério Público, o presidente adiará o julgamento para o primeiro dia desimpedido, da mesma sessão periódica. Continuando o órgão do Ministério Público impossibilitado de comparecer, funcionará o substituto legal, se houver, ou promotor ad hoc.

Parágrafo único. Se o órgão do Ministério Público deixar de comparecer sem escusa legítima, será igualmente adiado o julgamento para o primeiro dia desimpedido, nomeando-se, porém, desde logo, promotor ad hoc, caso não haja substituto legal, comunicado o fato ao procurador-geral.

Art. 449. Apregoado o réu, e comparecendo, perguntar-lhe-á o juiz o nome, a idade e se tem advogado, nomeando-lhe curador, se for menor e não o tiver, e defensor, se maior. Em tal hipótese, o julgamento será adiado para o primeiro dia desimpedido.

Parágrafo único. O julgamento será adiado, somente uma vez, devendo o réu ser julgado, quando chamado pela segunda vez. Neste caso a defesa será feita por quem o juiz tiver nomeado, ressalvado ao réu o direito de ser defendido por advogado de sua escolha, desde que se ache presente.

Art. 450. A falta, sem escusa legítima, do defensor do réu ou do curador, se um ou outro for advogado ou solicitador, será imediatamente comunicada ao Conselho da Ordem dos Advogados, nomeando o presidente do tribunal, em substituição, outro defensor, ou curador, observado o disposto no artigo anterior.

Art. 451. Não comparecendo o réu ou o acusador particular, com justa causa, o julgamento será adiado para a seguinte sessão periódica, se não puder realizar-se na que estiver em curso.

§ 1ํ Se se tratar de crime afiançável, e o não-comparecimento do réu ocorrer sem motivo legítimo, far-se-á o julgamento à sua revelia.

$\S 2^{\circ}$ O julgamento não será adiado pelo não-comparecimento do advogado do assistente. 
Art. 452. Se o acusador particular deixar de comparecer, sem escusa legítima, a acusação será devolvida ao Ministério Público, não se adiando por aquele motivo o julgamento.

Art. 453. A testemunha que, sem justa causa, deixar de comparecer, incorrerá na multa de cinco a cinqüenta centavos, aplicada pelo presidente, sem prejuízo do processo penal, por desobediência, e da observância do preceito do art. 218. (Redação dada pela Lei $n^{\circ}$ 6.416, de 24.5.1977)

Parágrafo único. Aplica-se às testemunhas, enquanto a serviço do júri, o disposto no art. 430.

Art. 454. Antes de constituído o conselho de sentença, as testemunhas, separadas as de acusação das de defesa, serão recolhidas a lugar de onde não possam ouvir os debates, nem as respostas umas das outras.

Art. 455. A falta de qualquer testemunha não será motivo para o adiamento, salvo se uma das partes tiver requerido sua intimação, declarando não prescindir do depoimento e indicando seu paradeiro com a antecedência necessária para a intimação. Proceder-se-á, entretanto, ao julgamento, se a testemunha não tiver sido encontrada no local indicado.

$\S 1^{\circ}$ Se, intimada, a testemunha não comparecer, o juiz suspenderá os trabalhos e mandará trazê-la pelo oficial de justiça ou adiará o julgamento para o primeiro dia útil desimpedido, ordenando a sua condução ou requisitando à autoridade policial a sua apresentação.

$\S 2^{\circ}$ Não conseguida, ainda assim, a presença da testemunha no dia designado, proceder-se-á ao julgamento.

Art. 456. O porteiro do tribunal, ou na falta deste, o oficial de justiça, certificará haver apregoado as partes e as testemunhas.

Art. 457. Verificado publicamente pelo juiz que se encontram na urna as cédulas relativas aos jurados presentes, será feito o sorteio de 7 (sete) para a formação do conselho de sentença.

rt. 458. Antes do sorteio do conselho de sentença, o juiz advertirá os jurados dos impedimentos constantes do art. 462, bem como das incompatibilidades legais por suspeição, em razão de parentesco com 0 juiz, com o promotor, com o advogado, com o réu ou com a vítima, na forma do disposto neste Código sobre os impedimentos ou a suspeição dos juízes togados.

§ 1ํ Na mesma ocasião, o juiz advertirá os jurados de que, uma vez sorteados, não poderão comunicar-se com outrem, nem manifestar sua opinião sobre o processo, sob pena de exclusão do conselho e multa, de duzentos a quinhentos mil-réis. 
$\S 2$ ㅇ Dos impedidos entre si por parentesco servirá o que houver sido sorteado em primeiro lugar.

Art. 459. Os jurados excluídos por impedimento ou suspeição serão computados para a constituição do número legal.

$\S 1^{\circ}$ Se, em conseqüência das suspeições ou das recusas, não houver número para a formação do conselho, o julgamento será adiado para o primeiro dia desimpedido.

$\S 2^{\circ}$ À medida que as cédulas forem tiradas da urna, o juiz as lerá, e a defesa e, depois dela, a acusação poderão recusar os jurados sorteados, até três cada uma, sem dar os motivos da recusa.

Art. 460. A suspeição argüida contra o presidente do tribunal, o órgão do Ministério Público, os jurados ou qualquer funcionário, quando não reconhecida, não suspenderá o julgamento, devendo, entretanto, constar da ata a argüição.

Art. 461. Se os réus forem dois ou mais, poderão incumbir das recusas um só defensor; não convindo nisto e se não coincidirem as recusas, dar-se-á a separação dos julgamentos, prosseguindo-se somente no do réu que houver aceito o jurado, salvo se este, recusado por um réu e aceito por outro, for também recusado pela acusação.

Parágrafo único. O réu, que pela recusa do jurado tiver dado causa à separação, será julgado no primeiro dia desimpedido.

Art. 462. São impedidos de servir no mesmo conselho marido e mulher, ascendentes e descendentes, sogro e genro ou nora, irmãos, cunhados, durante o cunhadio, tio e sobrinho, padrasto ou madrasta e enteado.

Art. 463. O mesmo conselho poderá conhecer de mais de um processo na mesma sessão de julgamento, se as partes o aceitarem; mas prestará cada vez novo compromisso.

Art. 464. Formado o conselho, o juiz, levantando-se, e com ele todos os presentes, fará aos jurados a seguinte exortação:

Em nome da lei, concito-vos a examinar com imparcialidade esta causa e a proferir a vossa decisão, de acordo com a vossa consciência e os ditames da justiça.

Os jurados, nominalmente chamados pelo juiz, responderão:

Assim o prometo.

Art. 465. Em seguida, o presidente interrogará o réu pela forma estabelecida no Livro I, Título VII, Capítulo III, no que for aplicável. 
Art. 466. Feito e assinado o interrogatório, o presidente, sem manifestar sua opinião sobre o mérito da acusação ou da defesa, fará o relatório do processo e exporá o fato, as provas e as conclusões das partes. (Redação dada pela Lei $n^{\circ} 263$, de 23.2.1948)

§1ำ Depois do relatório, o escrivão lerá, mediante ordem do presidente, as peças do processo, cuja leitura for requerida pelas partes ou por qualquer jurado. (Parágrafo acrescentado pela Lei $n^{\circ} 263$, de 23.2.1948)

§ 2 Onde for possível, o presidente mandará distribuir aos jurados cópias datilografadas ou impressas, da pronúncia, do libelo e da contrariedade, além de outras peças que considerar úteis para o julgamento da causa. (Parágrafo único renumerado pela Lei $n^{\circ} 263$, de 23.2.1948)

Art. 467. Terminado o relatório, o juiz, o acusador, o assistente e o advogado do réu e, por fim, os jurados que o quiserem, inquirirão sucessivamente as testemunhas de acusação.

Art. 468. Ouvidas as testemunhas de acusação, o juiz, o advogado do réu, o acusador particular, o promotor, o assistente e os jurados que o quiserem, inquirirão sucessivamente as testemunhas de defesa.

Art. 469. Os depoimentos das testemunhas de acusação e de defesa serão reduzidos a escrito, em resumo, assinado o termo pela testemunha, pelo juiz e pelas partes.

Art. 470. Quando duas ou mais testemunhas divergirem sobre pontos essenciais da causa, proceder-se-á de acordo com o disposto no art. 229, parágrafo único.

Art. 471. Terminada a inquirição das testemunhas o promotor lerá o libelo e os dispositivos da lei penal em que o réu se achar incurso, e produzirá a acusação.

$\S 1^{\circ} \mathrm{O}$ assistente falará depois do promotor.

$\S 2^{\circ}$ Sendo o processo promovido pela parte ofendida, o promotor falará depois do acusador particular, tanto na acusação como na réplica.

Art. 472. Finda a acusação, o defensor terá a palavra para defesa.

Art. 473. O acusador poderá replicar e a defesa treplicar, sendo admitida a reinquirição de qualquer das testemunhas já ouvidas em plenário.

Art. 474. O tempo destinado à acusação e à defesa será de 2 (duas) horas para cada um, e de meia hora a réplica e 
outro tanto para a tréplica. (Redação dada pela Lei $n^{\circ}$ 5.941, de 22.11.1973)

§ 1ํ Havendo mais de um acusador ou mais de um defensor, combinarão entre si a distribuição do tempo, que, na falta de entendimento, será marcado pelo juiz, por forma que não sejam excedidos os prazos fixados neste artigo. (Redação dada pela Lei $n^{\circ}$ 5.941, de 22.11.1973)

§ 2 Havendo mais de um réu, o tempo para a acusação e para a defesa será, em relação a todos, acrescido de 1 (uma) hora e elevado ao dobro o da réplica e da tréplica, observado o disposto no parágrafo anterior. (Redação dada pela Lei $n^{\circ}$ 5.941, de 22.11.1973)

Art. 475. Durante o julgamento não será permitida a produção ou leitura de documento que não tiver sido comunicado à parte contrária, com antecedência, pelo menos, de 3 (três) dias, compreendida nessa proibição a leitura de jornais ou qualquer escrito, cujo conteúdo versar sobre matéria de fato constante do processo.

Art. 476. Aos jurados, quando se recolherem à sala secreta, serão entregues os autos do processo, bem como, se o pedirem, os instrumentos do crime, devendo o juiz estar presente para evitar a influência de uns sobre os outros.

Parágrafo único. Os jurados poderão também, a qualquer momento, e por intermédio do juiz, pedir ao orador que indique a folha dos autos onde se encontra a peça por ele lida ou citada.

Art. 477. Se a verificação de qualquer fato, reconhecida essencial para a decisão da causa, não puder ser realizada imediatamente, o juiz dissolverá o conselho, formulando com as partes, desde logo, os quesitos para as diligências necessárias.

Art. 478. Concluídos os debates, o juiz indagará dos jurados se estão habilitados a julgar ou se precisam de mais esclarecimentos.

Parágrafo único. Se qualquer dos jurados necessitar de novos esclarecimentos sobre questão de fato, o juiz os dará, ou mandará que o escrivão os dê, à vista dos autos.

Art. 479. Em seguida, lendo os quesitos, e explicando a significação legal de cada um, o juiz indagará das partes se têm requerimento ou reclamação que fazer, devendo constar da ata qualquer requerimento ou reclamação não atendida.

Art. 480. Lidos os quesitos, o juiz anunciará que se vai proceder ao julgamento, fará retirar o réu e convidará os circunstantes a que deixem a sala. 
Art. 481. Fechadas as portas, presentes o escrivão e dois oficiais de justiça, bem como os acusadores e os defensores, que se conservarão nos seus lugares, sem intervir nas votações, o conselho, sob a presidência do juiz, passará a votar os quesitos que lhe forem propostos.

Parágrafo único. Onde for possível, a votação será feita em sala especial.

Art. 482. Antes de dar o seu voto, o jurado poderá consultar os autos, ou examinar qualquer outro elemento material de prova existente em juízo.

Art. 483. O juiz não permitirá que os acusadores ou os defensores perturbem a livre manifestação do conselho, e fará retirar da sala aquele que se portar inconvenientemente, impondo-lhe multa, de duzentos a quinhentos mil-réis.

Art. 484. Os quesitos serão formulados com observância das seguintes regras:

I - o primeiro versará sobre o fato principal, de conformidade com o libelo;

II - se entender que alguma circunstância, exposta no libelo, não tem conexão essencial com o fato ou é dele separável, de maneira que este possa existir ou subsistir sem ela, o juiz desdobrará o quesito em tantos quantos forem necessários;

III - se o réu apresentar, na sua defesa, ou alegar, nos debates, qualquer fato ou circunstância que por lei isente de pena ou exclua o crime, ou o desclassifique, o juiz formulará os quesitos correspondentes, imediatamente depois dos relativos ao fato principal, inclusive os relativos ao excesso doloso ou culposo quando reconhecida qualquer excludente de ilicitude; (Redação dada pela Lei $n^{\circ}$ 9.113, de 16.10.1995)

IV - se for alegada a existência de causa que determine aumento de pena em quantidade fixa ou dentro de determinados limites, ou de causa que determine ou faculte diminuição de pena, nas mesmas condições, o juiz formulará os quesitos correspondentes a cada uma das causas alegadas;

$\mathrm{V}$ - se forem um ou mais réus, o juiz formulará tantas séries de quesitos quantos forem eles. Também serão formuladas séries distintas, quando diversos os pontos de acusação;

$\mathrm{VI}$ - quando o juiz tiver que fazer diferentes quesitos, sempre os formulará em proposições simples e bem distintas, de maneira que cada um deles possa ser respondido com suficiente clareza.

Parágrafo único. Serão formulados quesitos relativamente às circunstâncias agravantes e atenuantes, previstas nos 
arts. 44, 45 e 48 do Código Penal, observado o seguinte: (Redação dada pela Lei $n^{\circ} 263$, de 23.2.1948)

I - para cada circunstância agravante, articulada no libelo, o juiz formulará um quesito;

II - se resultar dos debates o conhecimento da existência de alguma circunstância agravante, não articulada no libelo, o juiz, a requerimento do acusador, formulará o quesito a ela relativo;

III - o juiz formulará, sempre, um quesito sobre a existência de circunstâncias atenuantes, ou alegadas;

IV - se o júri afirmar a existência de circunstâncias atenuantes, o juiz o questionará a respeito das que lhe parecerem aplicáveis ao caso, fazendo escrever os quesitos respondidos afirmativamente, com as respectivas respostas.

Art. 485. Antes de proceder-se à votação de cada quesito, o juiz mandará distribuir pelos jurados pequenas cédulas, feitas de papel opaco e facilmente dobráveis, contendo umas a palavra sim e outras a palavra não, a fim de, secretamente, serem recolhidos os votos.

Art. 486. Distribuídas as cédulas, o juiz lerá o quesito que deva ser respondido e um oficial de justiça recolherá as cédulas com os votos dos jurados, e outro, as cédulas não utilizadas. Cada um dos oficiais apresentará, para esse fim, aos jurados, uma urna ou outro receptáculo que assegure o sigilo da votação.

Art. 487. Após a votação de cada quesito, o presidente, verificados os votos e as cédulas não utilizadas, mandará que o escrivão escreva 0 resultado em termo especial e que sejam declarados o número de votos afirmativos e o de negativos.

Art. 488. As decisões do júri serão tomadas por maioria de votos.

Art. 489. Se a resposta a qualquer dos quesitos estiver em contradição com outra ou outras já proferidas, o juiz, explicando aos jurados em que consiste a contradição, submeterá novamente à votação os quesitos a que se referirem tais respostas.

Art. 490. Se, pela resposta dada a qualquer dos quesitos, o juiz verificar que ficam prejudicados os seguintes, assim o declarará, dando por finda a votação.

Art. 491. Finda a votação, será o termo a que se refere o art. 487 assinado pelo juiz e jurados. 
Art. 492. Em seguida, o juiz lavrará a sentença, com observância do seguinte: (Redação dada pela Lei $n^{\circ} 263$, de 23.2.1948)

I - no caso de condenação, terá em vista as circunstâncias agravantes ou atenuantes reconhecidas pelo júri, $e$ atenderá, quanto ao mais, ao disposto nos no-s. II a VI do art. 387; (Redação dada pela Lei $n^{\circ} 263$, de 23.2.1948)

II - no caso de absolvição: (Redação dada pela Lei $n^{\circ}$ 263, de 23.2.1948)

a) mandará pôr o réu em liberdade, se afiançável o crime, ou desde que tenha ocorrido a hipótese prevista no art. 316, ainda que inafiançável;

b) ordenará a cessação das interdições de direitos que tiverem sido provisoriamente impostas;

c) aplicará medida de segurança, se cabível.

$\S 1^{\circ}$ Se, pela resposta a quesito formulado aos jurados, for reconhecida a existência de causa que faculte diminuição da pena, em quantidade fixa ou dentro de determinados limites, ao juiz ficará reservado o uso dessa faculdade.

$\S 2^{\circ}$ Se for desclassificada a infração para outra atribuída à competência do juiz singular, ao presidente do tribunal caberá proferir em seguida a sentença.

Art. 493. A sentença será fundamentada, salvo quanto às conclusões que resultarem das respostas aos quesitos, e lida pelo juiz, de público, antes de encerrada a sessão do julgamento.

Art. 494. De cada sessão de julgamento o escrivão lavrará ata, assinada pelo juiz e pelo órgão do Ministério Público.

Art. 495. A ata descreverá fielmente todas as ocorrências e mencionará especialmente:

I - a data e a hora da instalação dos trabalhos;

II - o magistrado que a presidiu e os jurados presentes;

III - os jurados que deixarem de comparecer, com escusa legítima ou sem ela, e os ofícios e requerimentos a respeito apresentados e arquivados;

IV - os jurados dispensados e as multas impostas; 
V - o sorteio dos suplentes;

VI - o adiamento da sessão, se houver ocorrido, com a declaração do motivo;

VII - a abertura da sessão e a presença do órgão do Ministério Público;

VIII - o pregão das partes e das testemunhas, o seu comparecimento, ou não, e as penas impostas às que faltaram;

IX - as testemunhas dispensadas de depor;

X - o recolhimento das testemunhas a lugar de onde não pudessem ouvir os debates, nem as respostas umas das outras;

XI - a verificação das cédulas pelo juiz;

XII - a formação do conselho de sentença, com indicação dos nomes dos jurados sorteados e das recusas feitas pelas partes;

XIII - o compromisso, simplesmente com referência ao termo;

XIV - o interrogatório, também com a simples referência ao termo;

$\mathrm{XV}$ - o relatório e os debates orais;

$\mathrm{XVI}$ - os incidentes;

XVII - a divisão da causa;

XVIII - a publicação da sentença, na presença do réu, a portas abertas.

Art. 496. A falta da ata sujeita o responsável a multa, de duzentos a quinhentos mil-réis, além da responsabilidade criminal em que incorrer.

\section{Seção V}

\section{Das atribuições do Presidente do Tribunal do Júri}

Art. 497. São atribuições do presidente do Tribunal do Júri, além de outras expressamente conferidas neste Código:

I - regular a polícia das sessões e mandar prender os desobedientes;

II - requisitar o auxílio da força pública, que ficará sob sua exclusiva autoridade;

III - regular os debates; 
IV - resolver as questões incidentes, que não dependam da decisão do júri;

$\mathrm{V}$ - nomear defensor ao réu, quando o considerar indefeso, podendo, neste caso, dissolver o conselho, marcado novo dia para o julgamento e nomeado outro defensor;

VI - mandar retirar da sala o réu que, com injúrias ou ameaças, dificultar o livre curso do julgamento, prosseguindo-se independentemente de sua presença;

VII - suspender a sessão pelo tempo indispensável à execução de diligências requeridas ou julgadas necessárias, mantida a incomunicabilidade dos jurados;

VIII - interromper a sessão por tempo razoável, para repouso ou refeição dos jurados;

IX - decidir de ofício, ouvidos o Ministério Público e a defesa, ou a requerimento de qualquer das partes, a preliminar da extinção da punibilidade;

$\mathrm{X}$ - resolver as questões de direito que se apresentarem no decurso do julgamento;

$\mathrm{XI}$ - ordenar de oficio, ou a requerimento das partes ou de qualquer jurado, as diligências destinadas a sanar qualquer nulidade, ou a suprir falta que prejudique o esclarecimento da verdade.

CAPÍTULO III

\section{DO PROCESSO E DO JULGAMENTO DOS}

\section{CRIMES DA COMPETÊNCIA DO JUIZ SINGULAR}

Art. 498. No processo dos crimes da competência do juiz singular, observar-se-á, na instrução, o disposto no Capítulo I deste Título.

Art. 499. Terminada a inquirição das testemunhas, as partes primeiramente o Ministério Público ou o querelante, dentro de 24 (vinte e quatro) horas, e depois, sem interrupção, dentro de igual prazo, o réu ou réus - poderão requerer as diligências, cuja necessidade ou conveniência se origine de circunstâncias ou de fatos apurados na instrução, subindo logo os autos conclusos, para o juiz tomar conhecimento do que tiver sido requerido pelas partes.

Art. 500. Esgotados aqueles prazos, sem requerimento de qualquer das partes, ou concluídas as diligências requeridas e ordenadas, será aberta vista dos autos, para alegações, sucessivamente, por 3 (três) dias: 


\title{
DEMOCRACIA E TRIBUNAL DO JÚRI NO BRASIL: ANÁLISE DE ALGUNS TEXTOS DOUTRINÁRIO-CRIMINAIS (1987-1995)
}

\author{
Ana Lúcia Pastore Schritzmeyer \\ Doutoranda do Programa de Pós-Graduação em Antropologia Social \\ FFLCH-USP \\ Orientadora: Prof ${ }^{t}$ Dr $^{a}$ Paula Montero
}

Disciplina: FLS-898

"Democracia, Política e Sociedade: Teorias X Realidades"

Professor: Lúcio Kowarick 


\section{Considerações Iniciais: Intenções}

Este trabalho pretende, antes de tudo, propiciar um exercício de reflexão interdisciplinar entre Ciência Política e Direito, servindo-se da primeira para situar algumas das principais questões referentes ao debate teórico contemporâneo em torno do conceito de democracia e, valendo-se do segundo para problematizar tal debate, situando-o na produção doutrinário-criminal sobre o caráter democrático ou antidemocrático do tribunal do júri existente no Brasil.

Trabalhar-se-á com dois rec ursos básicos: parte da bibliografia estudada para a disciplina "Democracia, Política e Sociedade: Teorias X Realidades" e dezoito textos doutrinário -criminais sobre o tribunal do júri, recentemente publicados (1987/1995) pela Revista dos Tribunais - RT, uma das mais importantes fontes de consulta e formação de jurisprudência e doutrina jurídica brasileiras.

\section{Debate Teórico Contemporâneo em torno do Conceito de Democracia}

\section{II.1. Algumas Questões}

Ao longo do primeiro semestre, levantamos, delimitamos e discutimos algumas questões-chave à respeito de dilemas contemporâneos em torno do conceito de democracia. Enumerá-las implica correr o risco de selecionar, articular e simplificar o que o interesse e a memória retiveram; risco todavia necessário para iniciar uma reflexão.

Seis, talvez, tenham sido as questões-chave suscitadas pelos textos que estudamos e que neles também perseguimos:

1. $^{\text {a }) ~ R e s t r i n g e-s e ~ a ~ d e m o c r a c i a ~ a ~ r e g r a s ~ d e ~ p r o c e d i m e n t o, ~ s e n d o ~ s o m e n t e ~ u m a ~ f o r m a ~ d e ~}$ defesa da sociedade civil contra a tirania de uma minoria, ou será também uma forma de governo que produz a chamada cidadania ativa, ou seja, uma possibilidade de aumento da participação da sociedade civil em múltiplos espaços de tomada de decisão, tanto internos quanto externos à esfera política propriamente dita (escolas, hospitais, etc)?

2. $\left.{ }^{a}\right)$ Tal alargamento da participação da sociedade civil é desejável para a melhoria do sistema político, pois significa uma democracia emancipatória, da qual podem decorrer novas formas de controle de decisões políticas, de seus resultados e criação de novos valores, como tolerância, reciprocidade, alteridade, aceitação das diferenças? Ou tal alargamento é nefasto, uma vez que pode representar justamente descontrole de decisões políticas, de resultados e de valores?

3. ${ }^{\mathbf{a}}$ ) Quais questões se colocam para a democracia quando a imensa maioria da população efetivamente não participa de processos decisórios referentes a questões públicas e quais as possibilidades de participação numa sociedade de massas, em que há "falas competentes" para cada assunto tratado?

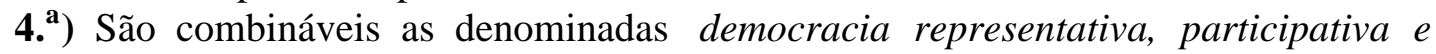
direta?

5. $\left.{ }^{a}\right)$ Como a chamada democracia direta, para além de plebiscitos e eleições, pode ser de fato exercida e quais os alcances e limites da democracia representativa? 


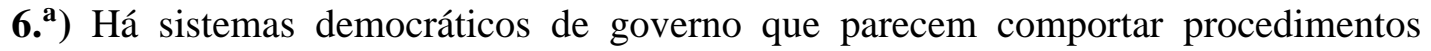
políticos não democráticos, bem como há sistemas não democráticos que parecem comportar procedimentos democráticos. Enquanto procedimento político, a democracia é eficiente em si mesma ou necessita de um sistema de governo também democrático que a suporte?

\section{II.2. Algumas Respostas ${ }^{1}$}

\section{II.2.a) Elitismo Democrático}

- Schumpeter foi o primeiro teórico que nos suscitou ao menos três das questões mencionadas. Embora fosse um economista e não um cientista político, criou um marco na teoria política da democracia.

Entendendo-a como método político, como meio e não como fim, preocupado, portanto, com suas formas de funcionamento e não com seus resultados, ele apontou nesse método a vigência de consensos resultantes não da vontade da maioria, mas construídos em torno de facções reciprocamente tolerantes umas com as outras, ou seja, minorias cujas convicções são geralmente autoritárias e que tentam alcançar o poder competindo livremente pelo voto popular. Considera democracia, portanto, como competição livre pelo voto popular, mas disto não conclui que governo democrático seja governo do povo.

Não vê, aliás, como o povo possa se envolver diretamente em todos os assuntos da esfera pública, uma vez que está, pelo contrário, alheio à maior parte deles. Neste sentido, defende a necessidade de uma certa independência das elites em relação ao eleitorado, visto que a primeira pode e deve se voltar para "macroproblemas" coletivos, enquanto o eleitorado está muito mais às voltas com seus "microproblemas" pessoais.

A dita vontade popular, segundo Schumpeter, é criada por lideranças, grupos de interesse, partidos, tendo estes papel mais primordial na democracia do que o povo, pois enquanto as lideranças decidem questões de conteúdo, o povo apenas escolhe quem as decidirá. Inaugura-se, com estas idéias, uma das mais importantes alas do pensamento político contemporâneo, privilegiando a análise do papel das lideranças em detrimento de debates sobre a participação popular, o que era central para os teóricos clássicos da democracia.

Juntamente com outros pensadores, como Robert Dahl e Giovanni Sartori, Schumpeter pode ser considerado um teórico do elitismo democrático, descartando a idéia de que a democracia contemporânea possa ser emancipatória ou participativa no sentido de envolvimento popular em questões globais, o qual inclusive vê como potencialmente desastroso para o bom funcionamento do método democrático.

Enquanto sistema de governo, Schumpeter aponta a democracia como ineficiente, vislumbrando possibilidade de êxito somente se as classes política e burocrática forem de boa qualidade e se, apesar da existência de facções, houver

\footnotetext{
1 Os vários autores cujas idéias serão pontuadas e os respectivos textos nos quais elas se encontram desenvolvidas estão mencionados no item V.1 da Bibliografia, de modo que não os citaremos no corpo do texto.
} 
aceitação da legitimidade da facção governante pelas demais (tolerância entre facções). Com isto, está introduzida a idéia de que a competição política é fundamental na democracia, por um lado porque quanto mais intensa a competição, mais eficaz poderá ser o processo eleitoral enquanto forma de controle das elites e mais as boas qualidades destas poderão se desenvolver, por outro lado porque a livre competição pode aumentar as chances de existência de liberdade individual, o que muito se compatibiliza com o capitalismo.

Apesar de muito próximas às idéias de Schumpeter, as de Giovanni Sartori não podem ser classificadas como essencialmente realistas, pois enquanto para o primeiro a democracia "é o que é", para Sartori ela também é um "dever ser", um projeto político de intervenção guiado por valores, do que decorre a necessidade, segundo ele, de se distinguir fatos, valores e tensões existentes entre ambos.

São três os modelos de democracia analisados por Sartori: o eleitoral, no qual aposta; o de referendo e o participativo.

Fazendo uma abordagem tipicamente representativa e se remetendo a pesquisas que revelam uma apatia generalizada e crescente entre os eleitores, afirma que estes elegem representantes e não políticas públicas, as quais desconhecem e não acompanham. Contribui, assim, num certo sentido, com a ótica do realismo político schumpeteriano, porém não deixando de discutir o idealismo democrático, pois se propõe a analisar a opinião pública, apostando na formação de públicos interessados e autônomos. Neste sentido, ressalta a importância de microdemocracias participativas (sindicatos, associações, etc) embora conclua pela inviabilidade da macroparticipação popular. Considera, inclusive, catastrófico o participacionismo em larga escala para a democracia representativa, pois em nome da atribuição de autonomia ao povo, acha que se pode chegar a decisões politicamente incompetentes.

O "dever ser" ou projeto democrático apontado por Sartori aposta, portanto, na opinião pública, na abertura de possibilidades para o exercício democrático e de controle dos representantes por públicos interessados e especializados. À pergunta "quem decide" Sartori apresenta, para além da resposta "elites", a possibilidade "públicos". Inexistem, para ele, uma classe dominante, como aponta o marxismo clássico, ou uma elite do poder, como afirma Wright Mills. O que vislumbra, combinado com a idéia de ética da responsabilidade, são múltiplos centros decisórios, formados por múltiplos públicos que, embora conflituosos, podem ser minimamente gerenciados. Esta abordagem poliárquica da divisão do poder revela a influência de Dahl sobre o pensamento de Sartori.

Para Robert Dahl, um democrata realista influenciado pela ótica americana, poliarquia é a moderna tradução de democracia representativa no contexto das sociedades de massa, podendo-se falar também em democracias policêntricas. Aponta a poliarquia como um conjunto de condições para que a democracia funcione em tais sociedades, conjunto este caracterizado por coalizões de muitas minorias fracionadas, formando maiorias temporariamente governantes. Esta abordagem, segundo o autor, torna mais claro o debate em torno do conceito de democracia, retirando de cena questões sobre ideais democráticos e enfatizando a importância de análises comparativas entre instituições contemporâneas. 
Segundo Dahl, entre 1776 e 1930, houve um crescimento generalizado de poliarquias no mundo, ao que se seguiu uma onda de "epidemias autoritárias", voltando as poliarquias a ganhar força a partir dos anos 70. Analisa as atuais como poliarquias mais amplas que as anteriores, porém mais fracas, pois embora atinjam um maior número de cidadãos, estes estão menos mobilizados e são menos mobilizáveis.

As questões da representação e da participação são centrais para Dahl e ele as aborda tendo como pano de fundo o pluralismo social e organizativo da típica sociedade civil contemporânea americana. Nesta, acredita existir uma estreita relação entre a expansão dos direitos individuais e o fortalecimento de poliarquias, pois, ao restringirem a participação dos cidadãos a espaços públicos, as poliarquias acabam por estimulá-los a atuarem em esferas privadas. Sem direitos individuais, ou seja, sem autonomia organizativa, Dahl não concebe a existência de poliarquias. A esta condição adiciona mais quatro:

a) ocorrência de eleições livres e justas: pouca coerção, competências submetidas a regras preestabelecidas; direito de eleger e ser eleito; autonomia associativa; liberdade de expressão e informações concorrentes que tendam a se aperfeiçoar;

b) controle civil da polícia e dos militares, com existência de milícias populares e elaboração de uma pedagogia civil para militares;

c) poderes civis democraticamente eleitos, ou seja, uma diversidade social organizada;

d) apesar do pluralismo de interesses, a existência de alguma homogeneidade cultural, pois quanto mais alta a produção de consensos, melhor a atuação poliárquica.

Numa linha realista, considera as poliarquias um fato, não afirmando, todavia, que constituam o que de mais desejável se possa garantir e consolidar. Encara como problemática a fraca e insuficiente participação da sociedade civil em questões da esfera pública, acrescentando que, paradoxalmente, tal possibilidade de participação nunca foi tão legalmente garantida e ampliada quanto o é nos dias atuais. Desde que contida constitucionalmente e de acordo com a lógica poliárquica, não vê com maus olhos a ampliação da participação popular. Poucos conceitos foram mais discutidos pela Ciência Política e causaram mais polêmica do que os de poliarquia e policentrismo.

Paul Hirst é outro exemplo de pensador que se dedicou a este debate, preocupando-se com o funcionamento do pluralismo e com seus mecanismos de controle ideológicos e não institucionalizados, os quais, segundo ele, ainda não tiveram suas complexidades devidamente analisadas.

Refletindo sobre a obra de Dahl, Hirst divide-a em dois momentos: o da idéias por ele elaboradas na década de 50, voltadas para a análise da inexistência de uma classe dominante estável, e o das idéias formuladas nos anos 70/80, relacionadas a reflexões sobre classes dominantes ou instituições resistentes à poliarquia. O próprio Dahl, de fato, revisou as bases de sua teoria, chegando a questionar se nos Estados Unidos, ao invés de um sistema poliárquico, haveria uma oligarquia competitiva. Reconheceu que, nesse país, decisões consideradas estratégicas são tomadas no âmbito 
estatal restrito, sem consulta ao parlamento, o que põe em xeque a capacidade da sociedade poliárquica de controlar e cobrar decisões do Estado.

Criticando a visão tradicionalista de bem comum enquanto meta universal e

monolítica, típica de pequenas comunidades homogêneas em que os conflitos são tidos como males a serem combatidos, Dahl propõe uma visão pluralista de bem comum como conjunto de práticas, instituições e processos desprovidos de conteúdo metafísico, ou seja, um conjunto de múltiplos bens. Realizar essa pluralidade de interesses exige, na sua opinião, uma justiça relativizada, com diferentes princípios a serem aplicados a diferentes bens sociais.

Dahl exclui as sociedades de pequena escala do horizonte de um futuro democrático, pois vê, em universos comunitários, o risco da prevalência de identidades unificadoras e, portanto, de uma democracia muito seletiva. Além desta conclusão preliminar, chega a algumas outras sobre condições necessárias para a ocorrência de sociedades democráticas avançadas:

— os cidadãos deverão ter igualdades políticas não como fim, mas como meio para alcançarem a justa distribuição de outras igualdades;

- a ordem econômica deverá se tornar instrumental ao ser humano e os Estados Nacionais deverão ganhar mais autonomia, apesar de assuntos importantes tenderem a ser resolvidos em arenas internacionais;

- vislumbra que o processo de democratização no interior de empresas privadas se viabilizará, desde que insuflado por um Estado garantidor de um "mercado socialista";

- teme que perdure o perigo da tutela dos intelectuais, especialmente de especialistas em políticas públicas, o que poderá comprometer a democracia, a longo prazo.

- aposta em "públicos atentos", formados por civis, que deverão controlar processos decisórios e combater tutelas, auxiliados pelo aumento da circulação de informações e pelo acesso facilitado à educação.

Dentre os leitores críticos de Dahl, há os que perguntam se a poliarquia é a única forma histórica possível de se chegar à democracia em sociedades de massa, sem contar o problema decorrente da própria dúvida sobre a existência de poliarquia ou oligarquia nos Estados Unidos. Mas as críticas mais contundentes referem-se a uma possível falta de respostas às questões de Schumpeter sobre a apatia popular e a conseqüente não participação dos cidadãos na vida pública.

\section{II.2.b) Democracia Participativa}

Macpherson, partindo justamente da consideração de que o modelo elitista de democracia carece de inspiração ética, pois baseado numa visão de mercado político concorrencial em que prevalece a apatia da maioria frente às questões públicas, problematiza as possibilidades de maior participação popular e de existência de uma ética emancipatória, propondo outro modelo que "oxigenaria" o elaborado por Schumpeter.

Pergunta-se como os governantes podem ser controlados além do voto tornando mais fluido e maleável o sistema. Como resposta, embora reconhecendo a inviabilidade 
de democracias diretas, aponta para democracias participativas. Sugere que questões aparentemente triviais, relativas a interesses privados, podem levar os envolvidos à esfera pública, como problemas ecológicos, urbanos e de gênero. Declaradamente, não vê com bons olhos a apatia da maioria, indicando a necessidade de uma cidadania ativa.

Enquanto para Schumpeter, apenas as elites sabem o que é racional e bem dimensionam como agir, para Macpherson, as pessoas, em geral, são racionais e sabem o que querem, havendo a possibilidade de que participem ativamente de processos decisórios. Acredita que na transparência desses processos, ou seja, na circulação clara e correta de informações sobre questões e negócios públicos reside um dos aspectos fundamentais da democracia.

Carlos Estevam Martins, nesta mesma linha de pensamento, citando John Denvey, lembra que modelos autocráticos, baseados na crença de que o saber necessário se encontra confinado numa elite capaz e controladora, são modelos típicos de regimes apenas nominalmente democráticos, nos quais houve um abastardamento do genuíno ideal democrático.

Remetendo-se a Schumpeter como figura central do movimento revisionista, Carlos Estevam reconhece que seu mérito reside na aceitação do fenômeno da liderança, o que foi desprezado pela teoria clássica, entretanto, aponta que ao não reconhecer a democracia como modo de vida, mas apenas como método de tomada de decisões, Schumpeter recorreu a um "expediente ilícito".

Uma das teses centrais de Carlos Estevam, em vários de seus artigos, é a de que o ideal genuinamente democrático só se torna operante a partir de um adequado sistema de partidos. Estes seriam, na sua opinião, a forma principal, senão a única verdadeiramente efetiva e capaz de mediar a idealidade democrática e a realidade concreta capitalista.

Considera que os revisionistas substituíram o ideal democrático genuíno por uma concepção abastardada de democracia porque, ao invés de pensarem no ajuste da sociedade capitalista às idéias de "liberdade" e de "felicidade públicas", propuseram o contrário, ou seja, o ajuste das idéias democráticas aos interesses capitalistas. O desenvolvimento do sistema de partidos, segundo Carlos Estevam, permite a superação tanto da chamada democracia burguesa quanto da proletária conciliar, propiciando uma democracia mais incorporativa. Não sugere, portanto, a possibilidade de participação total de todos em tudo, mas uma participação indireta, em que partidos fariam com que os fracos na sociedade pudessem ser fortes no Estado, de modo que se torna fundamental o papel da militância em contraposição ao do político profissional, burocrata do partido. Cumpre-nos, todavia, questionar como Carlos Estevam pensa a crise dos partidos políticos na intermediação entre um modelo teórico pluralista de democracia e uma realidade histórica social-democrata.

\section{II.2.c) Governo das Leis e Democracia Representativa}

Norberto Bobbio, deslocando todo este debate do plano do governo dos homens para o do governo das leis, desenvolve sua teoria da democracia tendo como 
tese central que o funcionamento de regimes democráticos depende de leis cujo fim seja a manutenção da ordem e do bem estar social e tenha como meio a coerção sem violência. Considera que um governo das leis tanto pode ser democrático quanto autoritário, sendo inclusive preferível uma autocracia a um governo dos homens. Isto não significa que ele prefira outras formas de exercício do poder e de participação política à forma democrática; esta é a melhor que se pode ter, em sua opinião, desde que concebida e executada num governo das leis.

Jurista kelseniano, filósofo hobbesiano, historiador de linha ítalo-germânica, Bobbio direciona sua ampla formação para as grandes questões contemporâneas do pensamento político. Toma as leis como condição sine qua non para a existência da sociedade civil e, assim como Kelsen, concebe o Estado de Direito como um pleonasmo, uma vez que Estado é Direito e vice-versa. È no domínio do racional-legal, no da legitimação por procedimentos que Bobbio situa o governo das leis, indicando a produção e a aplicação do Direito, através delas, como o arcabouço desse governo. Nos primeiros capítulos dO Futuro da Democracia, expõe, com clareza, a necessidade da existência de grandes princípios éticos a partir dos quais se estabeleçam procedimentos que, por sua vez, subsidiarão outras regras.

Nos pilares do Estado de Direito, Bobbio situa o monopólio da coerção e sua legitimação, vendo a sociedade moderna como uma força centrípeta, desagregadora, que tem no Direito sua contraposta força centrífuga. Outra de suas principais preocupações reside na reflexão sobre como resolver os choques entre a realidade e a autonomia das vontades individuais, para ele um dos valores centrais da democracia.

Considera que, no âmbito do poder político, a democratização deve ser limitada, pois aquilo que poderia ser alcançado já o foi (eleições periódicas, sufrágio universal, sistema político aberto, liberdade de associação), mas não crê que assim deva ocorrer no âmbito do poder social, uma vez que, na esfera das relações sociais, poderes burocráticos ainda podem ser substituídos por outros democráticos, como em escolas, hospitais, fábricas, etc. Acha, portanto, materialmente inexeqüível a democracia direta, considerando uma cidadania total tão perigosa quanto um estadismo total.

Aponta, assim, para a necessidade da existência e ampliação de uma democracia social e representativa, localizando o problema do voto não mais na discussão sobre quem vota, mas no debate sobre onde cada um vota: em fábricas? escolas? vilas?

Como outros realistas, analisa o afastamento do homem comum em relação à esfera política, atribuindo-o à crescente complexidade das questões políticas, ao acelerado processo de burocratização em todas as esferas da vida social e à sobrecarga de demandas direcionadas ao governo, do que resulta uma oposição entre interesses grupais de um lado e decisões públicas de outro.

\section{II.2.d) Cidadania Ativa , Pluralidade e Democracia Emancipatória}

Hannah Arendt está dentre os principais questionadores da democracia representativa. Apesar de sua postura normativa, ela aposta na possibilidade de uma vita activa no contexto das sociedades de massa. Esta vita, segundo ela, se compõe de 
três esferas de atividade: a do labor (em que se dá a auto-reprodução natural do Homem na sua relação consigo mesmo); a do trabalho (em que se dá a produção do mundo, a partir da relação do Homem com a Natureza para a transformação da segunda) e a da ação (em que se dá a condição humana da pluralidade, a partir das relações entre os Homens).

Num esforço de retomar a contraposição entre público e privado, desde o mundo grego até a atualidade, Hannah Arendt lança, no contexto das sociedades de massa, a questão de quem tem direito a participar da polis. E, ao introduzir este debate, trata a pluralidade e a alteridade como condições para o diálogo. O termo público, para Arendt, significa o próprio mundo, na medida em que se remete a algo comum a todos, porém diferente do lugar que a cada um cabe dentro dele. Mundo está sendo concebido não como Terra, mas como artefato humano, assim como o é próprio Homem.

Hannah Arendt é uma crítica do isolamento e da apatia, não os vendo como desejáveis, não aceitando o homem-animal, tal como ele parece se apresentar nas sociedades de massa. Aponta a necessidade da recuperação do homem virtuoso, político, participativo na esfera pública e vê a política como um exercício de "virtu", um fim e não um meio para a resolução de conflitos, considerando a participação um valor não instrumental, mas um valor em si.

Alain Touraine, num de seus mais recentes e densos livros, em estilo ensaístico, catártico e propositivo, também redefine a idéia de democracia. De um cenário em que se misturam globalização, passividade, amorfismo e apatia, cultura de mercado, múltiplas segregações e massificação, enfim, de um cenário ind efinido em que vários atores sociais estão em formação, Touraine propõe que pensemos na construção de uma cultura democrática, de uma dimensão que envolva o reconhecimento do outro e, mais que isto, o reconhecimento no outro e em nós mesmos das diferenças que comportamos, sem que, contudo, extrapolemos uma base de igualdade. Por cultura democrática está entendendo a dinâmica entre sujeitos, suas ações democráticas, o reconhecimento de diferenças e um "reencantamento do mundo". Diversidade e alteridade são os elementos-chave com os quais trabalha para chegar à definição de democracia como um critério emancipatório.

O eixo desse seu recente livro gira em torno do que estará impedindo e o que poderá levar à democracia emancipatória. Tem o arrojo de apontar pistas.

Touraine alerta-nos para o perigo de confundirmos democracia e economia de mercado. Pontua que o desenvolvimento econômico pode levar tanto à democracia quanto ao autoritarismo, embora acredite que o não desenvolvimento econômico possa levar muito mais ao primeiro que à segunda. Alerta-nos, também para o risco de reduzirmos a democracia a instituições jurídicas.

\section{Debate Doutrinário-Criminal Contemporâneo em torno do Tribunal do Júri no Brasil}

\section{III.1. Algumas Questões e Algumas Respostas}


Em muitos dos países em que existe o chamado Júri Popular, dentre os quais se encontra o Brasil, temos hoje debates acalorados sobre a manutenção ou a alteração dessa instituição do Poder Judiciário, seja no sentido de ampliar sua competência, de diminuí la, ou mesmo de extinguíla. Trata-se de uma discussão sobre critérios para a escolha de representantes do "povo", sobre a capacidade destes para julgar e decidir através do voto secreto, sobre a soberania de seus julgamentos e decisões, sobre as competências que devem ser atribuídas a leigos e a técnicos, enfim, trata-se de um debate sobre democracia.

\section{III.1.a) Favoráveis e Contrários ao Júri}

O Tribunal do Júri no Brasil tem "adeptos fervorosos e muitos detratores. Em verdade, mais detratores que prosélitos" (STOCO, fev/1991: 250). Todavia, as sucessivas Constituições da República, deixaram de inclúf lo no capítulo referente ao Poder Judiciário e também na parte relativa aos Estados, para enumerá-lo dentre os direitos e garantias fundamentais", ou seja, para conceituarem no "como uma das garantias essenciais do regime democrático"3. Portanto, mesmo os não simpatizantes do Júri reconhecem que, como se trata de uma garantia constitucional, ele é um órgão judiciário que "a Constituição considerou fundamental para o direito de liberdade do cidadão" 4 .

A Constituição Federal vigente (de 05/10/1988), inclui o júri no rol dos Direitos e Garantias Individuais, indicando, em seu art. $5^{\circ}$, XXXVIII, que a lei ordinária o organizará sendo assegurados: a) a plenitude de defesa, b) o sigilo das votações, c) a soberania dos veredictos e d) a competência para o julgamento dos crimes dolosos contra a vida, os quais são: tentativa ou consumação de homicídio doloso (simples ou qualificado); induzimento, instigação ou auxílio ao suicídio; infanticídio e aborto tentados ou consumados (Código Penal - CP - arts. 121, $\S 1^{\circ}$ e $2^{\circ} ; 122$, $\S$ único, e 123 a 127).

\section{III.1.b) Duas Grandes Questões}

A discussão sobre a validade e manutenção do júri no Direito brasileiro vem de longa data e duas são as principais questões que tem sido debatidas, das quais a maioria das outras decorrem:

$1^{\text {a })}$ por que apenas crimes dolosos contra a vida são de sua competência?

$2^{\mathrm{a}}$ ) quais as implicações relativas à participação de juízes leigos?

Uma das respostas à primeira questão, e que tem encontrado alguma ressonância na doutrina criminal, é favorável à interpretação ampliativa dos direitos e garantias individuais, o que, no caso do júri, implica dizer que a Constituição não só o

\footnotetext{
${ }^{2}$ Assim foi nas Constituições de 1891, 1946 e 1967, bem como na EC 1/69, não ocorrendo o mesmo na Constituição do Império e na de 1934, casos em que o júri foi tratado como um dos órgãos do poder Judiciário.

3 TRIGUEIRO, Oswaldo - Direito Constitucional Estadual, Rio de Janeiro: Forense, 1980: 214.

4 MARQUES, José Frederico - A Instituição do Júri, v.I/53. São Paulo: Saraiva, 1963
} 
institucionaliza como o garante, estabelecendo que ele existirá com, no mínimo, as características por ela enunciadas. Cabe, assim, à lei ordinária implementá-las, sem quaisquer limitações, podendo também ampliá-las, convocando o júri, por exemplo, para atuar em qualquer caso, "mesmo extrapenal" (RAMOS, jan/1994: 285).

Segundo alguns, seriam motivações principalmente econômicas as que limitam a competência do Tribunal do Júri no Brasil aos crimes dolosos contra a vida, pois estes, em relação aos demais delitos, ocorrem em menor número e, portanto, implicam um ônus administrável. ${ }^{5}$ Mesmo os mais favoráveis à ampliação da competência do júri, no entanto, fazem ressalvas à ampliação irrestrita, considerando incabível que todo e qualquer caso chegue até esse tribunal, como, por exemplo, os de "altíssima complexidade probatória", os de "enorme incidência" e os de "ínfimo valor" (idem:285-286).

Juristas contrários à ampliação, como Damásio de Jesus, membro do Conselho Nacional de Política Criminal e Penitenciária, afirmam que o perfil institucional do júri, definido na Constituição Federal, estabelece seus limites máximos e não mínimos, sendo vedado ao legislador ordinário propor outras hipóteses de julgamento popular. Mas é nos debates referentes à $2^{\mathrm{a}}$ questão que a resposta à $1^{\mathrm{a}}$ se completa, pois aí se entrelaçam os limites atribuídos ao júri e as limitações atribuídas aos jurados.

Dentre os mais radicalmente contrários ao júri, simpáticos portanto à sua extinção, existem os que, se remetendo à origem inglesa desse tribunal, afirmam, com todo o evolucionismo que tem direito, que o júri "exige, para seu aperfeiçoamento, indiscutível formação cultural, jurídica e moral, o que o torna inaplicável, pelo menos ainda, aos ibero-americanos",

Comparando leigos e técnicos, outros dizem que "a soma dos quesitos complexos que se apresenta nos julgamentos é de difícil compreensão para leigos, desafiando mesmo técnicos", ou seja, consideram os jurados alvos fáceis de" nocivas influências externas", ao passo que os juízes togados não o seriam.

Esse discurso da competência técnica surge das mais variadas formas: "não se compreende também, que numa era em que se reclama do próprio juiz criminal especialização, constituída não apenas do conhecimento do Direito Penal, mas também da Criminologia, da Penalogia etc., não se compreende - dizíamos - que se confie um

\footnotetext{
5 Limitações econômicas, segundo alguns, também teriam sido o entrave que determinou uma mudança substancial no alcance do júri norte-americano, neste século. Considera-se que há dois modelos principais de júri: o inglês e o norte-americano. Na Inglaterra, ele é contemplado, tanto na Magna Charta Libertarum quanto na Petition of Rights, como autêntico direito fundamental, tendo representado, à época de sua criação, uma repartição do poder de administrar a justiça entre reis e nobres, tanto que, há somente algumas décadas, foi abandonada, nesse país, a exigência de comprovação de propriedade imobiliária para cidadãos jurados. O júri norte-americano é proveniente desse modelo inglês, porém abandonou-o, pois a jurisprudência da Suprema Corte, desde 1937, não o reconheceu mais como direito fundamental e sim, tecnicamente, apenas como um privilégio dos acusados, que dele poderão ou não usufruir caso queiram. Assim a Suprema Corte decidiu, porque, apesar da Constituição americana estabelecer que todos os crimes devem ir à júri, não haveria condições econômicas e políticas para contemplar a totalidade dos os casos.
}

A ARROJO, Manuel Lopes-Rey - 1947 -Que es el Delito? Buenos Aires, pg. 215

${ }^{7}$ DUTRA, Mário Hoeppner - A Evoluçãa do Direito Penal e o Júri. Rio de Janeiro: Revista Forense, $249 / 54$ 
julgamento a homens que não possuem quaisquer desses conhecimentos, nem deles, talvez, tenham ouvido falar,8.

A idéia é a de que ninguém pode esperar do leigo decisão de "integral acerto e perfeita exação em assuntos que lhe são estranhos, especialmente quando homens hábeis e experimentados usam toda a sua argúcia e experiência para iludúlos", ou, em outras palavras, quando advogados e promotores, no júri, tudo fazem para induzir os jurados a superestimar detalhes de somenos importância, emprestando relevância a fatos secundários que beneficiam ou prejudicam o réu. "É impressionante", afirma o professor Heleno Cláudio Fragoso, "comparar a defesa que é feita perante o júri, com a que se faz ante o juiz togado. No júri todos os recursos são lícitos, desde que sirvam para convencer os jurados" um "auditório de interlocutores mudos a serem convencidos" e os advogados e promotores a "experts na arte da Oratória“, há quem, mesmo propondo novas técnicas que "respeitem a inteligência dos jurados" e sejam "ágeis como locuções de rádio", na verdade questionam a pertinência desse tribunal de leigos (PIMENTEL, fev/1988).

Enfim, os contrários à manutenção do Tribunal do Júri são unânimes em considerar que é um equívoco supor que o jurado possa decidir sobrepondo-se à lei, "apenas com seu senso comum". Concluem que não se pode conceber a existência do júri como decorrência da democracia ou como elemento de tutela da liberdade dos cidadãos. É corrente que, exceção feita à Inglaterra, o júri é instit uição em franca decadência em todos os países, devendo o Brasil acompanhar a tendência geral.

Afirma Magalhães Noronha: "Em outras eras, em que o juiz se curvava submisso ante o despotismo dos monarcas absolutistas, compreendia-se, talvez, sua necessidade. Mas hoje, em que o judiciário está provido de garantias que o põem a salvo de interferência de outro Poder, não se compreende a necessidade desse tribunal. Agora é ele, em regra, que se curva submisso aos ultimatos da política dominante, dos políticos e dos régulos nas comarcas do interior" (op. cit: 319 - grifos meus). E complementa Nelson Hungria: "Presentemente, o júri (nas suas linhas tradicionais) é uma velharia que só pode competir em novidade com as ordálias e os duelos judiciários ${ }^{10}$.

As respostas pró-júri, apontam todavia que, por meio dele, a Justiça toma contato "com a terra", penetrando o julgamento de considerações éticas, psicológicas, econô micas etc, permitindo que se introduza equidade nas decisões. $\mathrm{O}$ risco de que os julgamentos se percam no mundo dos Códigos e dos parágrafos, tornando-se o juiz togado um frio aplicador da lei, estaria assim garantido pela inserção dos jurados, que não conhecendo a lei, julgam com o seu senso comum, ajustando a norma ao caso concreto.

\section{III.1.b) Reformas?}

\footnotetext{
8 NORONHA, Magalhães - 1966 - Curso de Direito Processual Penal. São Paulo: Saraiva, pg.319

9 FRAGOSO, Heleno Cláudio - A Questão do Júri. Rio de Janeiro: Revista Forense, 193/26- 27.

10 HUNGRIA, Nels on - 1949 - Comentários ao Código Penal, v.I/49. Rio de Janeiro
} 
Toda esta polêmica ganhou nova força mediante a reforma do sistema penal brasileiro ora em andamento, na qual o Tribunal do Júri é tido, por muitos, como "uma das reais alternativas" de mudança (RAMOS, jan/1994: 283).

É consenso que o atual Código de Processo Penal - CPP, datado de 3/10/1941, apesar das muitas alterações que sofreu nesses últimos 50 anos, "tem-se mostrado ineficiente no combate ao incremento da criminalidade, porquanto dissociado dos novos valores sociais, políticos, econômicos e culturais" (idem). Em decorrência disto, formou-se uma comissão destinada a executar estudos para a elaboração de um anteprojeto de CPP, encaminhado à Câmara dos Deputados pelo Ministério da Justiça do Governo Itamar Franco.

Esta comissão, procurando aproveitar ao máximo as normas em vigor, propôs modificações somente àquelas consideradas necessárias à agilização e desburocratização do processo. As propostas de alteração, no que se refere ao processamento dos crimes da competência do Tribunal do Júri foram, basicamente: a eliminação do que se denominou "usinas de prescrição" (ante a exigência da intimação pessoal da sentença de pronúncia e impossibilidade do julgamento à revelia); a maior participação das partes nas fases de todo procedimento; a aplicação mais efetiva dos princípios da imediação e da verdade material; e a erradicação do excesso de formalismo, a fim de evitar nulidades (ibidem: 399/400).

De fato, dentre os que lutam para que o júri permaneça, se renove e até se amplie no Brasil, muitos reclamam, há tempos, do excessivo formalismo de seu procedimento, em especial no que se refere às nulidades. Também há descontentamento com os critérios de arregimentação dos jurados, com a complexidade do sistema de formulação do questionário a ser a esses submetido e com o sistema de votação e de pronunciamento do resultado pelos jurados.

No anteprojeto de CPP, mantém-se a divisão dos processos da competência do júri em duas fases: a de instrução, que se desenvolve unicamente perante o juiz togado, e a do júri, propriamente dito (art.406 - CPP). Pelo anteprojeto, portanto, o Conselho de Sentença continuará à margem das provas coligidas durante a instrução processual, sendo chamado apenas para o julgamento, ou seja, perduram as partes sem maiores chances de um conhecimento prévio mais apurado dos fatos. Quanto à pronúncia, que se constitui no "ato-condição", por parte do juiz togado, para que haja julgamento pelo Tribunal Popular, o anteprojeto propõe modificações substanciais, no sentido de que ela não seja fundamentada de tal modo que valha como uma pré-sentença condenatória. O mesmo se estende para a impronúncia, que se perder sua atual força de pré-sentença absolutória, deixará de exercer influência favorável ao réu, em caso de reabertura do processo por ocorrência de novas provas. Vários são os outros aspectos aparentemente técnicos que estão postos em discussão pelo anteprojeto, como o alistamento sorteio e convocação dos jurados.

A forma de recrutamento dos jurados não sofreu grandes críticas. $\mathrm{O}$ alistamento permanece sendo de 800 a 1500 em comarcas de mais de um milhão de habitantes, de 300 a 700 nas comarcas de mais de 100 mil e de 80 a 400 nas de menor população, com a publicação da $1^{\mathrm{a}}$ lista até 10 de novembro de cada ano, comportando alteração a requerimento de qualquer do povo ou de ofício e a publicação definitiva até 10 de dezembro. 


\section{III.1.c) Jurados}

Mas quais os critérios utilizados pelo juiz-presidente para alistar jurados?

Normalmente, o magistrado se vale, para compor a lista de nomes, os enviados pelo Cartório eleitoral (rol de cidadãos) ou os fornecidos por "autoridades locais", associações de classe, sindicatos profissionais, etc (art.439). O atual CPP (de 1941, portanto de 9 anos após o reconhecimento do direito de voto às mulheres), salvaguardou o direito-dever de ser jurado qualquer cidadão maior de 21 anos, isentou os maiores de 60 (art.434) e exigiu como requisito que sejam escolhidos os de notória idoneidade. Desde então, não há consenso doutrinário-jurisprudencial sobre o alcance deste termo.

Magalhães Noronha (op.cit: 244) propõe que não se entenda notoriedade como possuir diploma ou pertencer a determinada classe social, mas considera "indispensáveP" que, ao lado da "vida honesta", o jurado "possua o necessário descortino, para que possa compreender as questões (...) científicas que constituem objeto dos debates. Adriano Marrey, aduz que a idoneidade significa "aptidão", "capacidade tanto moral quanto intelectual" e, citando Borges Rosa, lembra que "os jurados devem ser os cidadãos mais notáveis do município por seus conhecimentos, experiência e elevação de caráter “'11.

Uma corrente minoritária, tida como a que pretende a "máxima democratização" da lista de jurados, propõe que, como a sociedade é composta por pessoas dos mais diferentes perfis, e sendo o júri o "julgamento do homem por seus pares", devem os jurados representar os mais diversos segmentos sociais. Mas seus críticos são contundentes e pregam a seleção cada vez mais rigorosa de jurados, tanto que o anteprojeto de CPP sugeriu instituições de ensino como novas fontes para fornecimento de nomes (SILVA Jr, out/95: 402). Escólomo da Nóbrega, contrário ao júri, pondera, neste sentido, que "não vale argumentar com o exemplo de Rio, São Paulo e outros grandes centros, onde (...)o júri apresenta apreciável nível de moralidade e eficiência", contando com "professores universitários, jur istas, médicos, engenheiros..."12.

Há os que tentam interpretar a notória idoneidade arriscando um meio termo: "o mecânico e o bancário, o estudante e o funcionário, todos de "notória idoneidade", não necessitam de formação acadêmica para bem julgarem e prolatarão, nesse contexto, a sentença que seja o ditame da vontade popular". Hélio Tornaghi, a propósito, aponta que "homens de carne e osso, têm de ser julgados de acordo com os padrões do meio em que vivem. Os anglo-americanos, têm sempre em consideração os standards de cada região, de cada grupo, de cada parcela do povo (BONFIM, jul/1993: 311-312).

A discussão vai longe, abordando, das mais diversas formas, os possíveis desdobramentos tanto de notoriedade quanto de idoneidade, passando por outros conceitos tão polêmicos quanto esses: inteligência, sensor intelectivo, imparcialidade, boa-fé, independência moral, busca abnegada da verdade, sabedoria, etc. Cabe lembrar que, contribui para este debate, o fato de que não basta os jurados serem indicados pela sorte, é preciso que sejam aceitos pela acusação e pela defesa, as quais

\footnotetext{
11 MARRE.Y, Adriano - Júri . São Paulo: Revista dos Tribunais, pg.54

12 in Revista Forense, 117/19
} 
podem recusar nomes. Quanto a isto, a opinião vigente é a de que ao fiscalizar a convocação indevida de jurados, salvaguarda-se a instituição. "Do contrário, em futuro breve, o Tribunal Popular, nesta época que vive da especialização técnica e do cientificismo, será recolhido (...) em um museu de história" (idem: 315 - grifos meus).

Muitos são os desdobramentos das duas principais questões que inicialmente enumeramos, não sendo possível, no momento, desenvolvê-los a contento, embora valha a pena brevemente mencioná-los, uma vez que, a nosso ver, de algum modo, eles se remetem a reflexões sobre democracia nas modernas sociedades de massa.

. Sala Secreta - Discute-se se os jurados devem ou não votar em "sala secreta", uma vez que a Constituição Federal dispõe que todos os julgamentos dos órgãos do Poder Judiciário serão públicos (art.93, IX). Alguns juristas são favoráveis à "sala", pois acreditam que, no caso do júri, sem ela não se garante a independência e imparcialidade das decisões dos jurados, pois, à mercê de pressões provocadas pela presença de parentes e amigos da vítima ou do réu, sem contar a da mídia, podem se sentir intimidados (MARREY, dez/1992). Outros, lembrando que o voto do jurado já foi oral e público, pregam o retorno da publicidade, embora resguardem o caráter secreto do voto. Os defensores dessa prática alegam que, experiências recentemente realizadas no Tribunal do Júri de Campo Grande - MT, revelaram a inocorrência de qualquer tipo de perturbação da ordem. Além disso, são pela possibilidade, hoje vedada, de que os jurados brasileiros possam se comunicar e discutir entre si suas opiniões a respeito do caso, pois "são condenados ao silêncio como se a íntima convicção gravitasse no universo do pecado e fosse incompatível com os princípios da investigação (...)" (DOTTI, mar/1992).

- Juiz Togado - Discussões sobre os limites da participação do juiz togado no julgamento pelo júri também são relevantes. Os mais receosos da participação de leigos acreditam que compete ao juiz togado, mais do que mediar o julgamento, propiciar "decisões inteligentes", submetendo jurados, advogados de defesa e promotores à sua capacidade de fazer com que os fatos sejam "inteira e completamente desenvolvidos". (BORENZTAJN, abr/1987).

Esta discussão já alcançou a problemática de se compete a jurados ou a magistrados decidirem sobre o caráter hediondo de certos crimes e se, nos casos de coautoria, quais os limites ló gicos para que se julgue diferentemente a participação de cada co-réu. Quanto à hediondez de delitos, isto nos leva, novamente, à questão do alargamento, manutenção ou restrição da competência do júri pois, por força de conexão, crimes como estupro, atentado violento ao pudor, latrocínio, extorsão com morte, extorsão mediante seqüestro, epidemia com morte e genocídio poderiam vir a ser atribuídos ao júri. Predomina a opinião de que compete ao juiz singular decidir sobre a hediondez do delito, uma vez que se trataria de interpretar a existência de uma qualificação legal (JESUS, jun/1995). Quanto à questão da co-autoria, há impasses, dividindo as opiniões entre a possibilidade dos jurados analisarem as chamadas circunstâncias objetivas e subjetivas envolvidas na atuação de cada agente ou disto ser tarefa exclusiva do magistrado (ROSA, dez/1993). 
- Soberania - Também ligadas a este debate, estão todas as questões referentes à soberania das decisões do júri (LUIZ, mai/1995), ou seja, se cabem recursos a elas, em que hipóteses podem ser reformadas (MALACHINI, mar/1992; SIQUEIRA \& Outros) e o problema de quando os veredictos não são unânimes (especialmente os que resultam de três votos a quatro) e podem ter decorrido de erro de algum dos jurados no momento de depositar sua cédula de "sim" ou "não" em resposta a algum dos quesitos (PINTO, dez/1991). A formulação destes pontos do questionário também é matéria de debate (BARBOSA, nov/1989; SOUZA, mai/1992 e PENTEADO, mai/1994).

. Quesitos - Não são poucos os preocupados com a implementação de mudanças nas técnicas e regras relativas à formulação dos quesitos que compõem o questionário a ser submetido ao júri, pois, de acordo com os preceitos atuais, são comuns ocorrências de nulidade decorrentes de questionários mal elaborados, o que implica o desperdício de julgamentos. Tourinho Filho está entre estes preocupados e assim se manifesta: "Se os jurados respondem monossilabicamente, é curial que os quesitos sejam formulados em proposições simples, de molde a lhes permitir a compreensão da pergunta e sem que haja possibilidade de impedir a real enunciação dos seus pensamentos,"13.

\section{Considerações Finais: Alguns Alinhavos}

Se retomarmos as questões lançadas no item II.1, veremos que estão entrelaçados os debates contemporâneos em torno do conceito de democracia e do júri, hoje, no Brasil.

Cabe refletirmos se o papel do júri se resume a regras de procedimento processual ou se ele é um espaço para que a sociedade civil tente produzir uma cidadania ativa.

A participação de leigos justamente no julgamento de crimes dolosos contra a vida será nefasta para a sociedade civil e/ou para o Estado?

Como pensar o recrutamento seletivo ou ampliado de jurados e como considerar seu papel e sua autonomia junto à "fala jurídica competente"?

Pode o júri brasileiro ser uma arena para o exercício de uma democracia participativa, mesmo não tendo os jurados sequer condições de dialogar entre si?

As questões são inúmeras, ainda mais se retomarmos os autores mencionados. Em todos eles encontramos pistas para pensar a apatia dos cidadãos frente aos problemas coletivos. A análise das lideranças, em Schumpeter, por exemplo, pode nos remeter à reflexões sobre as correntes jurídico-políticas que atravessam o Direito brasileiro e o fazem ser, quem sabe, um conjunto de facções que se toleram.

Cada um dos autores, certamente, nos lança uma ou várias possibilidades de investigação. Esperamos poder aproveitá-las, numa próxima oportunidade, uma vez que este é apenas um primeiro esforço de reflexão.

Uma idéia, referente à atual reforma da legislação penal, nos parece importante para alinhavar nossas reflexões:

\footnotetext{
$\overline{13}$ TOURINHO Filho, Fernando Costa - 1979 - Processo Penal. Bauru: Javoli, $4^{\text {o vol-pg.94 }}$
} 
"Se o objetivo da reforma é, conforme se percebe pelas conferências e trabalhos dos ilustres integrantes da comissão, como René Dotti, retornar a um Direito Criminal cada vez mais coincidente com o mínimo ético e, ao mesmo tempo, adequado às necessidades sociais, a ampliação da competência do júri, juntamente com sua simplificação, desempenharia um importante papel político. (...)para que tenha sucesso, será necessário que a reforma penal procure, antes de soluções mirabolantes, o aperfeiçoamento democrático dos instrumentos que já possui. Se não garante o sucesso da reforma, o Tribunal do Júri possui, ao menos, a virtude de possibilitar a busca desse sucesso - que será sempre incessante - em parceria com a sociedade." (RAMOS, jan/1994: 287) 


\section{Bibliografia}

V.1. Alguns dos Textos Adotados na Disciplina "Democracia, Política e Sociedade: Teorias X Realidades” (FLS 898), $1^{\circ}$ Semestre/1996

. ARENDT, Hannah

1989 - A Condição Humana. Rio de Janeiro: Forense Universitária (Introdução, caps. 1 e 2: I-XII e 9-88)

. BOBBIO, Norberto

1983 - Qual Socialismo? Rio de Janeiro: Paz e Terra.

1986 - O Futuro da Democracia. Rio de Janeiro: Paz e Terra.

1988 - Estado, Governo e Sociedade. Para uma Teoria Geral da Política. Rio de Janeiro: Paz e Terra (cap.4: 135-165)

1995 - Direita e Esquerda. São Paulo: Unesp

. DAHL, Robert

1989 - Democracy and its Limits. London: Yale University Press, New Haven \& London (cap.15-23)

. HIRST, Paul

1993 - A Democracia Representativa e seus Limites. Rio de Janeiro: Zahar (cap.3: 47-66)

. MACPHERSON, C. B.

1978 - A Democracia Liberal. Rio de Janeiro: Zahar

. MARTINS, Carlos Estevam

1994 - O Circuito do Poder: Democracia, Participação, Descentralização. São

Paulo: Entrelinhas (Introdução, caps. 1, 2 e 8: 1-15, 19-97 e 177-211)

. SARTORI, Giovanni

1994 - A Teoria da Democracia Revisitada, vol. 1. São Paulo: Ática (Introdução, caps.1, 5 e 8: 9-39, 123-180, 286-336)

. SCHUMPETER, Joseph

1971 - Capitalismo, Socialismo e Democracia. Rio de Janeiro, Zahar (caps. 2023: 295-376)

. TOURAINE, Alain

1994 - Qu'est-ce que la Democracie ? Paris: Fayard. (1 $1^{\text {a }}$ parte,caps.1-5: 17109; $2^{\mathrm{a}}$ parte, cap.2: 196-215; $4^{\mathrm{a}}$ parte, cap.1: 220-234 e Conclusão: 261-277) 


\section{V.2. Textos Doutrinário-Criminais sobre o Tribunal do Júri no Brasil ${ }^{14}$}

- BARBOSA, Marcos Elias de Freitas (Desembargador do TJMG)

nov/1989 - Regras e Quesitos do Júri ante o Código Penal de 1984.

RT:649/223-244

. BONFIM, Edílson Mougenot (Promotor de Justiça do Estado de São Paulo, oficiando perante o Tribunal do Júri de Diadema/SP em 1992 e no $1^{0}$ Tribunal do Júri de São Paulo/SP em 1993)

set/1992 - Júri de Homicídio, um Desafio: em Defesa da Exemplaridade da

Pena; contra a Falácia da Criminologia Radical. RT:683/267-276

jul/1993 - O Selecionamento dos Jurados, a Questão da "Notória Idoneidade"

e a Boa Formação do Conselho de Sentença no Tribunal do Júri . RT:693/309-316

- BORENSTZAJN, David (Promotor de Justiça no Rio de Janeiro) abr/1987 - A Busca da Verdade no Tribunal do Júri . RT:618/420-423

- DOTTI, René Ariel (Advogado e Professor Titular da Universidade Federal do Paraná. Membro do Conselho Diretor do Instituto Latino Americano das Nações Unidas para Prevenção do Delito e Tratamento do Delinqüente) mar/1992 - A Publicidade dos Julgamentos e a "Sala Secreta" do Júri. RT:677/330-337

- JESUS, Damásio E. de (Conselheiro do Conselho Nacional de Política Criminal e Penitenciária) jun/1995 - Homicídio, Crime Hediondo e Júri. RT:716/400-402

. LUIZ, Gilberto Antonio (Advogado Criminal em Santa Fé do Sul/SP) mai/1995 - A Soberania dos Veredictos (Art. 5o, XXXVIII, da CF). RT:715/568-571

- MALACHINI, Edson Ribas (Prof. Assist. de Direito Processual Civil na Universidade Federal do Paraná, Juiz de Direito em Curitiba, convocado para a $2^{a}$ Câmara Criminal do Tribunal de Justiça do Estado) mar/1992 - Desclassificação do Crime pelo Tribunal do Júri e Interrupção da Prescrição pela Pronúncia. RT:677/309-316

- MARREY, Adriano (Desembargador do Tribunal de Justiça do Estado de São Paulo. Aposentado) dez/1992 - A Publicidade dos Julgamentos e a "Sala Secreta" no Júri. RT:686/277-279

\footnotetext{
14 Estes textos representam a totalidade dos que se referem a Tribunal do Júri e se encontram nos volumes da Revista dos Tribunais editados entre 1987 e 1995. Citaremos a revista apenas pela sigla $\boldsymbol{R T}$, seguida do $\mathrm{n}^{\mathrm{O}}$ do volume e das páginas em que se localizam os artigos. Ela é editada pela Editora Revista dos Tribunais, São Paulo.
} 
. PENTEADO, Jaques de Camargo (Procurador de Justiça e pesquisador do Centro de Extensão Universitária)

mai/1994 - Júri: Legítima Defesa Putativa e Questionário. RT:703/414-417

. PIMENTEL, Manoel Pedro (Catedrático de Direito Penal na Faculdade de Direito da Universidade de São Paulo)

fev/1988 - A Oratória perante o Júri. RT:628/281-290

- PINTO, Antônio Carlos de Carvalho (Advogado Criminalista em São Paulo. Professor de Direito Processual Penal nas Faculdades Metropolitanas Unidas) dez/1991 - Júri Popular: Erro de Jurado. O Amargo Quatro a Três. RT:674/370

- RAMOS, João Gualberto Garcez (Procurador da República, Prof. Auxiliar e Mestrando da UFPR)

jan/1994 - O Júri como Instrumento de Efetividade da Reforma Penal. RT:699/283-288

- ROSA, Antônio José M. Feu (Desembargador do Tribunal de Justiça do Espírito Santo)

dez/1993 - A Co-autoria no Júri . RT:698/279-283

. SILVA Jr, Walter Nunes da (Juiz Federal e Professor da Universidade Federal do Rio Grande do Norte)

out/1995 - Tribunal do Júri e as Modificações Propostas. RT:720/399-406

- SIQUEIRA, Geraldo Batista (Procurador de Justiça. Prof. de Direito Penal e processual Penal), MARTINS, Reynaldo Edreira (Procurador de Justiça) e SIQUEIRA, Marina da Silva (Promotora de Justiça) jun/1988 - Sucumbência Parcial no Julgamento do Júri. RT:632/265

.SOUZA, Aélio Paropat (Magistrado, Doutor em Direito pela UFMG, Prof. de Direito Sumular da UNIUBE-MG) mai/1992 - Quesitos do Júri no Direito Sumular. RT:679/283

.STOCO, Rui (Juiz da $1^{\text {a }}$ Vara da Fazenda Pública) fev/1991 - Crise Existencial do Júri no Direito Brasileiro. RT:664/250-252 


\section{V.3. Legislação}

. DELMANTO, Celso

1988 - Código Penal Comentado. Rio de Janeiro: Renovar ( $2^{\mathrm{a}}$ ed.)

. JESUS, Damásio E. de

1989 - Código de Processo Penal Anotado. São Paulo: Saraiva ( $\left.7^{\mathrm{a}} \mathrm{ed}.\right)$

. LOPES, Maurício Antônio Ribeiro (coord.) e vários colaboradores

1996 - Constituição da República Federativa do Brasil (CF/88). São Paulo:

Editora Revista dos Tribunais 


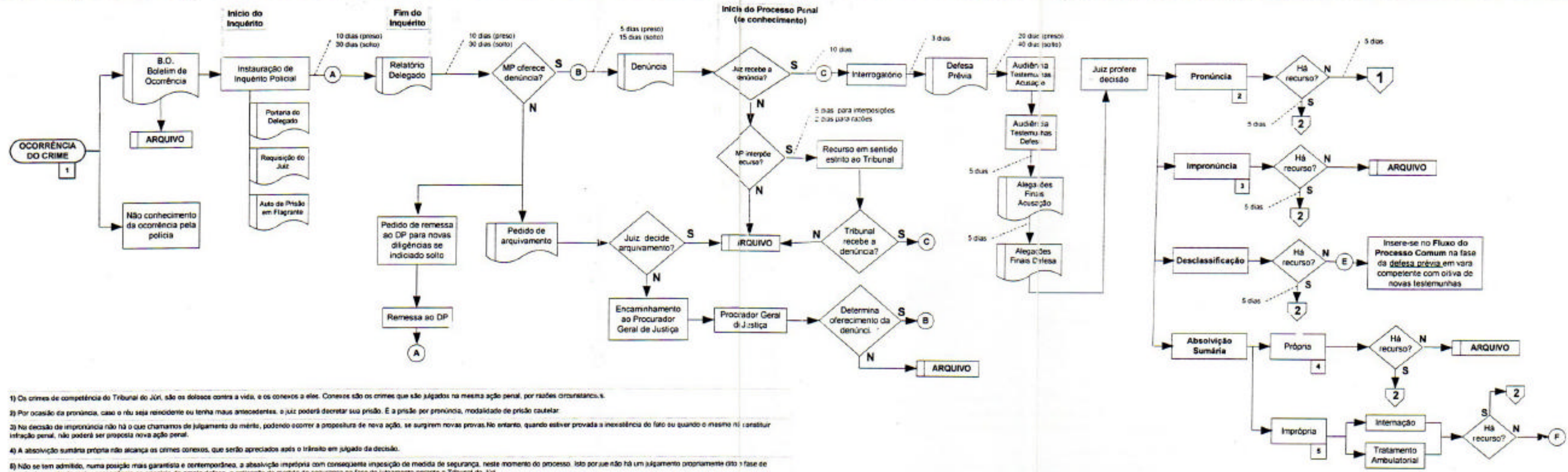

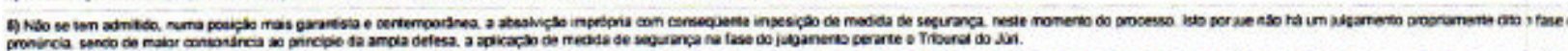

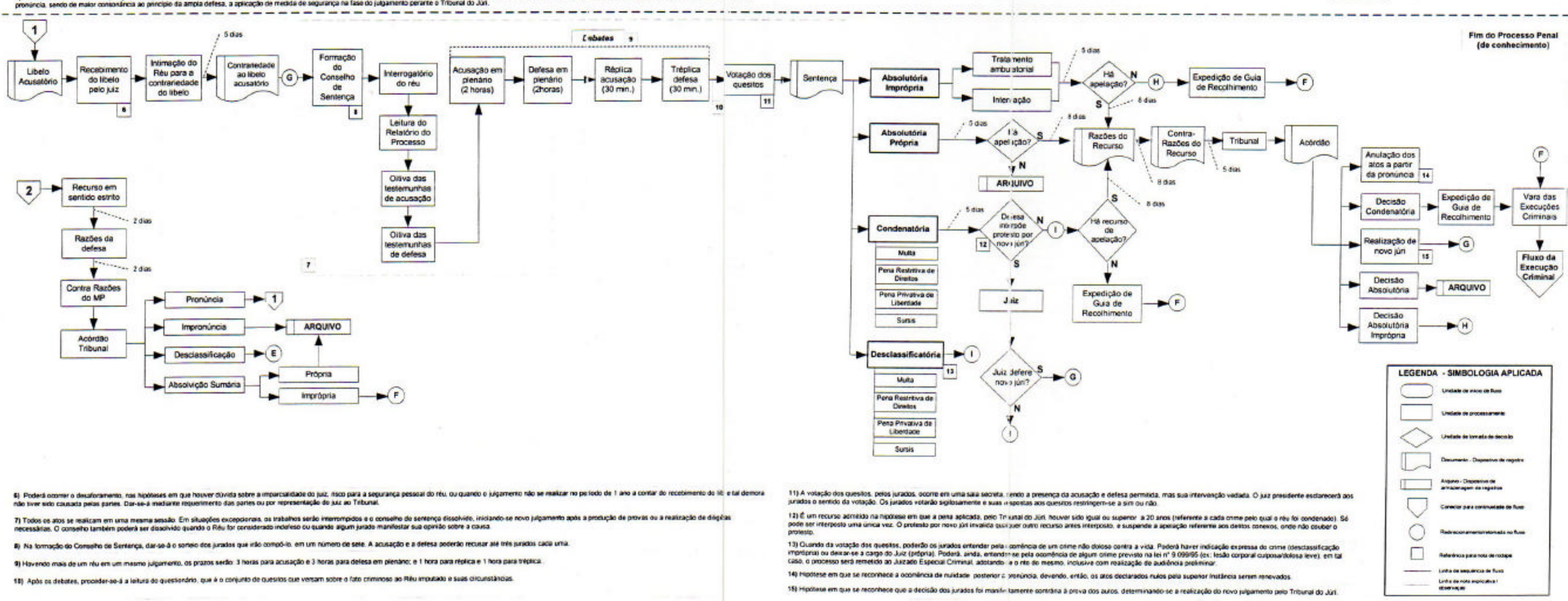

in

Convênio FSEADE - IBCCRIM 


\begin{tabular}{|ll|}
\hline PODER JUDICIÁRIO & Comarca : \\
& Cartório do_ Tribunal do Júri \\
& Ref. Tribunal do Júri \\
\hline Relação $n^{\circ}$ Ordom ${ }^{\circ}$
\end{tabular}

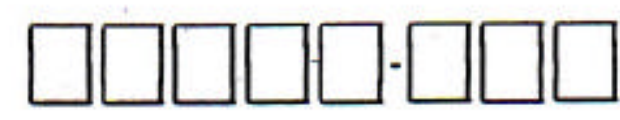

\section{CARTA dE CONVOCAÇĀo DE JURADO}

Tenho a honra de comunicar que, nesta data, Vossa Senhoria foi sorteado(a) para servir como Jurado(a) deste Egrógio Tribunal, a partir do dia de de 199 até ser dispensado(a), de acordo com a lei.

A sessảo, na data acima, terá inicio às horas, ficando Vossa Senhoria, por força de lei, no correr do periodo em que estiver convocado(a), desobrigado(a) de qualquer outra atividade funcional, sem prejulzo de salários e outras vantagens.

Conhecendo o devotamento de Vossa Senhoria para assuntos desta natureza, estou certo do seu comparecimento no dia e hora aprazados, no Fórum desta comarca, sito

\section{Saudações.}

$\mathrm{Em}$ de de 199

Juiz(a) Presidente

$\begin{array}{lll} & \text { 1. Apresentar esta Carta no dia da audiencia. } \\ \text { Observaçio: } & \text { 2. Apresentar-se convenientemente trajado(a). }\end{array}$

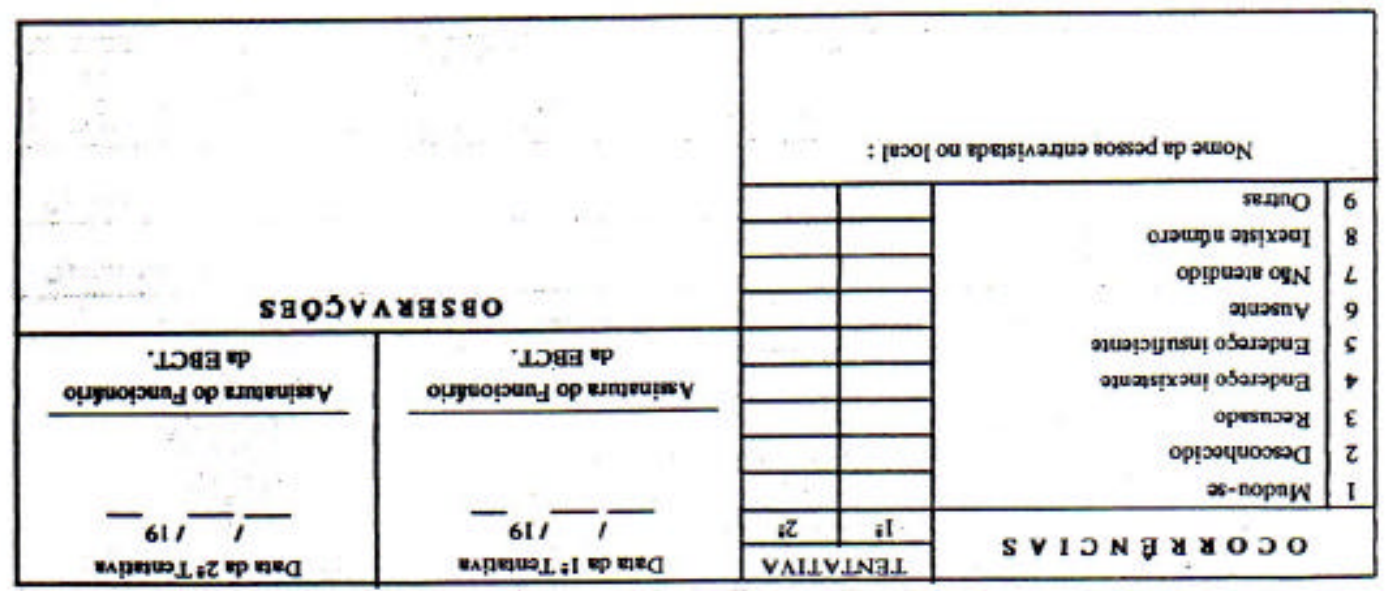


TOTAIS MENSAIS - 1995

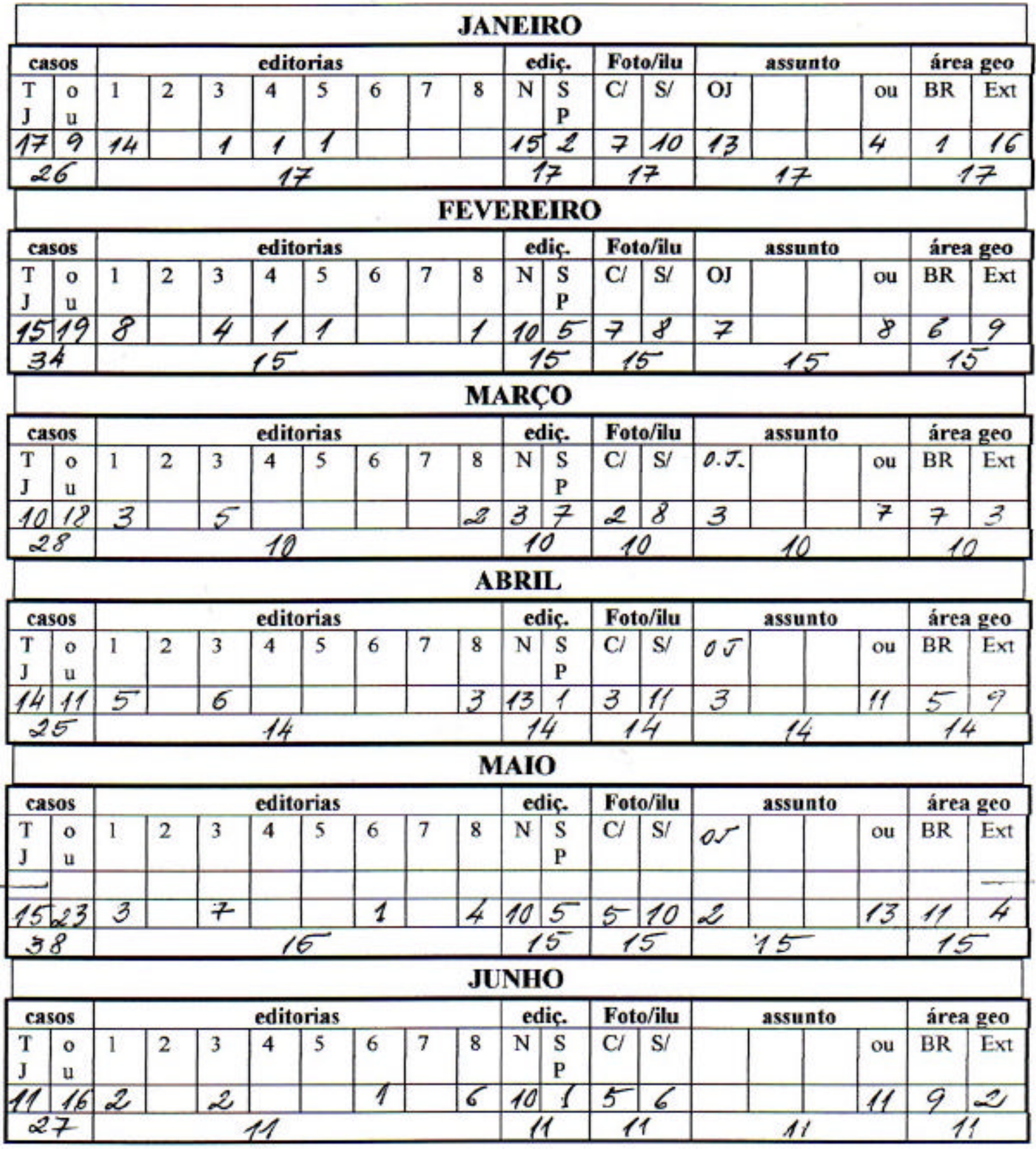

LEGENAR:

- casos f TJ = SOBRE TRIBUARL AO JURI

OU = SOORE OUTROS TRIBUnAISf JiRTS (DE PREMIOS ARTISTICD, DEX.)

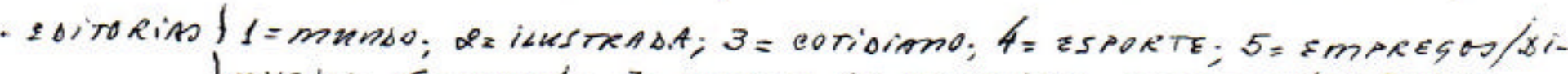

InHEIRO; $6=$ MAIS!; 7 = REVISTA $\triangle A$ FOLHALdAD. ESTSCIAL/TV FOLHA; $8=$ DRASIL/ODinitio /19 DAGIIAA.

ESISAO $J N=$ nAcionnL

SSP = PALLISTARA

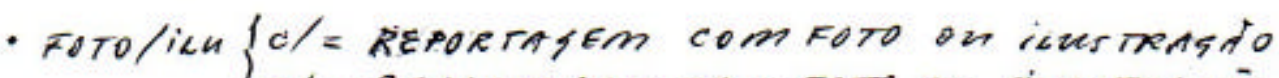

$5 \%$ REPARTASEM SEM FOTO OU TLUSTCASAD

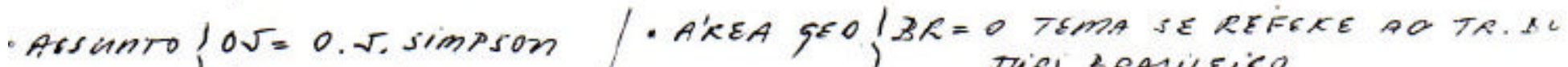
I on $=$ outeos

TURI BRASILEIKO 


\begin{tabular}{|c|c|c|c|c|c|c|c|c|c|c|c|c|c|c|c|c|c|c|c|}
\hline \multicolumn{20}{|c|}{ JULHO } \\
\hline \multicolumn{2}{|c|}{ casos } & \multicolumn{8}{|c|}{ editorias } & \multicolumn{2}{|c|}{ edif. } & \multicolumn{2}{|c|}{\begin{tabular}{|l|} 
Foto/ilu \\
\end{tabular}} & \multicolumn{4}{|c|}{ assunto } & \multicolumn{2}{|c|}{ área geo } \\
\hline $\begin{array}{l}\mathrm{T} \\
\mathrm{J}\end{array}$ & $\begin{array}{l} \\
\mathrm{u} \\
\end{array}$ & 1 & 2 & 3 & 4 & 5 & 6 & 7 & 8 & $\mathrm{~N}$ & $\begin{array}{l}\mathrm{S} \\
\mathrm{P}\end{array}$ & $\mathrm{Cl}$ & S/ & & & V.g & ou & BR & Ext \\
\hline 14 & 11 & 5 & & 7 & & & & & 2 & \multirow{2}{*}{\multicolumn{2}{|c|}{14}} & 8 & 6 & & & 5 & 9 & 9 & 5 \\
\hline \multicolumn{2}{|c|}{25} & \multicolumn{8}{|c|}{14} & & & 1 & & \multicolumn{4}{|c|}{14} & \multicolumn{2}{|c|}{14} \\
\hline \multicolumn{20}{|c|}{ AGOSTO } \\
\hline \multicolumn{2}{|c|}{ casos } & \multicolumn{8}{|c|}{ editorias } & \multicolumn{2}{|c|}{ ediç. } & \multicolumn{2}{|c|}{ Foto/ilu } & \multicolumn{4}{|c|}{ assunto } & \multicolumn{2}{|c|}{ área geo } \\
\hline \begin{tabular}{l|}
$\mathrm{T}$ \\
$\mathrm{J}$
\end{tabular} & \begin{tabular}{|l}
0 \\
$\mathrm{u}$
\end{tabular} & 1 & 2 & 3 & 4 & 5 & 6 & 7 & 8 & $\mathrm{~N}$ & $\begin{array}{l}\mathrm{S} \\
\mathrm{P}\end{array}$ & $\mathrm{Cl}$ & S/ & $0 . \pi$ & 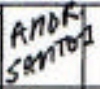 & & ou & BR & Ext \\
\hline \multirow{2}{*}{\multicolumn{2}{|c|}{\begin{tabular}{|c|c|}
33 & 18 \\
51 \\
\end{tabular}}} & 16 & & 13 & 1 & & & 1 & 2 & \multirow{2}{*}{\multicolumn{2}{|c|}{$\frac{246}{33}$}} & & 25 & 7 & 8 & & 18 & 16 & 17 \\
\hline & & \multicolumn{8}{|c|}{33} & & & 3 & 3 & & 33 & & & 3 & 3 \\
\hline & & & & & & & & & ETE & EMB & RO & & & & & & & & \\
\hline cas & & & & & edito & rias & & & & $\overline{\text { edi }}$ & & Fots & o/ilu & & assun & & & área & geo \\
\hline $\begin{array}{l}\mathrm{T} \\
\mathrm{J}\end{array}$ & $\begin{array}{l}o \\
\text { u }\end{array}$ & 1 & 2 & 3 & 4 & 5 & 6 & 7 & 8 & $\mathrm{~N}$ & $\begin{array}{l}\mathrm{S} \\
\mathrm{P}\end{array}$ & $\mathrm{Cl}$ & $\mathrm{S} /$ & 0.5 & & & ou & BR & Ext \\
\hline 23 & 9 & 15 & 1 & 2 & & 1 & & 1 & 3 & 21 & 2 & 8 & 15 & 13 & & & 10 & $\sigma$ & 17 \\
\hline 3. & & & & & 2.3 & & & & & 2 & & 2 & 2.3 & & 23 & & & & 30 \\
\hline & & & & & & & & & OUT & UBI & RO & & & & & & & & \\
\hline cas & & & & & edito & rias & & & & edi & & Fote & o/ilu & & assun & & & área & geo \\
\hline \begin{tabular}{l|}
$\mathrm{T}$ \\
$\mathrm{J}$
\end{tabular} & $\begin{array}{l}0 \\
\text { u }\end{array}$ & 1 & 2 & 3 & 4 & 5 & 6 & 7 & 8 & $\mathrm{~N}$ & $\begin{array}{l}\mathrm{S} \\
\mathrm{P}\end{array}$ & $\mathrm{Cl}$ & S/ & 0.5 & & & ou & $\mathrm{BR}$ & Ext \\
\hline 6.1 & 14 & 32 & 1 & 14 & 1 & & 4 & 1 & 8 & 51 & 10 & 18 & 43 & 31 & & & 30 & 17 & 44 \\
\hline 8 & & & & & 61 & & & & & 61 & & & 6 & & 61 & & & 6 & $\angle$ \\
\hline & & & & & & & & & OVI & EME & BRC & & & & & & & & \\
\hline cas & & & & & edito & rias & & & & edi & & Fot & o/ilu & & assun & & & área & geo \\
\hline \begin{tabular}{l|l}
$\mathrm{T}$ \\
$\mathrm{J}$
\end{tabular} & $\begin{array}{l}0 \\
\text { u }\end{array}$ & 1 & 2 & 3 & 4 & 5 & 6 & 7 & 8 & $\mathrm{~N}$ & $\begin{array}{l}\mathrm{S} \\
\mathrm{P}\end{array}$ & $\mathrm{C} / \mathrm{d}$ & S/ & & & & ou & BR & Ext \\
\hline 15 & 21 & 5 & & 7 & & & & & 3 & 7 & 8 & 2 & 13 & & & & 15 & 10 & 5 \\
\hline 3 & & & & & 15 & & & & & 15 & & 15 & 5 & & 15 & & & & 5 \\
\hline & & & & & & & & & EZE & $\mathrm{MB}$ & RO & & & & & & & & \\
\hline cas & & & & & edito & rias & & & & edi & & Foto & o/ilu & & assun & & & área & geo \\
\hline $\begin{array}{l}\mathrm{T} \\
\mathrm{J}\end{array}$ & \begin{tabular}{|l|}
$o$ \\
u
\end{tabular} & 1 & 2 & 3 & 4 & 5 & 6 & 7 & 8 & $\mathrm{~N}$ & $\begin{array}{l}\mathrm{S} \\
\mathrm{P}\end{array}$ & $\mathrm{Cl}$ & S/ & 0.5 & & & ou & BR & Ext \\
\hline 9 & 13 & 2 & & 4 & & & & & 3 & 7 & 2 & 4 & 5 & 1 & & & 8 & 6 & 3 \\
\hline 2 & & & & & 9 & & & & & 9 & & 9 & & & 9 & & & & 2 \\
\hline & & & & & & & & DA & G & ERA & IL - & 199 & & & & & & & \\
\hline cas & & & & & edito & rias & & & & edi & & Foto & o/ilu & & assun & & & área & geo \\
\hline \begin{tabular}{l|}
$\mathrm{T}$ \\
$\mathrm{J}$
\end{tabular} & $\begin{array}{l}0 \\
\mathrm{u} \\
\end{array}$ & 1 & 2 & 3 & 4 & 5 & 6 & 7 & 8 & $\mathrm{~N}$ & $\begin{array}{l}\mathrm{S} \\
\mathrm{P}\end{array}$ & $\mathrm{Cl}$ & S/ & OJ & & & ou & BR & Ext \\
\hline 237 & 187 & 110 & 2 & 72 & 4 & 3 & 6 & 3 & 37 & & 5.0 & 77 & 160 & 80 & & & 57 & 103 & 134 \\
\hline 42 & & & & & 237 & & & & & 23 & & 23 & & & 23 & 37 & & $2=$ & 37 \\
\hline
\end{tabular}

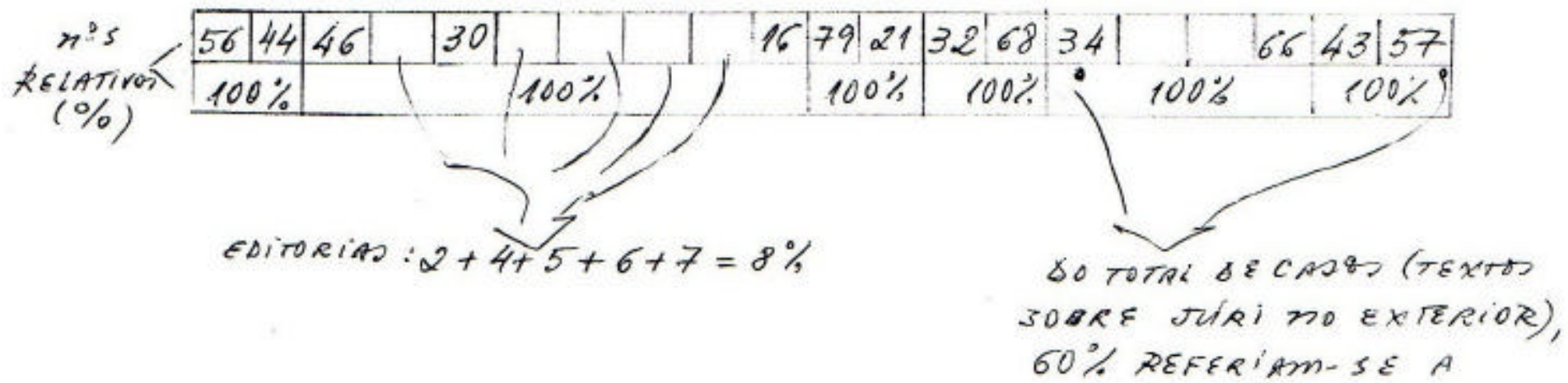




\section{FOLHA DE S. PAULO - JÚRI}

\section{JANEIRO - 1995}

\begin{tabular}{|c|c|c|c|c|c|c|c|c|}
\hline C. & dia & editoria & edição & pág & $\begin{array}{l}\text { foto/ } \\
\text { ilustr. }\end{array}$ & $\begin{array}{c}\text { Tipo de } \\
\text { art. }\end{array}$ & assunto principal & $\begin{array}{c}\text { área } \\
\text { geogr. }\end{array}$ \\
\hline 1 & 31 & ilostr. & nAc & & & & $H Q-I T A L I A M Q$ & ITPLi IA \\
\hline 2 & 30 & ESPORTE & $S P$ & & & & FUTEBOL-SA & $5 P$ \\
\hline (3) & 29 & smaxest & nqc. & $7-3$ & $I$ & & TRIB. TRABALH/AS & G. BRET. \\
\hline 4 & 28 & izuestR. & $n A C$ & & . & & GDE PREMIO-ARQUITET. & PARIS \\
\hline & 27 & manso & nAc. & $2-11$ & 一 & & cAso 0.J. simpston & $E U A$ \\
\hline & 26 & ESPARTE & nAO. & $2-12$ & $F$ & & $\prime$ & $"$ \\
\hline & 25 & munoo & $n A C$ & $2-12$ & $I$ & & $\prime \prime$ & 1. \\
\hline (8) & 24 & $"$ & " & 2.10 & $F$ & & $n$ & " \\
\hline & 24 & 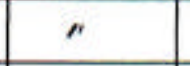 & $"$ & 2.10 & $F$ & & $"$ & " \\
\hline (10) & 23 & " & $n$ & $2 \cdot 8$ & 一 & & $n$ & " \\
\hline (11) & 23 & " & $\prime$ & $2=8$ & - & & " & er \\
\hline (12) & 20 & " & $"$ & 2.9 & - & & " & " \\
\hline (13) & 19 & $n$ & $S P$ & 2.4 & 一 & & $"$ & " \\
\hline (14) & 18 & " & nac & 2.4 & 一 & & ' & $n$ \\
\hline (15) & 17 & consiano & $S P$ & 3.5 & 一 & & $\begin{aligned} \text { RACHAO } & \text { FonIRAR PEMAL } \\
& =\text { TEnT DE HOMIC. }\end{aligned}$ & $5 P$ \\
\hline 16 & 17 & $i \angle U S \pi R$ & nAC. & & & & 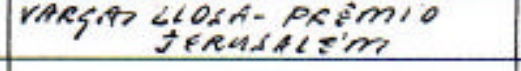 & PERU \\
\hline (17) & 14 & $m 21 n \Delta 0$ & $n A c$. & 2.6 & $F$ & & $\cos 0$ 0.J. simpson & $E U P$ \\
\hline 18 & 11 & iLusth. & nte. & & & & 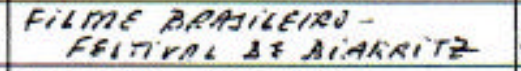 & FRAms.9 \\
\hline (19) & 10 & murso & nas & 2.9 & $F$ & & $\begin{array}{l}\text { PROCESSO-EXALOSAOU } \\
\text { MORLA TRADF CEVTER }\end{array}$ & $\varepsilon$ UIA \\
\hline (20) & 10 & $\prime \prime$ & $"$ & 2.9 & $F$ & & chso 0. $\sqrt{ }$. Simpson & $\varepsilon G A^{\prime}$ \\
\hline 21 & 10 & $\cos \theta$ & nac. & & & & 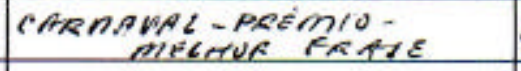 & GUARUJA \\
\hline (22) & 09 & munso & nac. & 2.8 & - & & $0 . \pi$ & $\sum U A_{1}$ \\
\hline 23 & 09 & itustr. & nAc & & & & 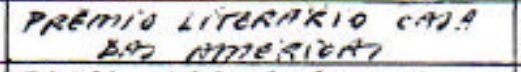 & $C A B A$ \\
\hline 24 & 08 & mais! & nAc. & & & & 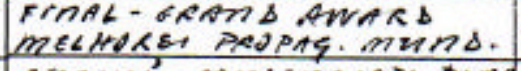 & nyc \\
\hline (25) & 05 & invinso & nac. & 2.10 & - & & 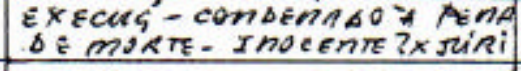 & TEXAS \\
\hline 26 & 01 & REV, FOCHA & nac & & & & 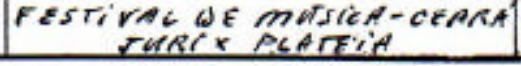 & CEARA' \\
\hline
\end{tabular}


